\title{
DETAILED STUDY OF WATER QUALITY, BOTTOM SEDIMENT, AND BIOTA ASSOCIATED WITH IRRIGATION DRAINAGE IN THE SALTON SEA AREA, CALIFORNIA, 1988-90
}

By James G. Setmire, Roy A. Schroeder, and Jill N. Densmore U.S. GEOLOGICAL SURVEY and

Steven L. Goodbred, Daniel J. Audet, and William R. Radke U.S. FISH AND WILDLIFE SERVICE

U.S. GEOLOGICAL SURVEY

Water-Resources Investigations Report 93-4014

U.S. GEOLOGICAL SURVEY

U.S. FISH AND WILDLIFE SERVICE

U.S. BUREAU OF RECLAMATION

U.S. BUREAU OF INDIAN AFFAIRS

Prepared in cooperation with the

CÁLIFORNIA REGIONAL WATER QUALITY CONTROL BOARD, COLORADO RIVER BASIN REGION 


\section{U.S. DEPARTMENT OF THE INTERIOR BRUCE BABBITT, Secretary}

U.S. GEOLOGICAL SURVEY

ROBERT M. HIRSCH, Acting Director

Any use of trade, product, or firm names in this publication is for descriptive purposes only and does not imply endorsement by the U.S. Government.

For sale by the U.S. Geological Survey

Earth Science Information Center

Open-File Reports Section

Box 25286, MS 517

Denver Federal Center

Denver, CO 80225

For additional information write to:

District Chief

U.S. Geological Survey

Federal Building, Room W-2233

2800 Cottage Way

Sacramento, CA 95825 


\section{CONTENTS}

Abstract 1
Introduction 2
Background 2
Acknowledgments 2
Purpose and scope 2
Description of study area 3
Ecology of Salton Sea area 4
Previous investigations 13
Considerations in developing a sampling strategy 15

Sample collection and analysis $\mathbf{1 6}$

Selection of sampling sites 16

Water and bottom sediment 16

Biota 20

Sampling methods 23

Water and bottom sediment 23

Biota 24

Analytical methods 27

Water and bottom sediment 27

Biota 28

Areal distribution of selected constituents 29

Temporal variation in concentration of selected constituents $\mathbf{3 0}$

Processes controlling the concentration of selenium and other constituents

40

Subsurface drainwater $\mathbf{4 0}$

Physical characteristics of fields

40

Evaporative concentration $\mathbf{4 1}$

Selenium 43

Boron 47

Interaction of subsurface drainwater and shallow ground water 47

Movement and partitioning of selenium in the Salton Sea 54

Effects of selenium and other constituents on biota 56

Selenium 56

Aquatic vegetation 57

Aquatic invertebrates $\mathbf{5 7}$

Fish 60

Amphibians and reptiles 60

Birds 61

Food-chain relations 64

Boron 64

Aquatic vegetation 67

Aquatic invertebrates 68

Fish 68

Amphibians and reptiles 68

Birds 69

Food-chain relations $\mathbf{7 1}$

Organochlorine pesticides $\mathbf{7 3}$

DDT and metabolites $\mathbf{7 3}$

Aquatic invertebrates $\mathbf{7 3}$

Fish 76

Amphibians and reptiles 


\section{Birds 78}

Food-chain relations 83

Other organochlorine pesticides $\mathbf{8 5}$

Assessment of susceptibility of birds to contaminant effects 87

Summary and conclusions 93

Selected references 95

\section{FIGURES}

1. Map showing location of study area 3

2,3. Photographs showing:

2. Water birds feeding on pileworms and waterboatmen at the south end of the Salton Sea 4

3. Abandoned colonial bird nests at the south end of the Salton Sea 5

4,5. Diagrams showing trophic and bioaccumulation relations among organisms of:

4. The Salton Sea 6

5. Rivers and drains in the Imperial Valley $\mathbf{8}$

6,7. Photographs showing:

6. Numerous species of water birds in shallow-water habitat of the Salton Sea $\mathbf{1 2}$

7. Dowitchers feeding on invertebrates at the south end of the Salton Sea 13

8. Diagram showing selenium cycle in the Salton Sea 16

9,10. Maps showing:

9. Subsurface-drainwater and surface-water sampling sites in the study area $\mathbf{1 7}$

10. Biological sampling sites in the study area $\mathbf{2 1}$

11. Regression plot of 1988 and 1986 selenium concentrations in subsurface-drainwater samples collected in the Imperial Valley $\mathbf{3 0}$

12,13. Maps showing areal distribution of concentrations of selected constituents in subsurface-drainwater samples collected in the Imperial Valley, May 1988:

12. Selenium 31

13. Dissolved solids 32

14-16. Graphs showing:

14. Temporal variation in instantaneous discharge and in concentrations of selected constituents in subsurface-drainwater samples from 15 fields in the Imperial Valley, May 1988 and August 1988-August 198933

15. Daily mean discharge in the Alamo River near Niland and the New River at outlet, near Westmorland, August 1988-August 198939

16. Contribution of trench flow to subsurface drainflow $\mathbf{4 0}$

17. Schematic showing movement of water and layout of subsurface drains, and configuration of soilsampling sites, in a typical field in the Imperial Valley $\mathbf{4 2}$

18-20. Regression plots for subsurface-drainwater samples collected in the Imperial Valley, May 1988:

18. Hydrogen- and oxygen-isotope ratios and global meteoric water line 43

19. Hydrogen-isotope ratio and chloride concentration 44

20. Selenium and chloride concentrations 45

21. Graph showing selenium-to-chloride ratios in subsurface-drainwater samples collected at 108 sites in the Imperial Valley, May 198845

22,23. Regression plots for subsurface-drainwater samples collected in the Imperial Valley, May 1988:

22. Log base 10 boron and chloride concentrations 46

23. Log base 10 boron and dissolved-solids concentrations 46

24-29. Graphs showing:

24. Hydrogen- and oxygen-isotope ratios and global meteoric water line for water samples from wells and lysimeters at three sites in the Imperial Valley $\mathbf{4 8}$

25. Concentrations of selected constituents, in relation to depth, for water samples collected from wells and lysimeters at the northern site (site 8) in the Imperial Valley 49

26. Concentrations of selected constituents, in relation to depth, for water samples collected from wells and lysimeters at the middle site (site 50) in the Imperial Valley $\mathbf{5 0}$ 
27. Concentration of tritium in water samples from lysimeters and wells at three sites in the Imperial Valley $\mathbf{5 1}$

28. Concentrations of selected constituents, in relation to depth, for water samples from wells and lysimeters at the southern site (site 98) in the Imperial Valley $\mathbf{5 2}$

29. Concentration of tritium in water samples from the Colorado River, 1977-88 $\mathbf{5 3}$

30. Aerial photograph showing areal distribution of selenium in bottom sediment in the delta area of the

Alamo River at the southern end of the Salton Sea, August $1988 \mathbf{5 5}$

31-45. Graphs showing:

31. Bioaccumulation of selenium in transplanted Asiatic river clams, 1989-90 60

32. Concentration of selenium, and probability of embryotoxicity, in black-necked stilt eggs from the Salton Sea, 1988-8963

33. Concentration of selenium in food-chain organisms of the Salton Sea, 1988-90, and dietary thresholds for water birds 65

34. Concentration of selenium in food-chain organisms of rivers and drains in the Imperial Valley, 1988-90, and dietary thresholds for water birds 65

35. Bioaccumulation of boron in transplanted Asiatic river clams 68

36. Concentration of boron in livers of waterfowl and water birds from the Salton Sea area, 1988-90, and threshold for reduced weight gain 69

37. Concentration of boron in black-necked stilt eggs from the Salton Sea area, 1988-90, and threshold for reduced weight gain $\mathbf{7 0}$

38. Concentration of boron in food-chain organisms of the Salton Sea, 1986-90, and dietary thresholds for waterfowl $\mathbf{7 1}$

39. Concentration of boron in food-chain organisms of rivers and drains in the Imperial Valley, 1988-90, and dietary threshold for waterfowl $\mathbf{7 2}$

40. Concentration of total-DDT in transplanted Asiatic river clams 76

41. Concentration of total-DDT for three species of fish from the Salton Sea, 1988-90, and dietary thresholds for fish-eating birds and mammals 78

42. Concentration of p,p'-DDE in black-necked stilt eggs from the Imperial Valley, 1988-90, and reproductive-impairment thresholds for selected bird species 81

43. Regression plot of $\log$ p,p'-DDE concentration and log eggshell thickness for black-necked stilts in the Imperial Valley, 1988-89 82

44. Concentration of p,p'-DDE in food-chain organisms of the Salton Sea, 1988-90, and dietary threshold for predators 84

45. Concentration of $p, p^{\prime}-D D E$ in food-chain organisms of rivers and drains in the Imperial Valley, 1988-90, and dietary threshold for predators 84

\section{TABLES}

1. Subsurface-drainwater sampling sites in the Imperial Valley

2. Biological sampling sites and constituents analyzed 23

3. Samples collected at biological sites, 1988-90 26

4. Summary of laboratories, analyses performed, and mediums analyzed for biological samples 28

5. Acceptable accuracy and precision guidelines, and reporting limits, for chemical analyses of biological samples 29

6. Summary statistics for selected constituents in monthly samples of water from 15 subsurface drains in the Imperial Valley, August 1988-August 198937

7. Summary statistics for selected constituents in monthly samples of water from six sites in the Imperial Valley, August 1988-August 198938

8. Selenium concentration in biota, Salton Sea area, 1988-90 58

9. Selenium concentration in biota from the Salton Sea area and other locations $\mathbf{5 9}$

10. Selenium concentration in aquatic-bird livers collected from the Imperial Valley, 1986-90 62

11. Boron concentration in biota from the Salton Sea area, 1986-90 66

12. Boron concentration in filamentous algae and submerged aquatic vegetation from the Salton Sea area and other locations, $1988-90$ 
13. Total-DDT concentration in biota from the Salton Sea area, 1986-90 74

14. $p, p^{\prime}-$ DDE concentration in biota from the Salton Sea area, 1986-90 75

15. $\mathrm{p}, \mathrm{p}$ '-DDE concentrations in mosquitofish from California drainwater areas and in fish sampled in the National Contaminant Biomonitoring Program 76

16. p,p'-DDE concentrations in cormorant tissues from the Salton Sea area and from contaminated sites in the Southern and Western United States 80

17. Active nests of colonial water birds at major rookeries along the Salton Sea shoreline, 1986-91 81

18. p,p'-DDE concentration in black-necked stilt eggs from neighborhoods in the Imperial Valley, 1988-89 83

19. Concentrations of selected organochlorine pesticides in biotic samples collected from the Salton Sea area and the Imperial Valley, 1986-90 85

20. Summary of agriculture-related contaminants of concern for birds subject to potential adverse effects in the Salton Sea area 88

21. Number of bird species by category (resident, migratory, federally endangered) in the Salton Sea area actually or potentially adversely affected by selenium, boron, or DDE 93

\section{CONVERSION FACTORS, VERTICAL DATUM, ABBREVIATIONS, AND DEFINITIONS OF TERMS}

\section{Conversion Factors}

\begin{tabular}{rcl} 
Multiply & By & To obtain \\
acre & 0.4047 & hectare \\
acre-foot (acre-ft) & 1,233 & cubic meter \\
acre-foot (acre-ft) & 0.001233 & cubic hectometer \\
cubic foot per second (ft $/$ s) & 0.02832 & cubic meter per second \\
foot (ft) & 0.3048 & meter \\
foot per year (ft/yr) & 0.3048 & meter per year \\
inch (in.) & 25.4 & millimeter \\
mile (mi) & 1.609 & kilometer \\
ounce, avoirdupois (oz) & 28.35 & gram \\
pound, avoirdupois (lb) & 0.4536 & kilogram \\
ton, short & 0.9072 & megagram \\
\hline
\end{tabular}

Temperature is given in degrees Celsius $\left({ }^{\circ} \mathrm{C}\right)$, which can be converted to degrees Fahrenheit $\left({ }^{\circ} \mathrm{F}\right)$ by the following equation:

$$
{ }^{\circ} \mathrm{F}=1.8\left({ }^{\circ} \mathrm{C}\right)+32 \text {. }
$$

\section{Vertical Datum}

Sea Level: In this report, "sea level" refers to the National Geodetic Vertical Datum of 1929--a geodetic datum derived from a general adjustment of the first-order level nets of the United States and Canada, formerly called Sea Level Datum of 1929. 


$\begin{array}{ll}\text { Abbreviations } & \\ \text { CTSMP } & \text { California Toxic Substances Monitoring Program } \\ \text { NCBP } & \text { National Contaminant Biomonitoring Program (U.S. Fish and Wildlife Service) } \\ \text { NIWQP } & \text { National Irrigation Water-Quality Program (U.S. Department of the Interior) } \\ \text { NWR } & \text { National Wildlife Refuge } \\ \text { WA } & \text { Wildlife Area } \\ \text { WMA } & \text { Wildlife Management Area } \\ \mathrm{PVC} & \text { polyvinyl chloride } \\ \mathrm{kg} / \mathrm{ha} & \text { kilogram per hectare } \\ \mathrm{mg} / \mathrm{kg} & \text { milligram per kilogram } \\ \mathrm{mg} / \mathrm{L} & \text { milligram per liter } \\ \mu \mathrm{g} / \mathrm{g} & \text { microgram per gram } \\ \mu \mathrm{g} / \mathrm{kg} & \text { microgram per kilogram } \\ \mu \mathrm{g} / \mathrm{L} & \text { microgram per liter } \\ \mu \mathrm{m} & \text { micrometer } \\ \mu \mathrm{S} & \text { microsiemen } \\ \mu \mathrm{S} / \mathrm{cm} & \text { microsiemen per centimeter at } 25^{\circ} \mathrm{C} \\ \mathrm{ppb} & \text { part per billion } \\ \mathrm{ppm} & \text { part per million } \\ \mathrm{ppt} & \text { part per thousand } \\ \mathrm{TU} & \text { tritium unit }\end{array}$

\section{Definitions of Terms}

Bioaccumulation-A process by which chemicals are taken up by an organism directly (from water, for example) or through consumption of food containing the chemicals (modified from Rand and Petrocelli, 1985, p. 652).

Biomagnification-An increase in tissue concentration of a bioaccumulated constituent as the constituent passes upward through two or more trophic levels in a food chain.

Biominification-A decrease in tissue concentration of a bioaccumulated constituent as the constituent passes upward through two or more trophic levels in a food chain.

Depuration-A cleansing or purification process. For example, the elimination of contaminant burdens in clams through flushing.

Detection limit-The minimum concentration of a substance that can be identified, measured, and reported with 99-percent confidence that the analyte concentration is greater than zero (Pritt and Jones, 1989).

Reference site-As used in this report, a site that is not significantly affected by agricultural drainwater.

Reporting limit (reporting level)-The lowest measured concentration of a constituent that can be reliably reported using a given analytical method. Because of unpredictable matrix effects on detection limits, the reporting limit is set somewhat higher than the detection limit (Pritt and Jones, 1989).

Shorebirds-A diverse group of mostly migratory wading or swimming birds of the suborder Charadrii that feed primarily on invertebrates along shorelines. Most have long pointed wings, long legs, and webbed toes. [Examples in this study area are black-necked stilt (Himantopus mexicanus) and long-billed dowitcher (Limnodromus scolopaceus).]

Water birds-A general term for swimming, diving, or wading birds with lobate toes. [Examples in this study area are American coot (Fulica americana), eared grebe (Podiceps nigricellis), and white-faced ibis (Plegadis chihi).]

Waterfowl-Specialized swimming or diving birds of the order Anseriformes. Characteristics include long necks, narrow and pointed wings, short legs, and webbed toes. They are well insulated with down feathers, and have flattened bills with serrated edges to strain their food. [Examples in this study area are northern shoveler (Anas clypeata) and ruddy duck (Oxyura jamaicensis).]

Water year-The water year starts October 1 and ends September 30; it is designated (water year 1989, for example) by the calendar year in which it ends. 


\title{
DETAILED STUDY OF WATER QUALITY, BOTTOM SEDIMENT, AND BIOTA ASSOCIATED WITH IRRIGATION DRAINAGE IN THE
}

\section{SALTON SEA AREA, CALIFORNIA, 1988-90}

\author{
By James $G$. Setmire, Roy A. Schroeder, and Jill N. Densmore, \\ U.S. Geological Survey, and
}

Steven L. Goodbred, Daniel J. Audet, and William R. Radke, U.S. Fish and Wildlife Service

\begin{abstract}
A detailed study of the Salton Sea area by the National Irrigation Water-Quality Program, U.S. Department of the Interior, was completed in 1990. Overall objectives of the study were to assess the extent, magnitude, and effects of contamination associated with agricultural drainage on migratory and resident birds and their habitats, and to determine the sources and exposure pathways of contaminants.
\end{abstract}

Results of the study indicate that factors controlling contaminant concentrations in subsurface drainwater in the Imperial Valley are soil characteristics, hydrology, and agricultural practices. Higher contaminant concentrations commonly were associated with clayey soils, which retard the movement of irrigation water and thus increase concentration by evaporation.

Regression of hydrogen- and oxygen-isotope ratios in samples collected from sumps yields a linear drainwater evaporation line that extrapolates through the isotopic composition of Colorado River water, thus demonstrating that Colorado River water is the sole source of subsurface drainwater in the Imperial Valley. Ratios of selenium to chloride indicate that selenium present in subsurface drainwater throughout the Imperial Valley originates from the Colorado River. The average annual selenium load discharged to the Salton Sea from the Alamo River, which is the largest contributor of selenium to the Salton Sea, is about 6.5 tons. The New River contributes 2.5 tons, 2.0 tons of which originates from within the Imperial Valley and the remainder from Mexico.

Biological sampling and analysis showed that drainwater contaminants, including selenium, boron, and DDE, are accumulating in tissues of migratory and resident birds that use food sources in the Imperial Valley and Salton Sea. Selenium concentrations in fish-eating birds, shorebirds, and the endangered Yuma clapper rail were at levels that could affect reproduction. Selenium bioaccumulated in "clean" Asiatic river clams placed in a major irrigation drain during spring planting. Indigenous clams accumulated selenium in proportion to inflow of irrigation drainwater, demonstrating that clams can serve as excellent biomonitors. Boron concentrations in migratory waterfowl and resident shorebirds were at levels that potentially could cause reduced growth in young. Waterfowl and fish-eating birds in the Imperial Valley may be experiencing reproductive impairment as a result of DDE contamination of food sources. Some of the highest concentrations of DDE were found in birds feeding in agricultural fields on invertebrates and other food items. A total of 19 organochlorine pesticides, in addition to DDE and its metabolites, were found in biota. Of these, only two, toxaphene and hexachlorobenzene, were detected at levels greater 
than 1 microgram per gram wet weight. No organochlorine pesticide residues greater than the National Academy of Sciences threshold of 1 microgram per gram to protect fish-eating birds were found in fish.

\section{INTRODUCTION}

\section{BACKGROUND}

State and Federal agencies, as well as private citizens, have expressed concern that contamination of the Salton Sea by agricultural drainwater is occurring and that it may pose a threat to human health and to the survival of fish and wildlife resources of the Salton Sea area. In 1986, the U.S. Department of the Interior began an investigation of irrigation drainage in the Salton Sea area. The initial phase of the investigation, a reconnaissance, was completed in 1988. Results of the reconnaissance, reported by Setmire and others (1990), indicated that selenium, boron, and DDT metabolites were present at elevated concentrations that could cause physiological harm to resident wildlife and fish of the Salton Sea National Wildlife Refuge (NWR). Selenium concentrations were as high as $42 \mu \mathrm{g} / \mathrm{g}$ dry weight in livers of fisheating birds, and boron concentrations were as high as $370 \mu \mathrm{g} / \mathrm{g}$ dry weight in aquatic vegetation.

During the reconnaissance study, elevated concentrations of selenium were detected in samples of water and bottom sediment collected in the Imperial Valley. The highest measured selenium concentrations were in irrigation drainage, which consists of a concentrate from the percolation of irrigation water through shallow (usually about $6 \mathrm{ft}$ ) soil. Bottom-sediment samples collected from the Salton Sea had the highest concentrations found in sediment. These reconnaissance results indicated the need for a more detailed study in the Imperial Valley.

\section{ACKNOWLEDGMENTS}

The detailed study was a joint effort conducted by scientists from the U.S. Geological Survey (USGS) and the U.S. Fish and Wildlife Service. Financial support also was provided by the U.S. Bureau of Reclamation and the U.S. Bureau of Indian Affairs under the Department of the Interior's National Irrigation Water-Quality Program (NIWQP). Additional financial support was provided by the California Regional Water Quality Control Board, Colorado River Basin Region, who also assisted in the collection of some drainwater samples. Imperial Irrigation District helped secure access to selected sites and also assisted in the collection of shallow soil samples.

\section{PURPOSE AND SCOPE}

This report presents the results of a detailed study of irrigation drainage and its effects in the Salton Sea area completed in 1990. The USGS was responsible for determining the hydrologic and geochemical factors affecting concentrations of irrigation-induced contaminants, particularly selenium, and the U.S. Fish and Wildlife Service was responsible for identifying pathways of contaminant accumulation in biota. Results of the detailed investigation will serve as the scientific basis for planning and conducting remediation efforts under direction of the U.S. Bureau of Reclamation.

This report contains analysis and interpretation of the data collected for the detailed study. Summary tables are provided, as needed, to support the text. Because of the volume of biological, water, and bottom-sediment data collected during this intensive study, the actual data tables have not been included. A separate data report (Schroeder and others, 1993) has been released to provide this information. The soils data for the 15 fields sampled in the Imperial Valley and analyzed by the USGS Geologic Division laboratory in Denver, Colorado, are also presented in the data report.

The general goals of the Department of the Interior study were to: (1) determine the geographical extent and severity of existing and potential irrigationinduced water-quality problems, and (2) provide the scientific understanding needed for development of reasonable alternatives to mitigate or resolve identified problems. Within this context, the overall objectives of the detailed study were to determine the extent, magnitude, and effects of contaminants associated with agricultural drainage on migratory birds and their habitats and, where effects are documented, to determine the sources and exposure pathways of contaminants.

Specific objectives were developed for the detailed study on the basis of results of the reconnaissance investigation, using the general goals as a framework. Included in this development process were the selecting and prioritizing of biotic collections from the Salton Sea NWR and adjacent areas. High priorities were assigned to organisms most likely, 


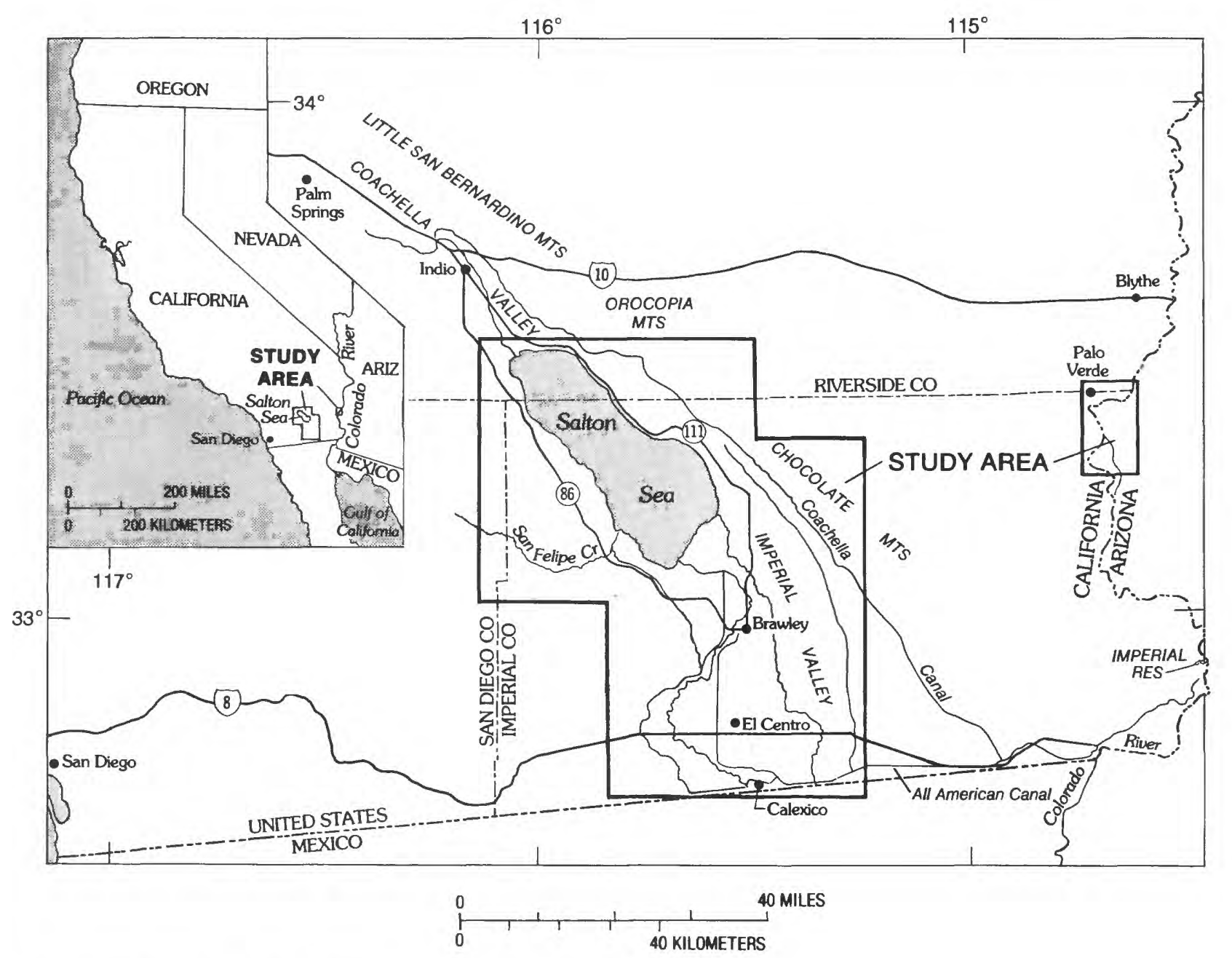

Figure 1. Location of study area.

because of their ecological niche, to show effects of contaminant exposure. The potential exposure of endangered species to contaminants also was considered. to:

The specific objectives of the detailed study were

1. Determine the source and movement of selenium and boron in the agricultural system of the Imperial Valley and the processes affecting movement and concentrations of these elements.

2. Determine if selenium and (or) other contaminants associated with agricultural drainwater are accumulating in selected migratory bird species using the Salton Sea NWR as a wintering area.

3. Determine if drainwater contaminants have caused any adverse chronic or sublethal effects on resident birds that nest in the Salton Sea area or if there is the potential for adverse effects on reproductive success of migratory birds using the Salton Sea as a wintering area.

4. Evaluate the bioaccumulation of selenium and (or) other drainwater contaminants in aquatic food-chain organisms important to fish and to migratory and resident birds.

5. Determine if selenium and (or) other contaminants could be bioaccumulated by transplanted freshwater clams exposed to drainwater discharges. If so, determine seasonal variation in bioaccumulation of contaminants in the transplanted clams.

\section{DESCRIPTION OF STUDY AREA}

The study area for the reconnaissance investigation consisted of the major agricultural areas of the Coachella and Imperial Valleys (fig. 1). Because several 


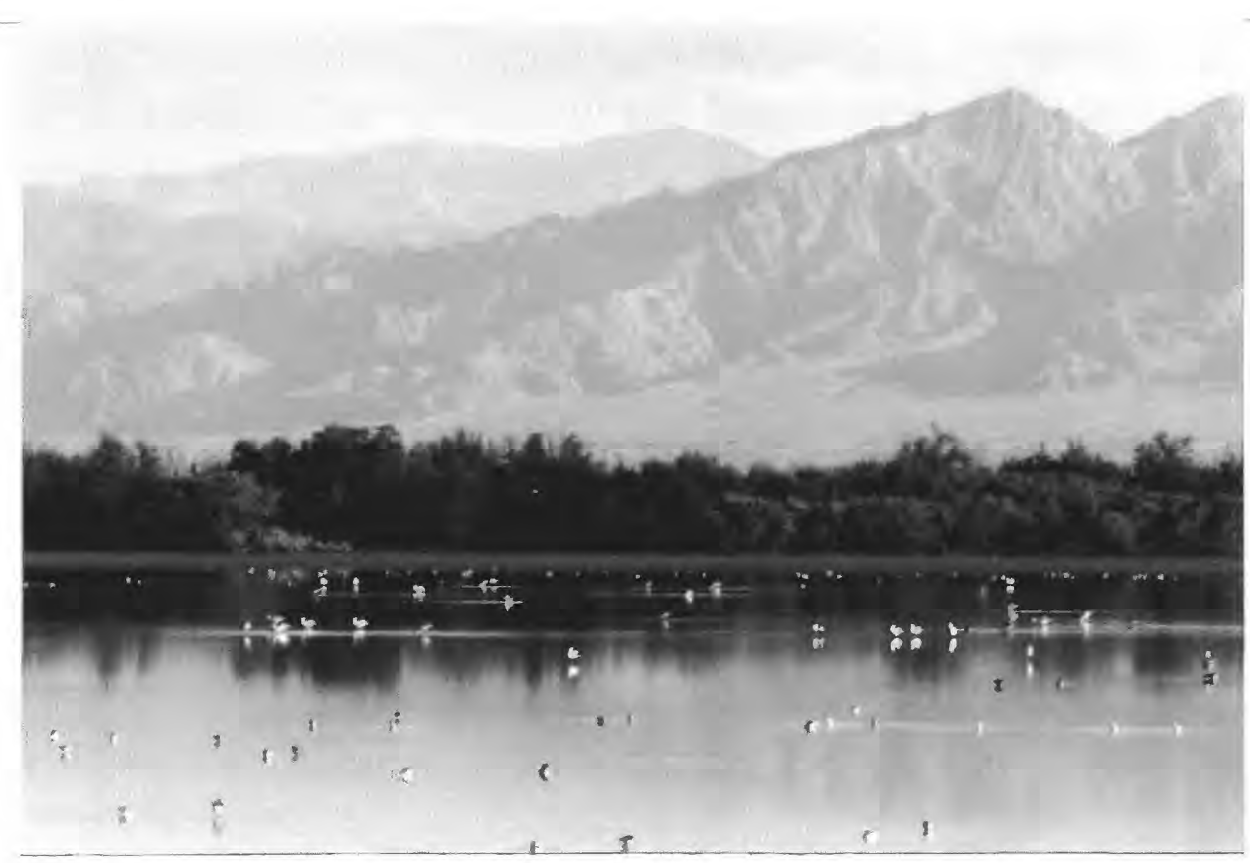

Figure 2. Water birds feeding on pileworms and waterboatmen at the south end of the Salton Sea. Looking east toward the Chocolate Mountains.

wildlife refuges are in the Imperial Valley, this detailed study focused primarily on the southern end of the Salton Sea and on irrigation drainage originating in the Imperial Valley. A detailed discussion of the geology and history of the Salton Sea area was presented in the reconnaissance-investigation report (Setmire and others, 1990). Comprehensive information on the biology and ecology of the Salton Sea is presented in the following section of this report.

\section{ECOLOGY OF SALTON SEA AREA}

The Salton Sea (figs. 2 and 3), California's largest inland body of water, is in essence manmade and has a largely manmade ecosystem (Hagar and Garcia, 1988). The relatively recent formation of the Salton $\mathrm{Sea}$, and the subsequent introduction of numerous species that were not native to this area, have resulted in a rather simplified regional ecosystem. Because Salton Sea food chains are short and the food webs lack diversity, any changes in lower trophic levels may dramatically alter the populations of top predators such as fish-eating birds. The general ecology of the Salton Sea has changed little since Walker (1961) conducted extensive investigations relating to the fishery, and the discussion that follows is based primarily on his extensive work.

The Salton Sea lies within the Cahuilla Basin, or Salton Sink, an actively spreading rift valley that is below sea level. Fossil evidence indicates at least short durations of seawater inundation, implying that the basin was a continuation of the Gulf of California prior to the formation of the Colorado River delta. Formation of the delta separated the valley from the Gulf and created a closed basin containing the Imperial Valley. In geologically recent times, the Colorado River's flow periodically has emptied into the Imperial Valley for varying lengths of time. The volume of shells left by freshwater mollusks and deposits of calcium carbonate show that Lake Cahuilla, the most recent of the inland seas (about 1,500 years before the present), was not saline (Walker, 1961).

Uncontrolled flooding during 1905 diverted the Colorado River from its course to the Gulf of California into the Cahuilla Basin and created the Salton Sea. Since 1907, water that is influenced by irrigation practices in the agriculturally rich Coachella and Imperial Valleys has entered the Salton Sea through a system of controlled drains. By Executive orders in 1924 and 1928, ownership of Federal land under the Salton Sea was withdrawn for the purpose of establishing a repository for agricultural drainwater. Although an estimated 1,328,800 acre-ft of water drains into the Salton Sea each year, annual evaporation of about $6 \mathrm{ft}$ maintains the surface at a fairly stable elevation, highest in the spring and lowest in autumn (Setmire and others, 1990). Currently, 


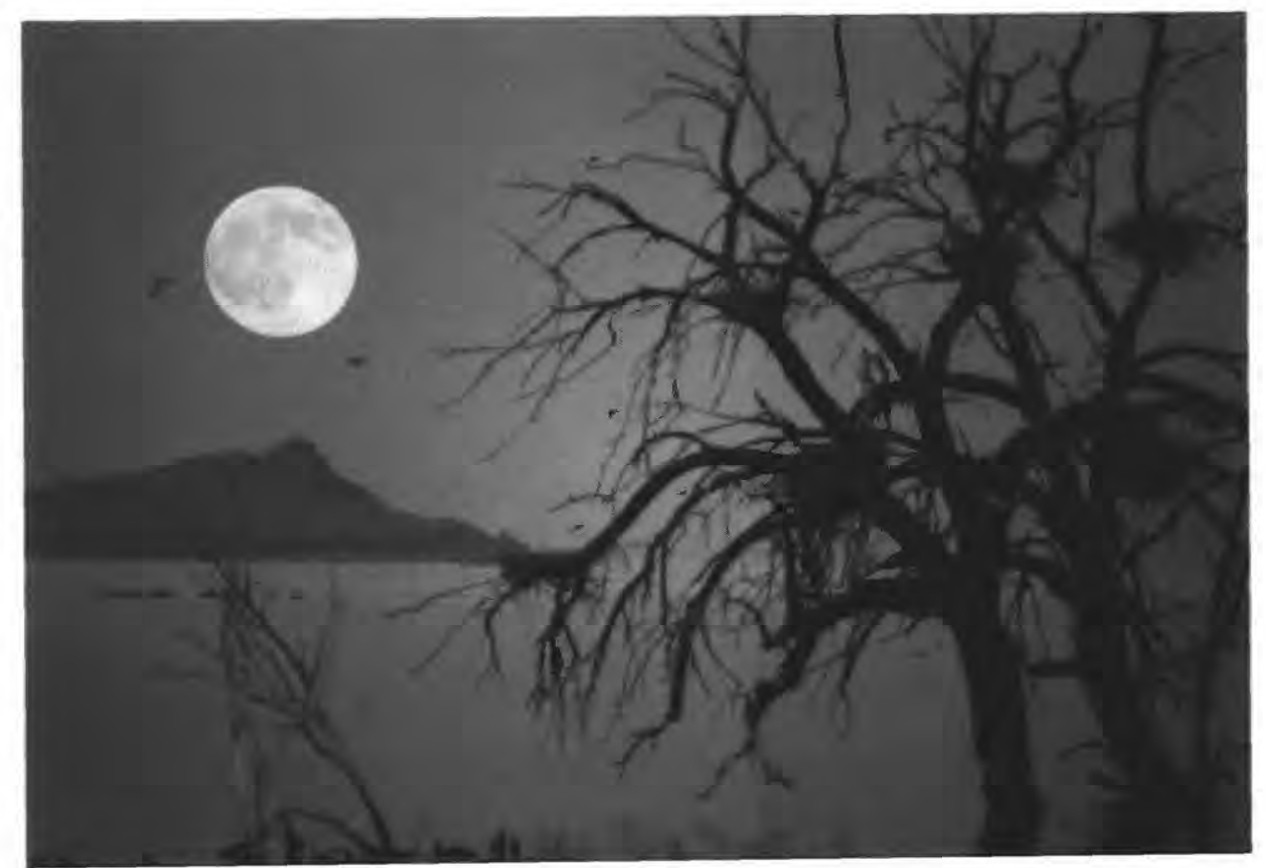

Figure 3. Abandoned colonial bird nests at the south end of the Salton Sea.

the surface elevation of the Salton Sea is about $226 \mathrm{ft}$ below sea level and its greatest depth is about $50 \mathrm{ft}$.

The salinity of the Salton Sea is as high as $44 \mathrm{ppt}$ (parts per thousand), which is about 25 percent greater than that of the Pacific Ocean (Hagar and Garcia, 1988). Because the Salton Sea lies within a closed basin having little rainfall and a high rate of evaporation, salinity historically has increased (U.S. Department of the Interior and the Resources Agency of California, 1974). The Salton Sea is less saline at the mouths of major drains and rivers; this condition is reflected by greater species diversity in these areas.

Another major ecological influence is solar radiation, which causes differences between surface and bottom temperatures (thermal stratification) and, in turn, affects the dissolved-oxygen content of water. Dissolved-oxygen content also can be affected by eutrophication and by wind-induced resuspension of anaerobic sediments. As salinity increases, oxygen becomes increasingly less soluble, and organisms become more susceptible to temperature stress (Hagar and Garcia, 1988). In addition, temperature and salinity can interact with factors such as parasitism (Moles and Pella, 1984) and concentrations of toxic substances (Bryant and others, 1984) to influence plant and animal life in the Salton Sea.

Studies of dissolved oxygen in the Salton Sea have indicated great diurnal changes in the oxygen content of nearshore water. Dissolved oxygen is present in high concentrations throughout the water column during winter, but commonly is absent (anaerobic conditions) at the bottom of the column on windless summer days. These changes affect the seasonal abundance of benthic organisms and of species dependent on those organisms as a source of food. During the eventual mixing that follows oxygen depletion at the bottom of the Salton Sea, dissolved-oxygen concentration at the water surface can be lowered temporarily below the minimum level necessary to maintain many forms of life. In addition, high concentrations of sulfide and ammonia present at the bottom during the summer are mixed into surface water and result in annual fish kills, which provide a supplement to the diet of thousands of gulls, herons, cormorants, pelicans, and other wildlife such as raccoons (Procyon lotor).

There are several relatively simple food chains in the study area. In the Salton Sea itself, the only organisms capable of producing food from sunlight and nutrients are phytoplankton and macroscopic algae. These foods are eaten by animals that use them for growth, maintenance, and to provide energy. Food that is oxidized for energy is broken down into simpler molecular components that become available for use by plants through a process called cycling. There is an energy loss at each step of the food chain because each animal in the chain passes on to its successor only a part of the energy from the food that 


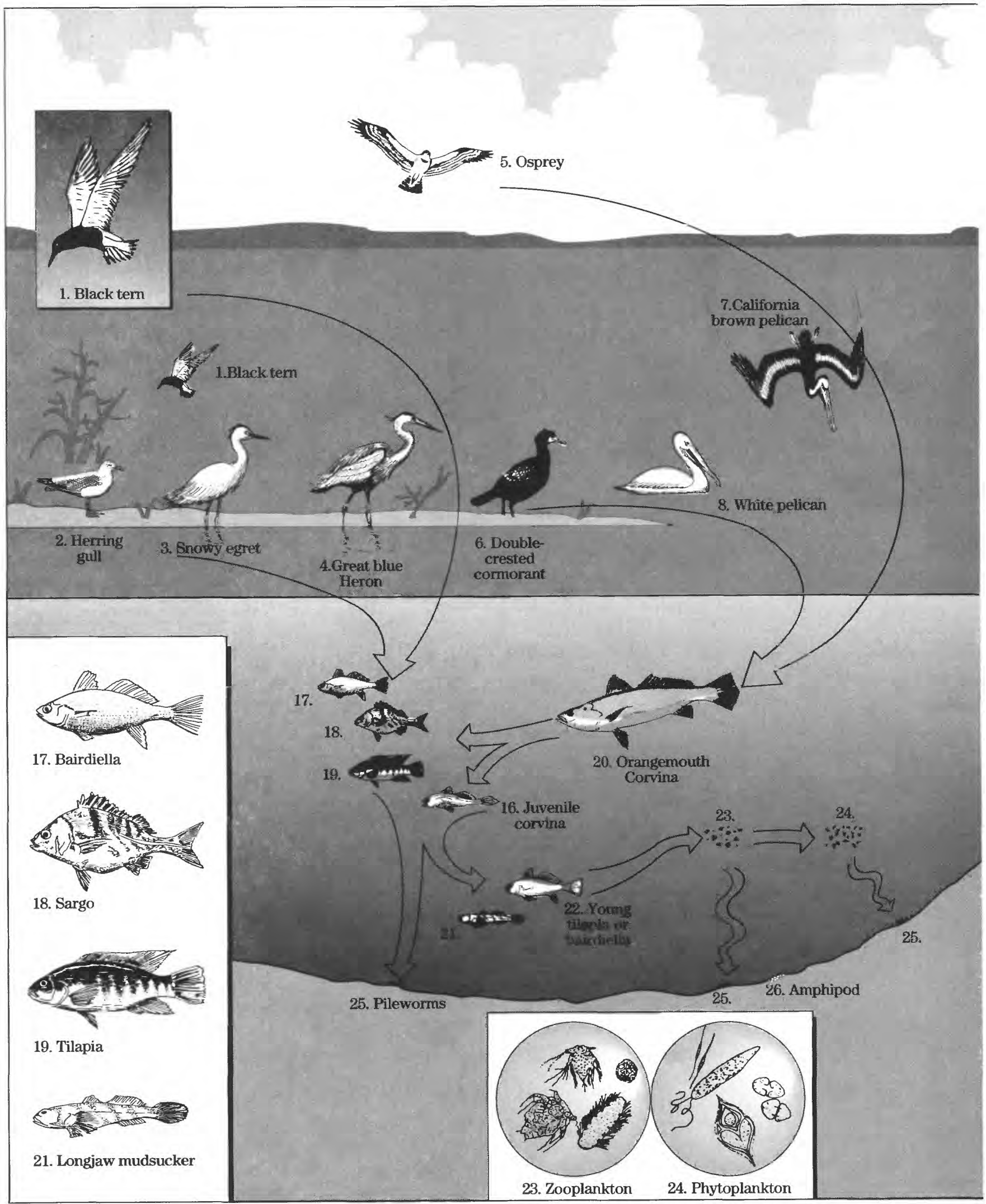

Figure 4. Trophic and bioaccumulation relations among organisms of the Salton Sea. 


\section{EXPLANATION}

[Selenium (Se) and boron (B) concentrations in micrograms per gram (dry weight), except concentrations in water in milligrams per liter; DDE concentrations in micrograms per gram (wet weight). -, no data. <, less than indicated reporting limit.

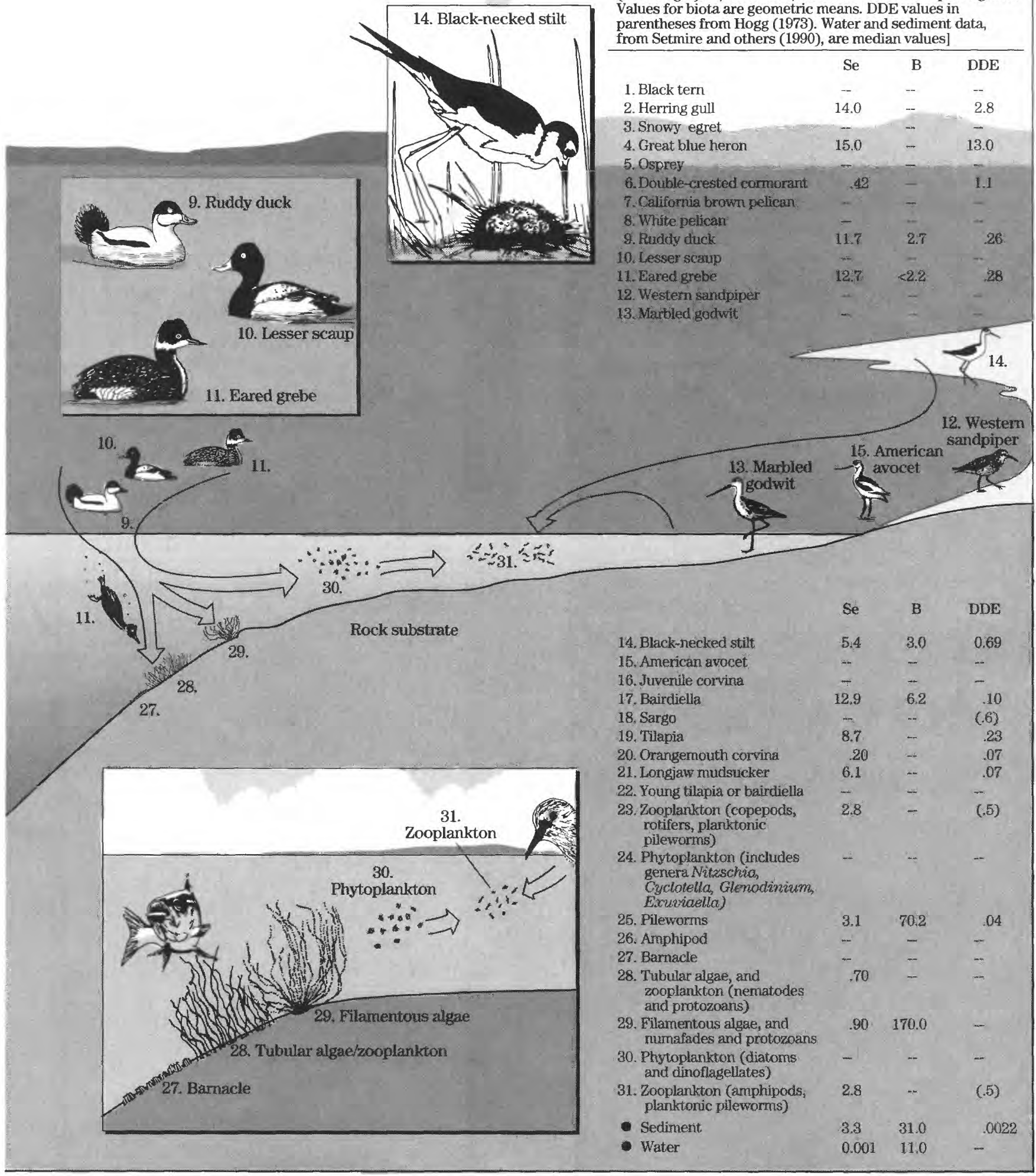

Figure 4. Continued. 


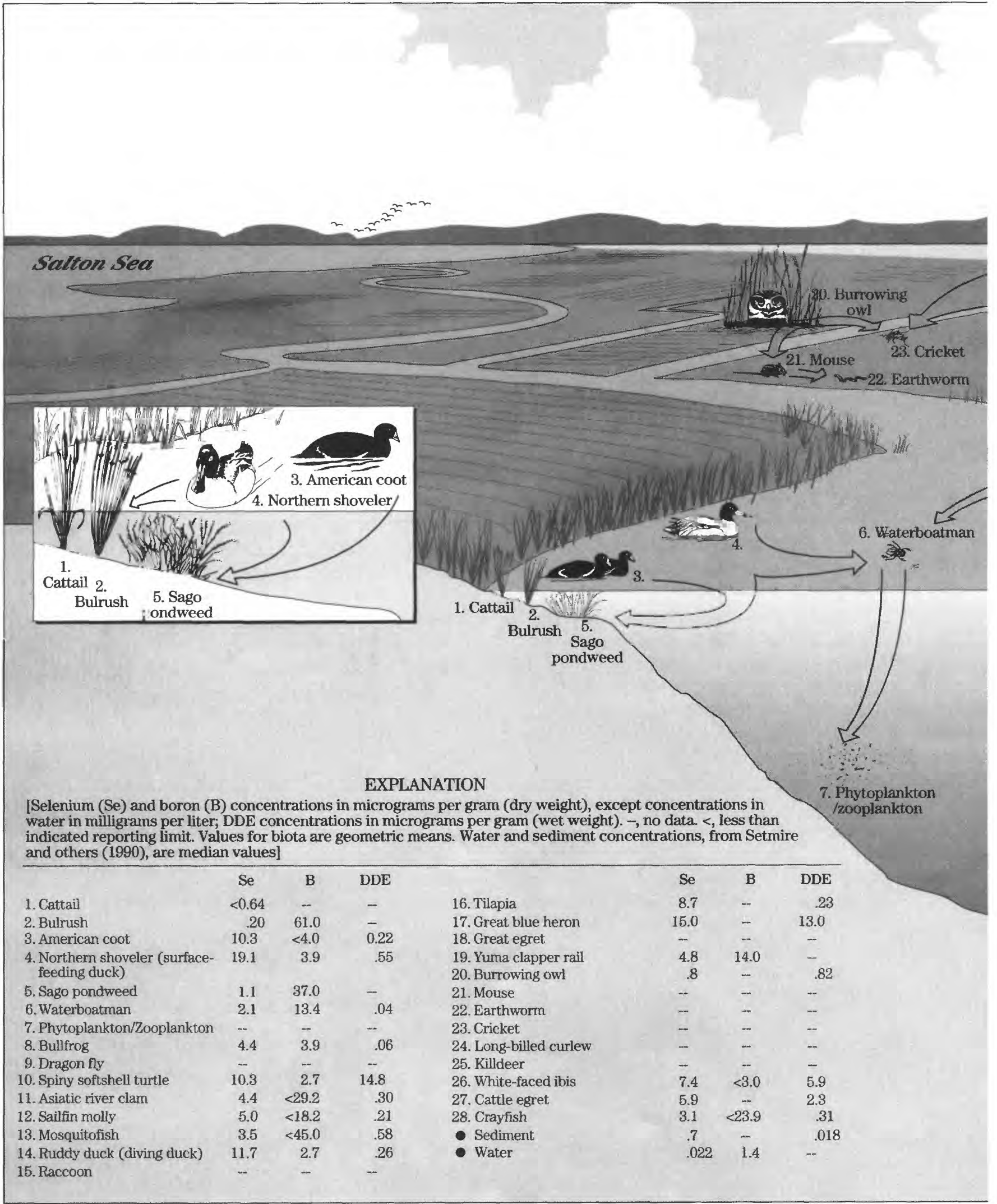

Figure 5. Trophic and bioaccumulation relations among organisms of rivers and drains in the Imperial Valley. 


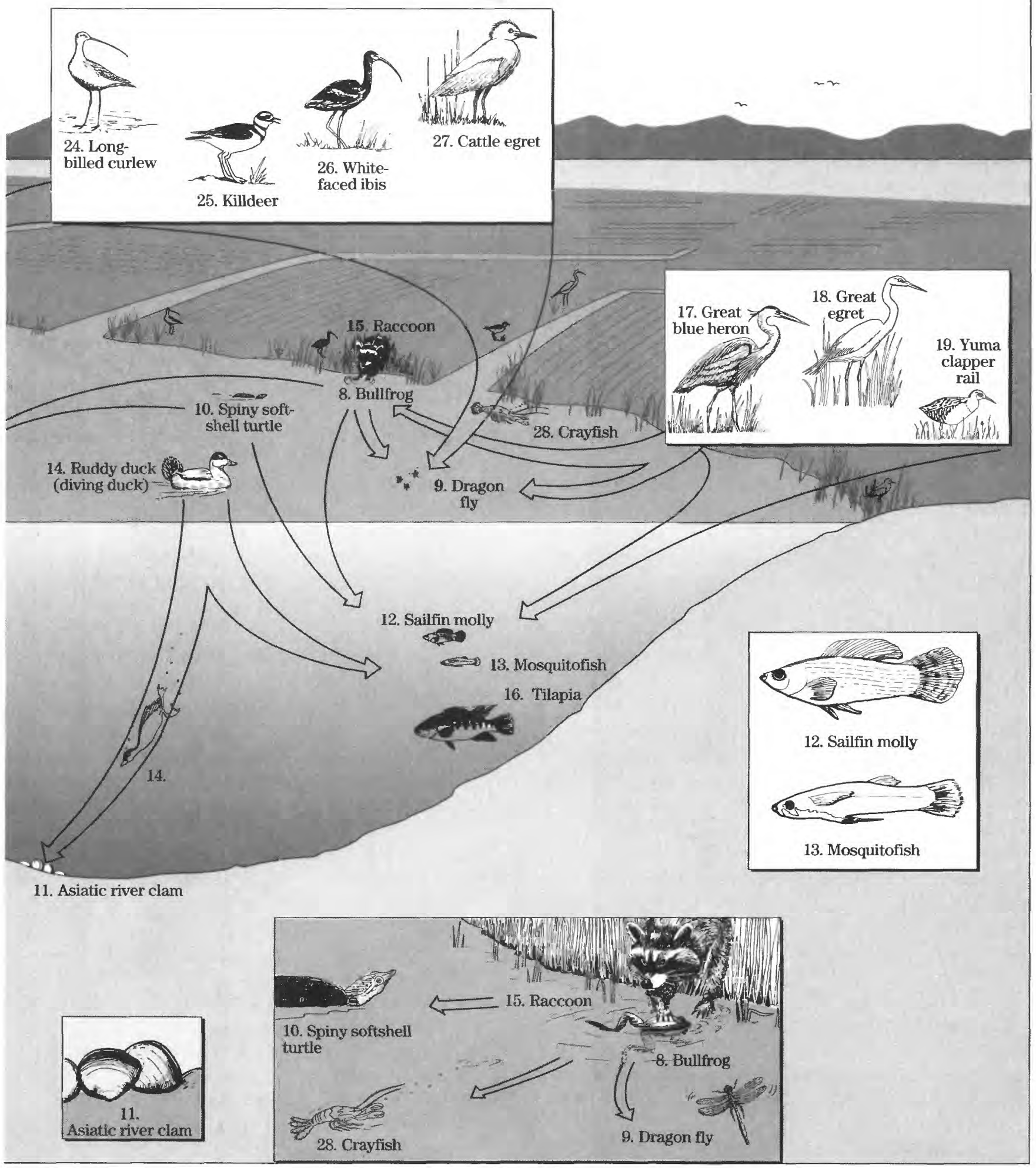

Figure 5. Continued. 
it has consumed (Ricklefs, 1973). Any level of the food chain can contribute to the production of detritus, which is nonliving animal and plant matter. Perhaps the most prominent food chains in the Salton Sea are (1) phytoplankton $\rightarrow$ zooplankton $\rightarrow$ pileworm $\rightarrow$ forage fish $\rightarrow$ predatory fish $\rightarrow$ fisheating bird, and (2) a shorter chain: phytoplankton $\rightarrow$ zooplankton pileworm $\rightarrow$ water bird. Many species of migratory waterfowl forage primarily on emergent and submergent vegetation; this represents one of the shortest food chains in the Salton Sea ecosystem. Ultimately, some of the waterfowl and gamefish progress farther through the food chain through consumption by humans. The basic ecology of the Salton Sea and relations among organisms of different trophic levels are shown in figures 4 and 5.

Primary productivity in the Salton Sea is accomplished by phytoplankton, which photosynthesize radiant energy to produce carbohydrates, proteins, and fats from naturally occurring carbon dioxide, bicarbonate, nitrate, ammonia, and phosphate dissolved in the water. The Salton Sea produces more phytoplankton on a per-unit-volume basis than does fertile coastal ocean water. Because of turbidity and the volume of planktonic life in the Salton Sea, however, it is estimated that only the top $3 \mathrm{ft}$ of the water column receives enough light to support photosynthesis (the photic zone). In the Salton Sea, phytoplankton are represented primarily by several pennate diatom species and dinoflagellates.

Diatoms are found throughout the Salton Sea; whereas, dinoflagellates normally are found close to shore and are subject to local blooms. Because of their large size and numbers, species from two genera of diatoms, Nitzschia and Cyclotella, and two species of dinoflagellates, Glenodinium and Exuviaella, are most important in the Salton Sea. The dinoflagellates are present year round, but populations are relatively small during summer. Species of macroscopic green algae exist both in the freshwater drainages emptying into the Salton Sea and in the Salton Sea (for example, Enteromorpha sp.) itself. Blue-green algae grow on the bottom of the sea in shallow water or on pilings and buoys. Because benthic plants are limited to a narrow fringe around the periphery of the Salton Sea, they produce less biomass than do phytoplankton (Sumich, 1979).

Invertebrates in the Salton Sea are represented by protozoans, rotifers, bryozoans, nematodes, annelids, and arthropods. The most important of these in the food chains are the annelids and arthropods. Various species of mollusks are present only in freshwater tributaries. Protozoans and nematodes occur primarily in the algal mats and in decaying organic matter and are utilized to some extent by benthic organisms. The more planktonic rotifers provide food to filter-feeding animals in the Salton Sea, but the moss-like sessile bryozoans have not been widely observed in the food web.

Amphipods and pileworms (Nereis succinea) represent perhaps the most critical link in the food chains of the Salton Sea because they are the primary animals that convert detritus into food for other organisms. Amphipods are present in both freshwater and saline ecosystems-primarily as epibenthic organisms living in bottom debris, in macroscopic algae, and among sessile animals (Villee and others, 1973). Many amphipods burrow into sand or mud, and some are tube dwellers. The amphipods present in the Salton Sea are omnivores and scavengers, and they are eaten by numerous species of fish and birds.

Pileworms have been abundant since their introduction to the Salton Sea during the 1930's and are the principal detritus-feeding animals in the Salton Sea. Pileworms are restricted to substrates of fine sand and silt and spend most of their lives in burrows in mud or among masses of barnacles (Kuhl and Oglesby, 1979). Pileworms are most abundant in sediment at water depths of 15 to $25 \mathrm{ft}$, but they can be found seasonally at all depths in the Salton Sea. During summer, pileworms are not able to survive at depths greater than $30 \mathrm{ft}$ because of anaerobic conditions. Mature pileworms leave their burrows at night and swim to the surface to spawn. Spawning occurs throughout the year and peaks during spring and autumn (Kuhl and Oglesby, 1979). The eggs and larvae of pileworms are planktonic, and all stages of the pileworm are extremely important to Salton Sea food chains. Fish in the Salton Sea are largely dependent on pileworms, which have high protein and fat contents (Zenkevich, 1951).

The barnacle Balanus amphitrite was first observed at the Salton Sea in 1944 (Walker, 1961). Their distribution is limited by the availability of solid surface areas for attachment. Adult barnacles are eaten by fish only occasionally; however, the planktonic larvae are fed on by filter-feeding organisms and, to a limited extent, by young fish. Planktonic populations peak during spring and autumn and are low during winter. Barnacles are fed on by some wintering waterfowl, and many barnacle shells are washed up and deposited on Salton Sea beaches and crushed by wave action into a coarse sand. These "barnacle bars" impede some freshwater 
drainflow into the Salton Sea and also create ponds of water having various salinities. These ponds are used extensively as feeding and nesting areas by various shorebirds and by other wildlife.

Because the reproductive peaks of both pileworms and barnacles occur in spring and autumn, plankton are abundant during those seasons. However, zooplankton are present in the greatest total numbers in summer when rotifers and copepods appear. The most abundant planktonic species during summer is the rotifer Brachionus plicatilis. The copepod Cyclops dimorphus, which is present only during the warmest part of the year, is an important link in food chains of the Salton Sea because these copepods feed on phytoplankton and then are eaten by young fish. Dead rotifers and copepods add to the detritus on the bottom of the Salton Sea where they are fed on by bacteria and pileworms. Some bacteria use selenate in respiration, effectively transferring a significant amount of selenium from the water column into bottom sediment.

The Whitewater, Alamo, and New Rivers, and numerous smaller tributaries to the Salton Sea, convey water from agricultural lands in both the Imperial and Coachella Valleys. Although San Felipe Creek and Salt Creek do not serve as agricultural drains by design, both of these "natural" tributaries are influenced to some degree by either agriculture or aquaculture. All agricultural drains contain ecosystems composed largely of introduced organisms, including common reed (Phragmites communis), saltcedar (Tamarix sp.), Asiatic river clams (Corbicula fluminea), crayfish (Procambarus clarki), and numerous introduced fish species. A typical drainwater ecosystem might be: phytoplankton $\rightarrow$ zooplankton $\rightarrow$ aquatic insects $\rightarrow$ forage fish $\rightarrow$ water birds and turtles. Freshwater drains and ponds contain ample aquatic invertebrates, notably waterboatman (Corixidae), that also are found in the saltwaterfreshwater interface where drains enter the Salton Sea. Adult waterboatmen can fly, and they rapidly colonize new bodies of water, where they swim and feed on algae and minute submerged food particles (Milne and Milne, 1980). Waterboatmen are preyed on by numerous species of fish and by birds such as the black-necked stilt (Himantopus mexicanus). When agricultural fields are irrigated, earthworms and terrestrial insects such as crickets (Gryllus sp.) are flooded out, making them readily available to large numbers of cattle egrets (Bubulcus ibis), white-faced ibis (Plegadis chihi), long-billed curlews (Numenius americanus), and other birds that forage among the crops throughout the year.
Two introduced predators that are important to the region's food chains are the bullfrog (Rana catesbeiana) and the spiny softshell turtle (Trionyx spiniferus). Both species are common in the Salton Sea's freshwater inlets. Bullfrogs feed mostly on aquatic invertebrates in the drains, and they in turn are food for fish, herons, egrets, bitterns, skunks (Mephitis mephitis), raccoons, and humans. The spiny softshell turtle is abundant in freshwater drains, where it feeds on various invertebrates, frogs, and fish, or scavenges on dead organisms (Stebbins, 1985). Young softshell turtles become prey to various birds and mammals, but adult turtles are taken by few predators other than humans.

Although the endangered desert pupfish (Cyprinodon macularis) is the only fish native to the Salton Sea area, there currently are at least 15 introduced fish species that inhabit the Salton Sea and its associated drains. The chief gamefish of the Salton Sea is the orangemouth corvina (Cynoscion xanthulus), which supports a substantial sport fishery. Corvina occupy the top of the aquatic food chain and feed on tilapia (Tilapia mossambica), longjaw mudsuckers (Gillichthys mirabilis), bairdiella (Bairdiella icistia), and sargo (Anisotremus davidsoni). These important forage fish, in turn, feed on fish eggs, copepods, barnacle larvae, and amphipods, as well as pileworms, which constitute food for all but very young fish. An important limiting factor for some fish in the Salton Sea may be related to reduced abundance of pileworms during summer and early autumn. The Salton Sea currently is too saline to allow successful spawning by many of the inhabitant fish species (Lasker and others, 1972); however, some recruitment probably results from fish entering the Salton Sea from freshwater inlets and the less saline drain outlets at their confluence with the Salton Sea. Freshwater drains contain large numbers of tilapia (Tilapia zilli), carp (Cyprinus carpa), mosquitofish (Gambusia affinis), sailfin molly (Poecilia latipinna), longjaw mudsucker, and redfin shiner (Notropis umbratilis) - an important source of food for larger fish, predatory birds, and other animals.

Although corvina, sargo, and bairdiella eggs and larvae can tolerate current salinity levels in the Salton Sea (California Department of Fish and Game, 1987), production of these species likely is declining. In addition, tilapia in the Salton Sea experience significant population fluctuations resulting from low winter temperatures (Hagar and Garcia, 1988) and seem slow to reestablish themselves. Fish numbers continue to be stabilized by annual mortalities that occur during summer or early autumn as a result of food depletion, lack of oxygen, or a combination of factors. 


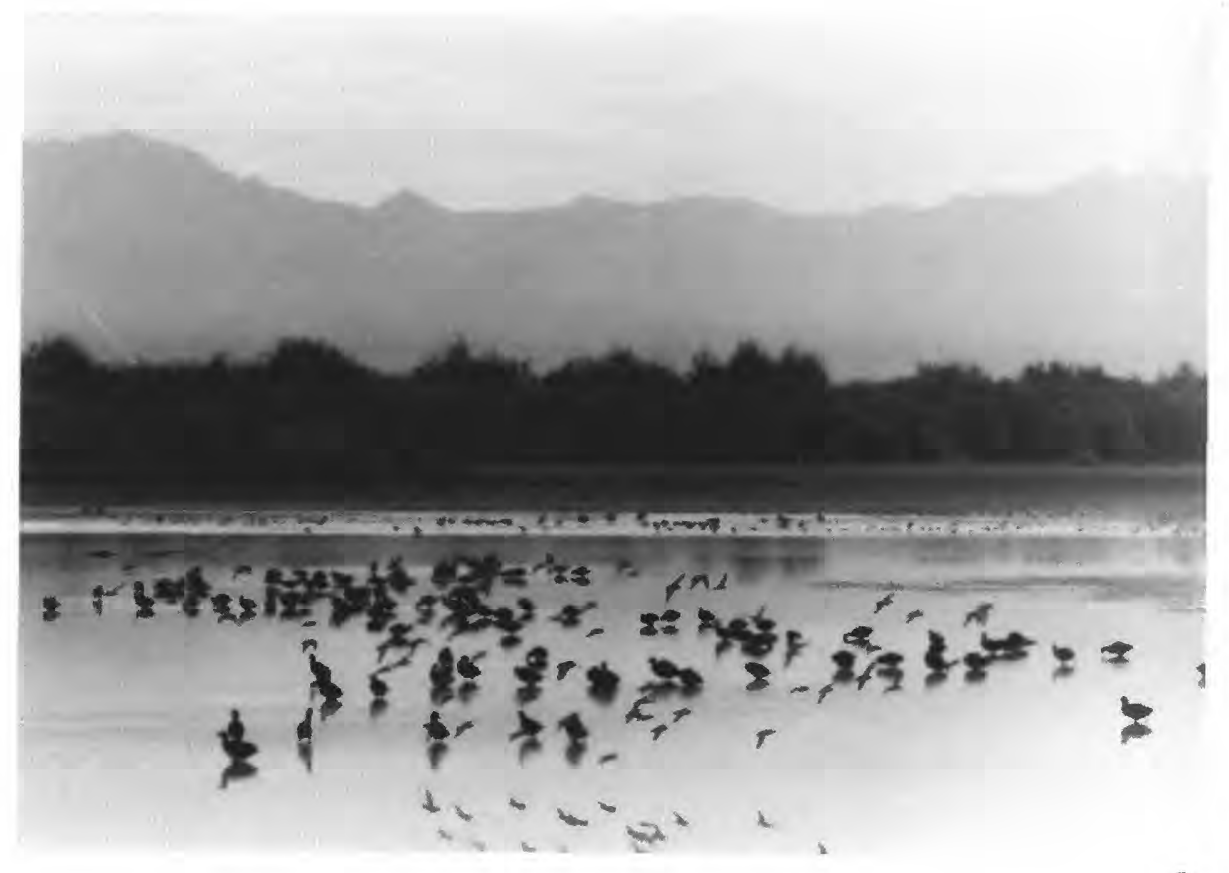

Figure 6. Numerous species of water birds in shallow-water habitat of the Salton Sea.

The Salton Sea supports an unusual diversity and abundance of birds: At least 375 species, including 93 nesting species, use the various habitats on or adjacent to the Salton Sea (figs. 6 and 7). Four of the birds that regularly utilize the area are listed by the U.S. Fish and Wildlife Service as endangered species: brown pelican (Pelecanus occidentalis), peregrine falcon (Falco peregrinus), bald eagle (Haliaeetus leucocephalus), and Yuma clapper rail (Rallus longirostris yumanensis). The Salton Sea's abundant supply of invertebrates directly supports large numbers of wintering waterfowl, grebes, and shorebirds. Numbers of waterfowl wintering at the Salton Sea have reached over 125,000 in recent years, and the number of eared grebes (Podiceps nigricollis) has been as high as 2 million. As many as 5,000 brown pelicans occasionally spend summer on the Salton Sea, and about one-third of the world's population of Yuma clapper rails depend on wetlands and associated invertebrates related to freshwater drains in the Salton Sea area.

Fish produced in the Salton Sea and its freshwater inlets provide abundant food for predatory species such as pelicans, cormorants, herons, egrets, terns, and osprey. Although bird numbers have significantly declined since 1988, as many as 2,000 (combined total) herons, cormorants, and egrets have been observed (in a survey) nesting at the southeast end of the Salton Sea alone. The Salton Sea provides the only inland nesting site in the United States for gullbilled terns (Gelochelidon nilotica) and provides three of only five nesting sites in the Western United States for black skimmers (Rynchops nigra). More than 30 species of shorebirds, with peak numbers of well over 100,000 individuals, use Salton Sea habitats during winter and migration periods (Page and others, 1990). Other shorebird species, such as the black-necked stilt, are abundant breeders.

At least 41 species of mammals are represented in the Salton Sea's ecosystem, including various herbivores, insectivores, and carnivores. Several species of rodents exist in terrestrial habitats, where they provide important food for raptors and other predators. During winter months, rodents are an important food source for herons and egrets. Coyotes (Canis latrans), raccoons, and striped skunks act both as predators and scavengers (Ingles, 1965), transferring energy farther through the food chain. Finally, humans exert extraordinary influence on all the existing habitats and represent the final trophic level in some Salton Sea food chains.

The creation of any new habitat invites a host of invading species that are quick to exploit available resources (Ricklefs, 1973). Not all species in a community are equally abundant, and organisms with high reproductive potentials tend to make the most complete use of the available food by varying their 


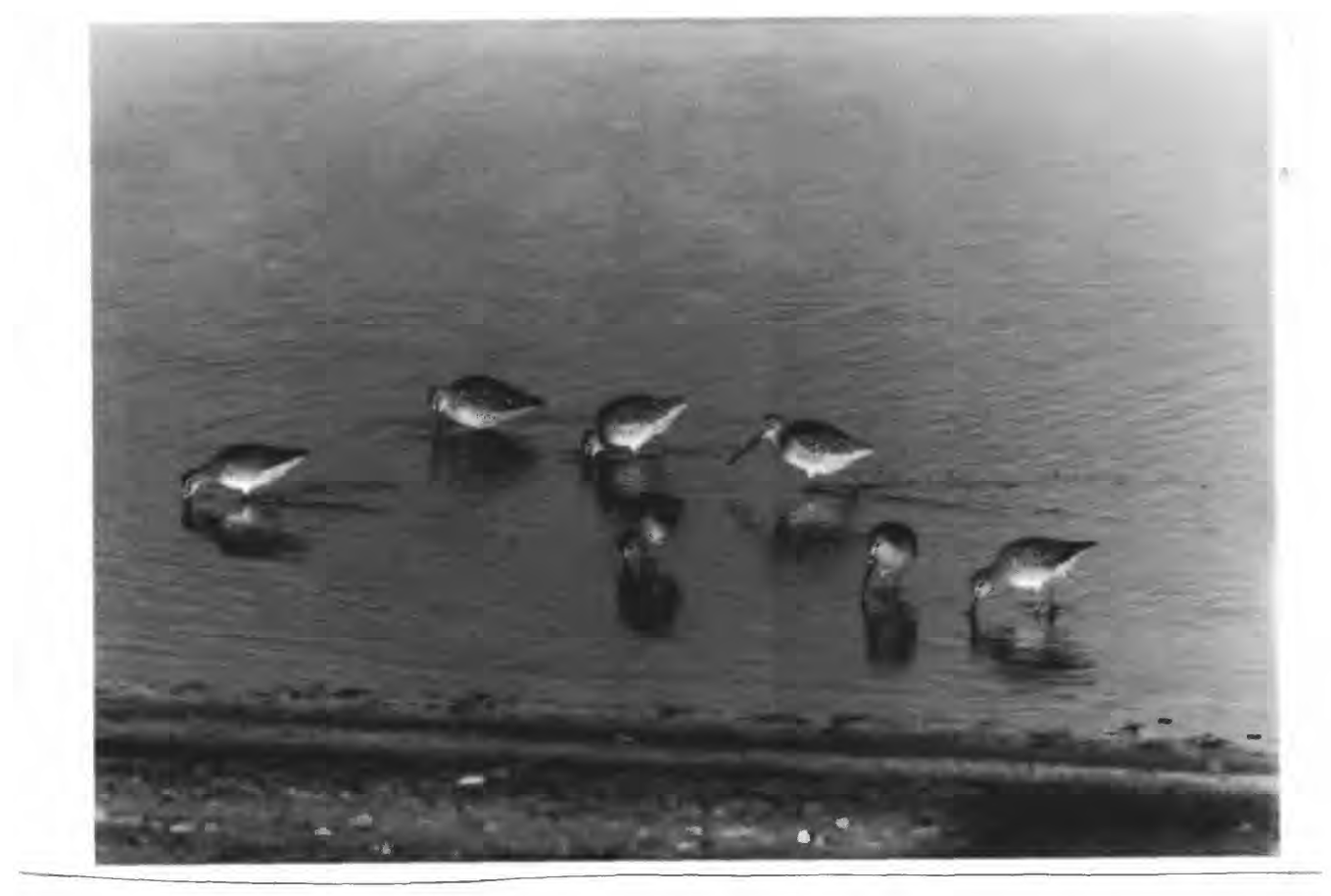

Figure 7. Dowitchers feeding on invertebrates at the south end of the Salton Sea.

populations to match the food supply. Pileworms exemplify this potential in the Salton Sea. Organisms with lower reproductive potential cannot adjust their population size as rapidly to food fluctuations and tend to stabilize near the low point of their food supply. Recent declines in nesting fish-eating birds at the Salton Sea might be a result of such low-point stabilization. Existing food chains are affected by the interactions between salinity and temperature as well as the influences of these interactions on dissolved oxygen (Hagar and Garcia, 1988). The tributaries that carry drainwater from agricultural fields in both the Imperial and Coachella Valleys into the Salton Sea have the potential to contribute contaminants into the ecosystem at most trophic levels.

\section{PREVIOUS INVESTIGATIONS}

Setmire and others (1990) collected water, bottom sediment, and biota samples during 1986-87 in the Salton Sea area to determine concentrations of trace elements and pesticide residues as part of the Department of Interior Irrigation Drainage Program. Results of this reconnaissance-level investigation indicated that selenium, boron, and DDT metabolites are major contaminants.

Elevated concentrations of selenium in water were found in tile-drain effluent. The highest selenium concentration of $300 \mu \mathrm{g} / \mathrm{L}$ was detected in a tile-drain sample, and the lowest concentration of $1 \mu \mathrm{g} / \mathrm{L}$ was detected in a composite sample of Salton Sea water. The median selenium concentration in 12 samples was $19 \mu \mathrm{g} / \mathrm{L}$. In contrast to the spatial pattern for water, the highest bottom-sediment concentration of 3.3 $\mathrm{mg} / \mathrm{kg}$ was in a composite sample from the Salton Sea.

In fish from the Salton Sea, selenium concentrations ranged from 3.5 to $20 \mu \mathrm{g} / \mathrm{g}$, dry weight, for tilapia and corvina; the mean concentration, $10.5 \mu \mathrm{g} / \mathrm{g}$ dry weight, exceeds the health advisory level of 8 $\mu \mathrm{g} / \mathrm{g}$ dry weight for human consumption of fish (Naven, 1983). Selenium was detected at concentrations as high as 27 and $42 \mu \mathrm{g} / \mathrm{g}$ dry weight in livers of black-necked stilt and double-crested cormorant (Phalacrocorax auritus). Although the biological effects of selenium at these concentrations were not observed, similar levels have been linked to reproductive problems at drainwater sites in other study areas.

Boron concentrations also were elevated in tiledrain effluent and in the Salton Sea. The median concentration in 12 water samples was $1,750 \mu \mathrm{g} / \mathrm{L}$ (Setmire and others, 1990). The highest concentration of $11,000 \mu \mathrm{g} / \mathrm{L}$ was in a composite sample from the Salton Sea. Trifolium Drain 1, which discharges directly to the Salton Sea, had a boron concentration 
of $1,300 \mu \mathrm{g} / \mathrm{L}$, and the Alamo River at the outlet to the Salton Sea had a concentration of $680 \mu \mathrm{g} / \mathrm{L}$. Boron concentration in eight samples of subsurface drainwater ranged from 200 to $3,400 \mu \mathrm{g} / \mathrm{L}$.

The highest concentrations of boron in biota were found in plant samples. A sago pondweed sample had a boron concentration of $370 \mu \mathrm{g} / \mathrm{g}$. Levels of boron in the rooted aquatic plants bulrush and sorrel ranged from 40 to $130 \mu \mathrm{g} / \mathrm{g}$ (mean $68.6 \mu \mathrm{g} / \mathrm{g}$ ). Concentrations in samples from the three drainwateraffected sites were higher (61 to $130 \mu \mathrm{g} / \mathrm{g}$; mean 81.3 $\mu \mathrm{g} / \mathrm{g}$ ) than those from the reference sites (40 to 48 $\mu \mathrm{g} / \mathrm{g}$; mean $43.0 \mu \mathrm{g} / \mathrm{g}$ ). (In this report, a reference site is defined as a site unaffected by agricultural drainwater.) Smith and Anders (1989) demonstrated adverse effects on mallard ducklings as a result of maternal and (or) direct post-hatch exposure to dietary boron at concentrations within this range.

Organochlorine pesticide residues were detected in bottom sediment at concentrations approaching those found in 1977 (Eccles, 1979). DDT use in the United States was banned in 1972. Although no DDT was detected in the 1986-87 reconnaissance investigation, its metabolites DDD and DDE were found at concentrations as high as $64 \mu \mathrm{g} / \mathrm{kg}$ (DDE) in bottom sediment of the Alamo River at its outlet, and 24 $\mu \mathrm{g} / \mathrm{kg}$ (DDD) in bottom sediment of the New River at the international boundary. Eccles (1979) reported $110 \mu \mathrm{g} / \mathrm{kg}$ DDE in bottom sediment at Trifolium Drain 1 in 1977, in comparison with $41 \mu \mathrm{g} / \mathrm{kg}$ in sediment collected for the reconnaissance study in 1986.

Saiki (1990) collected a total of 21 composite samples of four species of fish from the Salton Sea for analysis of trace-element concentrations. The species collected were orangemouth corvina (Cynoscion xanthulus), bairdiella (Bairdiella icistia), sargo (Anisotremus davidsoni), and Mozambique tilapia (Tilapia mossambica). These species represent the major recreational fishery of the Salton Sea as well as a significant food source for fish-eating birds. Arsenic, boron, cobalt, copper, iron, mercury, molybdenum, nickel, lead, vanadium, and zinc were detected, but only selenium was elevated in comparison with levels measured in either the muscle or whole body of saltwater fish from comparable studies outside the Salton Sea. However, the threshold concentration in tissues at which selenium is toxic to saltwater fish remains unknown. Boron concentrations in fish sampled by Saiki (1990) were comparable to those reported by Setmire and others (1990).
Cooke and Bruland (1987) and McCleneghan and others (1981) studied the occurrence and distribution of inorganic and organic selenium species in the Kesterson Reservoir, San Joaquin River, and the Salton Sea. At sites in the Salton Sea, they found a strong density gradient that resulted in anoxic conditions and the presence of hydrogen sulfide below $20 \mathrm{ft}$. Water analyses by Cooke and Bruland (1987) indicated that 58 to 81 percent of the total selenium was in the zero (elemental) state or negative oxidation state in the form of dissolved organic selenides. Organic selenides (minus seleniumcontaining free amino acids) represented 42 to 74 percent, the proportion increasing with depth. Selenite ( +4 oxidation state) represented 33 percent of the total selenium in oxic surface water, but less than 1 percent of the total selenium in anoxic waters. Selenate, $(+6)$, the thermodynamically stable form in oxic water, was not detected.

In 1980, catfish collected from the Alamo and New Rivers as part of the California Toxic Substances Monitoring Program (CTSMP) had concentrations of total DDT in excess of the National Academy of Sciences, National Academy of Engineering (1973) guideline of $1.0 \mathrm{mg} / \mathrm{kg}$ wet weight (McCleneghan and others, 1981). Endrin and HCB (hexachlorobenzene) also were found at levels of concern in fish collected in the Imperial Valley.

Matsui (1989) recently found significant decreases in the number of eggs and larvae of bairdiella and sargo. Also documented in that study were deformities in ichthyoplankton that were attributed to unknown contaminants.

Mora and others (1987) investigated the seasonal variation of body condition and organochlorine pesticide residues in ducks from California and Mexico in 1981-82. Some of the highest DDT and DDE concentrations were detected in pintails collected from the Salton Sea NWR. These levels were comparable to the high levels detected in waterfowl in California by Ohlendorf and Miller (1984). Levels of DDT and DDE in pintails collected from the Imperial Valley were higher than those collected from the Klamath Basin, Sacramento Valley, Sacramento/San Joaquin Delta, and San Joaquin Valley (Ohlendorf and Miller, 1984). Other contaminants-such as dieldrin, polychlorinated biphenyls (PCBs), and $\mathrm{HCB}$ - also were found in higher concentrations in Imperial Valley waterfowl. Concentrations of PCBs and HCB in pintails and shovelers were at levels not known to have any effect on survival or reproduction. However, further sampling was recommended for Imperial 
Valley to determine if DDE concentrations were at potentially harmful levels.

Ohlendorf and Marois (1990) found elevated levels of DDE in eggs of great egret and black-crowned night heron (geometric means of 24 and $8.62 \mu \mathrm{g} / \mathrm{g}$ wet weight, respectively) collected at Salton Sea in 1985. The mean DDE residues in night heron eggs from Salton Sea were significantly higher than those in night heron eggs from Bair Island (San Francisco Bay), Kesterson NWR, and Volta WA. Seventy percent of the night heron eggs collected from Salton Sea exceeded $8 \mu \mathrm{g} / \mathrm{g}$ wet weight, which is the level known to cause decreased reproductive success in the species. Mean selenium concentration in night heron eggs from the Salton Sea were higher than from other sites, but below concentrations associated with adverse reproductive effects.

Researchers at the Lawrence Livermore Laboratory previously found high selenium concentrations in waterfowl wintering in the Imperial Valley (Koranda and others, 1979). Mean concentrations (dry weight) were $15 \mu \mathrm{g} / \mathrm{g}$ in green-winged teal, $15.6 \mu \mathrm{g} / \mathrm{g}$ in shovelers, $11.2 \mu \mathrm{g} / \mathrm{g}$ in pintails, and $49.5 \mu \mathrm{g} / \mathrm{g}$ in ruddy ducks. The concentrations, which were as high as $143.9 \mu \mathrm{g} / \mathrm{g}$, were below or within the range of concentrations ( 22 to $175 \mu \mathrm{g} / \mathrm{g}$ ) found (Ohlendorf and others, 1987) at Kesterson NWR. The Lawrence Livermore Laboratory researchers concluded that waterfowl obtained significantly higher concentrations of nickel, selenium, arsenic, and lead while wintering in the Imperial Valley.

Prey-item and band-recovery data in other studies have shown that black-crowned night herons (Henny and others, 1984) and white-faced ibis (Henny and Herron, 1989) wintering in the Imperial Valley experienced decreased reproductive success when they migrated to their more northerly breeding grounds. It was concluded in both studies that DDE accumulation through food chains in the Imperial Valley was the probable source of the reproductive problems.

\section{CONSIDERATIONS IN DEVELOPING A SAMPLING STRATEGY}

This section presents the conceptual model for the selenium pathway that was used in developing the sampling strategy. On the basis of the 1986-87 reconnaissance investigation (Setmire and others, 1990), selenium was considered the main element of concern in the Imperial Valley. However, concerns about the levels of boron and pesticides also were addressed. Colorado River water, delivered via the All-American Canal for irrigation in the Imperial Valley, contains about $2 \mu \mathrm{g} / \mathrm{L}$ of selenium (Schroeder and others, 1991). This irrigation water is delivered to 160 -acre field plots by a 1,675-mile network of canals throughout Imperial Valley. Water applied to the head of a field percolates through the soil and flows to subsurface drains. The flow rate of water that reaches the drains and discharges from the sumps varies and is dependent on the quantity and timing of irrigation, on soil characteristics, and on spatial distribution of subsurface drains. Part of the water that is applied to fields is lost by evapotranspiration; part (tailwater) runs off directly from fields to drainage ditches; and part remains in the soil and becomes concentrated in soluble salts. Thus, irrigation in an arid environment results in an accumulation of salts in the root zone of a field and (or) in concentration of soluble salts in solution. These salts and concentrated water mix to greater or lesser degrees with water from recent irrigation (including rapid-percolation water, or trench flow, immediately above the drains) and with flow of regional ground water to subsurface drains. Selenium, along with other soluble salts in irrigation water, is concentrated in drainwater. This drainwater is collected in sumps and discharged to drainage ditches that empty into either the New or Alamo Rivers or into the Salton Sea. Eventually, the drainwater flows into the Salton Sea at the delta areas of the New and Alamo Rivers or into major drains (Trifolium and Vail) that discharge directly to the Salton Sea.

In the delta areas of the New and Alamo Rivers and the major drains that discharge directly to the Salton Sea, selenium is believed to be removed from the water by selenate-respiring bacteria. These bacteria reduce the selenium in the inflowing water and in the shallow anaerobic sediment. Uptake of the reduced selenium by benthic organisms, particularly pileworms, may then serve as the basis for a detrital food chain in the Salton Sea that results in selenium bioaccumulation and potentially in biomagnification (the increase in tissue concentration of a bioaccumulated chemical as it passes upward through two or more trophic levels) (fig. 8). Pileworms are consumed by forage fish (bairdiella), which in turn are consumed by fish-eating birds such as the federally endangered California brown pelican.

Lemly and Smith (1987) reported that selenium concentrations in aquatic ecosystems are 2 to 6 times greater in lower consumers (such as invertebrates and forage fish) than in producers (phytoplankton, algae, and vascular plants). They documented biomagnifi- 


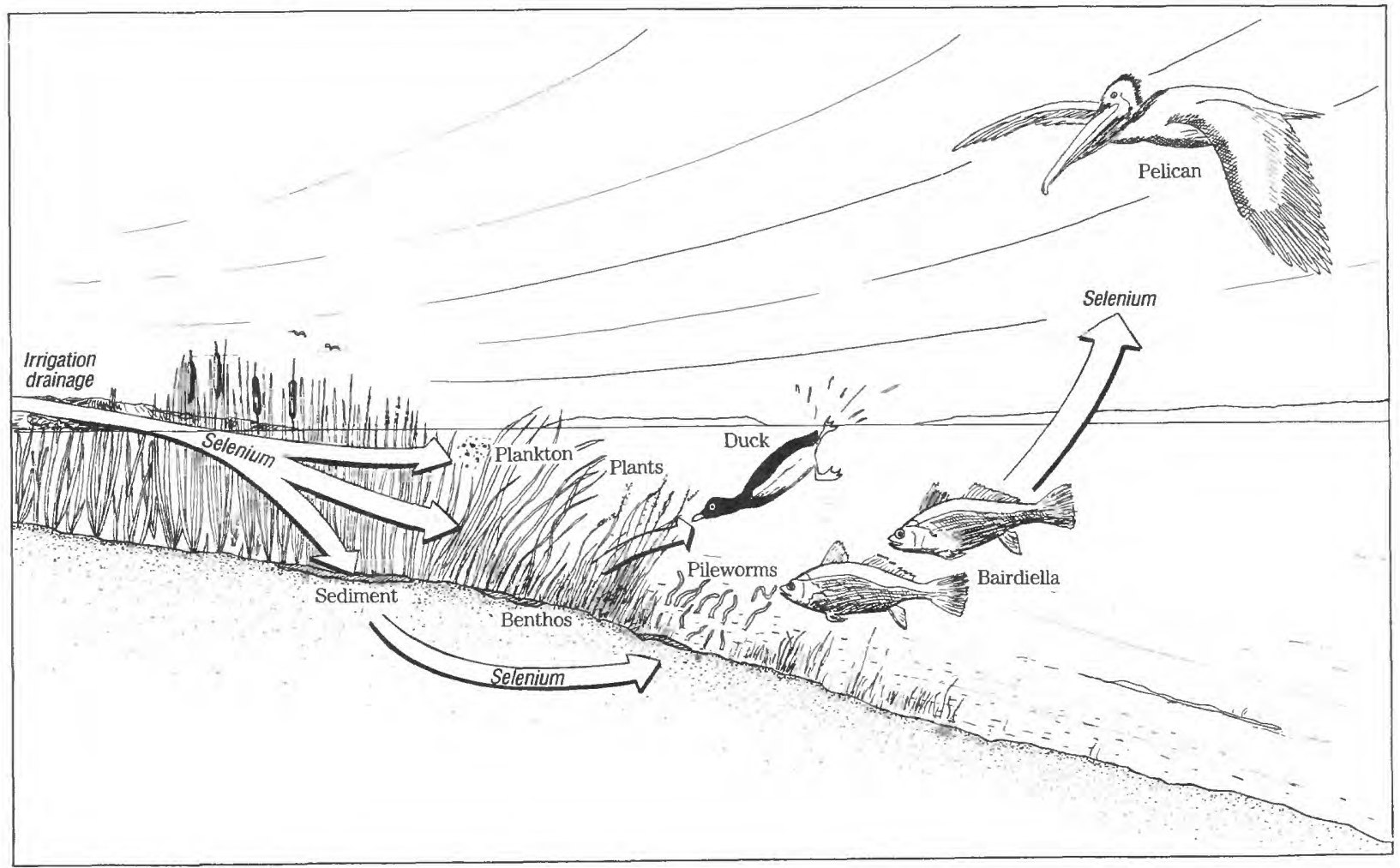

Figure 8. Selenium cycle in the Salton Sea.

cation of selenium in aquatic food chains, although biomagnification has been questioned by others (Kay, 1984). It seems clear, however, that selenium concentrations in animal tissues tend to reflect dietary levels, particularly when the selenium is in an organic form rather than in the oxidized inorganic form (Sharma and Singh, 1983). Biomagnification is important because it can cause top-level consumers, such as fish-eating birds, to receive toxic selenium doses in the diet even though concentrations in water may be low (Lemly and Smith, 1987). Equally important is the risk of toxicity through the detrital food pathway, which will continue despite loss of selenium from the water column as long as contaminated sediment is present, as it is in the Salton Sea. According to Eisler (1985), estuarine and marine organisms usually contain higher concentrations of selenium than do freshwater or terrestrial species. This may also be an important consideration in the Salton Sea because its fauna are predominantly of marine origins (Bayly, 1991) even though its water chemistry is more characteristic of an inland saline lake than of seawater (Wescot, 1990).

DDT contamination in sediment is a consequence of historical usage, soil erosion, and sediment transport. This compound and its metabolites are mobilized by tailwater runoff, which carries soil with sorbed pesticides, or by resuspension of sediment in collector drains and rivers (Setmire and others, 1990).

\section{SAMPLE COLLECTION AND ANALYSIS}

\section{SELECTION OF SAMPLING SITES}

\section{WATER AND BOTTOM SEDIMENT}

Sites for the May 1988 sampling of subsurface irrigation drainwater (table 1; fig. 9) were selected using, as a template, the list of 119 sites sampled in May 1986 by the California Regional Water Quality Control Board. As many of the same sites as could be located were resampled. Several sites from the earlier sampling could not be located.

Soil-sampling sites and sites for monthly monitoring of variation in subsurface drainwater were selected from the May 1988 sampling sites. In consultation with the Imperial Irrigation District (IID), sites (fields) were selected that represent a range of moderate-to-high selenium concentrations and provide areal coverage of the Imperial Valley. For the soil collection, 18 cores were taken from each field. Sites within the field were located at the head of the field where irrigation water is applied, at the center, and 


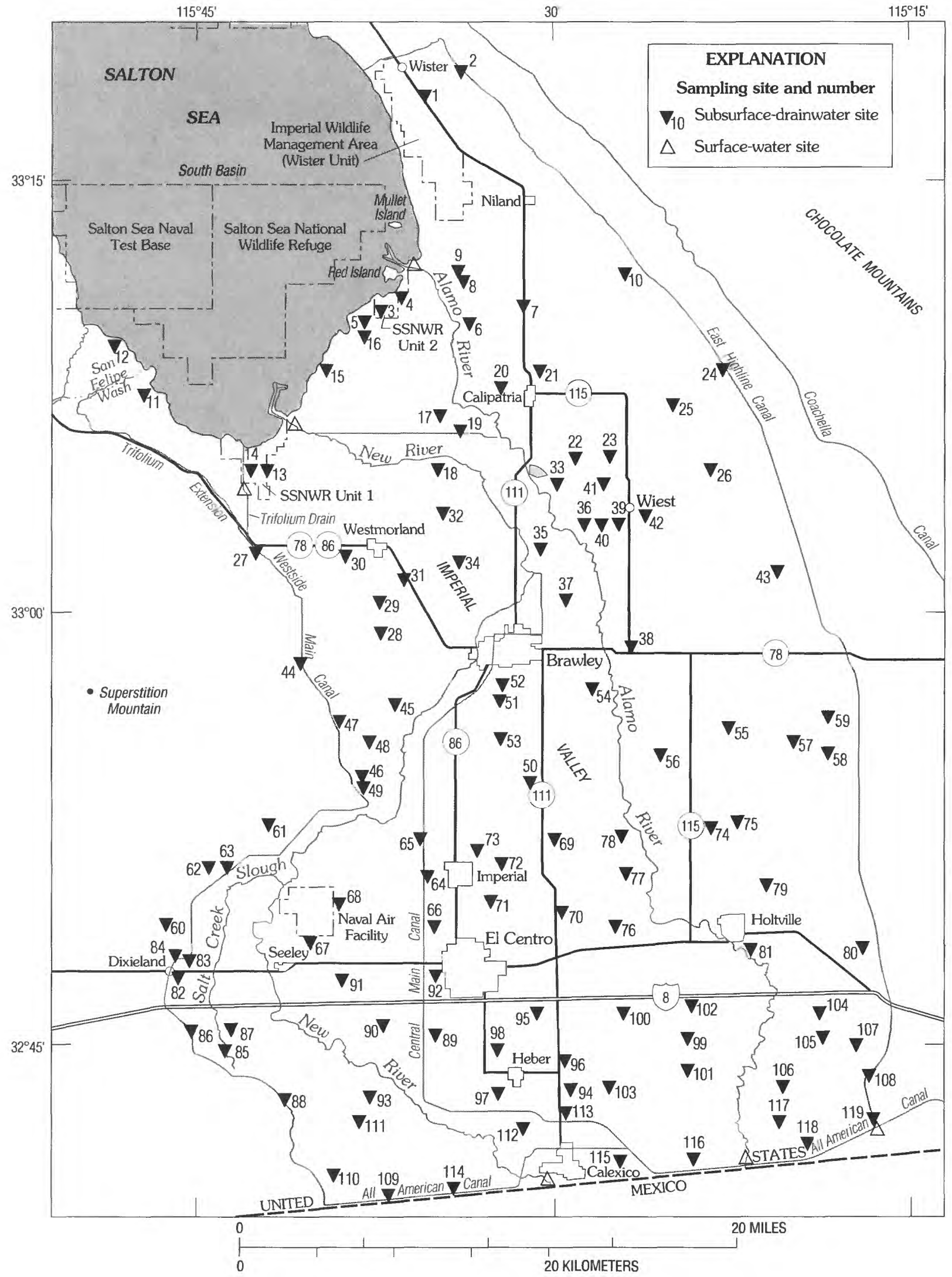

Figure 9. Subsurface-drainwater and surface-water sampling sites in the study area. 
Table 1. Subsurface-drainwater sampling sites in the Imperial Valley

[Location of sites shown in figure 9. Local identifier is Imperial Irrigation District designation]

\begin{tabular}{|c|c|c|c|c|c|c|c|}
\hline $\begin{array}{l}\text { Site } \\
\text { No. }\end{array}$ & $\begin{array}{c}\text { Local } \\
\text { identifier }\end{array}$ & $\begin{array}{c}\text { Latitude } \\
\text { (north) }\end{array}$ & $\begin{array}{l}\text { Longitude } \\
\text { (west) }\end{array}$ & $\begin{array}{l}\text { Site } \\
\text { No. }\end{array}$ & $\begin{array}{c}\text { Local } \\
\text { identifier }\end{array}$ & $\begin{array}{c}\text { Latitude } \\
\text { (north) }\end{array}$ & $\begin{array}{l}\text { Longitude } \\
\text { (west) }\end{array}$ \\
\hline 1 & S-403 & $33^{\circ} 18^{\prime} 02^{\prime \prime}$ & $115^{\circ} 35^{\prime} 22^{\prime \prime}$ & 44 & S-230 & $32^{\circ} 58^{\prime} 23^{\prime \prime}$ & $115^{\circ} 40^{\prime} 31^{\prime \prime}$ \\
\hline 2 & TD-2907 & $33^{\circ} 18^{\prime} 55^{\prime \prime}$ & $115^{\circ} 33^{\prime} 40^{\prime \prime}$ & 45 & S-55 & $32^{\circ} 57^{\prime} 00^{\prime \prime}$ & $115^{\circ} 36^{\prime} 40^{\prime \prime}$ \\
\hline 3 & SS-4 & $33^{\circ} 10^{\prime} 33^{\prime \prime}$ & $115^{\circ} 37^{\prime} 09^{\prime \prime}$ & 46 & S-256 & $32^{\circ} 54^{\prime} 25^{\prime \prime}$ & $115^{\circ} 38^{\prime} 00^{\prime \prime}$ \\
\hline 4 & S-38 & $33^{\circ} 10^{\prime} 58^{\prime \prime}$ & $115^{\circ} 36^{\prime} 15^{\prime \prime}$ & 47 & S-295 & $32^{\circ} 56^{\prime} 17^{\prime \prime}$ & $115^{\circ} 38^{\prime} 58^{\prime \prime}$ \\
\hline 5 & S-45 & $33^{\circ} 10^{\prime} 10^{\prime \prime}$ & $115^{\circ} 37^{\prime} 50^{\prime \prime}$ & 48 & S-112 & $32^{\circ} 55^{\prime} 33^{\prime \prime}$ & $115^{\circ} 37^{\prime} 43^{\prime \prime}$ \\
\hline 6 & S-226 & $33^{\circ} 10^{\prime} 06^{\prime \prime}$ & $115^{\circ} 33^{\prime} 21^{\prime \prime}$ & 49 & S-424 & $32^{\circ} 53^{\prime} 55^{\prime \prime}$ & $115^{\circ} 38^{\prime} 00^{\prime \prime}$ \\
\hline 7 & S-269 & $33^{\circ} 10^{\prime} 37^{\prime \prime}$ & $115^{\circ} 31^{\prime} 03^{\prime \prime}$ & 50 & S-154 & $32^{\circ} 53^{\prime} 54^{\prime \prime}$ & $115^{\circ} 31^{\prime} 01^{\prime \prime}$ \\
\hline 8 & S-417 & $33^{\circ} 11^{\prime} 30^{\prime \prime}$ & $115^{\circ} 33^{\prime} 40^{\prime \prime}$ & 51 & S-105 & $32^{\circ} 56^{\prime} 55^{\prime \prime}$ & $115^{\circ} 32^{\prime} 20^{\prime \prime}$ \\
\hline 9 & S-332 & $33^{\circ} 11^{\prime} 57^{\prime \prime \prime}$ & $115^{\circ} 33^{\prime} 39^{\prime \prime}$ & 52 & S-133 & $32^{\circ} 57^{\prime} 25^{\prime \prime}$ & $115^{\circ} 32^{\prime} 10^{\prime \prime}$ \\
\hline 10 & TD-2013 & $33^{\circ} 11^{\prime} 55^{\prime \prime}$ & $115^{\circ} 26^{\prime} 55^{\prime \prime}$ & 53 & S-153 & $32^{\circ} 55^{\prime} 39^{\prime \prime}$ & $115^{\circ} 32^{\prime} 07^{\prime \prime}$ \\
\hline 11 & SS-3 & $33^{\circ} 07^{\prime} 30^{\prime \prime}$ & $115^{\circ} 46^{\prime} 58^{\prime \prime}$ & 54 & S-365 & $32^{\circ} 57^{\prime} 21^{\prime \prime}$ & $115^{\circ} 28^{\prime} 25^{\prime \prime}$ \\
\hline 12 & SS-26 & $33^{\circ} 09^{\prime} 15^{\prime \prime}$ & $115^{\circ} 48^{\prime} 15^{\prime \prime}$ & 55 & TD-2001 & $32^{\circ} 55^{\prime} 55^{\prime \prime}$ & $115^{\circ} 22^{\prime} 59^{\prime \prime}$ \\
\hline 13 & S-219 & $33^{\circ} 04^{\prime} 53^{\prime \prime}$ & $115^{\circ} 41^{\prime} 57^{\prime \prime}$ & 56 & TD-2040 & $32^{\circ} 55^{\prime} 00^{\prime \prime}$ & $115^{\circ} 25^{\prime} 40^{\prime \prime}$ \\
\hline 14 & S-337 & $33^{\circ} 04^{\prime} 55^{\prime \prime}$ & $115^{\circ} 42^{\prime} 30^{\prime \prime}$ & 57 & TD-2554 & $32^{\circ} 55^{\prime} 25^{\prime \prime}$ & $115^{\circ} 20^{\prime} 05^{\prime \prime}$ \\
\hline 15 & SS-11 & $33^{\circ} 08^{\prime} 23^{\prime \prime}$ & $115^{\circ} 39^{\prime} 19^{\prime \prime}$ & 58 & S-322 & $32^{\circ} 54^{\prime} 57^{\prime \prime}$ & $115^{\circ} 18^{\prime} 36^{\prime \prime}$ \\
\hline 16 & $S-43$ & $33^{\circ} 09^{\prime} 42^{\prime \prime}$ & $115^{\circ} 37^{\prime} 48^{\prime \prime}$ & 59 & S-396 & $32^{\circ} 56^{\prime} 16^{\prime \prime}$ & $115^{\circ} 18^{\prime} 36^{\prime \prime}$ \\
\hline 17 & S-57 & $33^{\circ} 06^{\prime} 53^{\prime \prime}$ & $115^{\circ} 34^{\prime} 42^{\prime \prime}$ & 60 & TD-2432 & $32^{\circ} 49^{\prime} 12^{\prime \prime}$ & $115^{\circ} 46^{\prime} 09^{\prime \prime}$ \\
\hline 18 & TD-1829 & $33^{\circ} 04^{\prime} 55^{\prime \prime}$ & $115^{\circ} 34^{\prime} 40^{\prime \prime}$ & 61 & S-70 & $32^{\circ} 52^{\prime} 43^{\prime \prime}$ & $115^{\circ} 41^{\prime} 46^{\prime \prime}$ \\
\hline 19 & S-25 & $33^{\circ} 06^{\prime} 15^{\prime \prime}$ & $115^{\circ} 33^{\prime} 39^{\prime \prime}$ & 62 & S-68 & $32^{\circ} 51^{\prime} 07^{\prime \prime}$ & $115^{\circ} 44^{\prime} 23^{\prime \prime}$ \\
\hline 20 & S-79 & $33^{\circ} 07^{\prime} 30^{\prime \prime}$ & $115^{\circ} 32^{\prime} 33^{\prime \prime}$ & 63 & S-333 & $32^{\circ} 51^{\prime} 06^{\prime \prime}$ & $115^{\circ} 43^{\prime} 35^{\prime \prime}$ \\
\hline 21 & S-119 & $33^{\circ} 08^{\prime} 22^{\prime \prime}$ & $115^{\circ} 30^{\prime} 26^{\prime \prime}$ & 64 & S-110 & $32^{\circ} 50^{\prime} 48^{\prime \prime}$ & $115^{\circ} 35^{\prime} 17^{\prime \prime}$ \\
\hline 22 & S-243 & $33^{\circ} 05^{\prime} 18^{\prime \prime}$ & $115^{\circ} 29^{\prime} 00^{\prime \prime}$ & 65 & S-67 & $32^{\circ} 52^{\prime} 07^{\prime \prime}$ & $115^{\circ} 35^{\prime} 35^{\prime \prime}$ \\
\hline 23 & S-488 & $33^{\circ} 05^{\prime} 18^{\prime \prime}$ & $115^{\circ} 27^{\prime} 26^{\prime \prime}$ & 66 & S-225 & $32^{\circ} 49^{\prime} 04^{\prime \prime}$ & $115^{\circ} 35^{\prime} 09^{\prime \prime}$ \\
\hline 24 & TD-3038 & $33^{\circ} 08^{\prime} 30^{\prime \prime}$ & $115^{\circ} 22^{\prime} 55^{\prime \prime}$ & 67 & S-265 & $32^{\circ} 48^{\prime} 26^{\prime \prime}$ & $115^{\circ} 40^{\prime} 12^{\prime \prime}$ \\
\hline 25 & TD-2715 & $33^{\circ} 07^{\prime} 10^{\prime \prime}$ & $115^{\circ} 24^{\prime} 55^{\prime \prime}$ & 68 & S-398 & $32^{\circ} 49^{\prime} 56^{\prime \prime}$ & $115^{\circ} 39^{\prime} 11^{\prime \prime}$ \\
\hline 26 & TD-147 & $33^{\circ} 04^{\prime} 55^{\prime \prime}$ & $115^{\circ} 23^{\prime} 20^{\prime \prime}$ & 69 & S-148 & $32^{\circ} 52^{\prime} 06^{\prime \prime}$ & $115^{\circ} 30^{\prime} 03^{\prime \prime}$ \\
\hline 27 & S-364 & $33^{\circ} 02^{\prime} 03^{\prime \prime}$ & $115^{\circ} 42^{\prime} 19^{\prime \prime}$ & 70 & TD-1408 & $32^{\circ} 49^{\prime} 30^{\prime \prime}$ & $115^{\circ} 29^{\prime} 46^{\prime \prime}$ \\
\hline 28 & S-28 & $32^{\circ} 59^{\prime} 18^{\prime \prime}$ & $115^{\circ} 37^{\prime} 07^{\prime \prime}$ & 71 & S-234 & $32^{\circ} 49^{\prime} 55^{\prime \prime}$ & $115^{\circ} 32^{\prime} 37^{\prime \prime}$ \\
\hline 29 & S-69 & $33^{\circ} 00^{\prime} 23^{\prime \prime}$ & $115^{\circ} 37^{\prime} 13^{\prime \prime}$ & 72 & S-410 & $32^{\circ} 51^{\prime} 15^{\prime \prime}$ & $115^{\circ} 32^{\prime} 10^{\prime \prime}$ \\
\hline 30 & S-94 & $33^{\circ} 02^{\prime} 12^{\prime \prime}$ & $115^{\circ} 38^{\prime} 45^{\prime \prime}$ & 73 & S-411 & $32^{\circ} 51^{\prime} 40^{\prime \prime}$ & $115^{\circ} 33^{\prime} 10^{\prime \prime}$ \\
\hline 31 & S-127 & $33^{\circ} 01^{\prime} 15^{\prime \prime}$ & $115^{\circ} 36^{\prime} 10^{\prime \prime}$ & 74 & S-2 & $32^{\circ} 52^{\prime} 30^{\prime \prime}$ & $115^{\circ} 23^{\prime} 45^{\prime \prime}$ \\
\hline 32 & S-353 & $33^{\circ} 03^{\prime} 28^{\prime \prime}$ & $115^{\circ} 34^{\prime} 36^{\prime \prime}$ & 75 & S-4 & $32^{\circ} 52^{\prime} 30^{\prime \prime}$ & $115^{\circ} 22^{\prime} 30^{\prime \prime}$ \\
\hline 33 & S-142 & $33^{\circ} 04^{\prime} 26^{\prime \prime}$ & $115^{\circ} 29^{\prime} 39^{\prime \prime}$ & 76 & S-103 & $32^{\circ} 48^{\prime} 55^{\prime \prime}$ & $115^{\circ} 27^{\prime} 23^{\prime \prime}$ \\
\hline 34 & S-175 & $33^{\circ} 01^{\prime} 45^{\prime \prime}$ & $115^{\circ} 33^{\prime} 52^{\prime \prime}$ & 77 & S-247 & $32^{\circ} 50^{\prime} 48^{\prime \prime}$ & $115^{\circ} 27^{\prime} 04^{\prime \prime}$ \\
\hline 35 & S-290 & $33^{\circ} 02^{\prime} 12^{\prime \prime}$ & $115^{\circ} 30^{\prime} 29^{\prime \prime}$ & 78 & S-376 & $32^{\circ} 52^{\prime} 13^{\prime}$ & $115^{\circ} 27^{\prime} 19^{\prime \prime}$ \\
\hline 36 & S-214 & $33^{\circ} 03^{\prime} 04^{\prime \prime}$ & $115^{\circ} 28^{\prime} 44^{\prime \prime}$ & 79 & S-72 & $32^{\circ} 50^{\prime} 21^{\prime \prime}$ & $115^{\circ} 21^{\prime \prime} 16^{\prime \prime}$ \\
\hline 37 & S-385 & $33^{\circ} 00^{\prime} 27^{\prime \prime}$ & $115^{\circ} 29^{\prime} 26^{\prime \prime}$ & 80 & S-169 & $32^{\circ} 48^{\prime} 09^{\prime \prime}$ & $115^{\circ} 17^{\prime} 32^{\prime \prime}$ \\
\hline 38 & S-122 & $32^{\circ} 58^{\prime} 52^{\prime \prime}$ & $115^{\circ} 26^{\prime} 51^{\prime \prime}$ & 81 & S-187 & $32^{\circ} 48^{\prime} 12^{\prime \prime}$ & $115^{\circ} 21^{\prime} 51^{\prime \prime}$ \\
\hline 39 & S-160 & $33^{\circ} 03^{\prime} 05^{\prime \prime}$ & $115^{\circ} 27^{\prime} 25^{\prime \prime}$ & 82 & S-21 & $32^{\circ} 47^{\prime} 29^{\prime \prime}$ & $115^{\circ} 45^{\prime} 52^{\prime \prime}$ \\
\hline 40 & S-212 & $33^{\circ} 03^{\prime} 04^{\prime \prime}$ & $115^{\circ} 27^{\prime} 53^{\prime \prime}$ & 83 & S-22 & $32^{\circ} 47^{\prime} 52^{\prime \prime}$ & $115^{\circ} 45^{\prime} 07^{\prime \prime}$ \\
\hline 41 & S-241 & $33^{\circ} 04^{\prime} 26^{\prime \prime}$ & $115^{\circ} 27^{\prime} 53^{\prime \prime}$ & 84 & S-130 & $32^{\circ} 48^{\prime} 02^{\prime \prime}$ & $115^{\circ} 45^{\prime} 46^{\prime \prime}$ \\
\hline 42 & S-383 & $33^{\circ} 03^{\prime} 33^{\prime \prime}$ & $115^{\circ} 26^{\prime} 21^{\prime \prime}$ & 85 & S-207 & $32^{\circ} 44^{\prime} 40^{\prime \prime}$ & $115^{\circ} 43^{\prime} 47^{\prime \prime}$ \\
\hline 43 & TD-245 & $33^{\circ} 01^{\prime} 20^{\prime \prime}$ & $115^{\circ} 20^{\prime} 40^{\prime \prime}$ & 86 & TD-2939 & $32^{\circ} 42^{\prime} 25^{\prime \prime}$ & $115^{\circ} 45^{\prime} 10^{\prime \prime}$ \\
\hline
\end{tabular}


Table 1. Subsurface-drainwater sampling sites in the Imperial Valley--Continued

\begin{tabular}{|c|c|c|c|c|c|c|c|}
\hline $\begin{array}{l}\text { Site } \\
\text { No. }\end{array}$ & $\begin{array}{c}\text { Local } \\
\text { identifier }\end{array}$ & $\begin{array}{c}\text { Latitude } \\
\text { (north) }\end{array}$ & $\begin{array}{l}\text { Longitude } \\
\text { (west) }\end{array}$ & $\begin{array}{l}\text { Site } \\
\text { No. }\end{array}$ & $\begin{array}{c}\text { Local } \\
\text { identifier }\end{array}$ & $\begin{array}{c}\text { Latitude } \\
\text { (north) }\end{array}$ & $\begin{array}{c}\text { Longitude } \\
\text { (west) }\end{array}$ \\
\hline 87 & S-352 & $32^{\circ} 45^{\prime} 28^{\prime \prime}$ & $115^{\circ} 43^{\prime} 31^{\prime \prime}$ & 104 & S-176 & $32^{\circ} 45^{\prime} 55^{\prime \prime}$ & $115^{\circ} 19^{\prime} 10^{\prime \prime}$ \\
\hline 88 & S-81 & $32^{\circ} 42^{\prime} 59^{\prime \prime}$ & $115^{\circ} 41^{\prime} 10^{\prime \prime}$ & 105 & S-316 & $32^{\circ} 45^{\prime} 04^{\prime \prime}$ & $115^{\circ} 18^{\prime} 59^{\prime \prime}$ \\
\hline 89 & S-113 & $32^{\circ} 45^{\prime} 11^{\prime \prime}$ & $115^{\circ} 35^{\prime} 08^{\prime \prime}$ & 106 & S-336 & $32^{\circ} 43^{\prime} 20^{\prime \prime}$ & $115^{\circ} 20^{\prime} 40^{\prime \prime}$ \\
\hline 90 & S-115 & $32^{\circ} 45^{\prime} 33^{\prime \prime}$ & $115^{\circ} 37^{\prime} 10^{\prime \prime}$ & & & & \\
\hline \multirow[t]{2}{*}{91} & S-242 & $32^{\circ} 47^{\prime} 05^{\prime \prime}$ & $115^{\circ} 38^{\prime} 45^{\prime \prime}$ & 107 & S-386 & $32^{\circ} 44^{\prime} 38^{\prime \prime}$ & $115^{\circ} 17^{\prime} 34^{\prime \prime}$ \\
\hline & & & & 108 & S-393 & $32^{\circ} 44^{\prime} 02^{\prime \prime}$ & $115^{\circ} 16^{\prime} 15^{\prime \prime}$ \\
\hline 92 & S-392 & $32^{\circ} 47^{\prime} 20^{\prime \prime}$ & $115^{\circ} 35^{\prime} 00^{\prime \prime}$ & 109 & $S-60$ & $32^{\circ} 39^{\prime} 26^{\prime \prime}$ & $115^{\circ} 37^{\prime} 10^{\prime \prime}$ \\
\hline 93 & S-423 & $32^{\circ} 42^{\prime} 59^{\prime \prime}$ & $115^{\circ} 37^{\prime} 38^{\prime \prime}$ & 110 & S-344 & $32^{\circ} 40^{\prime} 18^{\prime \prime}$ & $115^{\circ} 39^{\prime} 16^{\prime \prime}$ \\
\hline 94 & S-93 & $32^{\circ} 43^{\prime} 20^{\prime \prime}$ & $115^{\circ} 29^{\prime} 30^{\prime \prime}$ & 111 & S-416 & $32^{\circ} 42^{\prime} 16^{\prime \prime}$ & $115^{\circ} 38^{\prime} 16^{\prime \prime}$ \\
\hline 95 & $S-221$ & $32^{\circ} 45^{\prime} 58^{\prime \prime}$ & $115^{\circ} 30^{\prime} 43^{\prime \prime}$ & & & & \\
\hline \multirow[t]{2}{*}{96} & S-229 & $32^{\circ} 44^{\prime} 14^{\prime \prime}$ & $115^{\circ} 29^{\prime} 43^{\prime \prime}$ & 112 & S-108 & $32^{\circ} 41^{\prime} 58^{\prime \prime}$ & $115^{\circ} 31^{\prime} 25^{\prime \prime}$ \\
\hline & & & & 113 & S-182 & $32^{\circ} 42^{\prime} 29^{\prime \prime}$ & $115^{\circ} 29^{\prime} 48^{\prime \prime}$ \\
\hline 97 & $S-321$ & $32^{\circ} 43^{\prime} 22^{\prime \prime}$ & $115^{\circ} 32^{\prime} 30^{\prime \prime}$ & 114 & $\mathrm{~S}-402$ & $32^{\circ} 39^{\prime} 38^{\prime \prime}$ & $115^{\circ} 34^{\prime} 33^{\prime \prime}$ \\
\hline 98 & S-371 & $32^{\circ} 44^{\prime} 42^{\prime \prime}$ & $115^{\circ} 32^{\prime} 35^{\prime \prime}$ & 115 & S-59 & $32^{\circ} 40^{\prime} 27^{\prime \prime}$ & $115^{\circ} 27^{\prime} 21^{\prime \prime}$ \\
\hline 99 & S-144 & $32^{\circ} 45^{\prime} 04^{\prime \prime}$ & $115^{\circ} 24^{\prime} 43^{\prime \prime}$ & 116 & S-267 & $32^{\circ} 40^{\prime} 45^{\prime \prime}$ & $115^{\circ} 24^{\prime} 26^{\prime \prime}$ \\
\hline 100 & S-164 & $32^{\circ} 45^{\prime} 58^{\prime \prime}$ & $115^{\circ} 27^{\prime} 19^{\prime \prime}$ & & & & \\
\hline 101 & S-202 & $32^{\circ} 43^{\prime} 46^{\prime \prime}$ & $115^{\circ} 24^{\prime} 44^{\prime \prime}$ & 117 & S-14 & $32^{\circ} 42^{\prime} 03^{\prime \prime}$ & $115^{\circ} 20^{\prime} 57^{\prime \prime}$ \\
\hline 102 & S-368 & $32^{\circ} 46^{\prime} 19^{\prime \prime}$ & $115^{\circ} 24^{\prime} 41^{\prime \prime}$ & 118 & $S-360$ & $32^{\circ} 41^{\prime} 19^{\prime \prime}$ & $115^{\circ} 29^{\prime} 40^{\prime \prime}$ \\
\hline 103 & S-408 & $32^{\circ} 43^{\prime} 20^{\prime \prime}$ & $115^{\circ} 27^{\prime} 50^{\prime \prime}$ & 119 & S-222 & $32^{\circ} 42^{\prime} 19^{\prime \prime}$ & $115^{\circ} 15^{\prime} 58^{\prime \prime}$ \\
\hline
\end{tabular}

at the tail where the discharge sump is located. (See "Physical Characteristics of Fields" section.) At each of these sites, samples at 3 and $6 \mathrm{ft}$ below the surface were collected at three points: (1) adjacent to the subsurface drain, (2) at the midpoint between the subsurface drains, and (3) midway between the midpoint and the subsurface drain (that is, one-fourth the distance between the drains). The sumps from these 15 fields also were sampled monthly for the investigation of time-series variation in concentrations of selected constituents.

From the 15 soil-sample sites, 3 sites were selected for installation of multiple-depth wells and suction-cup lysimeters to discern regional patterns in ground-water quality. Geographic representation was the main criterion used for selection of these three sites. A site was selected in each of the northern, middle, and southern parts of the Imperial Valley. Because IID owns and maintains access roads to fields and sumps in the Imperial Valley, the wells and lysimeters were installed adjacent to these roads. In this report, site numbers are cross referenced (see table 1) to IID sump and tile-drain designations. (This limited ground-water investigation, which was not part of the original Department of the Interior workplan, was funded in cooperation with the California Regional Water Quality Control Board, Colorado River Basin Region, which has jurisdiction over the Coachella and Imperial Valleys.)
The northern well and lysimeter site (site 8, fig. 9) is about 4 mi east of the Salton Sea in an area where geothermal development is prevalent. The downgradient (tail) corner of the field, near the outlet sump, S-417, was selected for well installation. Several problems were encountered in locating the wells and lysimeters. The first was insufficient space for the drill rig and tender on the south side of the drainage ditch. Because of this limitation, the wells were placed on the north side of the ditch. Water quality in these wells potentially is influenced not only by regional ground water and by water from the nearby fields, but also may be influenced by water in the drainage ditch and by water in adjacent commercial fish ponds (filled with Colorado River water). Because no drilling mud was needed for lysimeter holes, the lysimeters were placed on the south side of the drainage ditch and as close to the edge of the field as possible without interfering with farming operations. The collector drain for this field is located at the west end of the field and passes under the ditch to the sump.

The middle well and lysimeter site (site 50, fig. 9) is northeast of $\mathrm{El} \mathrm{Centro} \mathrm{in} \mathrm{an} \mathrm{area} \mathrm{that} \mathrm{once} \mathrm{(through}$ the early 1900's) was Mesquite Lake. The lysimeters were located adjacent to sump S-154 at the southwest corner of the field. Again, because of space and access limitations, the wells were located south of the sump across from an east-to-west drainage ditch, east 
of a north-to-south drainage ditch, and adjacent to a shallow duck (sport) pond to the east.

The southern well and lysimeter site (site 98, fig. 9), is southeast of El Centro. The lysimeters were located adjacent to sump S-371 at the northeast corner of the field. East of the field is a drainage ditch, oriented north-to-south, to which the sump discharges. The wells were located across from the sump east of the drainage ditch on an elevated dirt access road in an area between the ditch and an irrigation canal. During drilling of the lysimeter hole, the sides of the hole kept caving in because of the coarseness of the soil and a high water table. On the basis of data from the lysimeters, it is evident that the water quality is strongly influenced by tailwater runoff and (or) irrigation water that has had little contact with salts from the field.

Site selection for the Alamo River delta sampling was made in the field. Sites were located on a USGS quadrangle map using Loran $\mathrm{C}$ coordinates, the topography of the surrounding land, and prominent local features. Beginning in the Alamo River at Garst Road, immediately upstream of the Salton Sea, measurements of specific conductance, $\mathrm{pH}$, temperature, and dissolved oxygen initially were made about every $500 \mathrm{ft}$. Measurements and sampling were performed at increasingly shorter intervals near the mouth of the Alamo River. Sample and measurement sites also were selected to determine any areal distribution of selenium in the bottom sediments and associated changes in the water column as indicated by density, thermal, or oxygen stratification. Field measurements of specific conductance, $\mathrm{pH}$, temperature, and dissolved-oxygen concentration were made in vertical profiles at all sites.

\section{BIOTA}

The biological sampling sites (fig. 10) were selected to answer each specific objective of the study (see "Purpose and Scope" section). Because these objectives were varied and because samples such as waterfowl are difficult to collect at one location, a total of 39 sites were sampled during 1988-90 (table 2). Sampling was determined largely by availability of organisms and by logistics. The sampling sites include three major habitats: (1) the saline Salton Sea, (2) drains and rivers affected by agricultural drainwater, and (3) creeks not significantly affected by agricultural drainwater. The sampling sites for each species discussed below are given in table 3 in the "Sampling Methods" section that follows.
Sampling sites for algae were selected to be uniformly distributed around the Salton Sea shoreline to determine any significant differences in bioaccumulation of selected drainwater contaminants. Cattails were sampled at five freshwater sites to determine if bioaccumulation in vegetation differed between drains and natural creeks.

Aquatic invertebrates were collected at several locations in deltas of major drains and rivers at the south end of the Salton Sea. These psuedoestuarine sites (where freshwater meets saline water) are very significant feeding or foraging areas for many species of birds. Sampling sites for indigenous Asiatic river clams were selected, subject to availability, in five drains around the Salton Sea, to determine any bioaccumulation differences among drains. Clams also were collected in the lower Colorado River for use in an in situ bioassay. One other invertebrate, crayfish, was collected near the mouths of the New and Alamo Rivers to assess differences in bioaccumulation between these two rivers.

Two species of small forage fish, mosquitofish and sailfin molly, were collected at five sites to determine differences in bioaccumulation between drains and natural creeks. One composite mudsucker sample was taken at the New River delta to supplement food chain bioaccumulation data. Bairdiella, larger forage fish, were sampled at the edge of the Salton Sea near Unit I of the Salton Sea NWR. These fish were sampled because they are important in the food chain and are consumed by fish-eating birds throughout the Salton Sea.

Bullfrogs were sampled only from the Alamo River because of limited availability at other sites. Bullfrogs are good indicators of bioaccumulation because they are carnivorous and represent a high trophic level near the top of one of the freshwater food chains. Spiny softshell turtles, which also are near the top of a food chain, were collected at two drain sites to determine contaminant bioaccumulation.

Although sample site selection for birds was based on the specific objective being addressed, bird availability was a more realistic criterion. Because most birds are highly mobile and can feed in many different locations and habitats, particular sample sites do not necessarily reflect local contaminant conditions. This statement applies to a greater degree to migratory birds. To determine bioaccumulation rates for selected drainwater contaminants in migratory birds wintering at the Salton Sea, ruddy ducks were 


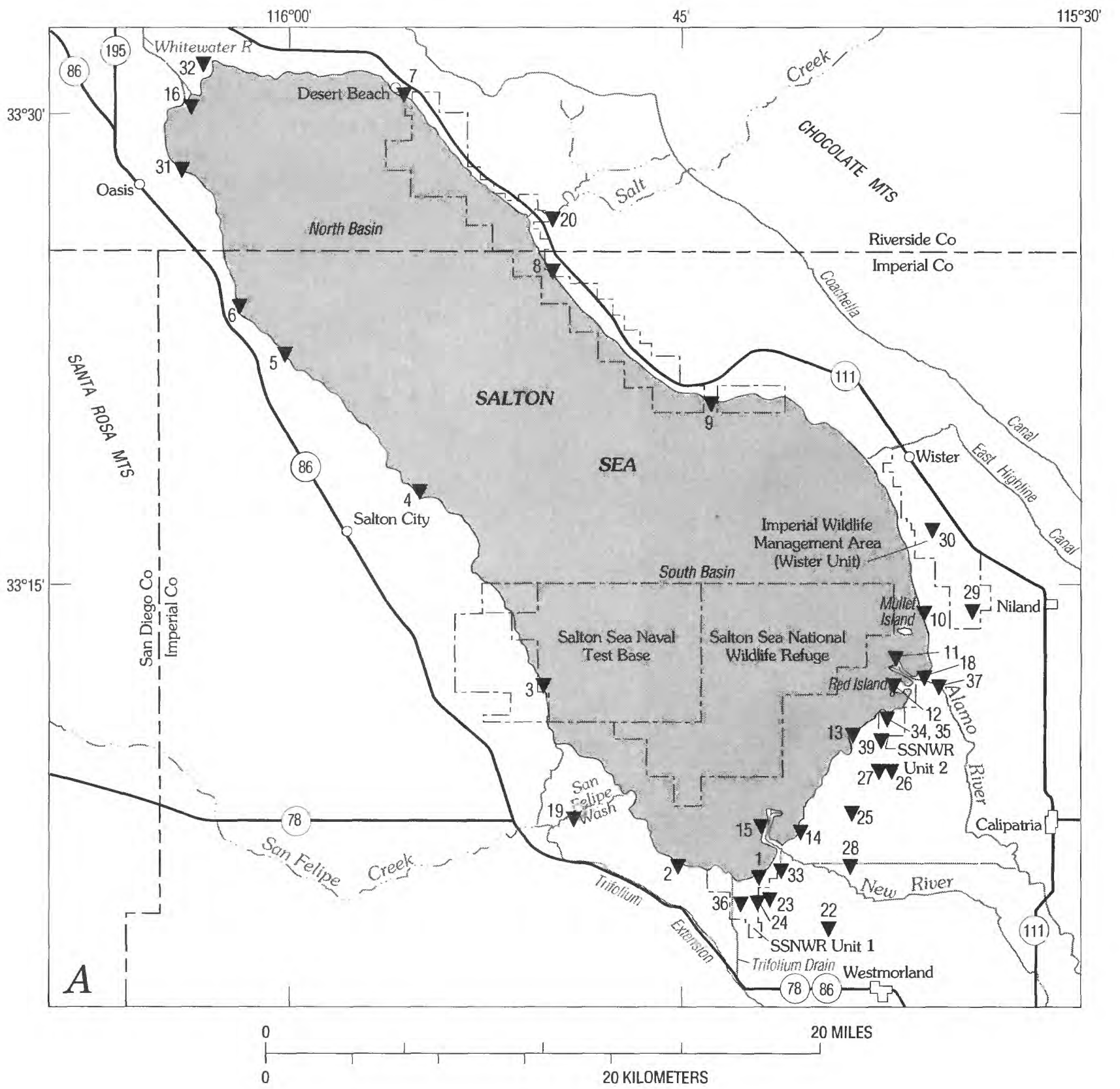

\section{EXPLANATION}

36 Biological sampling site and number - In tables, site numbers are preceded by the letter " $\mathrm{B}$ "

Figure 10. Blological sampling sites in the study area. A, Salton Sea. B, Imperial Valley area. C, Colorado River near Palo Verde. 


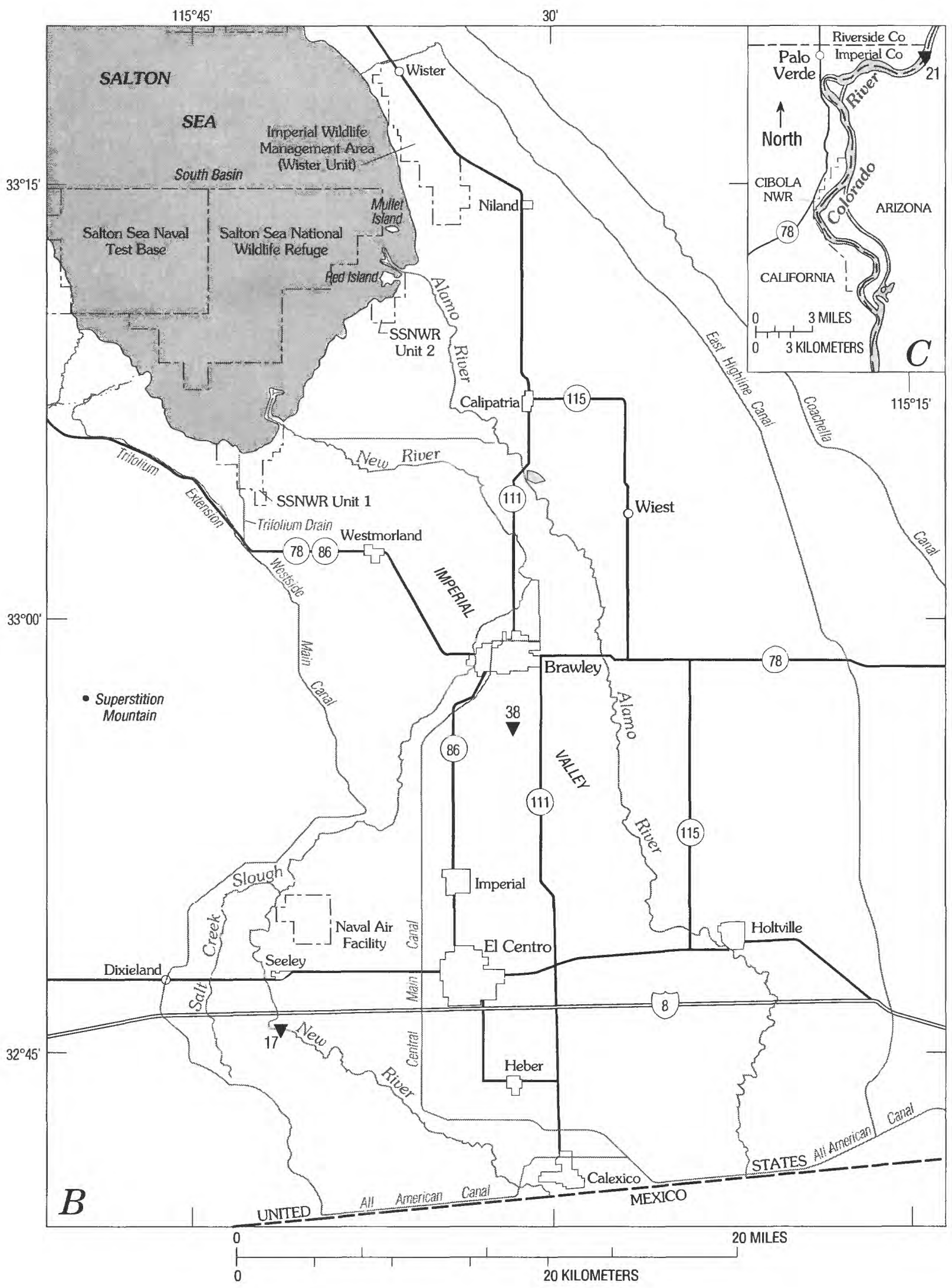

Figure 10. Continued. 
Table 2. Biological sampling sites and constituents analyzed

[Location of sites shown in figure 10. Constituent: TE, trace elements; OC, organochlorine pesticides]

\begin{tabular}{|c|c|c|c|c|c|}
\hline $\begin{array}{l}\text { Site } \\
\text { No. }\end{array}$ & $\begin{array}{l}\text { Description } \\
\text { or designation }\end{array}$ & Constituents & $\begin{array}{l}\text { Site } \\
\text { No. }\end{array}$ & $\begin{array}{l}\text { Description } \\
\text { or designation }\end{array}$ & Constituents \\
\hline \multicolumn{3}{|c|}{ Salton Sea } & \multicolumn{3}{|c|}{ Drainwater Ditches } \\
\hline B1 & $\begin{array}{l}\text { Salton Sea National } \\
\text { Wildlife Refuge Unit } 1\end{array}$ & TE, OC & $\begin{array}{l}\text { B22 } \\
\text { B23 }\end{array}$ & $\begin{array}{l}\text { Trifolium } 5 \\
\text { Trifolium } 13\end{array}$ & $\begin{array}{l}\mathrm{OC} \\
\mathrm{TE}, \mathrm{OC}\end{array}$ \\
\hline B2 & Poe Road & $\mathrm{TE}$ & B24 & Trifolium 14 & TE, OC \\
\hline B3 & U.S. Navy Test Base & TE & $\mathrm{B} 25$ & Vail Cutoff & TE, OC \\
\hline B4 & Salton City & TE & B26 & Vail 4 & TE, OC \\
\hline B5 & Salton Sea Beach & $\mathrm{TE}$ & $\mathrm{B} 27$ & Vail 4A & TE, OC \\
\hline B6 & Desert Shores & $\mathrm{TE}$ & B28 & Vail Drain at New River & $\mathrm{OC}$ \\
\hline B7 & Desert Beach & TE & B29 & S Lateral & TE, OC \\
\hline B8 & Bob's Playa River Marina & $\mathrm{TE}$ & B30 & Z Lateral & TE, OC \\
\hline B9 & Bombay Beach & TE & B31 & 81st Street & TE, OC \\
\hline $\mathrm{B} 10$ & S Drain Outlet & TE, OC & B32 & Johnson Street & TE, OC \\
\hline $\begin{array}{l}\text { B11 } \\
\text { B12 }\end{array}$ & $\begin{array}{l}\text { Alamo River delta } \\
\text { Red Hill Marina }\end{array}$ & $\begin{array}{l}\text { TE, OC } \\
\text { TE }\end{array}$ & \multicolumn{3}{|c|}{ Freshwater Impoundments } \\
\hline B13 & Obsidian Butte & TE, OC & \multirow{5}{*}{$\begin{array}{l}\text { B33 } \\
\text { B34 } \\
\text { B35 } \\
\text { B36 } \\
\text { B37 }\end{array}$} & \multirow{5}{*}{$\begin{array}{l}\text { Shady Acres Duck Club } \\
\text { RH Pond } \\
\text { HQ Pond } \\
\text { Reidman Pond } \\
\text { Hazard Pond }\end{array}$} & \multirow{5}{*}{$\begin{array}{l}\text { TE, OC } \\
\text { TE, OC } \\
\text { TE, OC } \\
\text { TE, OC } \\
\text { TE, OC }\end{array}$} \\
\hline B14 & Bowles Road & $\mathrm{TE}$ & & & \\
\hline B15 & New River delta & TE, OC & & & \\
\hline B16 & Whitewater River delta & OC & & & \\
\hline \multicolumn{3}{|c|}{ Rivers and Creeks } & & & \\
\hline B17 & New River at Rio Bend & TE, OC & \multicolumn{3}{|c|}{ Imperial Valley } \\
\hline B18 & Alamo River at Garst Road & TE, OC & B38 & South Brawley & TE, OC \\
\hline B19 & San Felipe Creek & TE, OC & B39 & McKendry Road & TE, OC \\
\hline B20 & Salt Creek & TE, OC & & & \\
\hline $\mathrm{B} 21$ & Colorado River at Palo Verde & TE, OC & & & \\
\hline
\end{tabular}

collected on their arrival in the autumn, again in the winter, and finally in early spring prior to their departure.

Sampling of resident birds-including the endangered Yuma clapper rail (a salvaged specimen), the black-necked stilt, and the American coot-provided information on local drainwater contaminant conditions. Because these birds have limited home ranges and usually are not migratory, they are likely to better reflect local drainwater-contaminant concentrations in comparison with wintering migratory birds.

Black-necked stilt eggs, juveniles, and adults were sampled extensively throughout the southern part of the Salton Sea and the Imperial Valley. Most stilts are residents of the Salton Sea area, and body burdens probably reflect drainwater-contaminant conditions in both the Salton Sea and the adjacent Imperial Valley.

American coots in the Imperial Valley feed mostly on submergent vegetation in freshwater impound- ments not usually affected by drainwater; therefore, contaminant burdens of coots were not expected to be as high as those of species from habitats directly affected by drainwater. For this reason, only one site was selected for sampling coots.

\section{SAMPLING METHODS}

\section{WATER AND BOTTOM SEDIMENT}

Samples for subsurface drainwater were collected from IID sumps throughout the Imperial Valley. The sump pump was manually activated, and the sample was collected in a plastic bucket or churn splitter from the outflow pipe to the drainage ditch. Discharge was calculated using the rise in the float stick per unit time and the diameter (90 in.) of the sump. For the May 1988 sampling, 108 sumps were sampled throughout the Imperial Valley. Sites were divided into two sampling categories: Sample schedule $\mathrm{A}$ included analyses and (or) measurements 
for specific conductance, $\mathrm{pH}$, temperature, alkalinity, chloride, and selenium; schedule B included these measurements plus analyses for tritium, hydrogen and oxygen stable isotopes, boron, arsenic, nitrogen (ammonia and nitrite plus nitrate), major ions, iron, manganese, molybdenum, and vanadium (Schroeder and others, 1993, table 2).

Monthly water samples were collected during the 1989 water year from six surface-water sites (fig. 9): New River at international boundary at Calexico, New River at outlet to the Salton Sea, Alamo River at international boundary, Alamo River at outlet to the Salton Sea, Trifolium Drain 1, and the south end of the East Highline Canal. The monthly samples included analyses and (or) measurements for specific conductance, $\mathrm{pH}$, temperature, alkalinity, dissolved solids, dissolved major ions and selected trace elements, and dissolved nutrients; quarterly samples included analyses of both filtered (dissolved) and unfiltered (total) samples (Schroeder and others, 1993, table 5). In addition, periodic samples were collected to determine hydrogen and oxygen stable-isotope ratios. Monthly samples for dissolved constituents were collected at the centroid of flow. Quarterly samples were collected by hand and rope with either a DH-48 or DH-59 depth-integrating sampler using the equal-width-increment method and composited in a churn splitter.

Monthly and quarterly samples also were collected from 15 sumps throughout the Imperial Valley, a subset of the sumps sampled during May 1988 (Schroeder and others, 1993, table 4). In a manner similar to that of the May 1988 sampling, subsurface drainwater was collected from the sumps by manually activating the float switch and obtaining the water from the outflow pipe to the drainage ditch.

Samples of shallow ground water were collected at three sites in the Imperial Valley, a further subset of the 15 fields sampled monthly. Samples were collected both from shallow lysimeters and multipledepth wells for analysis of specific conductance, $\mathrm{pH}$, temperature, alkalinity, dissolved solids, dissolved major ions and selected trace elements, dissolved nutrients, tritium, and hydrogen and oxygen isotopes. A few select samples were collected for analysis of ${ }^{13} \mathrm{C} /{ }^{12} \mathrm{C}$ ratio, ${ }^{15} \mathrm{~N} /{ }^{14} \mathrm{~N}$ ratio, and ${ }^{34} \mathrm{~S} /{ }^{32} \mathrm{~S}$ ratio, along with the percentage of carbon-14 (Schroeder and others, 1993, table 10). The lysimeters were sampled by first setting a vacuum and then, as much as several weeks later, applying nitrogen gas to force the water sample from the lysimeter cup to the land surface. Water from deeper artesian wells at the northern and central sites was collected from the flowing well. At the remainder of the wells, water samples were collected using either a Bennet pump or small peristaltic pump after evacuating several well-casing volumes or following recovery of the well after complete evacuation of the water.

Water in and near the delta of the Alamo River was sampled three times. Where depth permitted, samples were collected using a modified Van Dorn sampler. Several of the sites in the embayments on the southern end of the Salton Sea were less than 1.0 $\mathrm{ft}$ deep, preventing use of the sampler. At those sites, water was collected using a wide-mouthed glass bottle. Bottom-sediment samples were collected using either an Ekman Dredge or a piston corer. All samples were collected from an airboat furnished by Salton Sea NWR personnel. Water samples were collected for analysis of dissolved selenium, arsenic, boron, and isotopes of hydrogen and oxygen. Field measurements were made for specific conductance, $\mathrm{pH}$, temperature, and dissolved-oxygen concentration. These measurements were made using a multiparameter unit that was calibrated each day in the field and checked against standards at the end of the day. After the August 1988 sampling trip, subsequent field measurements for dissolved-oxygen concentration and percent saturation were made using an oximeter with an internal microprocessor for salinity compensation. A salinity-correction factor was applied to earlier oxygen readings in calculating the oxygen saturation.

Selected cores were collected in PVC tubes from the Alamo River delta and in the drainage ditch across from sump $S-417$ by physically pushing the tubes into the sediment. The cores were vertically extruded in $2-\mathrm{cm}$ [0.8 in.] segments and placed in a $\mathrm{N}_{2}$-pressurized squeezer that expressed the pore water through a $0.45-\mu \mathrm{m}$ sterile filter directly into collection syringes.

\section{BIOTA}

Samples of biota were collected from 39 sites (table 2; fig. 10) representing the Salton Sea, rivers and creeks, drainwater ditches, freshwater impoundments, and the Imperial Valley to determine the effect of irrigation drainwater on biota. Samples of biota represented various trophic levels and included emergent and submergent vegetation, aquatic invertebrates, fish, amphibians, reptiles, and birds. The species collected and sample types submitted for contaminant analyses during this 3-year detailed study are given in 
table 3. The occurrence of a particular species at any given site was highly variable because sites presented different habitats. Samples were collected, processed, stored, and later shipped in accordance with procedures established by the U.S. Fish and Wildlife Service $(1984,1990$ a).

Algae were collected by hand from rocks or wood piers at the shoreline. Samples of filamentous green algae (Chaetomorpha sp.) and tubular green algae (Enteromorpha sp.), both of which are incidentally consumed by water birds, were collected (along with one sample of unidentified benthic blue-green algae) from 14 sites at various shoreline locations around the Salton Sea. Vegetation was collected from agricultural drainage ditches and from the Salton Sea shorelines with rocky substrate at locations surrounding the Salton Sea. Periphyton was collected and submitted as one composite sample. Algae, which are primary producers and form the base of most food chains, represent one of the lower trophic levels at which initial bioaccumulation of some drainwater contaminants occurs. Common cattail, the only emergent aquatic plant collected as part of the detailed study, was collected from agricultural drainage ditches and creeks. Cattails are utilized for food by several species of waterfowl. Whole-plant samples (including roots) were washed with native water at the collection site to remove excess mud and debris and rewashed with native water prior to being placed in polyethylene bags and frozen.

Aquatic invertebrate collections included Asiatic river clams, crayfish, amphipods, pileworms, and waterboatmen. These invertebrates compose most of the diet of shorebirds and other water birds that feed in the Salton Sea. Pileworms were collected by sieving sediment through fine-mesh screens, and waterboatmen and amphipods were collected using lighted activity traps. In a 1989 sampling, amphipods, pileworms, and waterboatmen were composited as one sample, representing a typical shorebird diet. Crayfish were collected from river/drain sites using small seines, composited whole, and put in chemically cleansed jars. Asiatic river clams were collected from river/drain sites by hand and by sieving sediment through a screen.

In an effort to determine potential bioaccumulation of irrigation drainwater contaminants by invertebrates at river and drain sites, clams collected from the Colorado River near Palo Verde, California, were transplanted to the Alamo River, New River, and Trifolium Drain. The collection areas were side channels of the Colorado River, where water quality is expected to be similar to that of water entering the All-American Canal before it is influenced by irrigation tailwater and subsurface drainwater. Clams were handpicked from bottom sediment and transported in aerated containers to the Salton Sea NWR. An equal number of clams $(n=100)$ then were put into each of three plastic-mesh cages approximately $2 \mathrm{ft}$ $\times 2 \mathrm{ft} \times 4 \mathrm{ft}$ in size. One cage was placed and securely anchored (at each site) in the Alamo River, New River, and Trifolium Drain. Subsamples from each site were collected and analyzed approximately $1,2,4$, and 15 months after placement at these sites. The clam subsamples were shucked and the soft body tissue was submitted for analyses. All aquatic invertebrate samples were placed in chemically cleansed jars immediately following collection, frozen, and shipped on dry ice to analytical laboratories.

Four species of fish (mosquitofish, sailfin molly, longjaw mudsucker, and bairdiella) were collected using long-handled dip nets or small seines. Mosquitofish and sailfin mollies were collected in 1988 and 1990 from rivers, creeks, and drains. Longjaw mudsuckers were collected in 1989 from the New River delta. Bairdiella were collected in 1989 after they had washed onto the shore of the Salton Sea at the S drain outlet near Unit 2 of the Salton Sea NWR. It is suspected that these individuals succumbed to low dissolved oxygen, which commonly occurs in the Salton Sea (Walker, 1961). For small fish, a minimum of 10 fish or $0.9 \mathrm{oz}$ ( 25 grams) of whole fish was composited as a sample and frozen in chemically cleansed jars. The larger bairdiella were wrapped in aluminum foil and placed in polyethylene bags and then frozen.

Two bullfrogs were collected from the Alamo River, and six spiny softshell turtles were collected from two drains on the Salton Sea NWR. Bullfrogs were speared and the carcasses wrapped in aluminum foil and frozen in polyethylene bags. Softshell turtles were trapped in hoop nets baited with commercially prepared tuna. Samples of fat (for organic analyses) and liver tissue (for inorganic analyses) were dissected from the turtles and frozen in chemically cleansed jars. A sample of turtle eggs also was collected from one female for organic analysis.

Several species of water birds, including American coot, black-necked stilt, eared grebe, northern shoveler, ruddy duck, and white-faced ibis were collected using shotguns (with steel shot). These species represent a variety of feeding strategies that include higher trophic levels. Livers and breastmuscle tissue of these species were taken from most 
Table 3. Samples collected at biological sites, 1988-90

[Sites described in table 2. Location of sites is shown in fig. 10]

\begin{tabular}{|c|c|c|c|c|}
\hline \multirow{2}{*}{$\begin{array}{l}\text { Common name } \\
\text { (species) }\end{array}$} & \multirow{2}{*}{ Sample type } & \multirow{2}{*}{ Sites } & \multicolumn{2}{|c|}{ Number of samples analyzed for } \\
\hline & & & $\begin{array}{l}\text { Trace } \\
\text { elements }\end{array}$ & $\begin{array}{l}\text { Organochlorine } \\
\text { pesticides }\end{array}$ \\
\hline \multicolumn{5}{|c|}{ Aquatic Vegetation } \\
\hline $\begin{array}{l}\text { Blue-green algae } \\
\text { (Myxophyceae sp.) }\end{array}$ & Composite & B32 & 1 & 0 \\
\hline $\begin{array}{l}\text { Filamentous green algae } \\
\text { (Chaetomorpha sp.) }\end{array}$ & Composite & $\begin{array}{l}\text { B1,B3,B4,B5,B6,B7,B8, } \\
\text { B9,B12,B13,B14,B31 }\end{array}$ & 12 & 0 \\
\hline $\begin{array}{l}\text { Tubular green algae } \\
\text { (Enteromorpha sp.) }\end{array}$ & Composite & $\begin{array}{l}\text { B1,B2,B3,B4,B5,B6,B7, } \\
\text { B8,B9,B12,B13,B14,B31 }\end{array}$ & 13 & 0 \\
\hline Periphyton & Composite & B1 & 1 & 0 \\
\hline \multicolumn{5}{|c|}{ Emergent Vegetation } \\
\hline $\begin{array}{l}\text { Common cattail } \\
\text { (Typha latifolia) }\end{array}$ & Whole plant & B19,B20,B30,B31,B32 & 5 & 0 \\
\hline \multicolumn{5}{|c|}{ Invertebrates } \\
\hline $\begin{array}{l}\text { Asiatic river clam } \\
\text { (Corbicula fluminea) }\end{array}$ & Soft tissue & $\begin{array}{l}\text { B15,B17,,B18,B21,B23, } \\
\text { B24,B25,B26,B30,B32 }\end{array}$ & 16 & 16 \\
\hline $\begin{array}{l}\text { Crayfish } \\
\text { (Procambaraus clarki) }\end{array}$ & Whole body & $\mathrm{B} 11, \mathrm{~B} 15, \mathrm{~B} 24$ & 2 & 3 \\
\hline $\begin{array}{l}\text { Pelagic invertebrate } \\
\text { "mixture" (amphipod, } \\
\text { pileworm, waterboatman) }\end{array}$ & Composite & B1,B23 & 1 & 1 \\
\hline $\begin{array}{l}\text { Pileworm } \\
\text { (Nereis succinea) }\end{array}$ & Composite & $\mathrm{B} 1, \mathrm{~B} 11, \mathrm{~B} 27$ & 8 & 2 \\
\hline $\begin{array}{l}\text { Waterboatman } \\
\text { (Corixidae) }\end{array}$ & Composite & B11,B15,B18 & 4 & 3 \\
\hline
\end{tabular}

Fish

Bairdiella

Whole body

B10

5

5

(Bairdiella icistia)

Longjaw mudsucker

Whole body

B15

0

(Gillichthys mirabilis)

Mosquitofish

Whole body

B15,B19,B20,B31,B32

(Gambusia affinis)

Sailfin molly

Whole body

B 17,B19,B20,B30,B31,B32 6

(Poecilia latipinna)

Amphibians and Reptiles

Bullfrog

(Rana catesbeiana)

Spiny softshell turtle

Fat/liver/egg

B 18

2

2

(Trionyx spiniferus)

Whole body

B26,B37

6

7

26 Water Quality, Bottom SedIment, and Blota Assoclated with Irrigation Drainage In the Salton Sea Area, Callfornla 
Table 3. Samples collected at biological sites, 1988-90--Continued

\begin{tabular}{|c|c|c|c|c|}
\hline \multirow{2}{*}{$\begin{array}{l}\text { Common name } \\
\text { (species) }\end{array}$} & \multirow{2}{*}{ Sample type } & \multirow[b]{2}{*}{ Sites } & \multicolumn{2}{|c|}{ Number of samples analyzed for: } \\
\hline & & & $\begin{array}{l}\text { Trace } \\
\text { elements }\end{array}$ & $\begin{array}{l}\text { Organochlorine } \\
\text { pesticides }\end{array}$ \\
\hline \multicolumn{5}{|c|}{ Migratory Birds } \\
\hline $\begin{array}{l}\text { American coot } \\
\text { (Fulica americana) }\end{array}$ & Liver & B25 & 3 & 3 \\
\hline $\begin{array}{l}\text { Black-necked stilt } \\
\text { (Himantopus mexicanus) }\end{array}$ & Carcass/egg & $\begin{array}{l}\mathrm{B} 1, \mathrm{~B} 11, \mathrm{~B} 15, \mathrm{~B} 17, \mathrm{~B} 24, \mathrm{~B} 25 \\
\mathrm{~B} 29, \mathrm{~B} 34, \mathrm{~B} 36, \mathrm{~B} 37, \mathrm{~B} 39\end{array}$ & 147 & 122 \\
\hline \multicolumn{5}{|c|}{ Resident Birds } \\
\hline $\begin{array}{l}\text { Eared grebe } \\
\text { (Podiceps nigricollis) }\end{array}$ & Liver/muscle & B13,B15 & 5 & 5 \\
\hline $\begin{array}{l}\text { Northern shoveler } \\
\text { (Anas clypeata) }\end{array}$ & Liver/muscle & B1,B11,B33,B37 & 25 & 3 \\
\hline $\begin{array}{l}\text { Ruddy duck } \\
\text { (Oxyura jamaicensis) }\end{array}$ & Liver/muscle & B1,B24,B26,B35,B37 & 71 & 26 \\
\hline $\begin{array}{l}\text { White-faced ibis } \\
\text { (Plegadis chihi) }\end{array}$ & Liver/muscle & B38 & 18 & 18 \\
\hline \multicolumn{5}{|c|}{ Endangered Birds } \\
\hline $\begin{array}{l}\text { Yuma clapper rail } \\
\text { (Rallus longirostris } \\
\text { yumanensis) }\end{array}$ & Carcass & B29 & 1 & 0 \\
\hline
\end{tabular}

carcasses, frozen, and submitted for inorganic and organic analyses. Carcasses of black-necked stilts were submitted for inorganic analyses. Eggs from black-necked stilts nesting at the Salton Sea also were collected from many localized areas (neighborhoods) for contaminant analysis. The contents of each egg were harvested, placed in a chemically cleansed jar, and frozen. In addition, a freshly dead Yuma clapper rail (which is federally endangered) was salvaged from the nearby Wister Wildlife Management Area (WMA) and submitted for inorganic analysis.

\section{ANALYTICAL METHODS}

\section{WATER AND BOTTOM SEDIMENT}

All water samples for major ions and trace elements were analyzed by the USGS National Water Quality Laboratory in Arvada, Colorado, using methods documented by Fishman and Friedman (1989). These analyses were subjected to quality-assurance practices described by Friedman and Erdmann (1982). Concentrations of trace elements in bottom-sediment samples from the Alamo River delta area, soil samples from fields, and core samples from drilling were determined by the USGS Geologic Division's Analytical Facility in Denver, Colorado, using methods that were prescribed for the Department of the Interior irrigation studies. Most elements were analyzed by inductively coupled argon-plasma atomicemission spectrometry following complete mineral digestion with strong acids. Arsenic and selenium were analyzed by hydride-generation atomic absorption spectroscopy, mercury was analyzed by coldvapor atomic absorption spectrometry, and boron was analyzed in hot-water extractions.

Water samples for hydrogen and oxygen isotopes, and for tritium concentration, were analyzed by the USGS Isotope Fractionation Project Laboratory in Reston, Virginia. Hydrogen-isotope-ratio analyses were done by the zinc hydrogen-gas generation technique (Kendall and Coplen, 1985). Results are reported in $\delta$ as the deviation in parts per thousand (permil) of the isotope ratio in the sample from the isotope ratio in Vienna Standard Mean Ocean Water (V-SMOW). Oxygen-isotope-ratio analyses were 
Table 4. Summary of laboratories, analyses performed, and mediums analyzed for biological samples

[Analysis: ICP, Inductively coupled plasma scan for trace elements (including boron); AA, Atomic absorption spectroscopy for arsenic, mercury, and selenium; OC, Organochlorine pesticide scan includes DDT, DDE, DDD, dieldrin, hexachlorobenzene, and toxaphene, as well as other compounds (Schroeder and others, 1993, table 21)]

\begin{tabular}{|c|c|c|c|}
\hline Laboratory & Analysis & Year & Medium \\
\hline $\begin{array}{l}\text { Environmental Trace Substances } \\
\text { Research Center }\end{array}$ & ICP, AA & $\begin{array}{l}1988 \\
1989\end{array}$ & $\begin{array}{l}\text { Bird } \\
\text { Vegetation, invertebrate, fish, } \\
\text { amphibian, reptile, bird }\end{array}$ \\
\hline Hazleton Laboratory America & $\mathrm{ICP}, \mathrm{AA}$ & $\begin{array}{l}1988 \\
1989\end{array}$ & $\begin{array}{l}\text { Invertebrate, fish } \\
\text { Bird }\end{array}$ \\
\hline $\begin{array}{l}\text { Mississippi State Chemistry } \\
\text { Laboratory }\end{array}$ & $\mathrm{OC}$ & $\begin{array}{l}1988 \\
1989\end{array}$ & $\begin{array}{l}\text { Bird } \\
\text { Invertebrate, fish, amphibian, } \\
\text { reptile, bird }\end{array}$ \\
\hline Patuxent Analytical Control Facility & $\mathrm{ICP}, \mathrm{AA}, \mathrm{OC}$ & 1990 & Vegetation, invertebrate, fish \\
\hline Texas A\&M Research Foundation & OC & 1988 & Invertebrate, fish, bird \\
\hline $\begin{array}{l}\text { Weyerhauser Analytical and Testing } \\
\text { Services }\end{array}$ & OC & 1987 & Invertebrate, fish, bird \\
\hline
\end{tabular}

done by a $\mathrm{CO}_{2}$-equilibration technique (Epstein and Mayeda, 1953) that yields activities rather than concentrations. Tritium analyses were done by liquidscintillation counting of electrolytically concentrated samples.

Monthly water samples collected from the East Highline Canal (Colorado River water) had selenium concentrations of about $2 \mu \mathrm{g} / \mathrm{L}$ and chloride concentrations of about $100 \mathrm{mg} / \mathrm{L}$. For selenium, the measured concentrations are close to the reporting limit of $1 \mu \mathrm{g} / \mathrm{L}$. In order to more accurately determine the selenium concentration, as well as the $\mathrm{Se} / \mathrm{Cl}$ ratio in irrigation water, water samples from the East Highline Canal (downstream of the diversion from the All-American Canal) were concentrated in the laboratory by evaporation from large open-top glass chromatography jars. The water was stirred throughout evaporation using a magnetic stirrer. About 1 month of evaporation at 30 to $35^{\circ} \mathrm{C}$ was required to reduce water volumes nearly 99 percent (about 100 fold concentration).

Evaporations were carried out in two ways: (1) using untreated water and (2) using water acidified to $\mathrm{pH}$ approximately 3 by addition of nitric acid before evaporation was begun. Low $\mathrm{pH}$ was maintained in the acid-treated samples to prevent formation of calcium carbonate, which began to appear in the untreated water soon after evaporation started. Large quantities of calcium sulfate were formed during the evaporation of both the acidified and untreated water. There is evidence of slight selenium incorporation into the solid phases. The evidence is based on analyses of the calcium carbonate itself and on slightly lower $\mathrm{Se} / \mathrm{Cl}$ ratios in untreated samples in comparison with acidified evaporated samples. Unevaporated and acidified evaporated water has nearly the same $\mathrm{Se} / \mathrm{Cl}$ ratios.

BIOTA

Chemical analysis of biological samples was done at several laboratories under contracts administered by the U.S. Fish and Wildlife Service's Patuxent Analytical Control Facility (PACF), Laurel, Maryland (table 4). Several trace elements were analyzed using an inductively coupled plasma scan, and arsenic and selenium were analyzed by atomic absorption spectrometry (AA) using hydride generation; mercury was analyzed using the AA cold-vapor technique. Organochlorine pesticide and Aroclor (PCB) concentrations were determined by solvent extractions and analysis using gas chromatography. Although variations in these analytical techniques (for example, internal 
Table 5. Acceptable accuracy and precision guidelines, and reporting limits, for chemical analyses of biological samples

[Reporting limits in micrograms per gram (wet weight for organic contaminants, dry weight for inorganic contaminants). Duplicate analyses fall within the region of detection when their average concentration is between 2 and 10 times the limit of detection. If average of duplicate analyses is less than 2 times the limit of detection, no evaluation of precision is made. Duplicate analyses fall within region of quantitation when average concentration is greater than 10 times the limit of detection]

\begin{tabular}{|c|c|c|c|c|}
\hline Contaminant & $\begin{array}{l}\text { Reporting } \\
\text { limit }\end{array}$ & $\begin{array}{l}\text { Region of } \\
\text { detection } \\
\text { (percent) }\end{array}$ & $\begin{array}{l}\text { Recovery } \\
\text { range } \\
\text { (percent) }\end{array}$ & $\begin{array}{l}\text { Region of } \\
\text { quantitation } \\
\text { (percent) }\end{array}$ \\
\hline \multicolumn{5}{|c|}{ Gas Chromatography } \\
\hline DDT, DDD, DDE & 0.10 & 30 & $80-120$ & 15 \\
\hline Toxaphene & .50 & 30 & $80-120$ & 15 \\
\hline \multicolumn{5}{|c|}{ Atomic Absorption Spectroscopy--Hydride Generation } \\
\hline Arsenic & 0.80 & 20 & $80-115$ & 10 \\
\hline Selenium & .20 & 20 & $85-115$ & 10 \\
\hline \multicolumn{5}{|c|}{ Cold Vapor Reduction } \\
\hline Mercury & 0.10 & 20 & $85-115$ & 10 \\
\hline \multicolumn{5}{|c|}{ Inductively Coupled Plasma-Emission Spectroscopy } \\
\hline \multicolumn{5}{|l|}{ Boron } \\
\hline With preconcentration & 4.0 & 30 & $80-120$ & 15 \\
\hline Without preconcentration & 20.0 & 30 & $80-120$ & 15 \\
\hline
\end{tabular}

standards) existed, basic quality-assurance procedures established by the PACF were used by all laboratories in this study. The precision and accuracy guidelines and reporting limits for analyses of biotic samples in the study are summarized in table 5.

\section{AREAL DISTRIBUTION OF SELECTED CONSTITUENTS}

During May 1986, the California Regional Water Quality Control Board (Regional Board) collected water samples from 119 sumps or tile drains at fields in the Imperial Valley to determine the concentration of selected constituents, including selenium and dissolved solids. In May 1988, the USGS sampled as many of these same 119 sites as could be located to determine concentrations of an augmented list of constituents. To determine the comparability of the two data sets, selenium concentrations from the May 1988 sampling were compared with concentrations from the May 1986 sampling (fig. 11). A slope close to $1(0.966)$ and high correlation $\left(r^{2}=0.785, \alpha<0.01\right)$ indicate that selenium concentrations in sumps were about the same in the 1986 and 1988 samples. In general, for those sumps having high concentrations of selenium in 1986, concentrations also were high in 1988, and low concentrations remained low. This lack of change in concentration would seem to indicate that the processes controlling selenium concentrations in subsurface drainwater are fairly uniform over long periods of time.

The location of sites sampled during May 1986 and May 1988 is shown in figure 9. Selenium concentrations for the USGS samples ranged from 3 to $300 \mu \mathrm{g} / \mathrm{L}$, with a median concentration of $24 \mu \mathrm{g} / \mathrm{L}$ and standard deviation of 58 (reflecting a skewed distribution). The areal distribution of selenium concentration in subsurface drainwater (USGS samples) (fig. 12) does not indicate any readily discernible regional pattern. An area of high selenium concentration (greater than $100 \mu \mathrm{g} / \mathrm{L}$ ) is located southeast of the Salton Sea NWR where land-surface altitudes are among the lowest in the Imperial Valley, aside from those areas inundated by the Salton Sea. Other areas of elevated levels of selenium, however, are spread throughout the Imperial Valley, both along the main topographic axis of the valley and on the periphery.

Dissolved-solids concentration (fig. 13) and specific conductance show a distribution similar to that of 


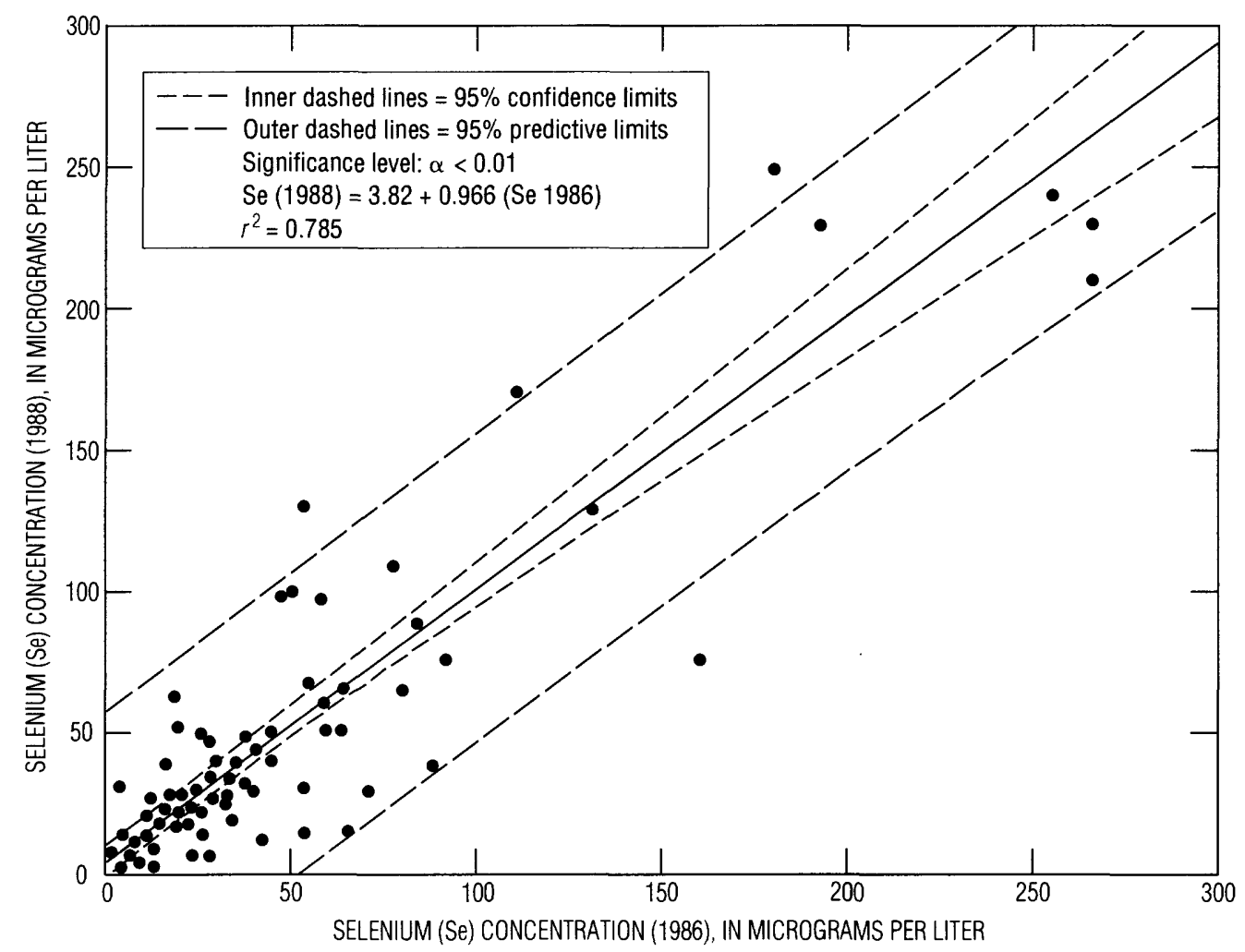

Figure 11. Regression plot of 1988 and 1986 selenium concentrations in subsurfacedrainwater samples collected in the Imperial Valley.

selenium, with the exception of the area bordering the southern end of the Salton Sea. The correlation between specific conductance and selenium for the 1988 data $\left(r^{2}=0.775, \alpha<0.01\right)$ is about the same as the correlation between dissolved-solids concentration and selenium for the 1986 data $\left(r^{2}=0.704\right)$ (California Regional Water Quality Control Board, written commun., 1986). Specific conductance was used for the 1988 data because dissolved-solids concentration was determined at fewer sites, and dissolved-solids concentration was used for the 1986 data because specific conductance was not available. Specific conductance at site 4 (IID sump S-38) was $38,200 \mu \mathrm{S} / \mathrm{cm}$, and selenium concentration was only $15 \mu \mathrm{g} / \mathrm{L}$. At site 15 (IID sump SS-11), specific conductance was $33,800 \mu \mathrm{S}$, and selenium was only 3 $\mu \mathrm{g} / \mathrm{L}$. Both of these sites had high chloride concentrations: 14,000 and $11,000 \mathrm{mg} / \mathrm{L}$, respectively. Apparently, the high dissolved-solids concentrations of the sumps draining these two fields is strongly influenced by water from the Salton Sea, which has a chloride concentration of about $17,000 \mathrm{mg} / \mathrm{L}$ (slightly less near the river outlets at the south end of the Salton Sea). The more reducing environment present along the southern edge of the Salton Sea also could be exerting an influence on the chemistry of these fields; both sites had elevated ammonia concentrations ( 3.2 and $10 \mathrm{mg} / \mathrm{L}$, respectively), and the reducing conditions could affect the concentration of selenium through changes in oxidation state. This effect will be discussed later in more detail.

\section{TEMPORAL VARIATION IN CONCENTRATION OF SELECTED CONSTITUENTS}

Monthly subsurface drainwater samples were collected from August 1988 to August 1989 from 15 fields (previously identified) to determine the temporal variation in constituent concentrations. Temporal variations in selenium concentration and instantaneous discharge, specific conductance, selenium-to-chloride weight ratio, and dissolved-solids concentration during the sampling period for all 15 fields are shown in figure 14. The effect of discharge on selenium concentration for monthly samples collected from 15 sites is shown in this figure. When drainflow increases, selenium concentration decreases (as do chloride and dissolved-solids concentration), and as drainflow decreases, selenium concentration increases. 


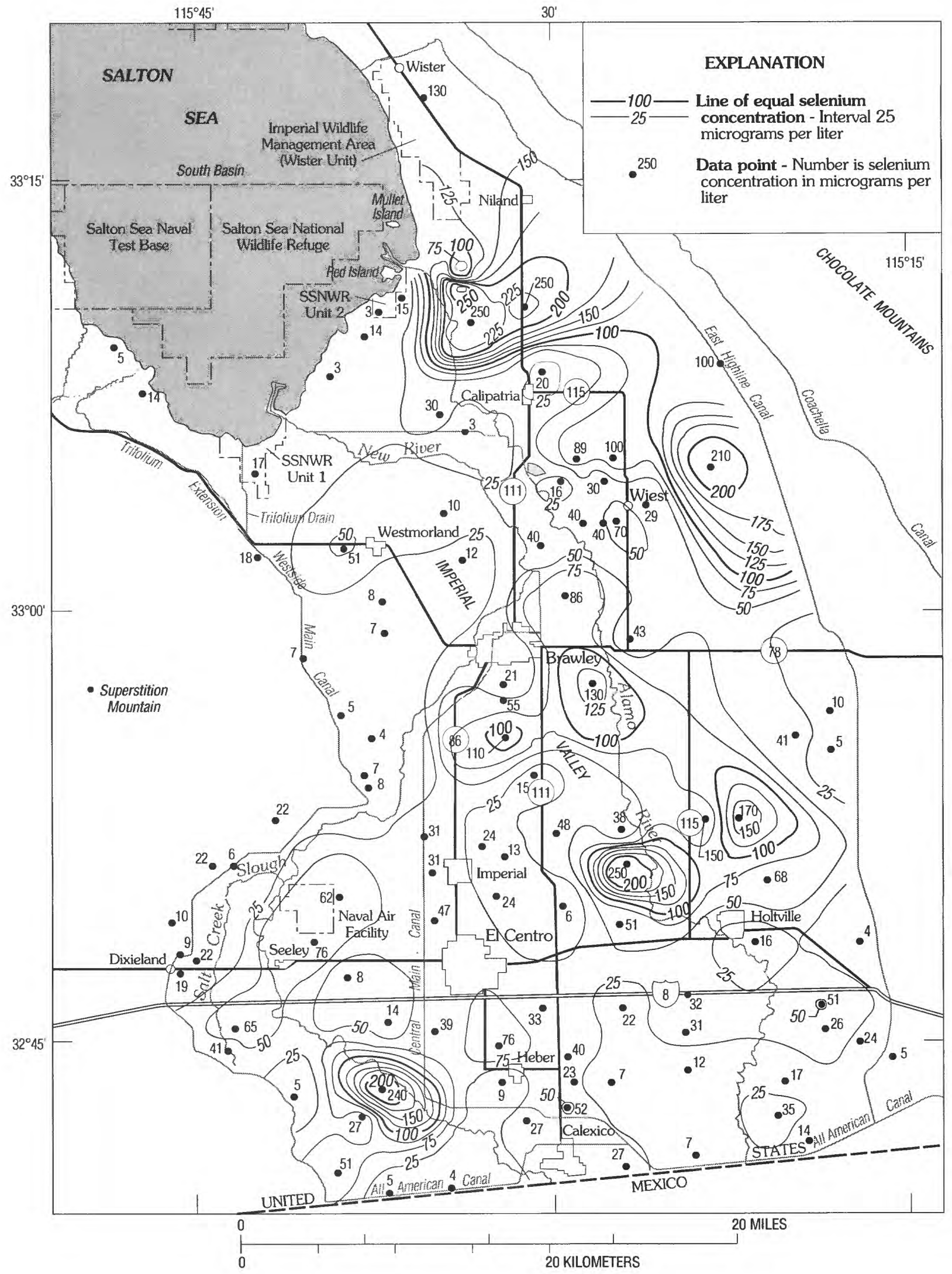

Figure 12. Areal distribution of selenium concentration in subsurface-drainwater samples collected in the Imperial Valley, May 1988. 


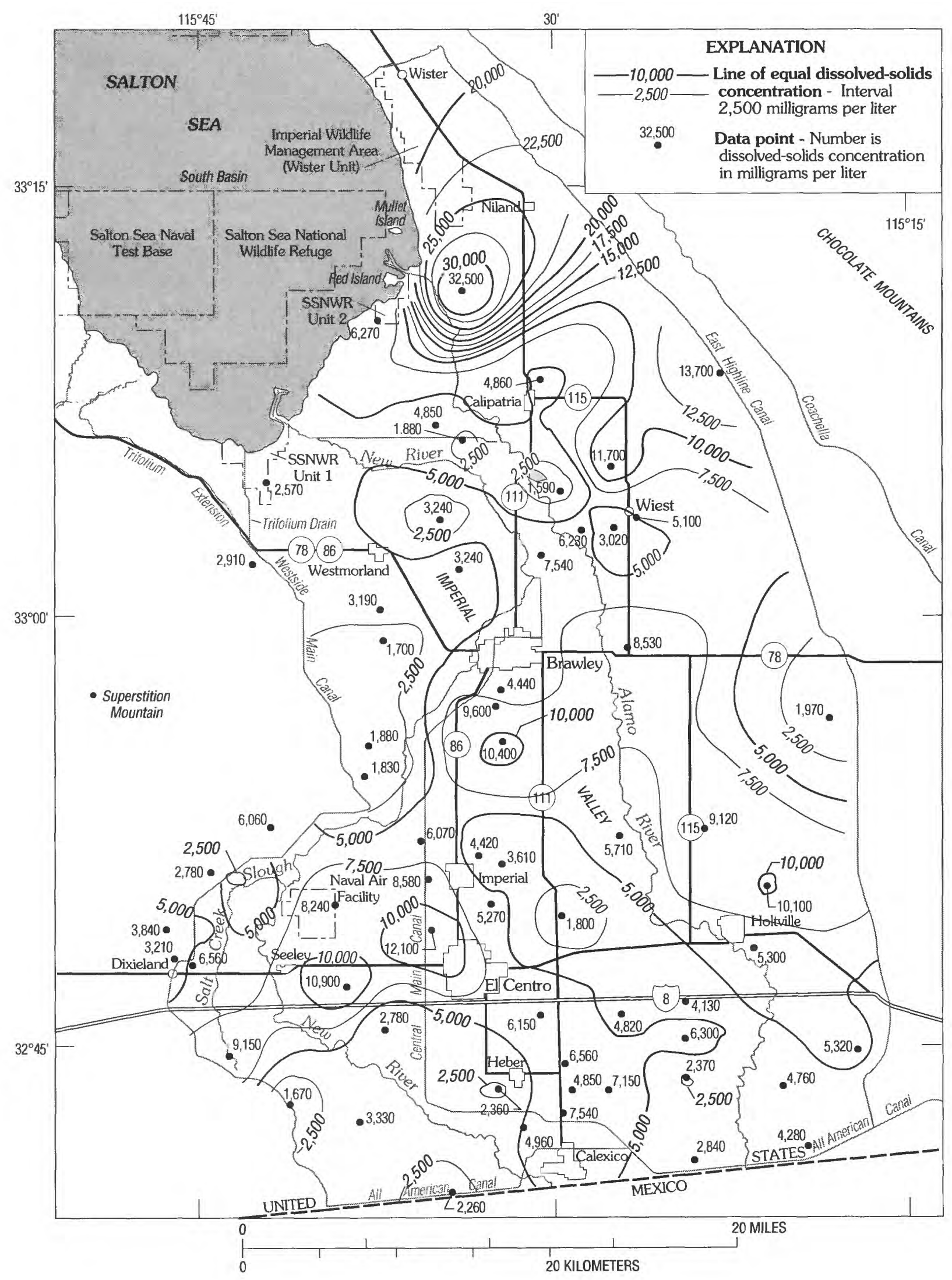

Figure 13. Areal distribution of dissolved-solids concentration in subsurface-drainwater samples collected in the Imperial Valley, May 1988. 


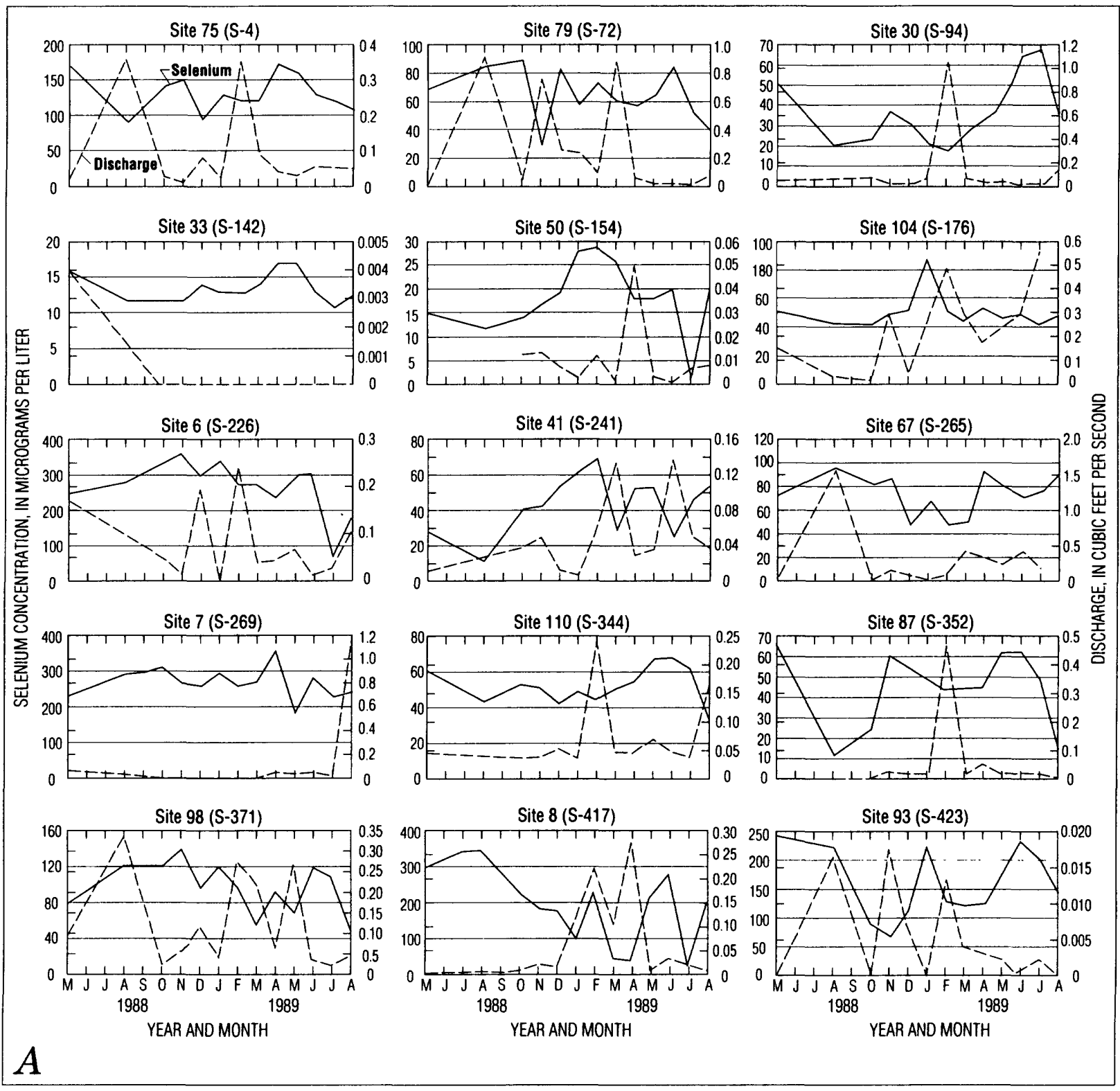

Figure 14. Temporal variation in instantaneous discharge and in concentrations of selected constituents in subsurface-drainwater samples collected from 15 fields in the Imperial Valley, May 1988 and August 1988-August 1989. A, Selenium concentration and discharge. B, Specific conductance. $C$, Selenium-to-chloride ratio. $D$, Dissolved-solids concentration. Site number, with sump number in parentheses, is given above each graph. Location of sites is shown in figure 9.

Comparison of May 1988 selenium concentrations at each of the 15 sites with the mean concentrations of the subsequent monthly samples indicates that the May samples are reasonably representative of the general water quality. The selenium data for the 15 sites, including standard deviation and selenium load, are summarized in table 6 . The load values are estimates for water year 1989 calculated by summation of the monthly instantaneous levels (selenium concentration times discharge); these estimates provide an indication of the quantity of selenium contributed during the period by each field. The data also show that the volume of flow from a sump is the main variable influencing selenium load. Whereas the range of selenium concentration in samples of subsurface drainwater was one order of magnitude, the range in volume of subsurface drainflow was three orders of magnitude. Overall, the highest loads occurred only during high discharges.

At most sites, selenium concentrations from the May 1988 sampling seem to be representative of the 


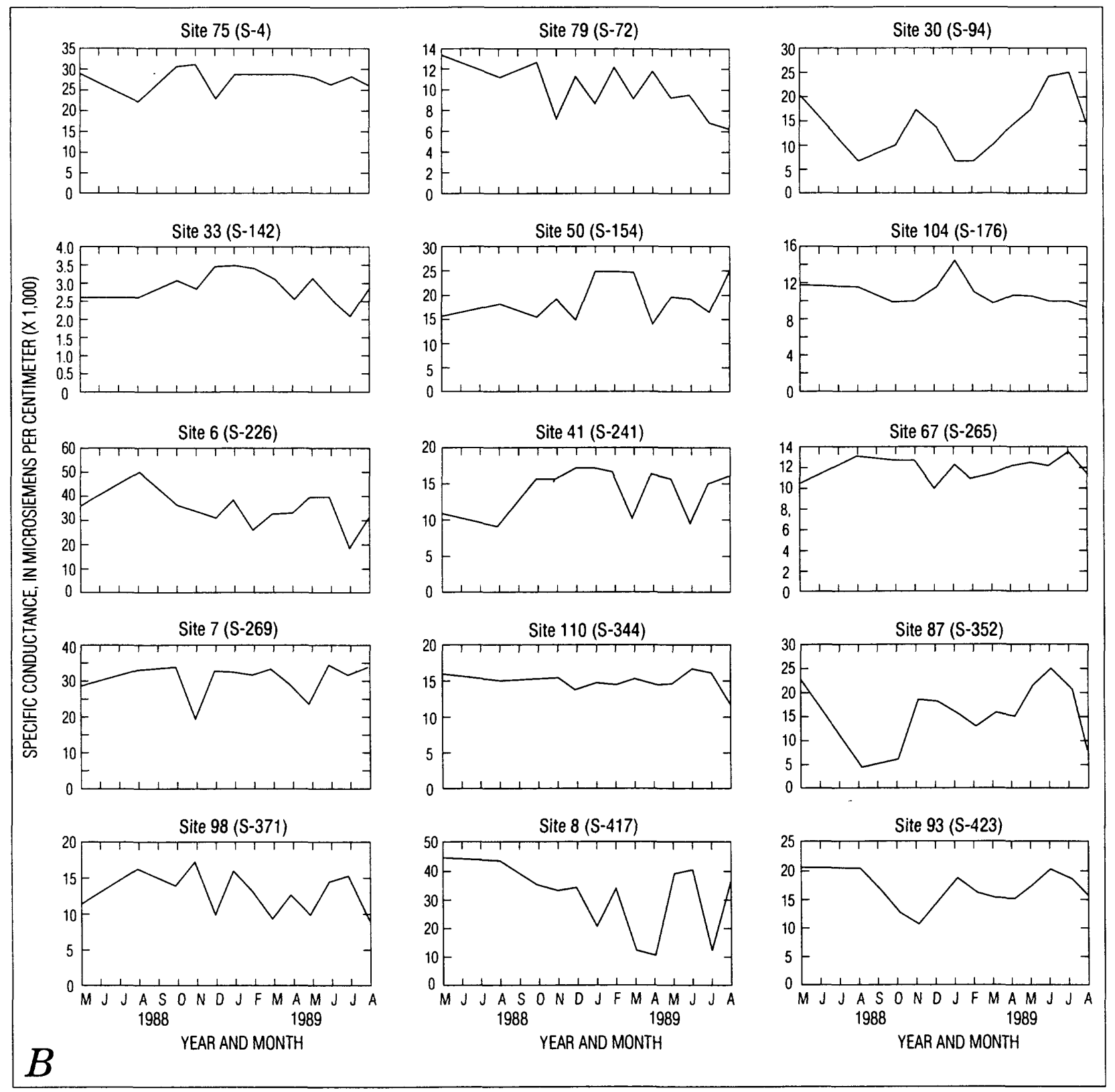

Figure 14. Continued.

mean monthly concentration. Although some sites had large differences between the May 1988 and mean monthly concentrations, the differences were not greater than expected from the normal monthly variations. At 11 of the 15 sites, the selenium concentration for the May sample fell within one standard deviation of the mean monthly concentration. At the four other sites $(93,8,3$, and 87$)$, the selenium concentration for the May sample fell just outside one standard deviation of the mean concentration. None, however, was sufficiently outside the range as to change the ranking of the site from one with low concentration to one with high concentration or, conversely, from high to low. $\mathrm{Se} / \mathrm{Cl}$ ratios that were calculated from the monthly samples are a further indication that the May 1988 samples are representative of irrigation drainage at the 15 sites; the ratios also show, by their small month-to-month differences, the covariance of selenium and chloride on common factors (solubility and dilution by recent irrigation). The mean $\mathrm{Se} / \mathrm{Cl}$ ratios for the monthly samples, as well as the values for the May 1988 sample, are given in table 6 . The $\mathrm{Se} / \mathrm{Cl}$ ratio for the May 1988 sample from site $33\left(7.3 \times 10^{-5}\right)$ differs the most from the mean $\left(4.7 \pm 1.2 \times 10^{-5}\right)$ of the monthly values. No discharge into the sump (S-142) at site 33 


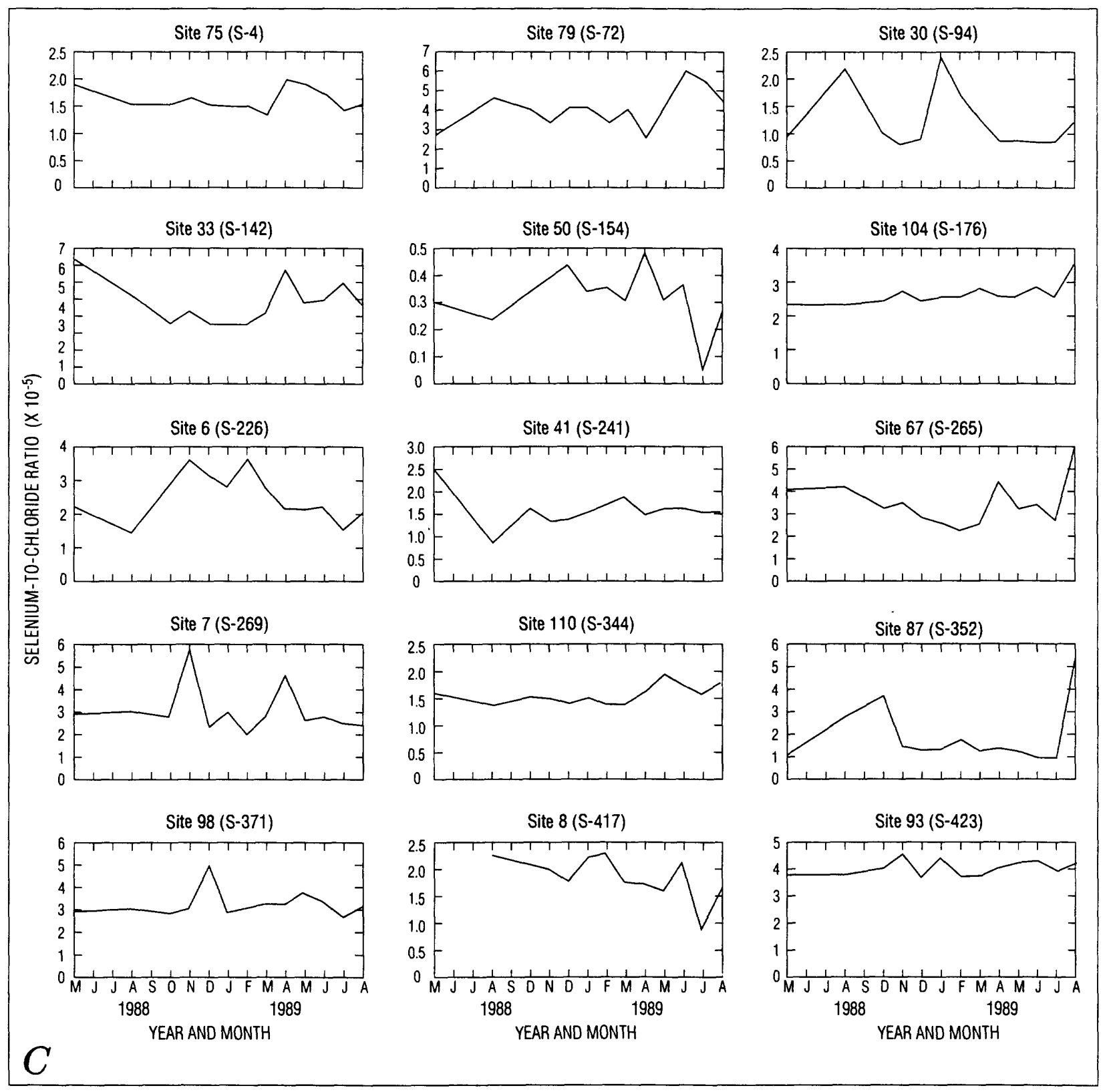

Figure 14. Continued.

was observed at any time during the year-long sampling period. Because no flow was observed, except during collection of the initial sample in May 1988 , this site is not typical of irrigated fields in the Imperial Valley.

Regression of monthly selenium against chloride concentrations was done to illustrate the codependence of these constituents on a common factor-their mutual dilution in base flow following recent application of irrigation water. Correlations were generally high and $\mathrm{Se} / \mathrm{Cl}$ ratios are nearly constant, indicating that selenium concentration varies directly with chloride concentration (table 6), The exceptions are site
33 (sump S-142), site 67 (sump S-265), and site 7 (sump S-269). The change in monthly concentrations at these sites is comparatively small and, therefore, may not provide a sensitive test for the correlation. Field observations and isotopic data also suggest that site 33 (sump S-142) has an anomalous pattern of usage. No flow to the sump was observed during monthly sample collections after May 1988, and the field was dry during the winter months. Hydrogenisotope ratios gradually increased from -99 permil on November 13,1988 , to -82 permil on March 15 , 1989 , along with a modest increase in dissolved solids. The dissolved-solids concentration at the end of this period, however, still was far less than would 


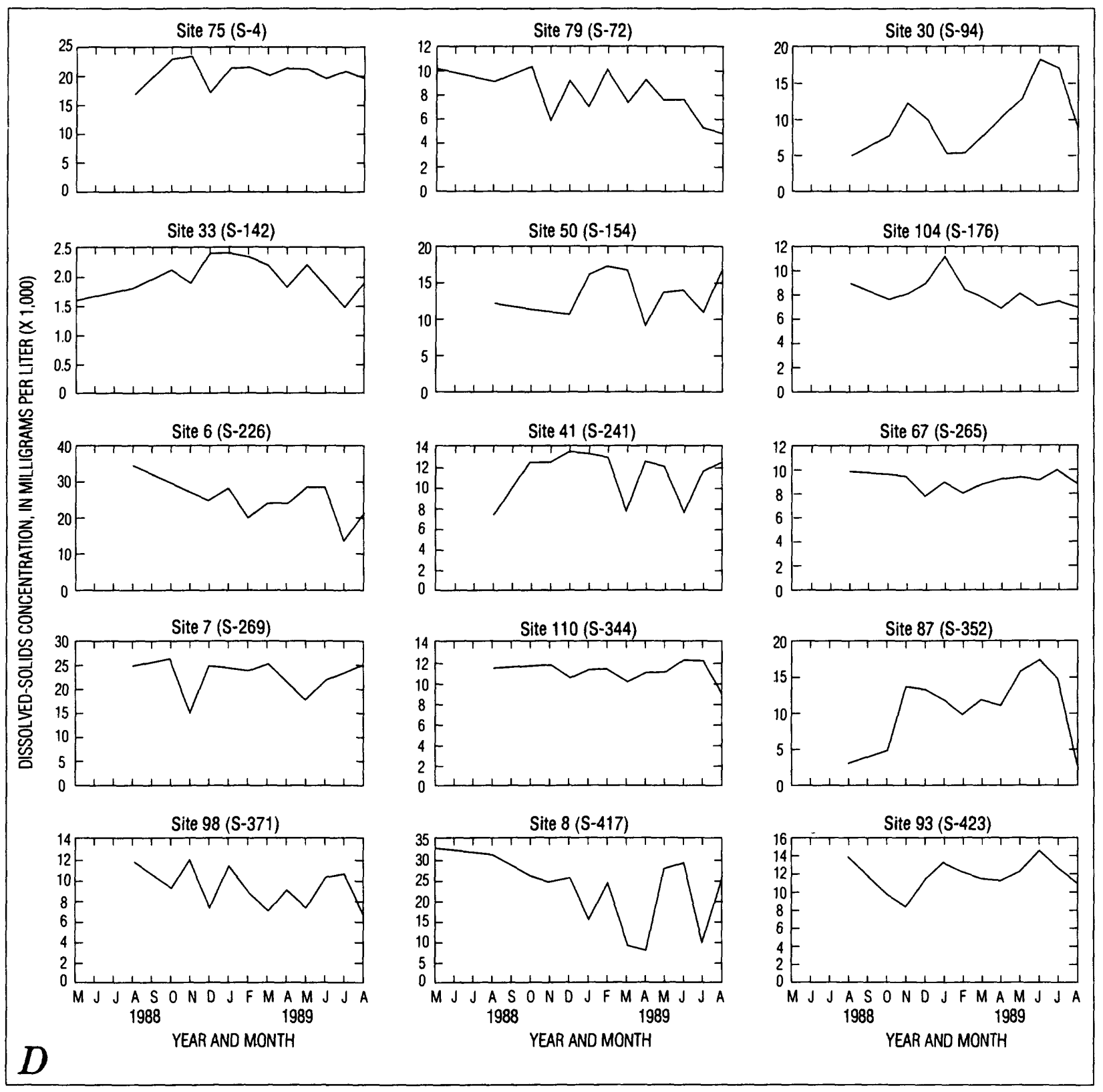

Figure 14. Continued.

be expected on the basis of the relation between isotope ratios and soluble ions at other sumps. Winter temperatures in this sump also were several degrees lower than in other sumps where flow was observed. It seems likely that this field, whose baseflow is zero, was not irrigated during the winter, and thus water remaining in the sump simply underwent evaporation during this period. Either irrigation resumed or rainfall occurred after March 15 as the April 10, 1989, sample had a hydrogen-isotope ratio of -97 permil and a decrease in dissolved salts.
A few of the sites with the highest average $\mathrm{Se} / \mathrm{Cl}$ ratios, or with occasional high ratios in the monthly samples, indicated a possible selenium source of comparable magnitude to the irrigation water in those fields. However, of greater significance and more frequent occurrence (on the basis of data from all 108 sumps) are those fields that seem to function as a sink for selenium. Site 50 (sump S-154), for which the $\mathrm{Se} / \mathrm{Cl}$ ratio was $0.33 \times 10^{-5}$, is a good example. The ratio at this site is an order-of-magnitude less than the ratio at the 14 other sites. The selenium load at this 
Table 6. Summary statistics for selected constituents in monthly samples of water from 15 subsurface drains in the Imperial Valley, August 1988-August 1989

[Location of sites shown in figure 9. Values for selenium concentration and selenium-to-chloride weight ratio are mean monthly values and (in italics) May 1988 values. Selenium load is estimate for water year $1989 . \mu \mathrm{g} / \mathrm{L}$, microgram per liter; lb, pound; < actual value is less than value shown]

\begin{tabular}{|c|c|c|c|c|c|c|}
\hline \multirow{2}{*}{$\begin{array}{l}\text { Site } \\
\text { No. }\end{array}$} & \multirow{2}{*}{$\begin{array}{l}\text { Local } \\
\text { identifier }\end{array}$} & \multicolumn{2}{|c|}{ Selenium concentration $(\mu \mathrm{g} / \mathrm{L})$} & \multicolumn{2}{|c|}{ Selenium/chloride ratio } & \multirow{2}{*}{$\begin{array}{l}\text { Selenium load } \\
\text { (lb) }\end{array}$} \\
\hline & & $\overline{\text { Value }}$ & $\overline{\text { Range }}$ & $\begin{array}{c}\text { Value } \\
\left(\times 10^{-5}\right)\end{array}$ & $\overline{r^{2} \text { value }}$ & \\
\hline 79 & S-72 & $\begin{array}{r}61 \pm 18.8 \\
68\end{array}$ & $28-88$ & $\begin{array}{r}4 \pm 1 \\
2.7\end{array}$ & 0.52 & 29 \\
\hline 98 & S-371 & $\begin{array}{r}94 \pm 30 \\
76\end{array}$ & $43-140$ & $\begin{array}{r}3.3 \pm 0.5 \\
2.9\end{array}$ & .87 & 22.3 \\
\hline 104 & S-176 & $\begin{array}{r}50 \pm 11.5 \\
51\end{array}$ & $41-86$ & $\begin{array}{r}2.7 \pm 0.4 \\
2.3\end{array}$ & .83 & 21.5 \\
\hline 50 & S-154 & $\begin{array}{r}19 \pm 6.7 \\
15\end{array}$ & $2-29$ & $\begin{array}{r}0.3 \pm 0.1 \\
0.33\end{array}$ & .51 & .4 \\
\hline 110 & S-344 & $\begin{array}{r}51 \pm 9.7 \\
60\end{array}$ & $36-68$ & $\begin{array}{r}1.6 \pm 0.2 \\
1.6\end{array}$ & .68 & 7.6 \\
\hline 93 & $S-423$ & $\begin{array}{r}158 \pm 56 \\
240\end{array}$ & $68-240$ & $\begin{array}{r}4 \pm 0.3 \\
3.8\end{array}$ & .96 & 1.3 \\
\hline 8 & $S-417$ & $\begin{array}{r}184 \pm 99 \\
300\end{array}$ & $19-340$ & $\begin{array}{r}1.9 \pm 0.4 \\
1.8\end{array}$ & .92 & 16.7 \\
\hline 33 & S-142 & $\begin{array}{r}13.5 \pm 2 \\
16\end{array}$ & $11-17$ & $\begin{array}{r}4.7 \pm 1.2 \\
7.3\end{array}$ & .019 & $\left({ }^{1}\right)$ \\
\hline 75 & $S-4$ & $\begin{array}{r}130 \pm 25 \\
170\end{array}$ & $91-170$ & $\begin{array}{r}1.6 \pm 0.2 \\
1.8\end{array}$ & .58 & 21.2 \\
\hline 67 & S-265 & $\begin{array}{r}78 \pm 17 \\
76\end{array}$ & $50-99$ & $\begin{array}{r}3.6 \pm 1.1 \\
4\end{array}$ & $<.01$ & 55 \\
\hline 87 & S-352 & $\begin{array}{r}42 \pm 19 \\
65\end{array}$ & $12-65$ & $\begin{array}{r}2 \pm 1.4 \\
1.1\end{array}$ & .90 & 4.2 \\
\hline 6 & $S-226$ & $\begin{array}{r}267 \pm 75 \\
250\end{array}$ & $71-360$ & $\begin{array}{r}2.5 \pm 0.7 \\
2.3\end{array}$ & .28 & 40.9 \\
\hline 7 & S-269 & $\begin{array}{r}267 \pm 44 \\
230\end{array}$ & $180-360$ & $\begin{array}{r}3 \pm 1 \\
2.9\end{array}$ & .03 & 54.6 \\
\hline 30 & S-94 & $\begin{array}{r}35 \pm 16 \\
51\end{array}$ & $17-67$ & $\begin{array}{r}1.1 \pm 0.6 \\
0.9\end{array}$ & .96 & 5.5 \\
\hline 41 & S-241 & $\begin{array}{r}45 \pm 16 \\
30\end{array}$ & $13-70$ & $\begin{array}{r}1.6 \pm 0.3 \\
2.5\end{array}$ & .88 & 4.2 \\
\hline
\end{tabular}

${ }^{1}$ No flow observed. 
Table 7. Summary statistics for selected constituents in monthly samples of water from six sites in the Imperial Valley, August 1988-August 1989

[Selenium load is estimate for water year 1989. $\mu \mathrm{g} / \mathrm{L}$, microgram per liter; $\mathrm{mg} / \mathrm{L}$, milligram per liter; --, not calculated]

\begin{tabular}{|c|c|c|c|c|c|c|}
\hline \multirow{2}{*}{ Site } & \multicolumn{3}{|c|}{ Selenium concentration $(\mu \mathrm{g} / \mathrm{L})$} & \multirow{2}{*}{$\begin{array}{l}\text { Selenium/ } \\
\text { chloride } \\
\text { ratio } \\
\left(\mathrm{x} 10^{-5}\right)\end{array}$} & \multirow{2}{*}{$\begin{array}{l}\text { Dissolved- } \\
\text { solids } \\
\text { concentration } \\
(\mathrm{mg} / \mathrm{L})\end{array}$} & \multirow{2}{*}{$\begin{array}{c}\text { Selenium } \\
\text { load } \\
\text { (tons) }\end{array}$} \\
\hline & $\overline{\text { Median }}$ & Minimum & Maximum & & & \\
\hline $\begin{array}{l}\text { Alamo River at international } \\
\text { boundary }\end{array}$ & $\begin{array}{r}4.5 \\
\pm 2.6\end{array}$ & 3 & 10 & $\begin{array}{l}0.42 \\
\pm .4\end{array}$ & $\begin{array}{l}3,690 \\
\pm 501\end{array}$ & $\begin{array}{l}-- \\
--\end{array}$ \\
\hline $\begin{array}{l}\text { Alamo River at outlet to } \\
\text { Salton Sea }\end{array}$ & $\begin{array}{r}8.0 \\
\pm 2.1\end{array}$ & 2 & 10 & $\begin{array}{l}1.7 \\
\pm .26\end{array}$ & $\begin{array}{r}2,170 \\
\pm 159\end{array}$ & 6.5 \\
\hline East Highline Canal & $\begin{array}{l}2.0 \\
\pm .3\end{array}$ & 2 & 3 & $\begin{array}{l}2.2 \\
\pm .35\end{array}$ & $\begin{array}{l}686 \\
\pm 41\end{array}$ & - \\
\hline $\begin{array}{l}\text { New River at international } \\
\text { boundary }\end{array}$ & $\begin{array}{l}2.0 \\
\pm .5\end{array}$ & $\begin{array}{l}1 \\
1\end{array}$ & $\begin{array}{l}2 \\
2\end{array}$ & $\begin{array}{r}.15 \\
\pm .06\end{array}$ & $\begin{array}{l}2,670 \\
\pm 362\end{array}$ & .5 \\
\hline $\begin{array}{l}\text { New River at outlet to } \\
\text { Salton Sea }\end{array}$ & $\begin{array}{l}4.0 \\
\pm .5\end{array}$ & 4 & 5 & $\begin{array}{r}.45 \\
\pm .06\end{array}$ & $\begin{array}{r}2,835 \\
\pm 130\end{array}$ & 2.5 \\
\hline Trifolium Drain 1 & $\begin{array}{l}6.0 \\
\pm 2\end{array}$ & 5 & 10 & $\begin{array}{r}1.2 \\
\pm 3.3\end{array}$ & $\begin{array}{r}2,350 \\
\pm 798\end{array}$ & - \\
\hline
\end{tabular}

site also was the lowest of the 15 sites, $0.4 \mathrm{lb}$. The field drained by this sump is in an old lakebed (Mesquite Lake), and the field reportedly is difficult to farm; as a result, irrigation has been applied repeatedly to leach the soil (B.S. Baharie, U.S. Geological Survey, oral commun., 1989). Chemical and isotopic analyses of water samples from lysimeters and wells at this site (see later section "Interaction of Subsurface Drainwater and Shallow Ground Water" and Schroeder and others, 1991, for full discussion) suggest that the removal of selenium is a result of microbial reduction and the upward intrusion of the selenium-depleted ground water to shallow depths.

Monthly water samples were collected at selected surface-water sites during August 1988 to August 1989 to determine the time-series variation in constituent concentrations. Coupled with water discharge, this information can be useful in providing an estimate of constituent loading to the Salton Sea. The median selenium concentration in the Alamo River at the outlet to the Salton Sea was $8 \mu \mathrm{g} / \mathrm{L}$ (table 7). This concentration at a volume of 600,500 acre-ft for water year 1989 gives a load of 6.5 tons of selenium. (Similar calculations for boron yield a load of 460 tons.) The New River at its outlet to the Salton Sea delivered 2.5 tons of selenium in water year 1989, 2.0 tons of which was contributed by irrigated agriculture in the Imperial Valley (estimates, using median selenium concentration at the international boundary and at the outlet to the Salton Sea). Salt loading to the sea also is substantial. The combined load of the New and Alamo Rivers is 3.6 million tons of salt for water year 1989. This load, coupled with an evaporation rate of $5.8 \mathrm{ft} / \mathrm{yr}$ in the Salton Sea (Hely and others, 1966), results in increasing salinity levels in the Salton Sea.

Selenium concentration in the Alamo River at the outlet to the Salton Sea is fairly constant. The standard deviation of $2.1 \mu \mathrm{g} / \mathrm{L}$ includes results from an April 1989 sample in which total selenium concentration was only $2 \mu \mathrm{g} / \mathrm{L}$ (a probable outlier). A concurrent sample for dissolved selenium had a concentration of $8 \mu \mathrm{g} / \mathrm{L}$. Flow in the Alamo River, effectively, is an average of the irrigation drainage from the Imperial Valley and varies with the seasonal pattern of irrigation and with infrequent storms (fig. 15). Water quality in the New River at its outlet to the Salton Sea is additionally influenced by the quality of water crossing the international boundary at Calexico, where the median selenium concentration was $2 \mu \mathrm{g} / \mathrm{L}$. Water crossing the international boundary constitutes about 40 percent of the total flow in the New River at its outlet to the Salton Sea. As a 


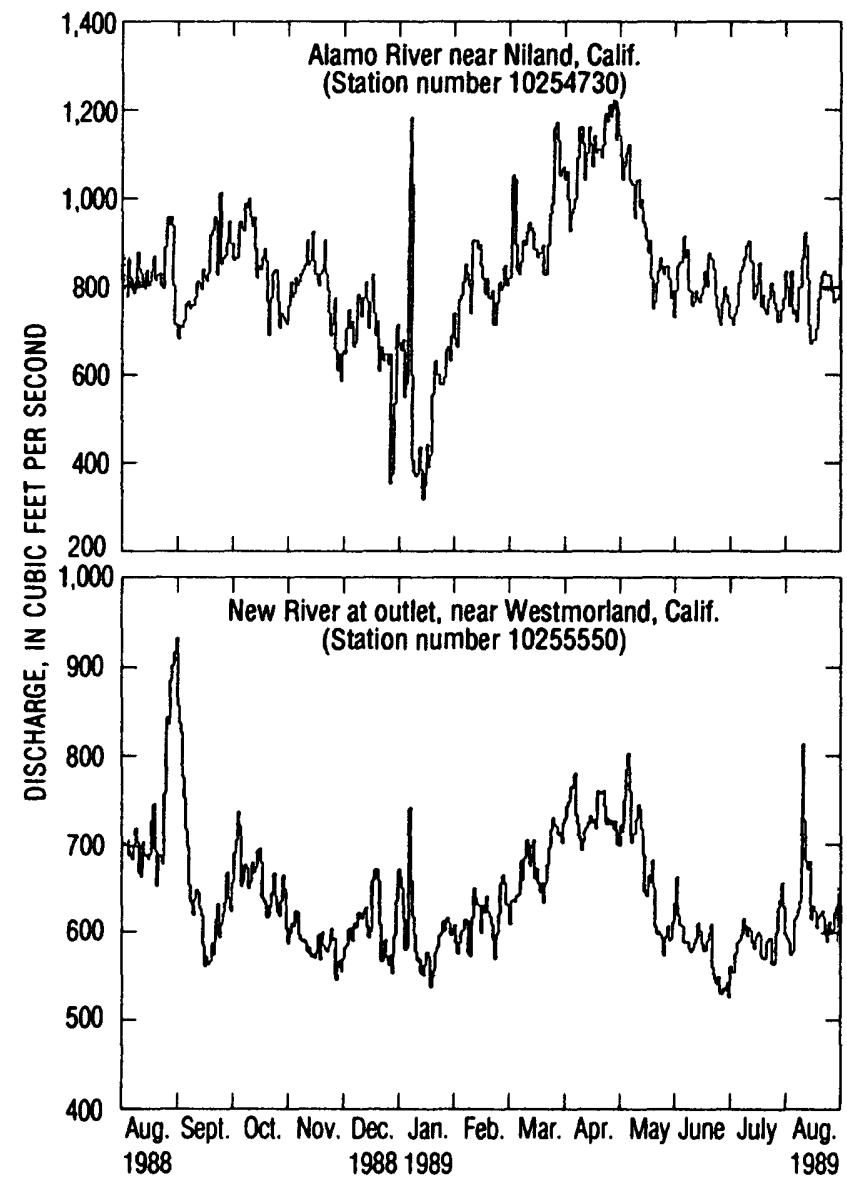

Figure 15. Daily mean discharge in the Alamo River near Niland and the New River at outlet, near Westmorland, August 1988-August 1989.

result of dilution by low-selenium water crossing the international boundary, selenium concentrations in the outflowing water from the New River are about 50 percent lower than in water from the Alamo River. The Colorado River water (in the East Highline Canal) that is used for irrigated agriculture in the Imperial Valley also is very constant in composition, as shown by a selenium concentration (for monthly samples collected during the 1989 water year) of $2 \pm$ $0.3 \mu \mathrm{g} / \mathrm{L}$.

Element ratios in monthly water samples collected from the major rivers also were examined to determine the presence of sources or sinks of selected constituents within the agricultural system of the Imperial Valley. During the analysis of subsurface drainwater, $\mathrm{Se} / \mathrm{Cl}$ ratios were evaluated to determine sources and (or) sinks of selenium. These ratios also can be used in the rivers to determine losses or gains of selenium. Water in the East Highline Canal had a median $\mathrm{Se} / \mathrm{Cl}$ ratio of $2.2 \times 10^{-5}$ (table 7). Representing the cumulative mixing of subsurface drain- water and tailwater, the Alamo River is the best available indicator of the effects of irrigated agriculture on water quality in the Imperial Valley. The median $\mathrm{Se} / \mathrm{Cl}$ ratio in the Alamo River at the outlet to the Salton Sea was $1.7 \times 10^{-5}$. These two statistically different ratios (Kruskal-Wallis Test Statistic $=14.026$; chi-square distribution value is $3.84, \alpha<0.05$ ) indicate a small loss (about 20 percent) of selenium in comparison with chloride. Selenium in most of the Imperial Valley, as indicated by the $\mathrm{Se} / \mathrm{Cl}$ ratio of input to output water, generally behaves conservatively as it is transported to the Salton Sea, and there are no major sources or sinks as selenium moves from application with the irrigation water to discharge from the Alamo River.

Even a generalized comparison shows that both selenium and dissolved solids increase by a factor of about four from the East Highline Canal to the Alamo River at the outlet to the Salton Sea ( 2 to $8 \mu \mathrm{g} / \mathrm{L}$ and 686 to $2,170 \mathrm{mg} / \mathrm{L}$, respectively). The New River does not present a valid case for similar examination because 40 percent of the flow at the outlet to the Salton Sea originates in Mexico and is composed of domestic and municipal effluent. For Trifolium Drain 1 , the $\mathrm{Se} / \mathrm{Cl}$ ratio is $1.2 \times 10^{-5}$. This ratio indicates that some loss (or sink) of selenium is occurring relative to chloride. Trifolium Drain 1 is located in the irrigated northwestern part of the Imperial Valley, west of the New River. Some fields in this area may be affected by conditions that are more reducing in this part of the valley. Mixing of water from these fields with water unaffected by reducing conditions might account for the lower $\mathrm{Se} / \mathrm{Cl}$ ratio in Trifolium Drain 1. Water in this drain discharges directly to the Salton Sea about 2 mi southwest of the New River delta.

A comparison of $\mathrm{Se} / \mathrm{Cl}$ ratios for input and output water indicate that little selenium is lost within the agricultural system of the Imperial Valley as a whole. Apparently, however, a considerable dilution of subsurface drainwater occurs between discharge from the sumps to the ditches and the outlet to the Salton Sea. Assuming that the May 1988 subsurface drainwater sampling of more than 100 sumps throughout the Imperial Valley is representative, the dischargeweighted selenium concentration is $25 \mu \mathrm{g} / \mathrm{L}$, which is the same as the median selenium concentration. The $\mathrm{Se} / \mathrm{Cl}$ ratio for the sites is $2 \times 10^{-5} \pm 1.5 \times 10^{-5}$, which is virtually identical to the ratio in the irrigation supply, and which indicates that little to no gain or loss in selenium has occurred. In order to reach a final selenium concentration of $8 \mu \mathrm{g} / \mathrm{L}$ in the Alamo River at the outlet to the Salton Sea, 
considerable dilution must occur. If the composition of the diluting water (surface runoff, including tailwater, and possibly seepage from unlined canals) is assumed to be the same as that of irrigation water, then the equation for a simple mixing model can be used to calculate the surface runoff $(x)$ to drainwater (1-x) proportion required to produce the observed dilution in the Alamo River as follows:

$$
x(2)+(1-x)(25)=8 \text {. }
$$

The fraction (x) is 74 percent, and thus the volume of surface runoff exceeds the volume of drainwater by a factor of 3 .

Boron can be examined in a manner similar to that employed for selenium. Boron concentration in the Alamo River at the outlet to the Salton Sea was $560 \mu \mathrm{g} / \mathrm{L}$. Substituting the boron values into the dilution equation (Colorado River water $=135 \mu \mathrm{g} / \mathrm{L}$ and subsurface drainwater $=1,800 \mu \mathrm{g} / \mathrm{L}$ ) yields exactly the same result (74 percent) obtained for selenium. Comparison of $\mathrm{B} / \mathrm{Cl}$ ratios as water moves through the hydrologic cycle $\left(1.54 \times 10^{-3}\right.$ in the East Highline Canal, $0.78 \times 10^{-3}$ in subsurface drainwater, $1.12 \times 10^{-3}$ in the Alamo River, and $0.78 \times 10^{-3}$ in the Salton Sea) indicates that there may be some removal of boron within the fields, possibly as an insoluble salt that is flushed from the fields with surface runoff. Such a scenario would be consistent with the fact that boron is less conservative than chloride. The pattern of $\mathrm{B} / \mathrm{Cl}$ ratios also shows that unlike selenium, which is removed from the water of the Salton Sea, boron continues to be concentrated by evaporation, and its concentration now is $11,000 \mu \mathrm{g} / \mathrm{L}$.

\section{PROCESSES CONTROLLING THE CONCENTRATION OF SELENIUM AND OTHER CONSTITUENTS}

\section{SUBSURFACE DRAINWATER}

\section{PHYSICAL CHARACTERISTICS OF FIELDS}

Among the many variables that affect concentrations of selenium and other constituents in subsurface drainwater, the physical characteristics-especially of soils - of individual fields are of particular significance. The physical layout of the field (including the spacing of subsurface drains), piezometric surfaces, and transit time of water in the field all are variables controlled by soil characteristics.

The irrigation cycle in the Imperial Valley begins as water requested by the farmers is delivered to the

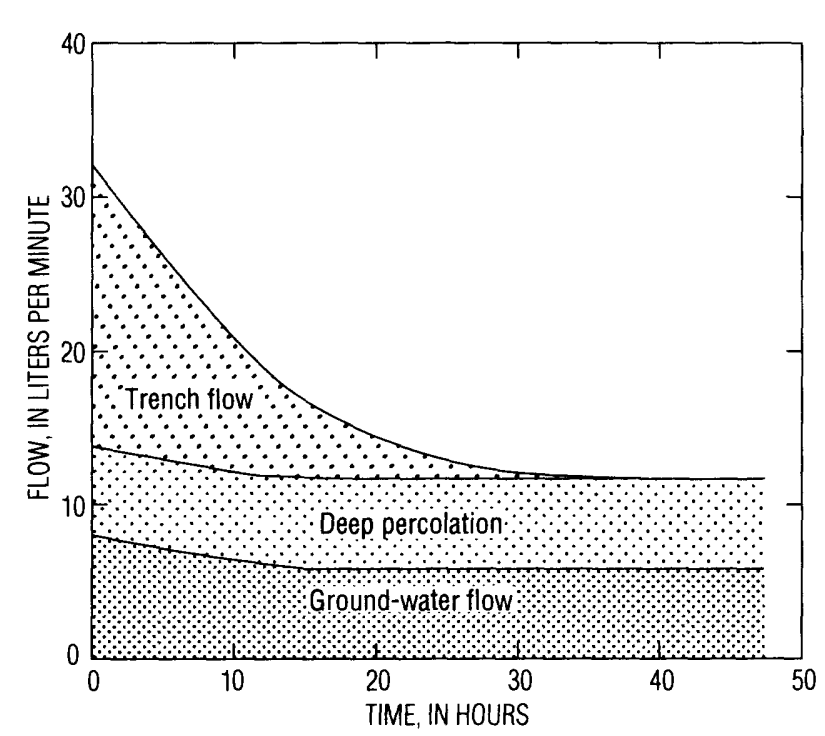

Figure 16. Contribution of trench flow to subsurface drainflow (from Tod and Grismer, 1988).

fields by a 1,675-mile network of canals operated by IID. Most fields use flood (furrow and border-strip) irrigation in which water applied to the head of the field flows downslope to the drainage ditch and sump at the tail, or lower end, of the field. Most fields in the Imperial Valley have gentle slopes of less than 0.2 percent. For clayey soils, such as those in the Imperial Formation, irrigation-run lengths of as much as $0.5 \mathrm{mi}$ are effective. For more sandy soils, such as the Rositas, shorter irrigation-run lengths of $300 \mathrm{ft}$ or less are desirable (Zimmerman, 1981, p. 39). Soil characteristics affect both the rate and path of water movement in the fields, and thus determine the spacing of subsurface drains (Hwang and others, 1974, p. 273).

The transit time of the water within a field and the water levels before, during, and after irrigation will vary according to soil type. In clayey areas, water applied to the surface flows through cracks in the soil and through backfilled soil in trenches dug during installation of subsurface drains. Soil excavated and backfilled into trenches dug to install subsurface drains has a higher permeability than adjacent undisturbed soils. Because of this increased permeability, most of the applied water flows through the trench backfill directly to the drains. Recent studies by Tod and Grismer (1988) at the University of California Field Station near Meloland (east of El Centro) indicate that subsurface drain flow in clayey soils returns to base-flow conditions within about 30 hours after irrigation. The contribution of trench flow to subsurface drainflow in a drain from their experimental field is shown in figure 16. The short dura- 
tion of increased discharge occurs because of rapid flow through the trench backfill.

Irrigation applied to the field is accounted for in the following manner. Tailwater is runoff that flows directly from the surface of the field to the drainage ditch. This flow occurs when either too much water is applied or earthen dikes retaining water at the tail of a field break. This flow is important to the dilution of subsurface drainwater and will be discussed later. Water also is lost by evapotranspiration. According to Zimmerman (1981), "Evapotranspiration from growing crops can easily exceed $6 \mathrm{ft}$ of water per year in this area. In the hot months in summer it may exceed $1 / 3$ in. of water per day." Of the water percolating through the soil, subsurface drains (at a depth of about $6 \mathrm{ft}$ ) affect only water that is within about $9 \mathrm{ft}$ (horizontal distance) of the drain (Tod and Grismer, 1988, p. 7). Water at greater distances is unaffected and moves as recharge to the aquifer beneath the field (fig. 17). Direct measurements indicated that water near (within $9 \mathrm{ft}$ of) the drains is in a null zone, neither moving rapidly toward the drain, nor toward the aquifer as quickly as water farther away (Tod and Grismer, 1988). The median tritium concentration in pore water collected at a depth of $3 \mathrm{ft}$ near drains in six fields was $32 \mathrm{TU}$, slightly higher than the tritium concentration in recently applied Colorado River water. Tritium concentrations of samples from a depth of $6 \mathrm{ft}$ near the drains have a median concentration of $52 \mathrm{TU}$, indicating water with a transit time of about 5 years.

For the 15 fields sampled during 1989, the soil type ranged from Imperial Formation clays in the northern part of Imperial Valley to the Rositas sands on the east and west sides of the valley to the south. The Imperial Formation soils are nearly level, moderately well drained silty clay in the lacustrine basin. These soils require good management practices and tile drains to maintain favorable salt balance and to keep the water table below the root zone (Zimmerman, 1981, p. 5). The Rositas soils are "nearly level to moderately steep, somewhat excessively drained sand, fine sand, and silt loam in alluvial basins and on fans and sandhills" (Zimmerman, 1981, p. 7). The spacing of subsurface drains is based on the soil type, and ranged from 50 $\mathrm{ft}$ in the northern part of Imperial Valley where silty clay soils are present to $400 \mathrm{ft}$ where sandy soils are present (Imperial Irrigation District, written commun., undated).

\section{EVAPORATIVE CONCENTRATION}

Hydrogen and oxygen isotopes and tritium concentrations were determined in water samples collected from sumps throughout the Imperial Valley to determine the source of water and the processes that have affected subsurface drainwater. Hydrogen and oxygen isotopes, which are chemically conservative, provide the ability to distinguish between an increase in dissolved-solids concentration owing to leaching without evaporation and an increase in dissolved solids owing to evaporation (Fontes, 1980, p. 121-122). Other indicators such as elemental ratios also can be used, but the interpretation of such indicators can be complicated in concentrated water by solubility-product considerations. Evaporation in an arid environment such as the Imperial Valley results in enrichment of the heavier isotope in the water that remains. For hydrogen and oxygen, this means that deuterium (D) $\left[{ }^{2} \mathrm{H}\right]$ and oxygen-18 $\left({ }^{18} \mathrm{O}\right)$ are enriched in relation to $\mathrm{H}\left[{ }^{1} \mathrm{H}\right]$ and ${ }^{16} \mathrm{O}$. The isotope concentrations are reported as $\delta \mathrm{D}$ and $\delta^{18} \mathrm{O}$, in permil, where

$$
\delta \mathrm{D}=\frac{\mathrm{D} / \mathrm{H} \text { sample }}{\mathrm{D} / \mathrm{H} \text { standard }-1} \times 1,000
$$

and

$$
\delta^{18} \mathrm{O}=\frac{\left({ }^{18} \mathrm{O} /{ }^{16} \mathrm{O}\right) \text { sample }}{\left({ }^{18} \mathrm{O} /{ }^{16} \mathrm{O}\right) \text { standard }-1} \times 1,000 .
$$

The standard for comparison is Vienna Standard Mean Ocean Water (V-SMOW).

For drainwater in the Imperial Valley it was found that $\delta \mathrm{D}=5.4 \delta^{18} \mathrm{O}-34$. The standard error of the slope is 0.16 (Schroeder and others, 1991). In a study of irrigation drainage wells in the Juarez Valley of Mexico, Fontes (1980, p. 122) found that $\delta D=5.8$ $\delta^{18} \mathrm{O}-21$. A slope of 5.8 for the regression model is indicative of evaporative concentration and the increase in salinity (dissolved solids) is due to evaporation (Craig, 1966, p. 1544; Fontes, 1980, p. 122). The regression lines of the plots from the two studies have similar slopes, 5.8 and 5.4. These results indicate that the range in dissolved-solids concentration observed for subsurface drainwater in the Imperial Valley is consistent with evaporative concentration. The regression of hydrogen and oxygen isotopes along with Craig's global meteoric water line is shown in figure 18. Of particular significance is that the $r^{2}$ for the regression is $0.96, \alpha<0.01$, indicating that subsurface drainwater in sumps throughout the Imperial Valley have a single source of water. Colorado River water in the East Highline Canal used for irrigation in the Imperial Valley has a $\delta \mathrm{D}$ of about -103 and a $\delta^{18} \mathrm{O}$ of about -13 . These values plot on the lower end of the regression line shown in figure 18, as would be expected if the 

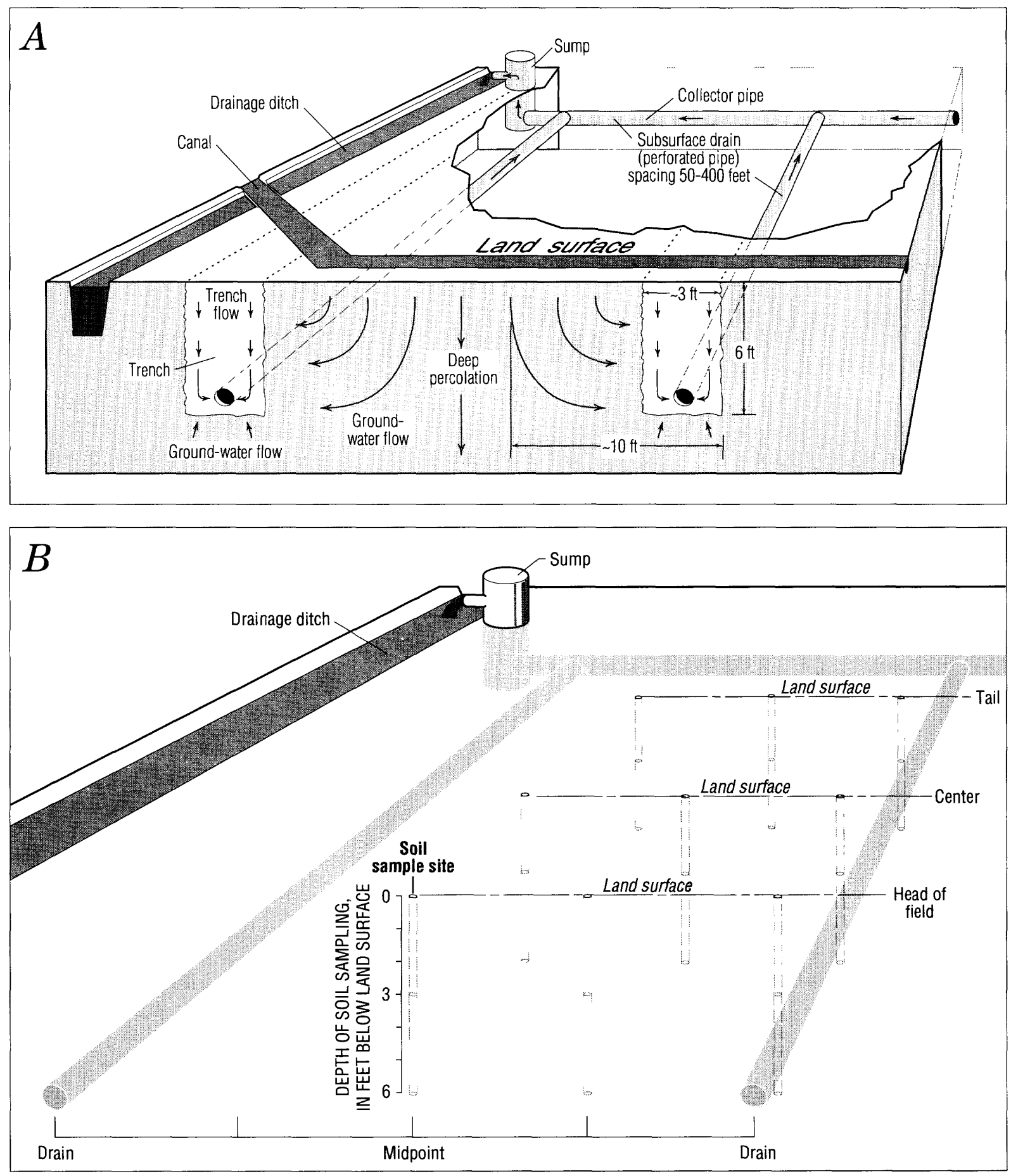

Figure 17. Movement of water and layout of subsurface drains (A), and configuration of soilsampling sites (B), in a typical field in the Imperial Valley.

Colorado River is the source of subsurface drainwater. The line showing the relation between hydrogen and oxygen isotopes in drainwater, when extrapolated in the other direction, passes through the isotopic composition of the water of the Salton Sea as well. This extrapolation shows that water in the Salton Sea, which is the terminus of subsurface drainwater in the Imperial Valley, also is the product of evaporative concentration of Colorado River water (Craig, 1966, p. 1544). 


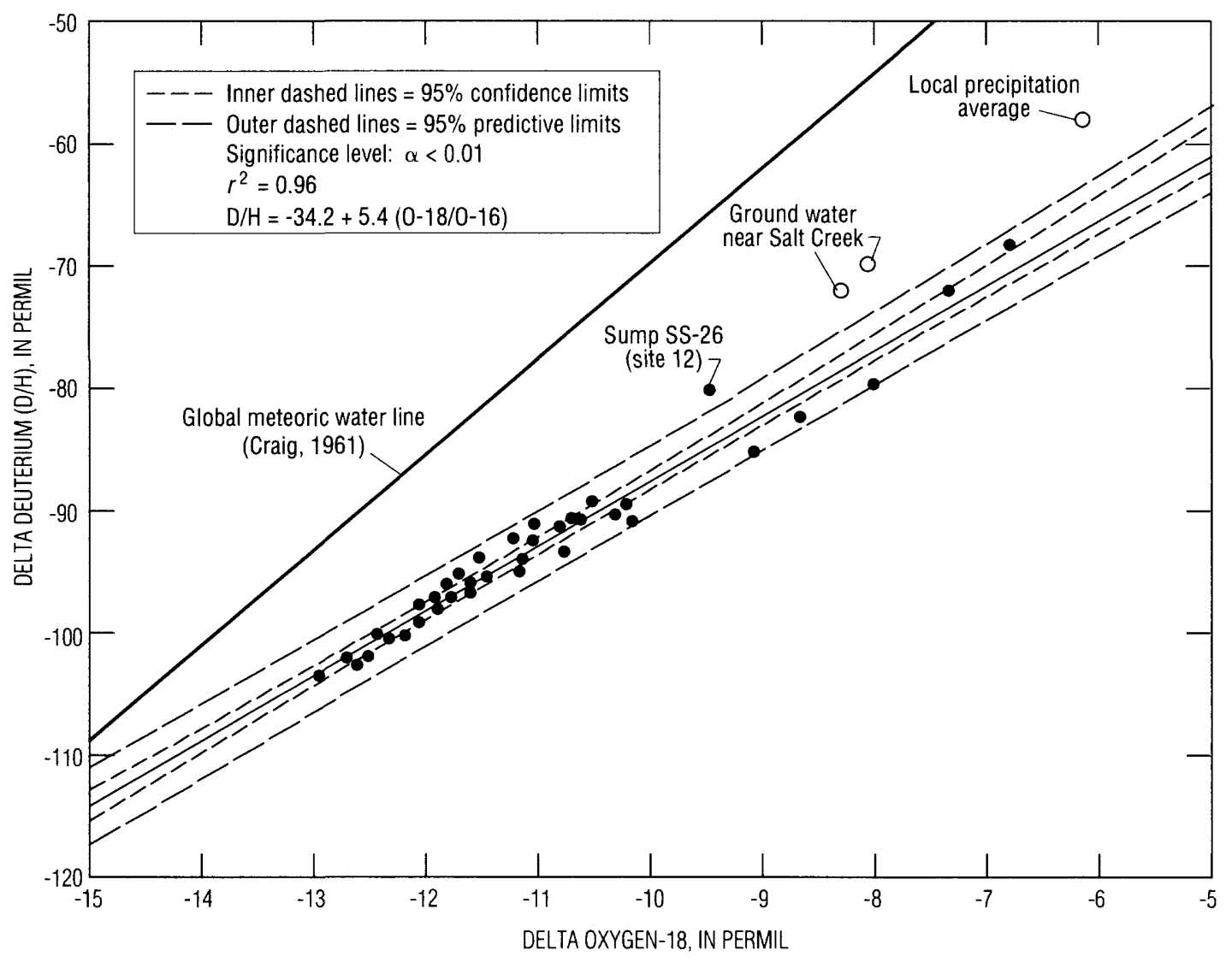

Figure 18. Regression plot of hydrogen- and oxygen-isotope ratios and global meteoric water line for subsurface-drainwater samples collected in the Imperial Valley, May 1988.

Although the regression of hydrogen and oxygen isotopes described above has an $r^{2}$ of 0.96 , there are a few points that clearly do not lie near the regression line. Water from San Felipe Creek (fig. 10A), which flows from the Santa Rosa Mountains to the Salton Sea on its southwestern side, had $\delta D$ and $\delta^{18} O$ values of -58 and -6 permil, respectively. These values plot to the left of the regression line and are indicative of water from local precipitation. The sump (SS-26) at site 12 (fig. 9) drains a field adjacent to the Salton Sea between San Felipe Creek and San Felipe Wash. Water from this site also plots to the left of the regression line at $\delta \mathrm{D}=-80$ permil and $\delta^{18} \mathrm{O}=-9.45$ permil, possibly indicating a mixture of evaporated Colorado River water and water from local precipitation. Water from two springs northeast of the Salton Sea near the Coachella Canal and Salt Creek also plots to the left of the regression line (Schroeder and others, 1991) and likely represents ground-water flow from the Chocolate Mountains that is derived from local precipitation (Craig, 1966).

\section{SELENIUM}

The isotope data indicate that evaporative concentration of irrigation water produces the range in dissolved-solids concentration observed in subsurface drainwater. The hypothesis for this study was that selenium detected in this drainwater also results from evaporative concentration of Colorado River water. For comparison, it has been found in other areas such as the San Joaquin Valley that high concentrations of selenium result from oxidation of reduced selenium minerals in the Coast Ranges or in soils derived from the Coast Ranges and from evaporative concentration (Deverel and Fujii, 1987). Data from 270 cores collected from 15 fields during this study of the Imperial Valley indicate that the soil is not a major source of selenium in irrigation drainwater.

Several methods of determining the cause of high selenium concentrations in subsurface drainwater are examined. Regression of $\delta \mathrm{D}$ against selenium concentration using data from all sites had an $r^{2}$ of 0.025 , 


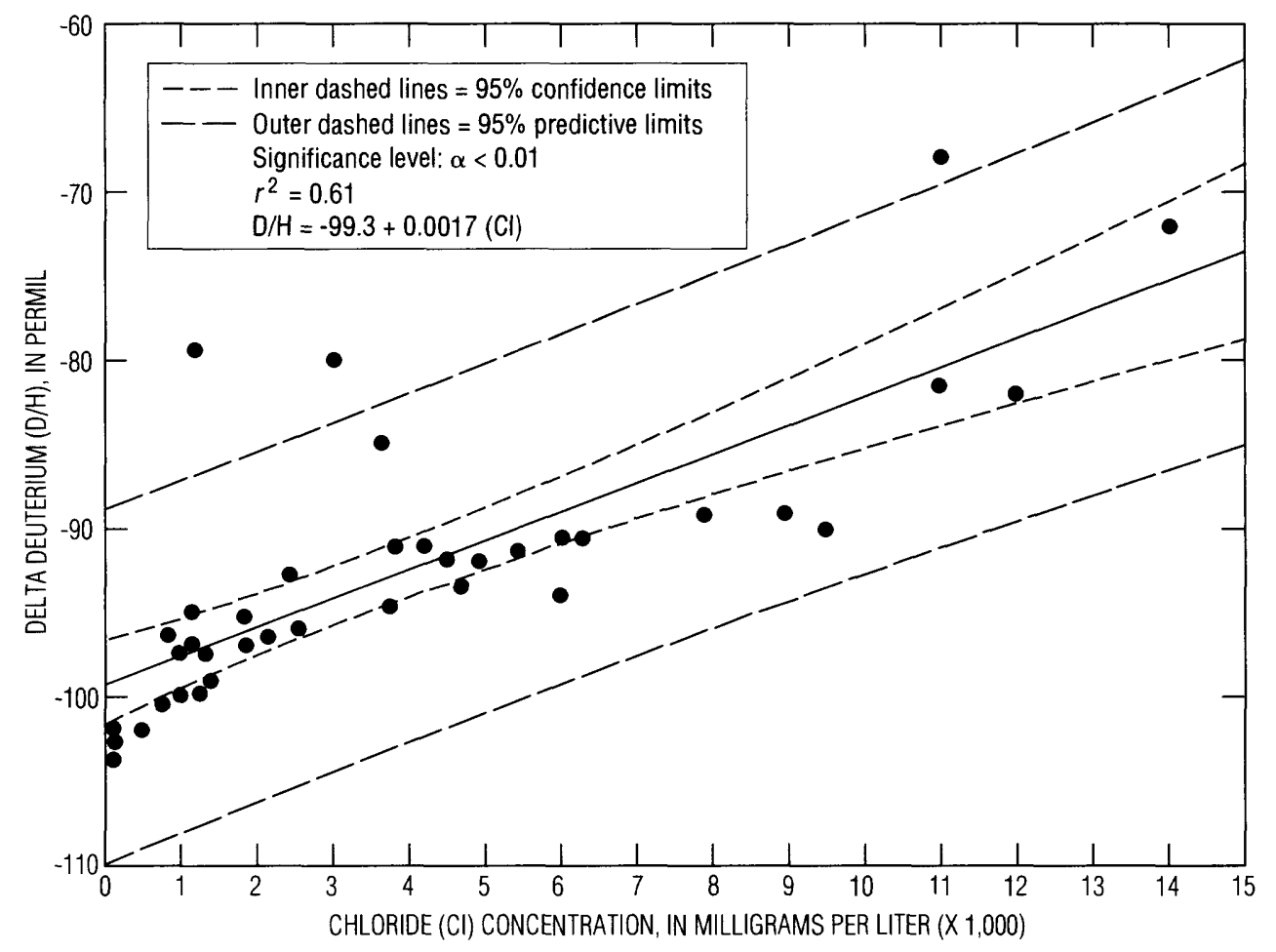

Figure 19. Regression plot of hydrogen-isotope ratio and chloride concentration for subsurface-drainwater samples collected in the Imperial Valley, May 1988.

$\alpha=0.33$. The regression plot is strongly affected by six sites $(4,9,12,14,15$, and 16$)$, which are sumps that drain fields in a narrow band along the southern end of the Salton Sea. These fields are affected by high chloride and low selenium concentrations from the Salton Sea and (or) reducing conditions. These conditions are highly atypical of most parts of the Imperial Valley, and when those sites are deleted from the regression, the $r^{2}$ becomes 0.62 . This high correlation between $\delta \mathrm{D}$ and selenium indicates that selenium concentrations in subsurface drainwater result from evaporative concentration of Colorado River water.

Similarly high correlations also result from regressions between $\delta \mathrm{D}$ and chloride concentration and between $\delta \mathrm{D}$ and dissolved-solids concentration, as would be expected for evaporative concentration.

The regression of $\delta \mathrm{D}$ against chloride concentration (fig. 19) has an $r^{2}$ (rounded) of $0.61, \alpha<0.01$. The correlation is increased when data from site 12 , believed to be affected by local precipitation as discussed earlier, is removed from the regression calculation.

Regression of selenium against chloride yields an $r^{2}$ of 0.33 . The $r^{2}$ value increases to 0.71 if only three sites $(4,14$, and 15) adjacent to the Salton Sea (refer to discussion of deuterium and selenium above) are removed from the regression (fig. 20). The high correlation demonstrates that the concentration of selenium in subsurface drainwater is controlled by evaporation of Colorado River water in a manner similar to that of chloride.

Elemental mass (weight) ratios provide a means to evaluate water-quality changes that occur in irrigation water as it moves through the agricultural system. Selenium can be compared with a variety of cations and anions to demonstrate compositional changes in water quality or to show sources or sinks of selenium. Chloride is chosen for comparison because it is chemically conservative and highly soluble. Colorado River water in the East Highline Canal had a selenium concentration of about $2 \mu \mathrm{g} / \mathrm{L}$ and a chloride concentration of about $100 \mathrm{mg} / \mathrm{L}$, giving a Se/Cl ratio of about $2 \times 10^{-5}$ for irrigation water in the Imperial Valley. Changes in the ratio occur if solubility affects one or the other ion, oxidation-reduction reactions take place, and (or) biological reactions selectively utilize one element or the other. In the Imperial Valley, it seems that selenium and chloride cycle through the agricultural system in an identical manner-precipitating and dissolving alike and being 


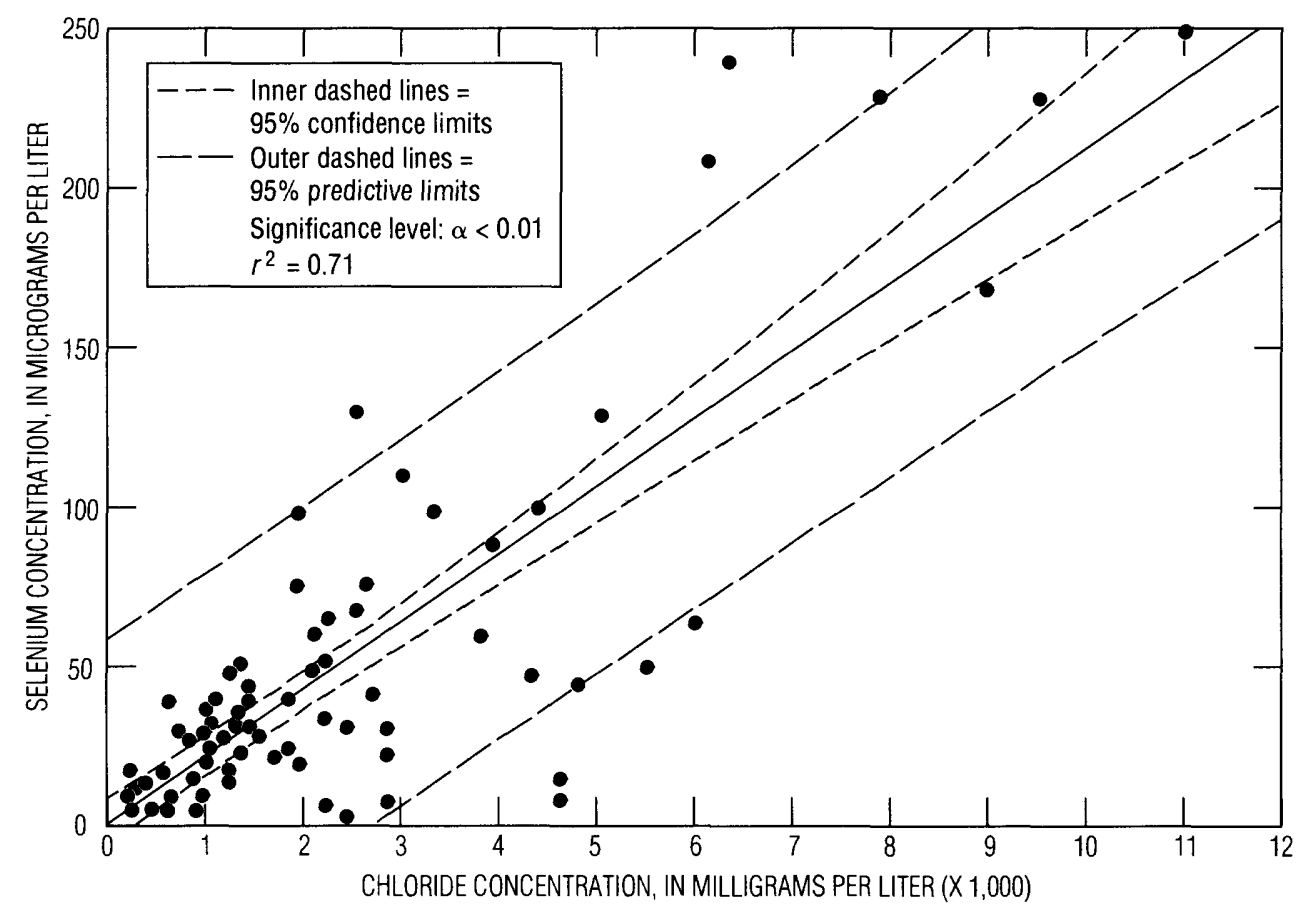

Figure 20. Regression plot of selenium and chloride concentrations for subsurface-drainwater samples collected in the Imperial Valley, May 1988.

unaffected by redox processes. In this study, evaporation is the physical process affecting both elements similarly. Analytical error at low ranges of selenium concentration can produce a substantial uncertainty in $\mathrm{Se} / \mathrm{Cl}$ ratio. Selenium concentration at site 8 (sump S-417), just south of the Salton Sea, was $340 \mu \mathrm{g} / \mathrm{L}$, among the highest selenium concentrations of the study. The chloride concentration at this site was $15,000 \mathrm{mg} / \mathrm{L}$, similar to that of the Salton Sea. These concentrations give a $\mathrm{Se} / \mathrm{Cl}$ ratio of $2.3 \times 10^{-5}$, close to that in the East Highline Canal. The similarity of the ratios indicates that selenium at greatly elevated levels can be accounted for by evaporative concentration of irrigation water.

The median $\mathrm{Se} / \mathrm{Cl}$ ratio for sites (sumps) in the Imperial Valley sampled during May 1988 is $2 \times 10^{-5}$ (fig. 21). The standard deviation for the sites is 1.5 . The minimum ratio is $0.027 \times 10^{-5}$ and the maximum is $7.3 \times 10^{-5}$, with 50 percent of the ratios falling between 1.0 and $3.0 \times 10^{-5}$.

Although most of the laboratory analyses done for this study were for total selenium (all oxidation states), selective sampling was done in June 1989 for determination of selenite-to-selenate ratio. (These analyses were done by USGS National Research

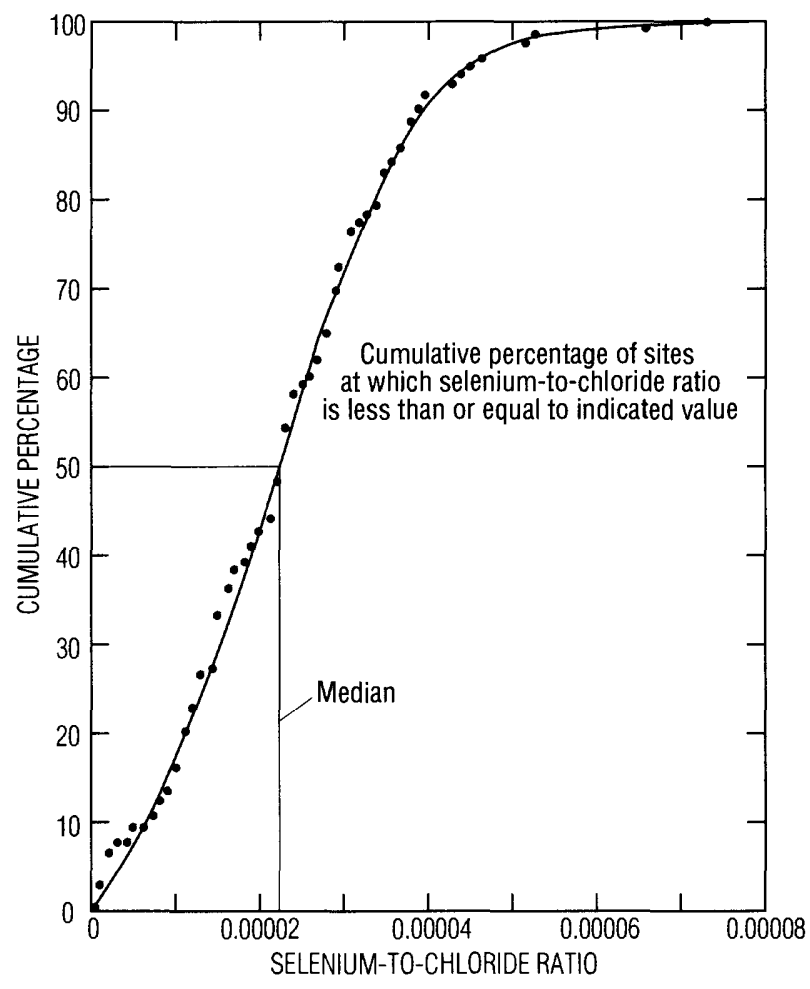

Figure 21. Selenium-to-chloride ratios in subsurface-drainwater samples collected at 108 sites in the Imperial Valley, May 1988. 


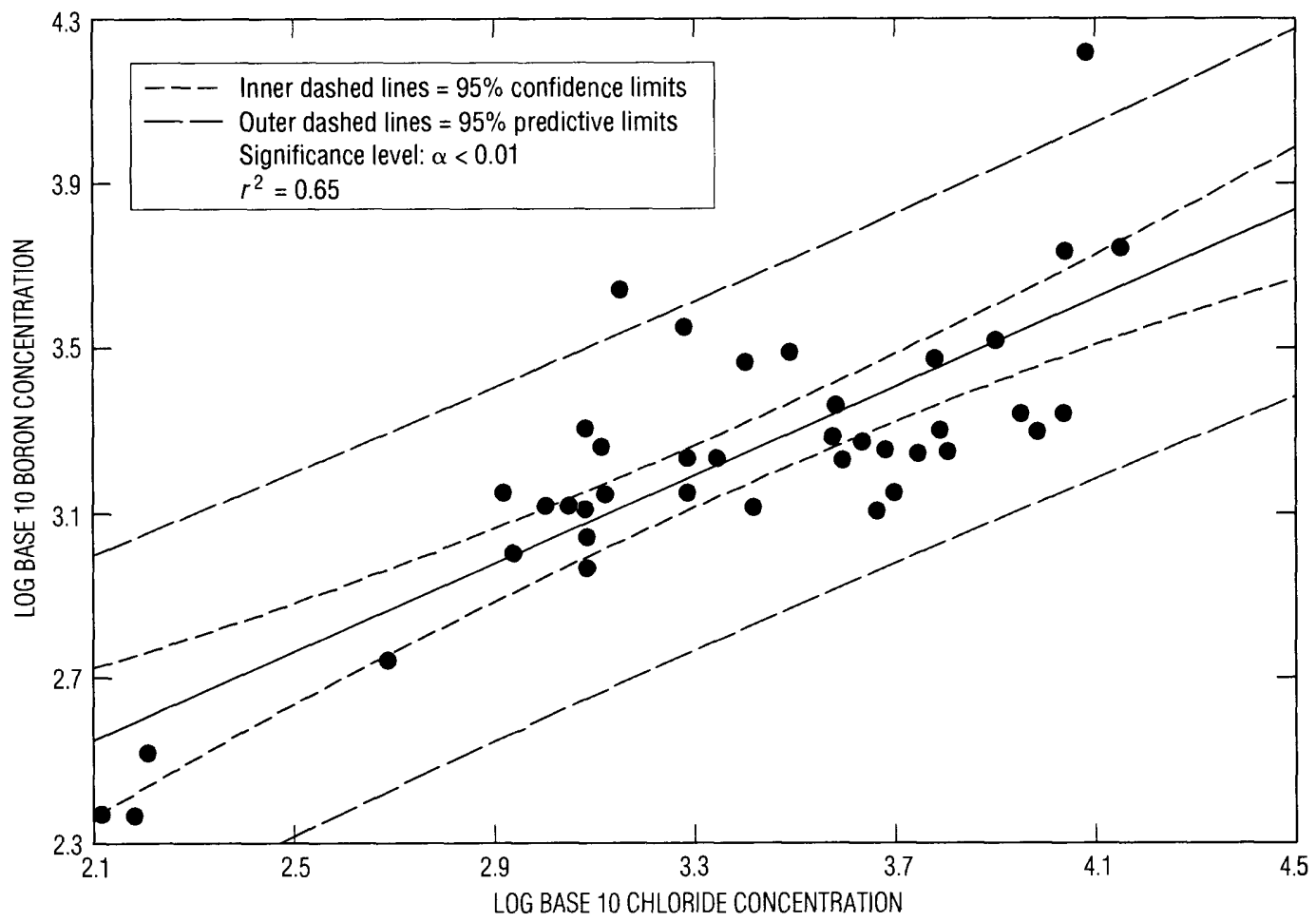

Figure 22. Regression plot of log base 10 boron and chloride concentrations for subsurface-drainwater samples collected in the Imperial Valley, May 1988.

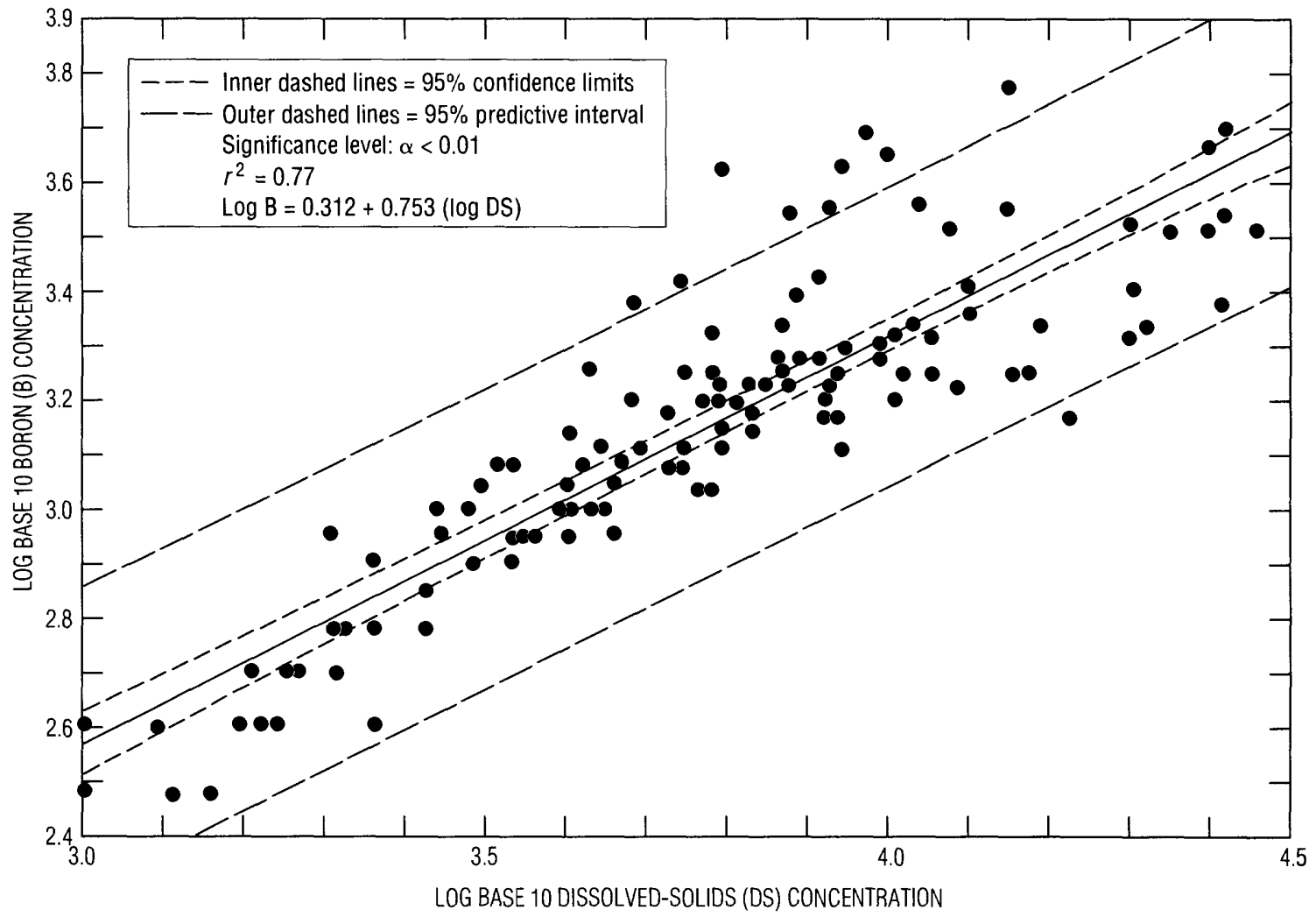

Figure 23. Regression plot of log base 10 boron and dissolved-solids concentrations for subsurface drainwater samples collected in the Imperial Valley, May 1988. (Samples collected by California Regional Water Quality Control Board, Region VII.) 
Program personnel in Menlo Park, California.) Water collected from site 8 , sump S-417, had a total selenium concentration of $275 \mu \mathrm{g} / \mathrm{L}$; of this total, $271 \mu \mathrm{g} / \mathrm{L}$ was in the highly soluble +6 or selenate form and only $4.24 \mu \mathrm{g} / \mathrm{L}$ was in the sparingly soluble +4 or selenite form. In comparison, water in the drainage ditch to which sump S-417 discharges had a total selenium concentration of $3.31 \mu \mathrm{g} / \mathrm{L}$. Of this total, $1.41 \mu \mathrm{g} / \mathrm{L}$ was in the form of selenite and $1.91 \mu \mathrm{g} / \mathrm{L}$ in the form of selenate, indicating that some reduction might be taking place in the drainage ditches.

\section{BORON}

Boron in subsurface drainage behaves in a manner similar to that of selenium in those areas where selenium remains in its +6 oxidation state. In the previous discussion of selenium in subsurface drainwater, it was shown that the correlation between $\delta \mathrm{D}$ and concentrations of $\mathrm{Se}$ and $\mathrm{Cl}$ indicated that evaporative concentration of Colorado River water was the primary process controlling soluble-salt concentration. Regression of boron against chloride for log-transformed data, demonstrates that evaporative concentration of Colorado River water is the principal process controlling boron concentrations in subsurface drainwater in the Imperial Valley $\left(r^{2}=\right.$ $0.65, \alpha<0.01$ ) (fig. 22). Regression between boron and dissolved-solids concentrations for the 1986 California Regional Water Quality Control Board collection from 119 sites confirms the strong relation between boron and evaporative concentration $\left(r^{2}=0.77, \alpha<0.01\right.$ for log-transformed data) (fig. 23).

\section{INTERACTION OF SUBSURFACE DRAINWATER AND SHALLOW GROUND WATER}

To explore the relation between shallow ground water and subsurface drainwater ${ }^{1}, 3$ fields were selected for installation of wells and lysimeters from the 15 where soil samples and monthly subsurface drainwater samples were collected. The three sites (northern, middle, and southern) were selected to be areally representative of the Imperial Valley and to cover a wide range in selenium concentration. Multiple-depth wells and lysimeters were installed at each site to determine the chemistry of shallow ground water. Water samples collected from these wells and lysimeters were analyzed for a large number of chemical constituents, including hydrogen and oxygen isotopes, selenium, nitrogen species (ammonia, nitrate plus nitrite, ${ }^{15} \mathrm{~N} /{ }^{14} \mathrm{~N}$ ), iron, manganese, boron, sulfur isotopes $\left({ }^{34} \mathrm{~S} /{ }^{\beta 2} \mathrm{~S}\right)$, dissolved solids, and tritium. Dissolved selenium, chloride, and sulfate were determined on pore water extracted from core samples collected during drilling.

Samples for analysis of hydrogen and oxygen isotopes were collected to determine the source of shallow ground water in the nested wells and lysimeters. Results of these analyses are shown in figure 24 , where $\delta D$ and $\delta^{18} \mathrm{O}$, in permil, are plotted along with the global meteoric water line. Historical isotope values for Salton Sea water (Craig, 1966) are included for comparison. The $\delta \mathrm{D}$ and $\delta^{18} \mathrm{O}$ of the Salton Sea samples increase with distance from the mouth of the major rivers toward the center of the sea, where the water is more saline (less diluted) and is, therefore, enriched isotopically by evaporation. In addition, the $\delta \mathrm{D}$ and $\delta^{18} \mathrm{O}$ of water in Lake Mead (Craig, 1966), the source of Colorado River water used for irrigation in the Imperial Valley, is shown (values are -114 and -14.5 permil, respectively). The evaporation line derived from drainwater clearly passes through samples from the Salton Sea and Lake Mead; the line also passes near the composition for shallow ground water at the three nested-well and lysimeter sites. The slope of a regression line using only ground-water data is 5.9, which compares favorably with the slope of 5.4 for subsurface drainwater in the Imperial Valley. The isotopic data indicate that the shallow ground water originates from the Colorado River, as does drainwater, and that it also has been subjected to evaporative concentration.

Stable-isotope ratios can show the effects of soil type on water quality beneath a field by indicating the degree to which evaporation occurs. The $\delta \mathrm{D}$ and $\delta^{18} \mathrm{O}$ of shallow ground water at the northern site (site 8 ), drained by sump 417 , indicate that the water is isotopically enriched (fig. 24). Values of $\delta \mathrm{D}$ and $\delta^{18} \mathrm{O}$ at a depth of $8 \mathrm{ft}$ were -80.5 and -8.1 permil, respectively. Although specific conductance was $70,000 \mu \mathrm{S} / \mathrm{cm}$ at $8 \mathrm{ft}$ and peaked at $84,000 \mu \mathrm{S} / \mathrm{cm}$ at $14 \mathrm{ft}, \delta \mathrm{D}$ and $\delta^{18} \mathrm{O}$ reached their maximum values of -59.5 and -5.15 permil, respectively, at $34 \mathrm{ft}$ below land surface. This shift in the relation between specific conductance and hydrogen and oxygen isotopes may be due to dissolution of evaporative salts deposited by historical lakes that occupied the Salton Trough. Soils in this area are classified as "Imperial silty clay, wet" (Soil Conservation Service, written

\footnotetext{
${ }^{1}$ Subsurface drainwater is defined here as water from land surface to a depth of about $6 \mathrm{ft}$. Shallow ground water is water from about $6 \mathrm{ft}$ below land surface to a depth of several hundred feet.
} 


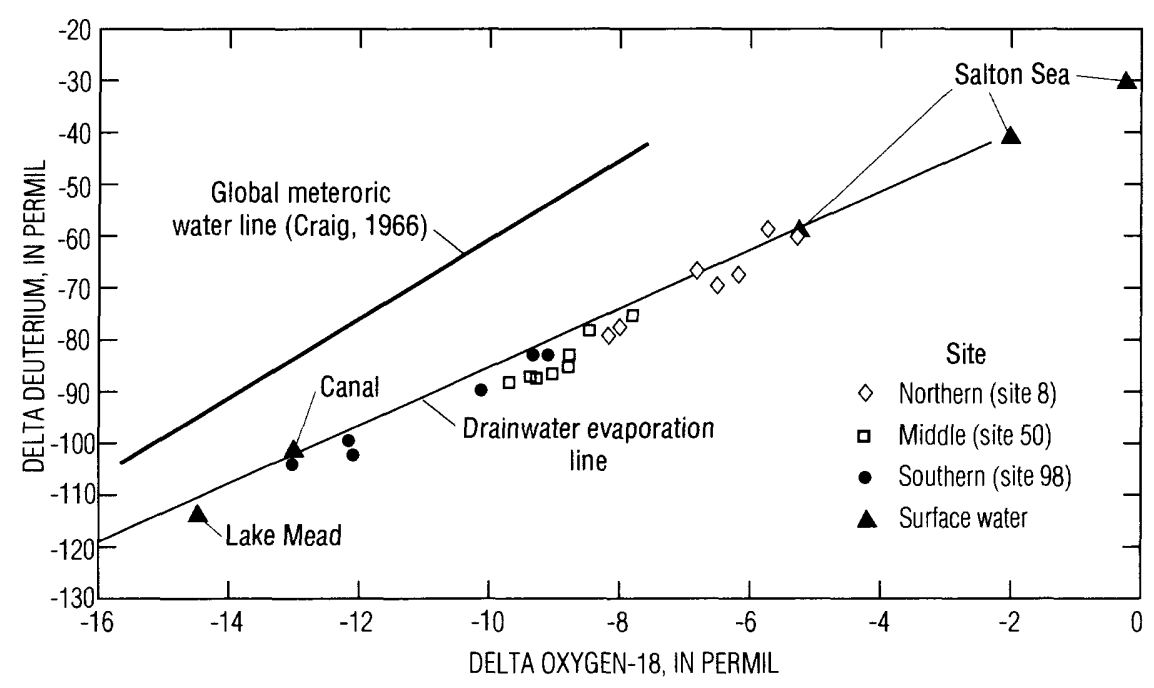

Figure 24. Hydrogen- and oxygen-isotope ratios and global meteoric water line for water samples from wells and lysimeters at three sites in the Imperial Valley. Samples from surface-water sites (from Craig, 1966, and Schroeder and others, 1993) are included for comparison.

commun., 1982). The effect of these clayey soils on water quality beneath the northern-site fields can be shown by comparing the isotopic ratios with those from the southern site. Greater evaporation at the northern site is indicated by higher (less negative) $\delta D$ and $\delta^{18} \mathrm{O}$ ratios (fig. 24), as well as by higher dissolved-solids concentration, in the shallow ground water (fig. 25).

The clayey soils at the northern site preclude significant penetration of irrigation water. Water from the upper lysimeter at the northern site at a depth of $8 \mathrm{ft}$ had a tritium concentration of $33 \mathrm{TU}$. At $14 \mathrm{ft}$, however, the tritium concentration decreased to 6.5 , at $19 \mathrm{ft}$ to 4.8 , and (in the shallow well) at 34 $\mathrm{ft}$ to $2 \mathrm{TU}$. The tritium concentration at $8 \mathrm{ft}$ indicates recent irrigation water; concentrations at $14 \mathrm{ft}$ and below indicate that only a minor amount of recent irrigation water reaches that depth and mixes with native water of pre-1952 origin. Water in sump S417 , which drains the field at the northern site, had a tritium concentration of $29.2 \mathrm{TU}$, equivalent to recent Colorado River water.

Periodic flooding of the Salton Trough by the Colorado River in the geologic past resulted in the formation of lakes. Water, trapped at different depths in the sediment of the Imperial Valley as a result of this episodic flooding, has been concentrated to varying salinities by evaporation. Recharge from the All-American Canal also is a source of local ground water, but it does not affect the geohydrology of the system below $100 \mathrm{ft}$ (Loeltz and others, 1975).
Water from the deepest well (199 ft) at the northern site (site 8 ) is isotopically similar to water at $8 \mathrm{ft}$, but the dissolved-solids concentrations differ considerably. Dissolved-solids concentration at $8 \mathrm{ft}$ was $57,300 \mathrm{mg} / \mathrm{L}\left(\delta \mathrm{D}=-80\right.$ permil and $\delta^{18} \mathrm{O}=-8.1$ permil), but at $199 \mathrm{ft}$ the concentration was 13,800 $\mathrm{mg} / \mathrm{L}\left(\delta \mathrm{D}=-78\right.$ permil and $\delta^{18} \mathrm{O}=-8.0$ permil $)$. Again, these differences in dissolved-solids concentration for water having virtually identical isotopic ratios probably are due to the dissolution of evaporative salts or to the operation of two different mechanisms of concentration: (1) evaporation of irrigation water in a shallow system, and (2) historical concentration in underflow and (or) older lake water in the regional ground-water system. The source of the water at both depths clearly is the Colorado River (fig. 24). Additionally, the isotopic composition of the water at $34 \mathrm{ft}$, where $\delta \mathrm{D}$ equaled -59 permil and $\delta^{18} \mathrm{O}$ equaled -5.2 permil, closely matches the composition (-60 and -5.2 permil) of water in the Salton Sea as determined by Craig (1966). The dissolvedsolids concentration of these two samples (the 34-foot sample and Craig's sample) also is similar (both about $34,000 \mathrm{mg} / \mathrm{L}$ ). Dissolved-solids concentration at the northern site decreased with depth to an apparent regional level of $13,800 \mathrm{mg} / \mathrm{L}$ at $199 \mathrm{ft}$.

The middle site, site 50 , is located in an area that in 1902 was identified as Mesquite Lake (Holmes and others, 1903). In the early 1900's, the Alamo River (at that time called the Salton River) flowed north from the international boundary to Mesquite Lake in an area of high-alkali soils about 3 mi northeast of the 


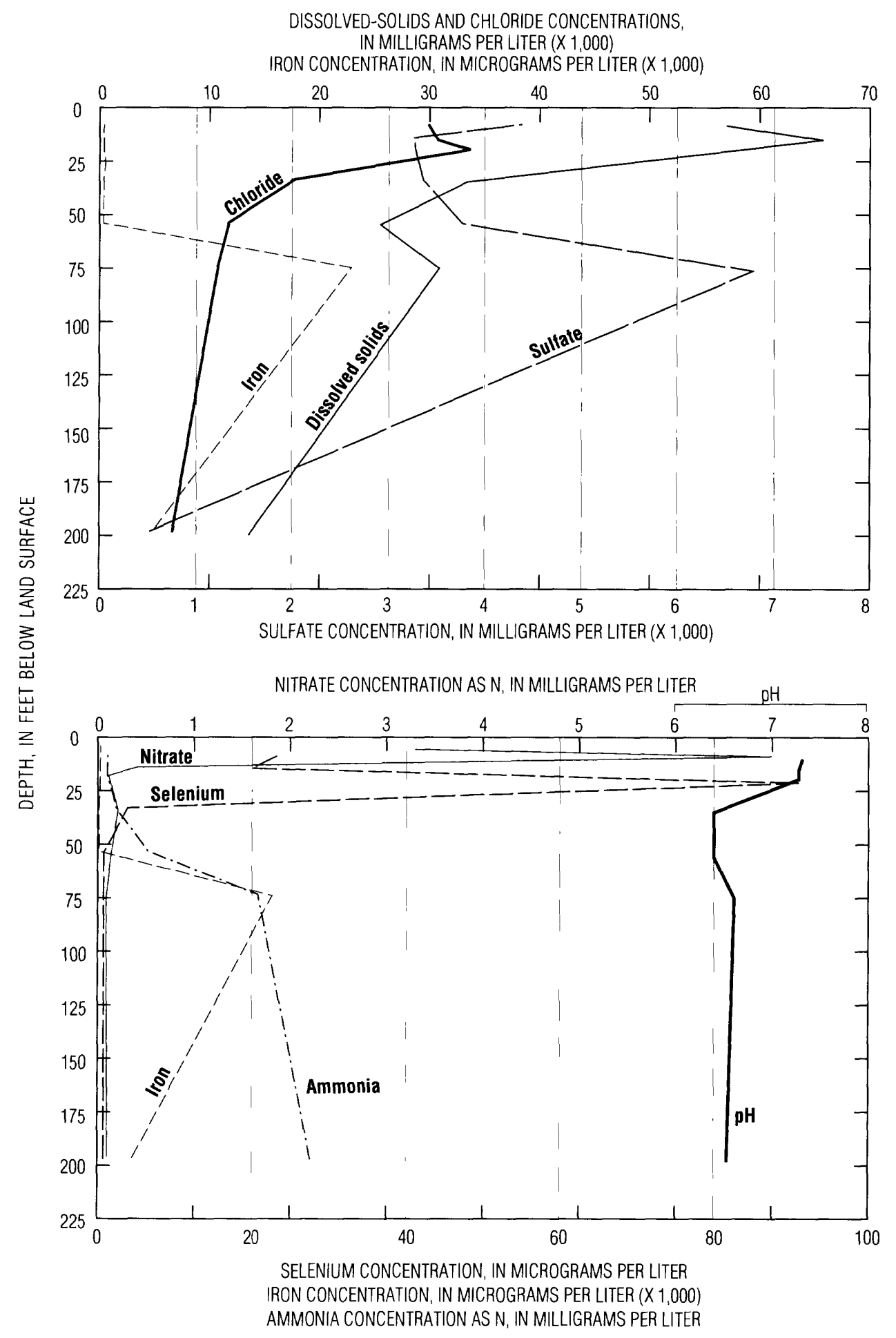

Figure 25. Concentrations of selected constituents, in relation to depth, for water samples collected from wells and lysimeters at the northern site (site 8) in the Imperial Valley.

town of Imperial (Holmes and others, 1903, p. 1238). The soil in this area is classified as "Imperial silty clay, saline" (Soil Conservation Service, written commun., 1982). This is the only area in the Imperial
Valley, not under water, where the soil is designated as saline. Hydrogen- and oxygen-isotope ratios in water samples collected from nested wells and from lysimeters at this site plot on the evaporative con- 

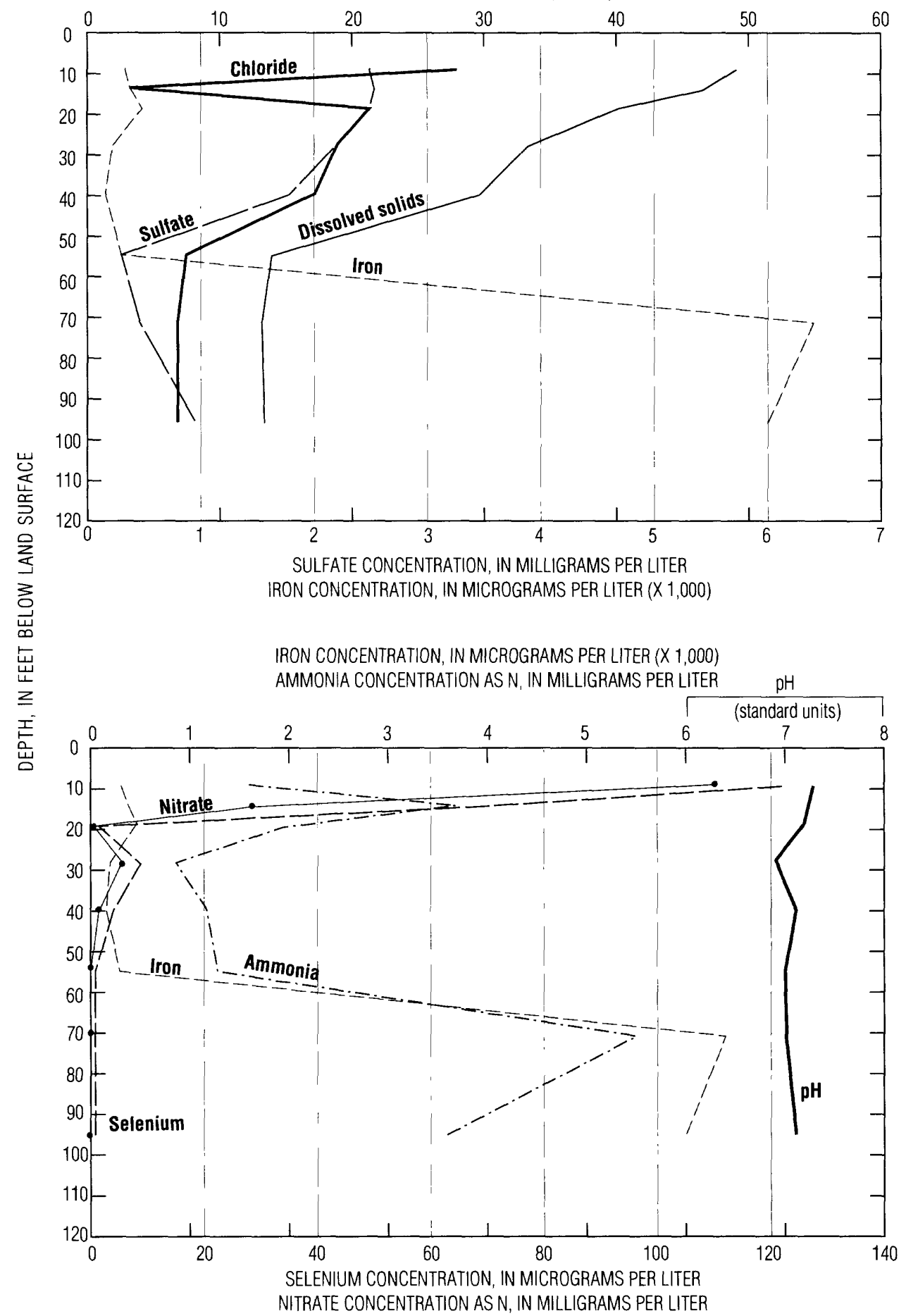

Figure 26. Concentrations of selected constituents, in relation to depth, for water samples collected from wells and lysimeters at the middle site (site 50 ) in the Imperial Valley.

centration line shown in figure 24 , indicating that water at the middle site also is derived from the Colorado River. The median $\delta \mathrm{D}$ and $\delta^{18} \mathrm{O}$ values of -87 and -9.1 permil fall between the medians from the southern and northern sites of -91 and -11.35 and -68 and -6.5 permil, respectively. Although not as highly evaporated as at the northern site, water at the middle site nevertheless has high dissolved-solids concen- 


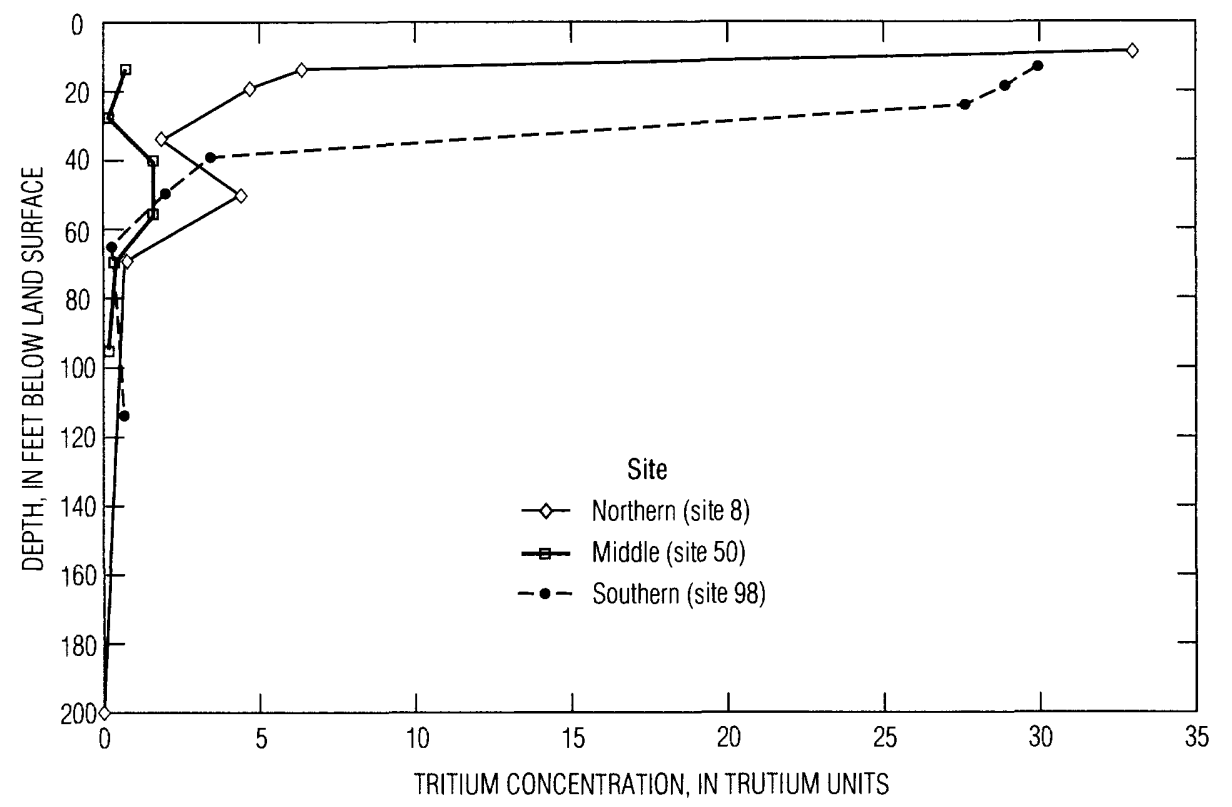

Figure 27. Concentration of tritium in water samples from lysimeters and wells at three sites in the Imperial Valley. Location of sites is shown in figure 9.

trations (for example, $49,500 \mathrm{mg} / \mathrm{L}$ at a depth of $9 \mathrm{ft}$ ) (fig. 26). Because this field is in a localized topographic depression in a fairly recent (early 1900's) lakebed, evaporative salts present in the soils may be leached by heavy flushing of the field to make a suitable environment for growing crops. In spite of the added salt input from dissolution of evaporated salts present in the soils, the correlation of $\delta^{18} \mathrm{O}$ with dissolved-solids concentration, $r^{2}=0.87$, is high. In a manner similar to that at the northern site (and southern site, discussed later), the dissolved-solids concentration at the middle site decreases with depth and approaches a regional level of about 13,000 $\mathrm{mg} / \mathrm{L}$.

Tritium concentrations in water from lysimeters and wells beneath the middle site indicate that no recent irrigation water has percolated past a depth of $14 \mathrm{ft}$ (fig. 27). The tritium concentration at $14 \mathrm{ft}$ was $0.6 \mathrm{TU}$, indicating the absence of recent water. At 40 and $55 \mathrm{ft}$, low levels of tritium, 1.7 and $2.3 \mathrm{TU}$, respectively, were detected; however, these concentrations are believed to be artifacts from incomplete well development (see Schroeder and others, 1993, for additional information). Tritium concentration in the sump (S-154) draining the middle site was $33.4 \mathrm{TU}$, a little greater than that of present-day Colorado River water.

Composition of soils at the southern site (site 98) is 70 percent Imperial-Glenbar silty clay loam, wet; 20 percent Meloland very fine sandy loam, wet; and
10 percent Holtville silty clay, wet (Zimmerman, 1981). Water samples from the two lysimeters at depths of 12 and $18 \mathrm{ft}$ and from the shallow well at $23 \mathrm{ft}$ show that little evaporative concentration has occurred ( $\delta \mathrm{D}$ of $-99.5,-102$, and -103.5 permil, and $\delta^{18} \mathrm{O}$ of $-12.2,-12.1$, and -13 permil, respectively). However, the lysimeters are located in an area strongly affected by tailwater runoff. The water in the lysimeters and shallow well (at depths of 12 to 23 $\mathrm{ft}$ ) had dissolved-solids concentrations of 2,140, 1,350 , and $1,450 \mathrm{mg} / \mathrm{L}$ (fig. 28). These concentrations are not indicative of the subsurface drainwater in the field. Dissolved-solids concentration in water from sump S-371 was $9,170 \mathrm{mg} / \mathrm{L}$ (average for 12 monthly samples). At $39 \mathrm{ft}$, however, higher (less negative) $\delta \mathrm{D}$ and $\delta^{18} \mathrm{O}$ values (-96 and -11.35 permil) indicate that evaporation has occurred.

Tritium concentrations (fig. 27) confirm that water at the southern site from land surface to a depth of 23 $\mathrm{ft}$ is from recent irrigation. At $12.5,18$, and $23 \mathrm{ft}$, the tritium concentrations were 29.9, 28.9, and $27.7 \mathrm{TU}$, respectively. These concentrations are similar to current Colorado River tritium concentrations of 30 TU (fig. 29). As depth increases, tritium concentration decreases to $3.6 \mathrm{TU}$ at $39 \mathrm{ft}, 2.1 \mathrm{TU}$ at $49 \mathrm{ft}$, and 0.4 and $0.8 \mathrm{TU}$ at 65 and $114 \mathrm{ft}$, respectively. Water $65 \mathrm{ft}$ and deeper is effectively free from tritium, indicating a pre-1952 source.

The use of elemental ratios such as $\mathrm{Se} / \mathrm{Cl}$ in demonstrating the similarity of subsurface drainwater 


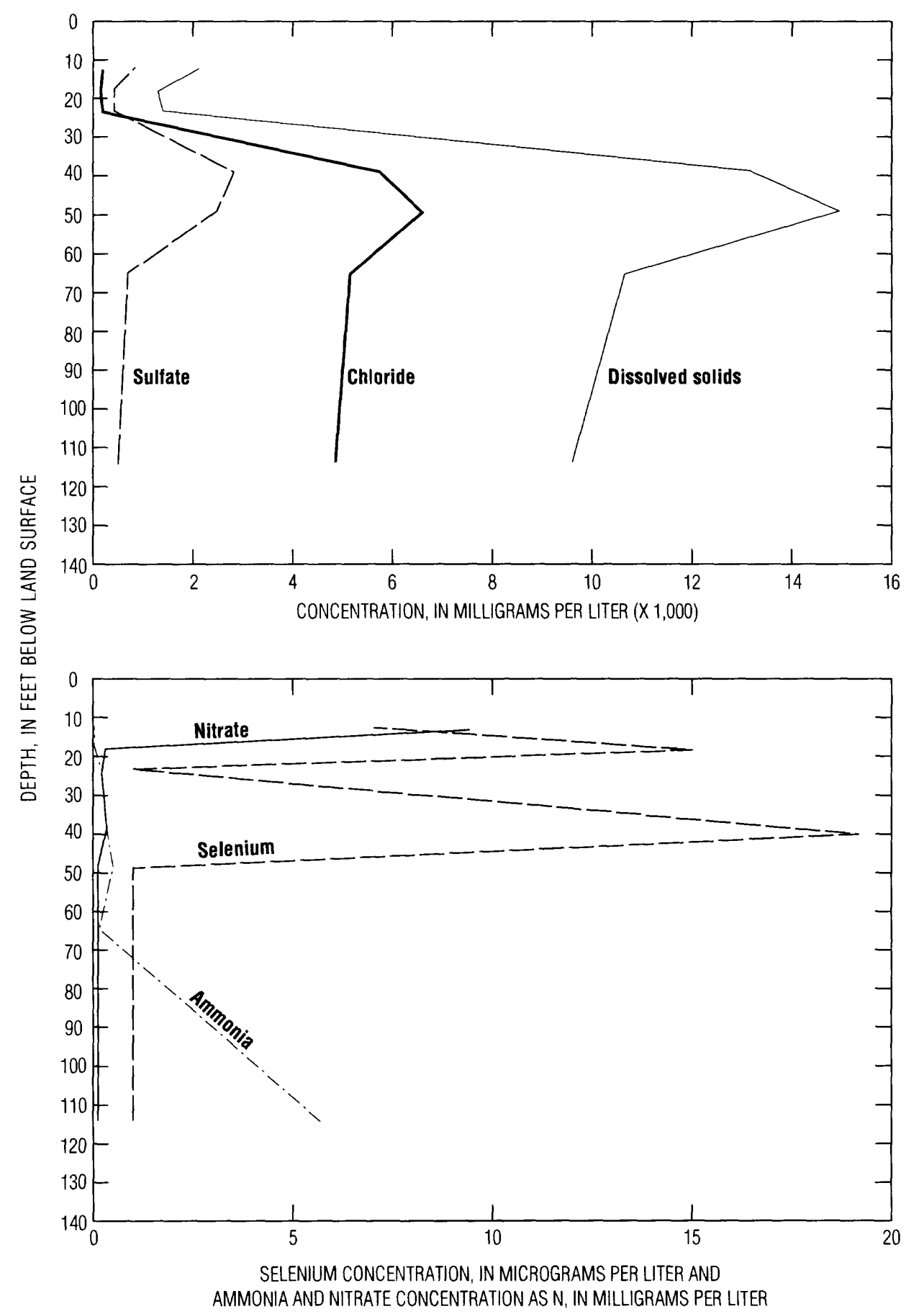

Figure 28. Concentrations of selected constituents, in relation to depth, for water samples from wells and lysimeters at the southern site (site 98) in the Imperial Valley.

in the Imperial Valley is not applicable to most ground-water samples collected during this study. Reducing conditions at depth may transform the selenium present as $\mathrm{SeO}_{4}^{2-}$ to $\mathrm{SeO}_{3}^{2-}$ or to $\mathrm{Se}^{\circ}$ and $\mathrm{Se}^{2-}$. The reduced compounds can be adsorbed to the soils and control the selenium solubility (Neal and others, 1987; Elrashidi and others, 1987).
Shallow-ground-water chemistry at the three nested-well and lysimeter sites demonstrates the effects of the ongoing chemical, biological, and geohydrological processes beneath the fields. These reactions occur under a variety of redox conditions, as shown by the relation between selected constituents. Because artesian conditions are present throughout 


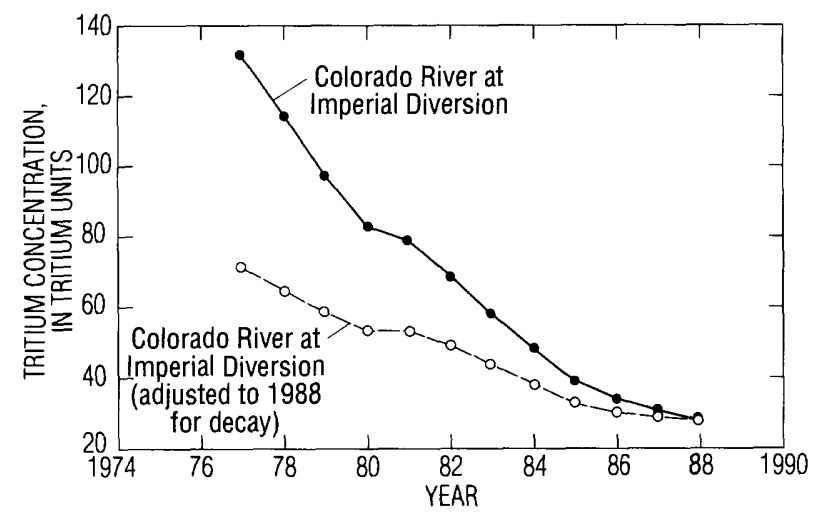

Figure 29. Concentration of tritium in water samples from the Colorado River, 1977-88.

much of the Imperial Valley, shallow ground water represents a potential source of discharge to either the subsurface drains or the drainage ditches, and therefore to the Salton Sea, the terminus of these drains and ditches.

The quality of water in the nested wells and lysimeters at the northern site changes significantly with depth. The well at $75 \mathrm{ft}$ is perforated in a sandy layer several feet thick that is overlain and underlain by virtually impervious clays. Artesian conditions are present in this zone-which is supersaturated with respect to carbon dioxide. The carbon dioxide effervesces on exposure to the atmosphere, and calcite forms in the bottom of sample bottles (the precipitate bubbles and dissolves completely on addition of acid). This sandy layer at $75 \mathrm{ft}$ most likely has some continuity with the carbon dioxide-emitting mud volcanoes (Loeltz and others, 1975) along the southeastern edge of the Salton Sea. Water at depth in the geothermal system (brines) are high in sodium, calcium, potassium, boron, lithium, barium, zinc, lead, and copper (Helgeson, 1968, p. 131). Perhaps, some influence of the geothermal system is seen in water from the artesian zone.

Water-quality analyses indicate that the artesian zone apparently affects water in the overlying zone. Another possible explanation, however, is contamination of the upper wells as a result of incomplete seals in the annulus of the hole. Each well was perforated, in a 5-foot interval, at the bottom of the PVC casing and the annulus was packed with sand. The interval to the next well point was sealed with bentonite chips. Water from this highly pressurized system might force its way through the well seal, thereby contaminating the shallower wells, although variations in the water-quality profile (fig. 26) would seem to indicate that any such contamination is slight.
The effects of reducing conditions on concentrations of selenium and other redox-sensitive constituents in shallow ground water are shown in figure 25. Examined were the constituents selenium, ammonia, nitrate, and iron, along with $\mathrm{pH}$. Selenium concentrations at the northern site increased beneath the field from 24 and $20 \mu \mathrm{g} / \mathrm{L}$ at 8 and $14 \mathrm{ft}$, respectively, to $90 \mu \mathrm{g} / \mathrm{L}$ at $19 \mathrm{ft}$ and show a trend similar to that of dissolved solids in this interval. Below $19 \mathrm{ft}$, however, selenium concentration decreases to $4 \mu \mathrm{g} / \mathrm{L}$ at $34 \mathrm{ft}, 1 \mu \mathrm{g} / \mathrm{L}$ at $54 \mathrm{ft}$, and less than $1 \mu \mathrm{g} / \mathrm{L}$ at 75 and $199 \mathrm{ft}$. This decrease in selenium concentration corresponds to an increase in ammonia concentration. The increasing presence of ammonia indicates that reducing conditions become more pronounced as depth increases. Under reducing conditions, nitrate is converted to ammonia, and selenate can be converted to selenite, elemental selenium, or selenide, depending on the environmental conditions (soil acidity or alkalinity, $\mathrm{pH}, \mathrm{pE}$, and biota present). At $75 \mathrm{ft}$, the nitrate concentration is less than $0.1 \mathrm{mg} / \mathrm{L}$, and the ammonium concentration has increased to $21 \mathrm{mg} / \mathrm{L}$. The increase in ammonia concentration corresponds to an increase in iron concentration from $340 \mu \mathrm{g} / \mathrm{L}$ at 54 $\mathrm{ft}$ to $23,000 \mu \mathrm{g} / \mathrm{L}$ at $75 \mathrm{ft}$. The high iron and ammonium concentrations, in concert with the lessthan-detection-limit nitrate and selenium, indicate a reducing environment. According to Elrashidi and others (1987), "Under highly reducing conditions, selenides are the major inert sink of Se introduced into the environment. Contamination of water or soil by these minerals poses a minimal hazard of $\mathrm{Se}$ toxicity so long as their depository remains reduced." Concentrations of manganese ranged from $210 \mu \mathrm{g} / \mathrm{L}$ at $199 \mathrm{ft}$, where reducing conditions prevailed, to $11,000 \mu \mathrm{g} / \mathrm{L}$ at $14 \mathrm{ft}$, where selenium and nitrate still were present.

Of particular interest was the finding of elevated levels of arsenic at depth in the Imperial Valley. During the reconnaissance investigation of the Salton Sea area, elevated levels of arsenic were not found in either subsurface drainwater or in bottom sediment. [Median arsenic concentration in bottom sediment was $5.6 \mathrm{mg} / \mathrm{kg}$; for comparison, the maximum baseline concentration for 95 percent of soils in the Western United States is $22 \mathrm{mg} / \mathrm{kg}$. Arsenic concentration in subsurface drainwater ranged from 1 to $4 \mu \mathrm{g} / \mathrm{L}$, considerably less than the $50 \mu \mathrm{g} / \mathrm{L}$ criterion (U.S. Environmental Protection Agency, 1986) for protection of aquatic life.] Arsenic concentration in shallow ground water at and above $54 \mathrm{ft}$ ranged from 2 to 9 $\mu \mathrm{g} / \mathrm{L}$. At $75 \mathrm{ft}$, however, the concentration increased to $91 \mu \mathrm{g} / \mathrm{L}$, and at $199 \mathrm{ft}$ the concentration was 
$67 \mu \mathrm{g} / \mathrm{L}$. Although the source of this arsenic is unknown, there is some moderate geothermal influence at these depths that might account for the increase. According to Welch and others (1988), "Geothermal water generally has higher arsenic concentrations than non-thermal ground water with the highest concentrations found in brines such as those found in the Salton Sea geothermal area." Water temperature increases with depth from $30^{\circ} \mathrm{C}$ at $54 \mathrm{ft}$ to $31.5^{\circ} \mathrm{C}$ at $75 \mathrm{ft}$ and $36^{\circ} \mathrm{C}$ at $199 \mathrm{ft}$. The wells at 75 and $199 \mathrm{ft}$ are artesian and likely have continuity with the carbon dioxide-producing system along the southeastern edge of the Salton Sea.

At the middle site, concentrations of constituents indicative of redox conditions also exhibit a pattern similar to that of the northern site (figs. 25, 26). Selenium and nitrate concentrations decrease with depth. Regression of selenium against nitrate yields an $r^{2}$ of 0.93 , indicating that similar processes affect both selenium and nitrate. Ammonia, another indicator of redox conditions, does not present any clear pattern in concentration. Nevertheless, at $55 \mathrm{ft}$, both selenium and nitrate have been reduced to less than reporting limits, $1.0 \mu \mathrm{g} / \mathrm{L}$ and $0.1 \mathrm{mg} / \mathrm{L}$, respectively. In a manner similar to that at the northern site, iron concentrations in the two artesian zones ( 71 and $95 \mathrm{ft}$ ) indicate reducing conditions. Iron concentration increased from $310 \mu \mathrm{g} / \mathrm{L}$ at $55 \mathrm{ft}$ to $6,400 \mu \mathrm{g} / \mathrm{L}$ at 71 $\mathrm{ft}$ and $6,000 \mu \mathrm{g} / \mathrm{L}$ at $95 \mathrm{ft}$.

The patterns of arsenic concentration with depth at the middle site also were analogous to those at the northern site. The shallow-depth lysimeters and wells had low arsenic concentrations that ranged from 2 to $7 \mu \mathrm{g} / \mathrm{L}$. The two deeper wells in the artesian zone had concentrations of $46 \mu \mathrm{g} / \mathrm{L}$ at $71 \mathrm{ft}$ and $59 \mu \mathrm{g} / \mathrm{L}$ at $95 \mathrm{ft}$. Unlike the northern site, where a thermal gradient is present that might indicate geothermal influence, no such temperature gradient is apparent at the middle site. Although the geothermal gradient decreases quickly south of the northern site, other thermal anomalies are present in the southern Imperial Valley that could influence the temperature gradient (Helgeson, 1968, p. 158).

Concentration patterns of redox-indicating species in water from the nested wells and lysimeters at the southern site differ somewhat from patterns at the northern and middle sites (figs. 25, 26), because water in the lysimeters and shallow wells at the southern site was strongly influenced by tailwater runoff and (or) by the irrigation canal. However, the redoxrelated pattern of selenium and nitrate disappearance associated with increased ammonia in the deeper wells is identical to the pattern at the northern and middle sites.

\section{MOVEMENT AND PARTITIONING OF SELENIUM IN THE SALTON SEA}

As discussed previously, selenium is transported, in low levels, in water supplied for irrigation; concentrated by evaporation in the fields of the Imperial Valley to levels as high as $360 \mu \mathrm{g} / \mathrm{L}$; and transported to the Salton Sea by the New and Alamo Rivers, as well as by several drains and drainage ditches that discharge directly to the sea. Selenium, at a discharge-weighted concentration of $25 \mu \mathrm{g} / \mathrm{L}$ in subsurface drainwater, is diluted by low-concentration tailwater and canal seepage to concentrations of 4 and $8 \mu \mathrm{g} / \mathrm{L}$, respectively, in the New and Alamo Rivers at their outlets to the Salton Sea. Samples collected in the delta of the Alamo River and in the Salton Sea indicate that selenium is being removed from the inflowing water. An improved understanding of the selenium-removal process has been a high priority for research since selenium contamination and adverse effects on waterfowl and shorebirds were documented at Kesterson National Wildlife Refuge (California). The subsequent discovery of selenium contamination in the Tulare Basin (California), Stillwater Wildlife Management Area (Nevada), Stewart Lake Waterfowl Management Area and Ouray National Wildlife Refuge in the Middle Green River Basin (Utah), and Kendrick Reclamation Project area (Wyoming), has provided impetus for continuing research.

Previous studies (Cooke and Bruland, 1987) indicated that the main selenium-removal process centered around the incorporation of selenium into biological particles that settle to the bottom of the water body and degrade, releasing dimethyl selenide. This degassing of dimethyl selenide was one mechanism considered, along with the settling of the seleniumcontaining biota, to explain selenium removal from the water column. In this degassing mechanism, selenium is an analog for sulfur. Current research, however, indicates that the removal rates engendered by these processes are not sufficient to account for the magnitude of selenium removal in water bodies such as the Salton Sea (Oremland and others, 1990, p. 1163). This research has identified a sulfateindependent process whereby selenate is reduced to elemental selenium by anaerobic bacteria (Oremland and others, 1989, p. 2340). These bacteria use selenate as a preferential electron acceptor. Nitrate acts as a competitive electron acceptor that interferes with this biochemical reduction of selenium. Although 


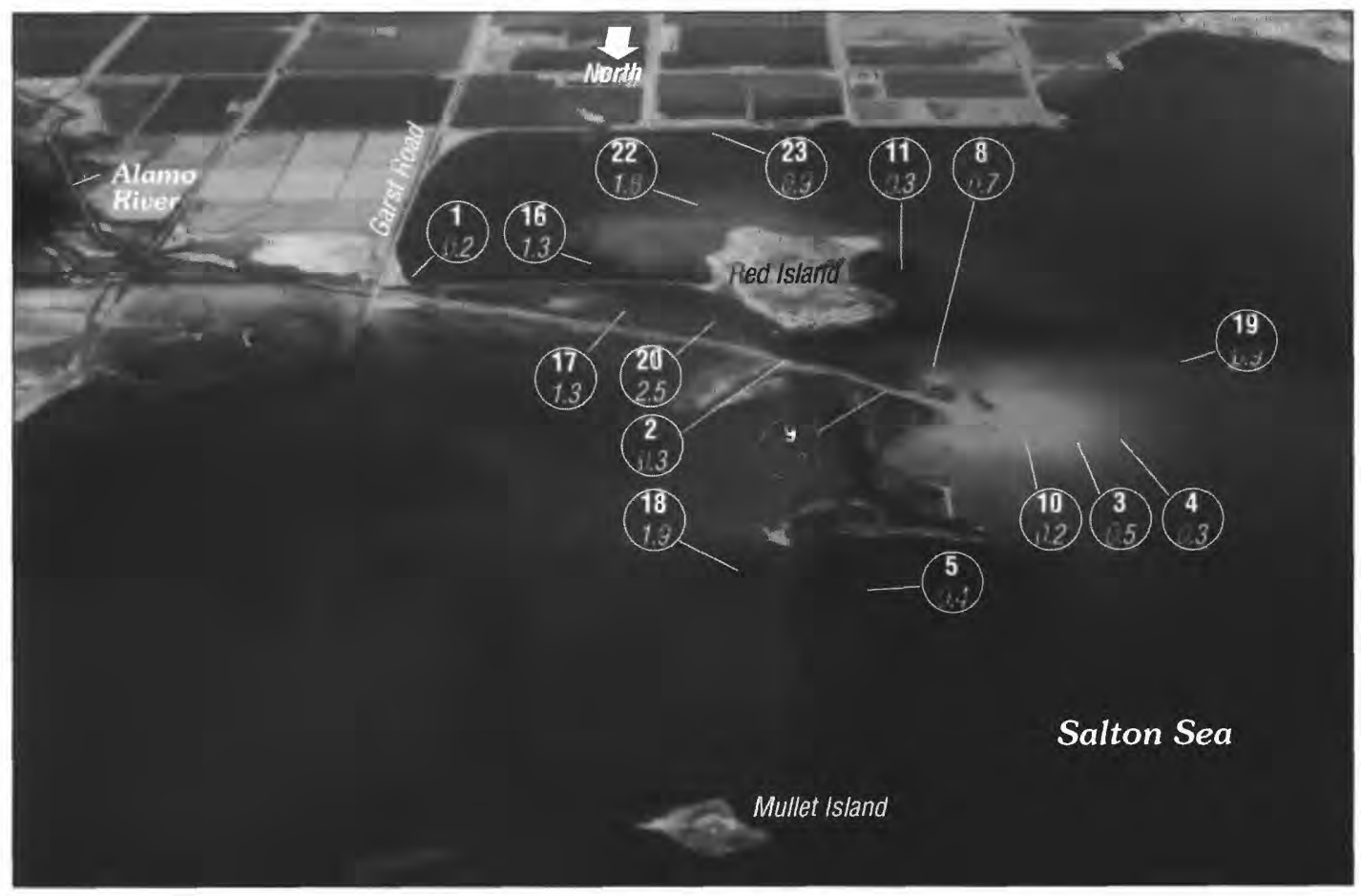

EXPLANATION

5- Site number

0.4 Selenium concentration - In milligrams per kilogram

Figure 30. Areal distribution of selenium in bottom sediment in the delta area of the Alamo River at the southern end of the Salton Sea, August 1988.

selenate is removed from the water, this removal does not necessarily mean that selenium is no longer a contaminant. According to R.S. Oremland (USGS, written commun., 1990):

The fact that this [selenium removal] occurs independently of the abundant molecular analog (for example, sulfate) allows for the reaction to be the major selenium sink in the presence of high dissolved sulfate (about 300 millimoles). Nonetheless, we hypothesize that accumulation of elemental $\mathrm{Se}$ in surficial sediments of impacted regions does not necessarily remove this toxicant from the food chain. Ingestion by sediment-feeding organisms, as well as oxidation or further reduction by chemical or biological means will still pose a threat to the ecosystem.

Water-quality sampling in the delta area of the Alamo River was done to determine type and location of the interface between the river and the Salton Sea and the partitioning of selenium between the water and sediment. Water and bottom-sediment samples were collected and specific conductance, $\mathrm{pH}$, temperature, and dissolved oxygen were measured in August 1988, February 1989, and August 1989. Bottom sediment, however, was not analyzed for the August 1989 sampling. Sample-site locations and selenium concentrations in the bottom sediment in August 1988 are shown in figure 30 . Because the reporting limit for aqueous selenium is $1 \mu \mathrm{g} / \mathrm{L}$ and the selenium concentration in the Salton Sea is about 1 $\mu \mathrm{g} / \mathrm{L}$, little information about selenium processes could be determined from areal water sampling of the Salton Sea.

A narrow zone of mixing between high-salinity Salton Sea water and low-salinity river water is present at site 10 (see location in fig. 30) about 200 $\mathrm{ft}$ seaward of the end of the levee on the left bank of the Alamo River. Water at this site was less than 3 $\mathrm{ft}$ deep. The specific conductance at a depth of $1.3 \mathrm{ft}$ was $5,000 \mu \mathrm{S}$ at a temperature of $30.9^{\circ} \mathrm{C}$ and a dissolved-oxygen concentration of $4.2 \mathrm{mg} / \mathrm{L}$ (56 percent saturation). At the bottom (about $3 \mathrm{ft}$ ), the specific conductance was $51,000 \mu \mathrm{S}$ at a temperature of $30.3^{\circ} \mathrm{C}$ and a dissolved-oxygen concentration of $1.2 \mathrm{mg} / \mathrm{L}$ (18 percent saturation). The selenium concentrations were $8 \mu \mathrm{g} / \mathrm{L}$ at $1.3 \mathrm{ft}$ and less than 
$1.0 \mu \mathrm{g} / \mathrm{L}$ at $3 \mathrm{ft}$. These data indicate that relatively high-selenium river water is mixed with and diluted (with respect to selenium concentration) by the lowselenium Salton Sea water-and, conversely, the lowsalinity river water becomes concentrated (with respect to salinity) by the high-salinity water of the Salton Sea. A few selected samples that were collected to determine oxidation state indicate that selenium in the Alamo River, on the river side of the interface (between sites 9 and 10), is a mixture of selenate and selenite. The total-selenium concentration measured at this site during the June 1989 sampling was $6.35 \mu \mathrm{g} / \mathrm{L}$, with $2.56 \mu \mathrm{g} / \mathrm{L}$ as $\mathrm{Se}(+4)$ and $3.79 \mu \mathrm{g} / \mathrm{L}$ as $\mathrm{Se}(+6)$. These concentrations show that a significant proportion of the selenium flowing into the Salton Sea is in an intermediate $(+4)$ and the highly oxidized $(+6)$ oxidation state. At the interface (site 10), total selenium is less than the reporting limit of $2.4 \mu \mathrm{g} / \mathrm{L}$ (method specific for June 1989 sample); $\mathrm{Se}(+4)$ is $1.79 \mu \mathrm{g} / \mathrm{L}$; and $\mathrm{Se}(+6)$ is less than the reporting limit of $0.2 \mu \mathrm{g} / \mathrm{L}$. These results indicate that virtually none of the selenium on the Salton Sea side of the interface is in the highly oxidized (+6) oxidation state.

Water-quality measurements made throughout the delta area indicate that some stratification is present in the water column. Dissolved-oxygen saturation indicates a eutrophic system in which oxygen saturation is greater than 100 percent during daylight hours. The night of August 24, 1988, a tropical storm swept through the Imperial Valley carrying high wind and heavy rainfall. Although the prevailing winds are out of the northwest, winds in this storm were from the southwest. Observations made the morning of August 25,1988 , indicated that algal mats from the southern embayments were carried toward the main body of the Salton Sea. As the prevailing winds reestablished, a ring of dead fish was observed off the delta of the Alamo River. Measurements of dissolved-oxygen concentration during the morning of August 25 revealed that oxygen saturations were substantially lower than those normally observed (less than 30 percent of normal) during daytime. Conditions returned to normal later on August 25 as the prevailing northwest winds blew the algal mats back into the embayments on the southern end of the Salton Sea. Bottom sediment in the southern end of the Salton Sea generally is anaerobic. Sediment stirred up by the storm exerted an immediate oxygen demand on the overlying water column, resulting in lowered levels of oxygen saturation. To demonstrate this effect, dissolved-oxygen concentration was measured at site 17 on February 16, 1989, and found to be 35.6 $\mathrm{mg} / \mathrm{L}$, at a saturation of 356 percent. The bottom sediment then was agitated, and dissolved-oxygen concentration was remeasured. The remeasurement indicated that dissolved-oxygen concentration had decreased to $21.1 \mathrm{mg} / \mathrm{L}$ and oxygen saturation had decreased to 214 percent.

Measurements made during the winter indicate the expected changes in water temperature, but other measured properties and constituent concentrations were similar to those found during the summer. The mixing zone was located in the same area, although the depth was only $2 \mathrm{ft}$. Specific conductance at the surface was $7,400 \mu \mathrm{S}$, dissolved-oxygen concentration was $12.2 \mathrm{mg} / \mathrm{L}$ (saturation 112 percent), and selenium concentration was $8 \mu \mathrm{g} / \mathrm{L}$. Near the bottom at $2 \mathrm{ft}$, the specific conductance ranged from 34,000 to $40,000 \mu \mathrm{S}$, and dissolved-oxygen concentration was $21.9 \mathrm{mg} / \mathrm{L}$ (210 percent saturation).

Bottom-sediment samples were collected at sites throughout the Alamo River delta area. Results for these samples are reported as total-selenium concentration, in milligrams per kilogram (or parts per million). Selenium concentrations in bottom sediment from the Alamo River were $0.2 \mathrm{mg} / \mathrm{kg}$ at site 1 (Garst $\mathrm{Road}$ ) and $0.3 \mathrm{mg} / \mathrm{kg}$ at site 2 (see fig. 30). At the remaining delta-area sites, selenium concentration in bottom sediment ranged from 0.2 to $2.5 \mathrm{mg} / \mathrm{kg}$. Although two adjacent sites in an embayment had relatively high selenium concentrations, 1.3 and 2.5 $\mathrm{mg} / \mathrm{kg}$, there was no apparent pattern to the areal distribution.

\section{EFFECTS OF SELENIUM AND OTHER CONSTITUENTS ON BIOTA}

\section{SELENIUM}

Irrigation drainwater has contributed to the enrichment of selenium in water, sediment, and biota throughout the Imperial Valley (Setmire and others, 1990). Elevated concentrations of selenium also have been detected at other drainwater projects throughout the Western United States (Sylvester and others, 1989). When found in excessive amounts, selenium is of concern because it has been linked directly to lethal and sublethal effects on fish and wildlife (Ohlendorf, 1989).

One of the most important aspects of selenium toxicity in aquatic systems is the ability of organisms to accumulate selenium to concentrations much 
greater than concentrations in water, sediment, or food items. Therefore, adverse effects to fish and wildlife can occur even if selenium concentrations in water are low. Extensive bioaccumulation, which occurs throughout the food chain, results because selenium is an essential micronutrient and is chemically similar to sulfur (Lemly and Smith, 1987). Bioaccumulation of selenium in birds from elevated dietary levels has been found to impair reproduction (Ort and Latshaw, 1978; Eisler, 1985; Heinz and others, 1989; Ohlendorf, 1989). Field studies in areas of seleniumladen agricultural drainwater have shown embryonic mortality and deformities in water birds attributable to the adverse effects of selenium (Ohlendorf and others, 1986a, 1986b; Schroeder and others, 1988; Ohlendorf and Skorupa, 1989). One of the primary objectives of this study was to determine if selenium concentrations in the environment and in avian tissues (including eggs) are high enough to cause reproductive impairment in migratory and resident birds.

Selenium concentrations in biological samples collected from the Salton Sea area during 1988-90 are summarized in table 8. Although selenium was found at all trophic levels, concentrations tended to increase with increasing trophic level, which indicates that biomagnification is occurring. This magnification is due to the increased energy needs and inefficiency of energy transfer from one trophic level to the next higher level, which can result in an imbalance between contaminant intake and elimination. Recent studies on fish (Lemly and Smith, 1987) show that biomagnification of selenium occurs in aquatic food chains, although results at intermediate trophic levels are inconsistent (Lemly, 1990). The most consistent evidence for biomagnification is at higher trophic levels (fish-eating birds and predatory fish, for example), especially when concentrations of waterborne selenium are elevated (Ogle and others, 1988).

The general trend of higher selenium concentrations in biota from the Salton Sea in comparison with concentrations from freshwater sites is similar to the trend found in bottom-sediment samples (Setmire and others, 1990). As reported by Eisler (1985), this trend also might be accounted for, in part, by the fact that selenium concentrations commonly are higher in estuarine and marine organisms than in freshwater organisms. Finally, sparse sampling in areas not significantly affected by agricultural drainwater, such as San Felipe and Salt Creeks, indicated the presence of local geological sources of selenium that might account for bioaccumulation in plants and fish.

\section{AQUATIC VEGETATION}

Algae..--Of all biota sampled throughout the Salton Sea, selenium concentrations were lowest in algae (table 8). Although there were some species differences, mean concentrations in algae generally were less than "background" concentrations of $1.0 \mu \mathrm{g} / \mathrm{g}$ dry weight (Ohlendorf, 1989). Comparisons of selenium concentrations in filamentous green algae from the Salton Sea with concentrations from other locations (table 9) indicate that concentrations are higher than those of a reference site (Volta WA), comparable to those of another drainwater site (Fernley WMA), and much lower than those of a highly contaminated drainwater site (Kesterson NWR).

Emergent vascular plants.--Cattail is the only vascular plant that was sampled during this study. Selenium concentrations in cattails from three agricultural drains were less than reporting limits. However, selenium was detected at a low concentration $(1.1 \mu \mathrm{g} / \mathrm{g}$ dry weight) in cattails from one of two creeks not significantly affected by drainwater (table 8). Comparisons of Salton Sea data with data from other areas (table 9) indicate that selenium concentrations in cattail from these two creeks are at or less than the $1 \mu \mathrm{g} / \mathrm{g}$ dry weight level normally found in aquatic plants (Ohlendorf, 1989), and well below Kesterson NWR values.

\section{AQUATIC INVERTEBRATES}

Saltwater Invertebrates.--Invertebrates collected from the Salton Sea had selenium concentrations that ranged from 0.8 to $12.1 \mu \mathrm{g} / \mathrm{g}$ dry weight (table 8 ). The only invertebrates in the Salton Sea that exceeded the critical dietary threshold selenium concentration of $5 \mu \mathrm{g} / \mathrm{g}$ dry weight for food-chain organisms ( Skorupa and Ohlendorf, 1991) were pileworms. The relatively high concentrations in pileworms can be attributed to the high selenium concentrations in sediment, in which the pileworms reside. Selenium concentrations in sediment are more than 3,000 times greater than concentrations in the water column, which is the habitat for pelagic invertebrates.

Selenium concentrations in waterboatman (table 9) were lower for the Salton Sea in comparison with another drainwater-affected area (Fernley WMA), much lower in comparison with a heavily affected area (Kesterson NWR), but slightly higher in comparison with a reference area (Volta WA). However, selenium concentration in all waterboatman samples 
Table 8. Selenium concentration in biota, Salton Sea area, 1988-90

[Concentrations in micrograms per gram, dry weight; <, less than indicated reporting limit; --, no data; $\mathrm{N}$, number of samples collected; DV, number of samples with detectable values; GM, geometric mean (calculated using one-half detection limit when data set has more than 50 percent detectable values)]

\begin{tabular}{|c|c|c|c|c|c|c|c|c|c|}
\hline \multirow{2}{*}{ Sample type } & \multicolumn{3}{|c|}{ Salton Sea } & \multicolumn{3}{|c|}{$\begin{array}{l}\text { New and Alamo Rivers } \\
\text { and irrigation drains }\end{array}$} & \multicolumn{3}{|c|}{$\begin{array}{l}\text { San Felipe and } \\
\text { Salt Creeks }\end{array}$} \\
\hline & N/DV & GM & Range & N/DV & GM & $\overline{\text { Range }}$ & N/DV & GM & Range \\
\hline \multicolumn{10}{|c|}{ Aquatic Vegetation } \\
\hline Blue-green algae & $1 / 1$ & -- & 1.8 & -- & -- & -- & -- & -- & -- \\
\hline Filamentous green algae & $12 / 10$ & 0.9 & $<0.58-1.7$ & -- & -- & -. & -- & -- & -- \\
\hline Tubular green algae & $13 / 8$ & .7 & $0.56-1.4$ & -- & -- & -- & -- & -- & -- \\
\hline \multicolumn{10}{|c|}{ Emergent Vegetation } \\
\hline Cattail & -- & -- & -- & $3 / 0$ & -- & $<0.64$ & $2 / 1$ & -- & $0.62-1.1$ \\
\hline \multicolumn{10}{|c|}{ Invertebrates } \\
\hline $\begin{array}{l}\text { Amphipod, pileworm, } \\
\text { waterboatman composite }\end{array}$ & $2 / 2$ & 2.8 & $2.6-3.1$ & -- & -- & -- & -- & -- & -- \\
\hline Asiatic river clam & - & - & - & $5 / 5$ & 4.4 & $2.6-6.4$ & -- & -- & -- \\
\hline Crayfish & -- & -- & -- & $2 / 2$ & 3.1 & $2.4-3.3$ & -- & -- & -- \\
\hline Pileworm & $8 / 8$ & 3.1 & $0.8-12.1$ & -- & -- & -- & -- & -- & -- \\
\hline Waterboatman & $3 / 3$ & 2.1 & $1.4-3.3$ & -- & -- & -- & -- & -- & -- \\
\hline \multicolumn{10}{|c|}{ Fish } \\
\hline Bairdiella & $5 / 5$ & 12.9 & $12.0-16.0$ & -- & -- & -- & -- & -- & -- \\
\hline Longjaw mudsucker & $1 / 1$ & -- & 6.1 & -- & -- & -- & -- & -- & -- \\
\hline Mosquitofish & -- & -- & -- & $3 / 3$ & 3.5 & $2.6-4.7$ & $2 / 2$ & 6.9 & $6.4-7.4$ \\
\hline Sailfin molly & -- & -- & -- & $4 / 4$ & 3.9 & $2.5-5.8$ & $2 / 2$ & 6.4 & $5.5-7.4$ \\
\hline \multicolumn{10}{|c|}{ Amphibians and Reptiles } \\
\hline Bullfrog & -- & -- & -- & $2 / 2$ & 4.4 & $3.6-5.4$ & -- & -- & -- \\
\hline Spiny softshell turtle (liver) & -- & -- & -- & $6 / 6$ & 10.3 & $8.0-14.0$ & -- & -- & -- \\
\hline \multicolumn{10}{|c|}{ Migratory Birds } \\
\hline Eared grebe (liver) & $5 / 5$ & 12.7 & $2.7-35.1$ & -- & -- & -- & -- & -- & -- \\
\hline Northern shoveler & & & & & & & & & \\
\hline (liver) & -- & -- & -- & $19 / 19$ & 19.1 & $9.1-47.0$ & -- & -- & -- \\
\hline (muscle) & -- & -- & -- & $6 / 6$ & 5.2 & $3.8-12.0$ & -- & -- & -- \\
\hline \multicolumn{10}{|l|}{ Ruddy duck } \\
\hline (liver) & $57 / 57$ & 11.7 & $5.2-41.5$ & -- & -- & -- & -- & -- & -- \\
\hline (muscle) & $17 / 17$ & 4.8 & $2.7-7.2$ & -- & -- & -- & -- & -- & -- \\
\hline \multicolumn{10}{|l|}{ White-faced ibis } \\
\hline (carcass) & -- & -- & -- & 9/9 & 5.3 & $3.9-6.6$ & -- & -- & -- \\
\hline (liver) & -- & -- & -- & $9 / 9$ & 7.4 & $5-13.2$ & -- & -- & -- \\
\hline \multicolumn{10}{|c|}{ Resident Birds } \\
\hline American coot (liver) & -- & -- & -- & $3 / 3$ & 10.3 & $7.9-16.3$ & -- & -- & -- \\
\hline Black-necked stilt & & & & & & & & & \\
\hline (egg) & $127 / 127$ & 4.3 & $1.6-35.0$ & -- & -- & -- & -- & -- & -- \\
\hline (carcass) & $19 / 19$ & 5.4 & $3.2-11.3$ & -- & -- & -- & -- & -- & -- \\
\hline \multicolumn{10}{|c|}{ Endangered Birds } \\
\hline $\begin{array}{l}\text { Yuma clapper rail } \\
\text { (whole body) }\end{array}$ & -- & -- & -- & $1 / 1$ & -- & 4.8 & -- & -- & -- \\
\hline
\end{tabular}


Table 9. Selenium concentration in biota from the Salton Sea area and other locations

[Concentrations are geometric means and range (in parentheses), in micrograms per gram, dry weight. Values for Kesterson National Wildlife Refuge (NWR) and Volta Wildlife Area (WA) are from Schuler (1987). Values for Fernley Wildlife Management Area (WMA) are from Hoffman, R.J., and others (1990). Values for Grasslands Water District (WD) are from Ohlendorf and others (1987). Salton Sea values are from Setmire and others (1990) or from this detailed study. ND, not detected; --, not determined]

\begin{tabular}{|c|c|c|c|c|c|c|c|c|}
\hline \multirow[b]{2}{*}{ Sample type } & \multicolumn{4}{|c|}{ Salton Sea area } & \multirow[b]{2}{*}{$\begin{array}{l}\text { Kesterson } \\
\text { (NWR) }\end{array}$} & \multirow[b]{2}{*}{$\begin{array}{l}\text { Grasslands } \\
\text { (WD) }\end{array}$} & \multirow[b]{2}{*}{$\begin{array}{l}\text { Fernley } \\
\text { (WMA) }\end{array}$} & \multirow[b]{2}{*}{$\begin{array}{l}\text { Volta } \\
\text { (WA) }\end{array}$} \\
\hline & $\begin{array}{l}\text { Salton } \\
\text { Sea }\end{array}$ & $\begin{array}{l}\text { Major } \\
\text { drains }\end{array}$ & $\begin{array}{l}\text { Minor } \\
\text { drains }\end{array}$ & $\begin{array}{l}\text { San Felipe and } \\
\text { Salt Creeks }\end{array}$ & & & & \\
\hline \multicolumn{9}{|c|}{ Aquatic Vegetation } \\
\hline Filamentous green algae & $\begin{array}{c}0.9 \\
\text { (ND-1.7) }\end{array}$ & -- & -- & -- & $\begin{array}{c}30.9 \\
(14-120)\end{array}$ & -- & $\begin{array}{c}1.4 \\
\text { (ND-2.2) }\end{array}$ & $\begin{array}{c}0.3 \\
\text { (ND-0.5) }\end{array}$ \\
\hline \multicolumn{9}{|c|}{ Emergent Vegetation } \\
\hline Cattail & -- & ND & -- & (ND-1.1) & $\begin{array}{c}37.2 \\
(17-160)\end{array}$ & -- & ND & $\begin{array}{c}0.6 \\
(\mathrm{ND}-1.2)\end{array}$ \\
\hline \multicolumn{9}{|c|}{ Invertebrates } \\
\hline Waterboatman & $\begin{array}{c}2.1 \\
(1.4-3.3)\end{array}$ & -- & -- & -- & $\begin{array}{c}18.6 \\
(5.9-130)\end{array}$ & -- & $\begin{array}{c}4.1 \\
(3.5-4.7)\end{array}$ & $\begin{array}{c}1.6 \\
(1.1-1.9)\end{array}$ \\
\hline \multicolumn{9}{|c|}{ Fish } \\
\hline Mosquitofish & -- & $\begin{array}{c}10.8 \\
(7.3-16)\end{array}$ & $\begin{array}{c}3.5 \\
(2.6-4.7)\end{array}$ & $\begin{array}{c}6.9 \\
(6.4-7.4)\end{array}$ & $\begin{array}{c}226 \\
(90-430)\end{array}$ & $\begin{array}{c}7.0 \\
(5.4-8.6)\end{array}$ & $\begin{array}{c}4.2 \\
(3.9-4.4)\end{array}$ & $\begin{array}{c}1.9 \\
(1.2-3.0)\end{array}$ \\
\hline \multicolumn{9}{|c|}{ Resident Birds } \\
\hline $\begin{array}{l}\text { American coot } \\
\text { (liver) }\end{array}$ & $\begin{array}{c}12.3 \\
(7.9-21)\end{array}$ & -- & -- & -- & $\begin{array}{c}81.5 \\
(19-160)\end{array}$ & $\begin{array}{c}11.9 \\
(7.0-28)\end{array}$ & -- & $\begin{array}{c}5.4 \\
(1.8-14)\end{array}$ \\
\hline $\begin{array}{l}\text { Black-necked stilt } \\
\quad \text { (egg) }\end{array}$ & $\begin{array}{c}4.3 \\
(1.6-35)\end{array}$ & $\begin{array}{l}-- \\
--\end{array}$ & $\begin{array}{l}-- \\
--\end{array}$ & $\begin{array}{l}-- \\
--\end{array}$ & $\begin{array}{c}24.8 \\
(5.2-64)\end{array}$ & $\begin{array}{c}4.7 \\
(3.8-5.7)\end{array}$ & -- & $\begin{array}{c}2.4 \\
(1.6-3.4)\end{array}$ \\
\hline (liver) & $\begin{array}{c}21.7 \\
(19-27)\end{array}$ & -- & -- & -- & $\begin{array}{c}46.4 \\
(19-80)\end{array}$ & $\begin{array}{c}12.7 \\
(4.3-41)\end{array}$ & -- & $\begin{array}{c}7.8 \\
(6.3-9.9)\end{array}$ \\
\hline
\end{tabular}

was below the $5 \mu \mathrm{g} / \mathrm{g}$ dry weight critical dietary threshold given by Skorupa and Ohlendorf (1991).

Freshwater Invertebrates.--Mean selenium concentrations in crayfish and Asiatic river clams (table 8) were close to background values (about 4 $\mu \mathrm{g} / \mathrm{g}$ dry weight) generally detected in freshwater invertebrates (Ohlendorf, 1989). Asiatic river clams collected from five different drains had a mean selenium concentration of $4.4 \mu \mathrm{g} / \mathrm{g}$ dry weight and a range of 2.6 to $6.4 \mu \mathrm{g} / \mathrm{g}$ dry weight. Winger and others (1984) documented selenium bioaccumulation in Asiatic river clams from the Apalachicola River in Florida. The concentration of $0.7 \mu \mathrm{g} / \mathrm{g}$ wet weight reported by Winger and others (1984) is comparable to concentrations of 0.8 and $0.6 \mu \mathrm{g} / \mathrm{g}$ wet weight at
Wister and Johnson Drains, which had the lowest values from the Salton Sea area. Asiatic river clams in the Trifolium Drain and New River had the highest concentrations ( 6.3 and $6.4 \mu \mathrm{g} / \mathrm{g}$ dry weight). These clams from habitats affected by significant inflow of drainwater had selenium concentrations greater than the $4 \mu \mathrm{g} / \mathrm{g}$ concentration that is typical for freshwater invertebrates (Ohlendorf, 1989). Thus, Asiatic river clams seem to bioaccumulate selenium in relative proportion to drainwater influence.

Results of in situ selenium bioaccumulation obtained from the bioassay of transplanted Asiatic river clams are shown in figure 31 . During the first 4 months, transplanted clams in the Trifolium Drain bioaccumulated selenium to 40 percent more than 


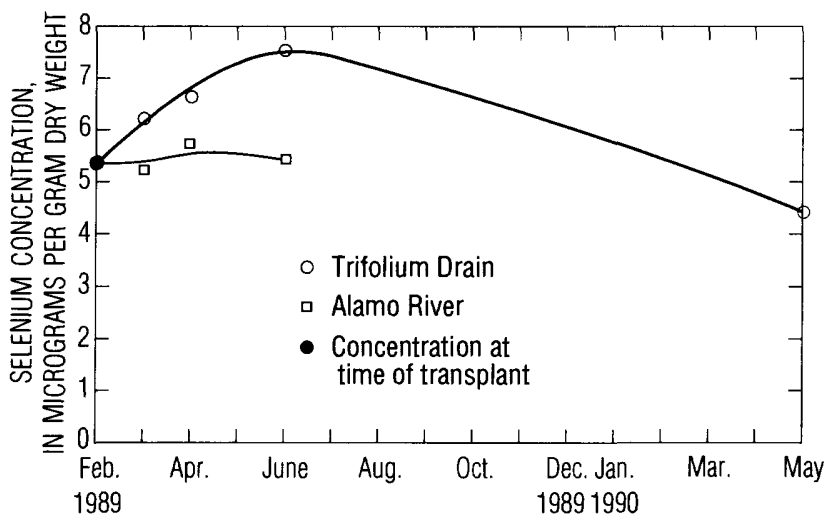

Figure 31. Bioaccumulation of selenium in transplanted Asiatic river clams, 1989-90.

beginning concentrations. This initial selenium bioaccumulation rate of about $0.5 \mu \mathrm{g} / \mathrm{g}$ dry weight per month coincided with peak spring agricultural activities in the Imperial Valley and thus with increased drainwater inflow. Clams collected 11 months later, in May 1990, indicated a slight decrease from initial concentrations and a substantial decrease from peak concentrations. Data from indigenous Asiatic river clams taken from the Trifolium Drain at the time of the bioassay had a selenium concentration of $6.3 \mu \mathrm{g} / \mathrm{g}$ dry weight. This concentration is between the highest (7.5 $\mu \mathrm{g} / \mathrm{g}$ dry weight) and lowest $(4.4 \mu \mathrm{g} / \mathrm{g}$ dry weight) concentrations in bioassay clams. Clams from the bioassay in the Alamo River (fig. 31) showed relatively little change in selenium concentration during the first 4 months.

\section{FISH}

Selenium concentrations in fish from seven sites in the Imperial Valley are given in table 8. Saltwater fish from the Salton Sea had significantly higher selenium concentrations than freshwater fish from irrigation drains. However, mosquitofish and sailfin mollies from San Felipe and Salt Creeks, which are not significantly affected by irrigation drainwater, had higher concentrations of selenium than did fish from Young, Wister, and Johnson Drains, which have moderate inflows of irrigation drainwater. High selenium concentrations in freshwater fish from San Felipe Creek, and from Trifolium Drain and the New and Alamo Rivers, were correlated with elevated selenium concentrations in water samples (Setmire and others, 1990).

A comparison with other locations (table 9) indicates that selenium concentrations in mosquitofish from the Imperial Valley were well below concen- trations in fish from Kesterson NWR, but above concentrations in fish from Volta WA (unaffected by drainwater). Selenium concentrations in fish from minor Salton Sea drains were comparable to concentrations in fish from Fernley WMA. Mosquitofish from Trifolium Drain, which receives major inflows of agricultural drainwater, had the highest concentration of selenium, $16 \mu \mathrm{g} / \mathrm{g}$ dry weight (Setmire and others, 1990).

Excessive accumulation of selenium can seriously affect fish populations of the Salton Sea (Saiki, 1990). For sensitive species, whole-body selenium concentrations greater than $12 \mu \mathrm{g} / \mathrm{g}$ dry weight may be sufficiently elevated to cause reproductive failure and deformities in embryos and young (Lemly and Smith, 1987). One sample of a freshwater species, a mosquitofish collected from the Trifolium Drain, was 30 percent above this threshold.

Saltwater fish from the Salton Sea had whole-body selenium concentrations greater than the $12 \mu \mathrm{g} / \mathrm{g}$ dry weight reproductive threshold for sensitive species reported by Lemly and Smith (1987). However, the toxic threshold concentrations for selenium in tissues of saltwater fish-such as bairdiella, orangemouth corvina, and sargo-found in the Salton Sea are unknown (White and others, 1987).

Even though Salton Sea fish continue to reproduce, recent data indicate significant decreases in the numbers of eggs and larvae of two important forage fish, bairdiella and sargo (Matsui, 1989). In addition to this reproductive decline, Matsui also documented deformities, predominantly retarded cephalic development in ichthyoplankton, that were attributed to ambient contamination. Such malformations have been reported previously following exposure of fish to a variety of anthropogenic contaminants, including pesticides and metals (Matsui, 1989). Selenium is known to cause deformities in fish (Lemly and Smith, 1987), and the concentration in Salton Sea bairdiella may be partially or fully responsible for the observed deformities.

\section{AMPHIBIANS AND REPTILES}

Selenium concentrations in two species of herpetofauna collected from the New River and several drains are given in table 8. Concentrations in whole bullfrogs from the Imperial Valley of 3.6 to $5.4 \mu \mathrm{g} / \mathrm{g}$ dry weight were within the dietary threshold of 4 to $8 \mu \mathrm{g} / \mathrm{g}$ dry weight shown to have caused reproductive impairment in waterfowl (Heinz and others, 1989). 
Aquatic birds such as herons and egrets feeding on bullfrogs in the Imperial Valley may bioaccumulate enough selenium to cause reproductive impairment.

Livers of spiny softshell turtles collected in several drains had selenium concentrations that ranged from 8.0 to $14.0 \mu \mathrm{g} / \mathrm{g}$ dry weight. Because adult turtles are not normally consumed by predators, they may serve as an indicator of selenium contamination. No comparable data were found in the literature; however, Wells and others (1988) presented selenium data for whole-body softshell turtles from an uncontaminated site in Texas. These values, ranging from less than 0.044 to $0.38 \mu \mathrm{g} / \mathrm{g}$ wet weight, were considerably lower than wet-weight values of 2.1 to $2.9 \mu \mathrm{g} / \mathrm{g}$ for turtle livers from this study. Although selenium is preferentially stored in the liver, these relatively high concentrations, nevertheless, indicate that selenium concentrations in turtles from the Imperial Valley are elevated.

\section{BIRDS}

Pathways and effects of selenium bioaccumulation on birds in the Imperial Valley were a major focus of this study. Selenium bioaccumulation problems were first documented at Kesterson Reservoir in the San Joaquin Valley, California, where selenium from agricultural drainwater bioaccumulated to sufficiently high levels in the food chain to cause mortality and impair reproduction of aquatic birds (Ohlendorf, 1989).

Because the liver is one of the major organs in vertebrates for detoxifying and eliminating selenium, it is the preferred tissue for selenium analysis. "Normal" selenium liver concentration for freshwater aquatic birds reported from several field studies is between 4 and $10 \mu \mathrm{g} / \mathrm{g}$ dry weight (Ohlendorf, 1989). Results from this study (table 10) show that several species in the Imperial Valley had liver concentrations above the normal value, and the mean concentration in northern shovelers $(19.3 \mu \mathrm{g} / \mathrm{g}$ dry weight for 31 samples analyzed in 1986-90) was considerably greater than the normal concentration.

However, selenium concentrations in bird livers that can be diagnostic of harm or injury are uncertain. The best information available indicates that when mean selenium concentration (in livers) in a bird population is about $30 \mu \mathrm{g} / \mathrm{g}$ or more on a dry-weight basis, heavy exposure has taken place and the potential for reproductive impairment is high (U.S. Fish and Wildlife Service, 1990c; J.P. Skorupa and others, U.S. Fish and Wildlife Service, written commun.,
1992). Even concentrations as low as $15 \mu \mathrm{g} / \mathrm{g}$ dry weight could be harmful to more sensitive resident species (Ohlendorf and others, 1987).

Geometric-mean selenium concentrations in bird livers collected in the Imperial Valley are given in table 10 . Forty percent of the species evaluated had selenium concentrations greater than the $30 \mu \mathrm{g} / \mathrm{g}$ dryweight threshold that has been associated with high biological risk (U.S. Fish and Wildlife Service, 1990c; J.P. Skorupa and others, U.S. Fish and Wildlife Service, written commun., 1992). Sixty percent of the eared grebes had selenium concentrations greater than this threshold, indicating a high risk of reproductive impairment. The resident double-crested cormorant had the highest mean concentration of 24.5 $\mu \mathrm{g} / \mathrm{g}$ dry weight, and 33 percent of the selenium concentrations in cormorants were greater than the risk threshold. The northern shoveler had the highest individual selenium concentration of $47 \mu \mathrm{g} / \mathrm{g}$, well above the $30 \mu \mathrm{g} / \mathrm{g}$ dry-weight threshold. This evaluation clearly shows that selenium is accumulating in some birds within the Imperial Valley to concentrations greater than those associated with a high risk for reproductive impairment.

Migratory birds.--Of the two waterfowl species (the northern shoveler and the ruddy duck) sampled in the Imperial Valley, the northern shoveler had the higher mean selenium concentration and higher range in liver and muscle tissue (table 8). Liver data for 19 Salton Sea area shovelers (mean concentration, $19.1 \mu \mathrm{g} / \mathrm{g}$ dry weight) were comparable to data for dabbling ducks collected from San Joaquin Valley sites contaminated by agricultural drainwater $(19.9 \mu \mathrm{g} / \mathrm{g}$ dry weight $)$ and well above the reference-area value of $8.4 \mu \mathrm{g} / \mathrm{g}$ dry weight (Presser and Ohlendorf, 1987). Comparisons with data collected in 1978 from the Imperial Valley by Koranda and others (1979) and data from this study (1988-90) show that selenium concentrations in shovelers are similar. In contrast, ruddy ducks had much higher geometric mean selenium concentrations $(39.1 \mu \mathrm{g} / \mathrm{g}$ dry weight in liver) in 1978 (Koranda and others, 1979) in comparison with this study $(11.7 \mu \mathrm{g} / \mathrm{g}$ dry weight in liver). This difference could be due to movement of birds in and out of the Salton Sea area from areas with different selenium concentrations. The selenium concentrations in 1978 were comparable to those for ruddy ducks collected at a contaminated site in the Tulare Basin (geometric mean $37.3 \mu \mathrm{g} / \mathrm{g}$ dry weight; Barnum and Gilmer, 1988). No data for an uncontaminated site were available, but the mean selenium concentrations in ruddy duck livers from the Salton Sea in 1988-90 were less than the $30 \mu \mathrm{g} / \mathrm{g}$ dry weight threshold (U.S. Fish and Wildlife Service, 
Table 10. Selenium concentration in aquatic-bird livers collected from the Imperial Valley, 1986-90

[Concentrations in micrograms per gram $(\mu \mathrm{g} / \mathrm{g})$ dry weight; --, not applicable]

\begin{tabular}{lcccc}
\hline \multicolumn{1}{c}{ Species } & $\begin{array}{c}\text { Number of } \\
\text { samples }\end{array}$ & $\begin{array}{c}\text { Geometric } \\
\text { mean }\end{array}$ & Range & $\begin{array}{c}\text { Percentage of } \\
\text { samples exceeding } \\
30 \mu \mathrm{g} / \mathrm{g}^{1}\end{array}$ \\
\hline American coot & 15 & 12.3 & $7.9-21.0$ & 0 \\
Black-necked stilt & 9 & 21.7 & $19.0-27.0$ & 0 \\
Cattle egret & 6 & 5.9 & $5.2-6.7$ & 0 \\
Double-crested cormorant & 9 & 24.5 & $18.0-42.0$ & 33 \\
Eared grebe & 5 & 12.7 & $2.7-35.1$ & 60 \\
Great blue heron & 1 & -- & 15.0 & 0 \\
Herring gull & 23 & 19.3 & 14.0 & 0 \\
Northern shoveler & 31 & 11.7 & $9.1-47.0$ & 10 \\
Ruddy duck & 57 & 7.4 & $5.2-41.5$ & 2 \\
White-faced ibis & 9 & $5.0-13.2$ & 0 \\
\hline
\end{tabular}

${ }^{1}$ Concentration associated with biological risk (U.S. Fish and Wildlife Service, 1990c; J.P. Skorupa and others, U.S.

Fish and Wildlife Service, written commun., 1992).

${ }^{2}$ Composite sample.

1990c; J.P. Skourpa and others, U.S. Fish and Wildlife Service, written commun., 1992).

Liver selenium concentrations in Salton Sea female ruddy ducks collected November 8,1988 (geometric mean $12.5 \mu \mathrm{g} / \mathrm{g}$ dry weight); December 22, 1988 (geometric mean $13.8 \mu \mathrm{g} / \mathrm{g}$ dry weight); and March 21, 1989 (geometric mean $11.4 \mu \mathrm{g} / \mathrm{g}$ dry weight), were not statistically different (one-way analysis of variance [ANOVA], $\mathrm{F}=1.470, \rho>0.2471$ ). However, if migratory birds are not sampled within approximately 1 week of arrival at the Salton Sea, it might not be possible to determine if selenium concentration is being elevated in the Salton Sea area, or if it was elevated prior to arrival. A study by Heinz and others (1990) demonstrated that mallard ducks took 7.8 days to reach 95 percent of peak concentrations after being fed an elevated-selenium diet. Ruddy ducks wintering at the Salton Sea may be coming from selenium-contaminated areas such as the Tulare Basin (Barnum and Evliss, 1991), and thus may already have elevated concentrations. Nevertheless, it is apparent that an equilibrium of selenium in ruddy ducks is quickly established while wintering at the Salton Sea and that selenium concentration is maintained in proportion to dietary intake.

The mean selenium concentration in livers of white-faced ibis collected from south Brawley in the Imperial Valley was $7.4 \mu \mathrm{g} / \mathrm{g}$ dry weight (table 8 ), which is comparable to concentrations in livers of ibis from the drainwater-contaminated Carson Lake, Nevada (10.7 and $8.6 \mu \mathrm{g} / \mathrm{g}$ dry weight for males and females, respectively; Henny and Herron, 1989).
Male birds had higher concentrations because females excrete selenium via eggs (Margat and Sell, 1979); however, selenium concentrations in ibis eggs from Carson Lake (geometric mean, 1.9 to $5.4 \mu \mathrm{g} / \mathrm{g}$ dry weight) did not have any significant effect on recruitment to the age of 7 to 10 days (Henny and Herron, 1989). Because selenium concentrations in Salton Sea ibis livers were lower than concentrations recorded at Carson Lake, contaminant loads accumulated while overwintering at the Salton Sea likely will not cause adverse reproductive effects at distant breeding grounds.

Eared grebe livers from the Salton Sea had the second highest mean selenium concentration in biota of $12.7 \mu \mathrm{g} / \mathrm{g}$ dry weight and concentrations as high as $35.1 \mu \mathrm{g} / \mathrm{g}$ dry weight (table 8 ). The mean concentration was twice as high as the mean concentration for grebes from uncontaminated areas in the San Joaquin Valley $(5.6 \mu \mathrm{g} / \mathrm{g}$ dry weight), but an order of magnitude below the value for grebes from highly contaminated sites (Presser and Ohlendorf, 1987). These aquatic birds feed on invertebrates and small fish, such as the mudsucker, which have lower selenium concentrations $(6.1 \mu \mathrm{g} / \mathrm{g}$ dry weight) than the larger forage fish, such as bairdiella $(12.9 \mu \mathrm{g} / \mathrm{g}$ dry weight). This probably explains why a larger fisheating bird from the Salton Sea, the double-crested cormorant, had twice as much selenium in the liver as did the eared grebe (table 10).

Resident blrds.--Selenium concentration in bird eggs is closely correlated to embryotoxicity, which is one of the most restrictive constraints for management 


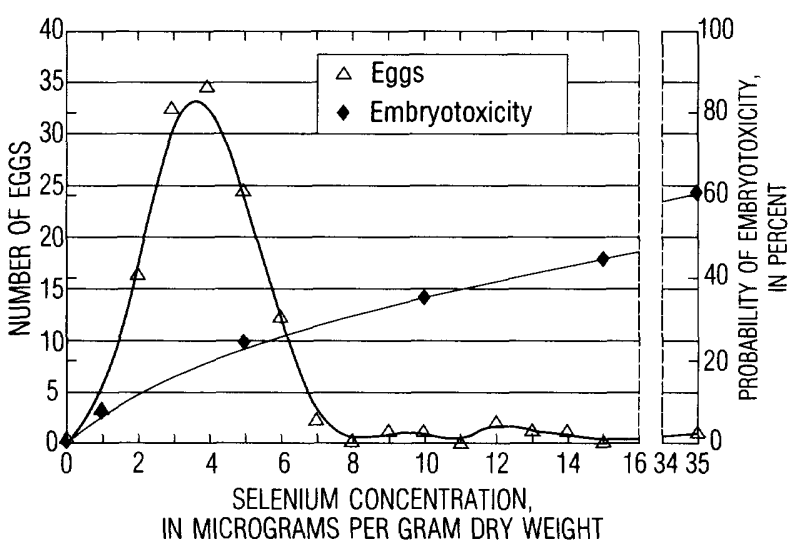

Figure 32. Concentration of selenium, and probability of embryotoxicity, in black-necked stilt eggs from the Salton Sea, 1988-89.

of agricultural drainwater (Skorupa and Ohlendorf, 1991). Selenium concentrations for two resident Salton Sea birds are given in table 8. The only nesting species extensively investigated in the Imperial Valley was the black-necked stilt.

Geometric mean concentrations of selenium in Salton Sea black-necked stilt eggs are comparable to those for Grasslands Water District; higher than Volta WA concentrations; but lower than Kesterson NWR concentrations (table 9). The geometric mean from the Salton Sea of $4.3 \mu \mathrm{g} / \mathrm{g}$ dry weight is more than double the avian background concentration of 1.9 $\mu \mathrm{g} / \mathrm{g}$ dry weight (Skorupa and Ohlendorf, 1991) and, thus, indicates contamination. The distribution of selenium in Salton Sea stilt eggs (fig. 32) shows that the probability of embryotoxicity (death or deformity) in some eggs is greater than 20 percent. For the highest selenium concentration ( $35 \mu \mathrm{g} / \mathrm{g}$ dry weight), the probability of embryotoxicity, on the basis of the relation between embryotoxicity and selenium concentration in stilt eggs at Kesterson NWR (Ohlendorf and others, 1986b), is about 60 percent. Five other stilt eggs had concentrations greater than $10 \mu \mathrm{g} / \mathrm{g}$ dry weight, the minimum concentration at which a probability of hatching failure exists (Ohlendorf and others, 1986b). Most Salton Sea stilt eggs, however, had selenium concentrations for which predicted embryotoxicity is less than 10 percent.

The expected incidence of major external deformities in embryos of uncontaminated wild bird populations is less than 1 percent when selenium in eggs is less than 3 or $4 \mu \mathrm{g} / \mathrm{g}$ dry weight (Ohlendorf and others, 1986a). The incidence of abnormalities found during 1983 for stilt nests at Kesterson Reservoir, where the mean selenium concentration in eggs was
$32.7 \mu \mathrm{g} / \mathrm{g}$ dry weight, was 16.8 percent (Ohlendorf, 1989). Data from this study indicated that 5 percent of stilt eggs from the Imperial Valley had at least a 10-percent probability of hatching failure or embryotoxicity when selenium concentration is greater than $4.3 \mu \mathrm{g} / \mathrm{g}$ dry weight.

A comparison of selenium liver concentrations in black-necked stilts from the Salton Sea (Setmire and others, 1990) with data from other locations (table 9) indicates that mean selenium concentrations at the Salton Sea are three times higher than those found at a site (Volta WA) unaffected by drainwater, and onehalf those reported at Kesterson NWR. The mean stilt liver concentration from this study $(6.7 \mu \mathrm{g} / \mathrm{g}$ wet weight) is similar to the mean concentration $(4.7 \mu \mathrm{g} / \mathrm{g}$ wet weight) for stilts collected by California Department of Fish and Game from the Salton Sea in 1986 (White and others, 1987). All Salton Sea concentrations are less than the $30 \mu \mathrm{g} / \mathrm{g}$ dry weight reproductive threshold reported by U.S. Fish and Wildlife Service (1990c) and J.P. Skorupa and others, U.S. Fish and Wildlife Service, written commun., 1992).

The mean selenium concentration of $10.3 \mu \mathrm{g} / \mathrm{g}$ dry weight in livers of coots collected in 1989 (table 8), in contrast with that in livers of stilts collected during the reconnaissance study (table 10), was not much higher than the 4 to $10 \mu \mathrm{g} / \mathrm{g}$ dry weight normal range found in freshwater aquatic birds (Ohlendorf, 1989). Selenium concentrations in coot livers collected at the Salton Sea in 1986 (Setmire and others, 1990) were slightly higher than in those collected in 1989. A comparison of coot liver selenium data (table 9) indicates that the mean concentration for the Imperial Valley is about twice as high as that for Volta WA but much lower than the concentration for coots from selenium-contaminated Kesterson NWR. Although selenium concentrations in coots are higher in the Salton Sea than in areas not affected by agricultural drainwater, the concentrations generally are within normal ranges and well below concentrations shown to cause toxicosis in wild aquatic birds (Ohlendorf and others, 1988).

Endangered birds.--The whole-body selenium concentration in a specimen of the endangered Yuma clapper rail (salvaged from the Wister WMA at the southeast part of the Salton Sea) was $4.8 \mu \mathrm{g} / \mathrm{g}$ dry weight. This is within the range for carcasses from Yuma clapper rails ( 3.3 to $5.2 \mu \mathrm{g} / \mathrm{g}$ dry weight) salvaged at the lower Colorado River (W.G. Kepner and others, U.S. Fish and Wildlife Service, written commun., 1990). Livers from lower Colorado River 
Yuma clapper rails had a mean selenium concentration of $25.3 \mu \mathrm{g} / \mathrm{g}$ dry weight (maximum concentration of $38.9 \mu \mathrm{g} / \mathrm{g}$ dry weight). These concentrations were similar to those found in water birds at Kesterson NWR, where significant reproductive failures were found (Ohlendorf, 1989).

\section{FOOD-CHAIN RELATIONS}

Selenium cycling in aquatic ecosystems has been thoroughly discussed by Lemly and Smith (1987). In the Imperial Valley, dissolved selenium contributed by sources such as irrigation drainwater first is incorporated into lower trophic levels such as plants and invertebrates (fig. 5). From there, the pathway can go directly into small forage fish and then birds, or biologically incorporated selenium can be deposited into sediment. Selenium that has accumulated in sediment then can be cycled back into biota and remain at elevated levels for years after selenium input has ceased.

The most important selenium food-chain pathway in the Salton Sea begins with accumulation by benthic invertebrates, particularly pileworms, and includes subsequent uptake by benthic-feeding fish and fisheating birds (fig. 8). Selenium is transferred from sediment through successive trophic levels in the food chain at increasing concentrations, which shows that biomagnification occurs.

Lemly and Smith (1987) generalized that lowertrophic-level consumers have concentrations of selenium that are 2 to 6 times higher than those of primary producers. This generalization is valid for the Salton Sea (fig. 33). As selenium concentration increases up the food chain, thresholds for water-bird food items (Heinz and others, 1987, 1989) are exceeded only in larger forage fish and predatory fish. Thus, the larger fish-eating birds such as brown pelicans and double-crested cormorants are at greatest risk.

In contrast to the Salton Sea, water in rivers and drains is flowing, which reduces the potential for a contaminated surface layer of sediment to develop. It is in this surface layer that bioaccumulation in plants and benthic fauna generally occurs. Selenium is introduced into these habitats as a result of comparatively (with respect to the Salton Sea) higher concentrations in water and lower concentrations in sediment. Selenium data from Setmire and others (1990) support this conclusion; the data indicate that in rivers and drains, in comparison with the Salton
Sea, selenium concentrations in sediment are lower and concentrations in water are higher.

Biological selenium pathways in rivers and drains of the Imperial Valley are depicted in figure 5 . In comparison with the selenium pathway in the Salton Sea, less bioaccumulation occurs at the highest trophic levels. Large birds feeding in rivers do not accumulate nearly as much selenium as those feeding in the Salton Sea. In rivers and drains, selenium enters the food chain through water, and accumulation from sediment is much less than in the Salton Sea. In contrast, many fish-eating birds such as doublecrested cormorants feed almost exclusively in the Salton Sea and consume fish that may have elevated selenium concentrations.

Selenium bioaccumulation in food-chain organisms of rivers and drains (fig. 34) is similar to that for Salton Sea food chains, but with lower values at similar trophic levels. Concentrations at the highest freshwater trophic level are only one-half those in the Salton Sea. For birds feeding in rivers and drains, mean selenium concentrations for all trophic levels are at or below the possible-threat-to-survival threshold (fig. 34). However, the range of concentrations for some species, especially forage fish, extends well above the area-of-concern threshold $(4 \mu \mathrm{g} / \mathrm{g}$ dry weight). Birds feeding on these freshwater fish could be exposed to concentrations that affect reproduction (greater than $7 \mu \mathrm{g} / \mathrm{g}$ dry weight) and actual long-term survival (greater than $10 \mu \mathrm{g} / \mathrm{g}$ dry weight) (Heinz and others, 1990).

\section{BORON}

In previous contaminant studies, selenium is the only inorganic drainwater constituent that has been found to be associated with abnormal development in water birds (Ohlendorf and others, 1986a; Hoffman, D.J., and others, 1988). However, recent studies by Smith and Anders (1989) and Hoffman, D.J., and others (1990) demonstrated that dietary boron concentrations well below levels that occur in the environment might have adverse reproductive effects on waterfowl. In addition, boron injected into bird eggs as either boric acid or borax causes mortality (Eisler, 1990).

Boron concentrations in biological samples collected in the Salton Sea area during 1986-90 as part of this study are summarized in table 11. Boron was found to bioaccumulate at most trophic levels; however, there was no indication of biomagnification 


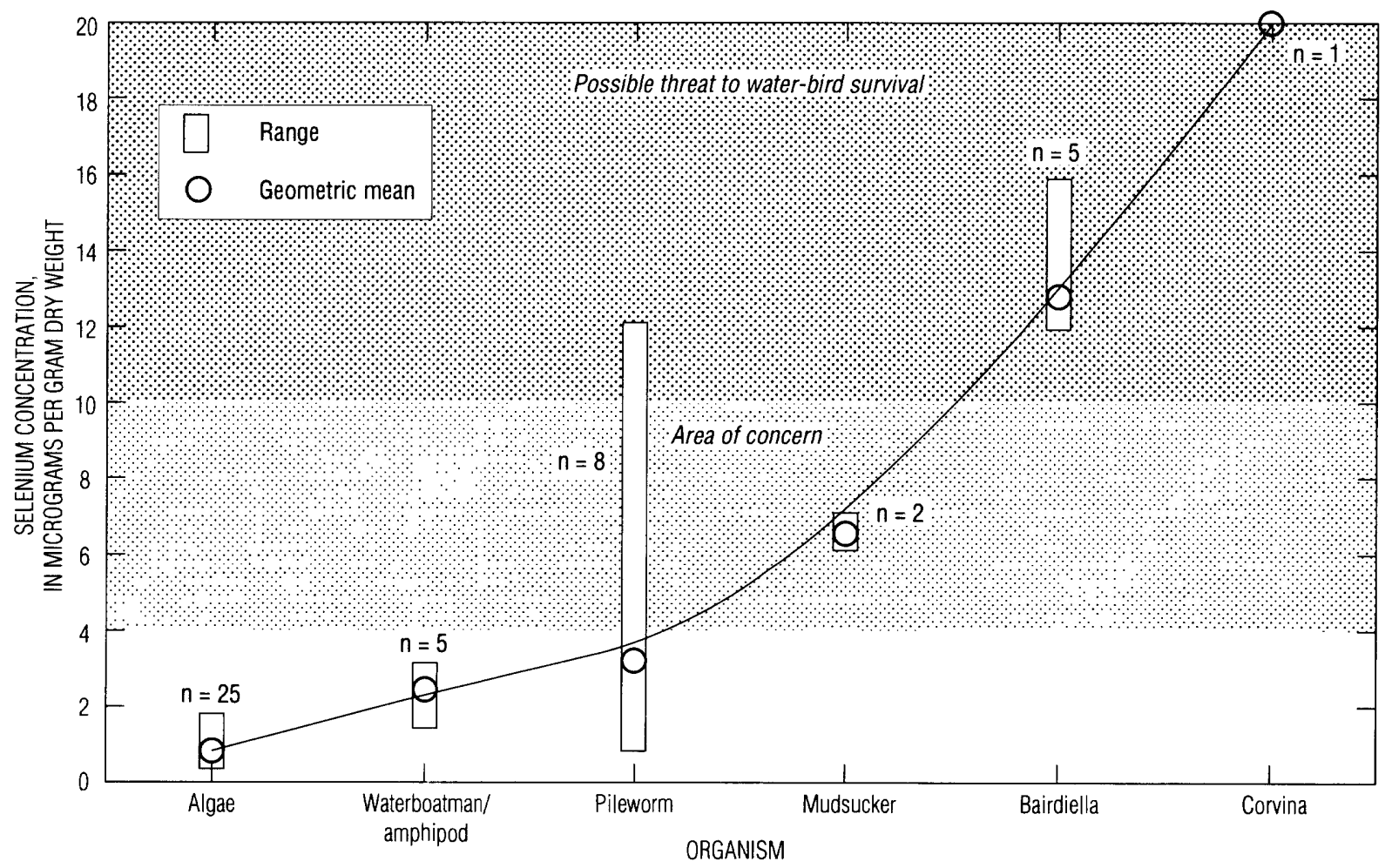

Figure 33. Concentration of selenium in food-chain organisms of the Salton Sea, 1988-90, and dietary thresholds for water birds. (Data from this study and Setmire and others, 1990). Thresholds for area of concern and possible threat to survival of water birds from Heinz and others (1987, 1989).

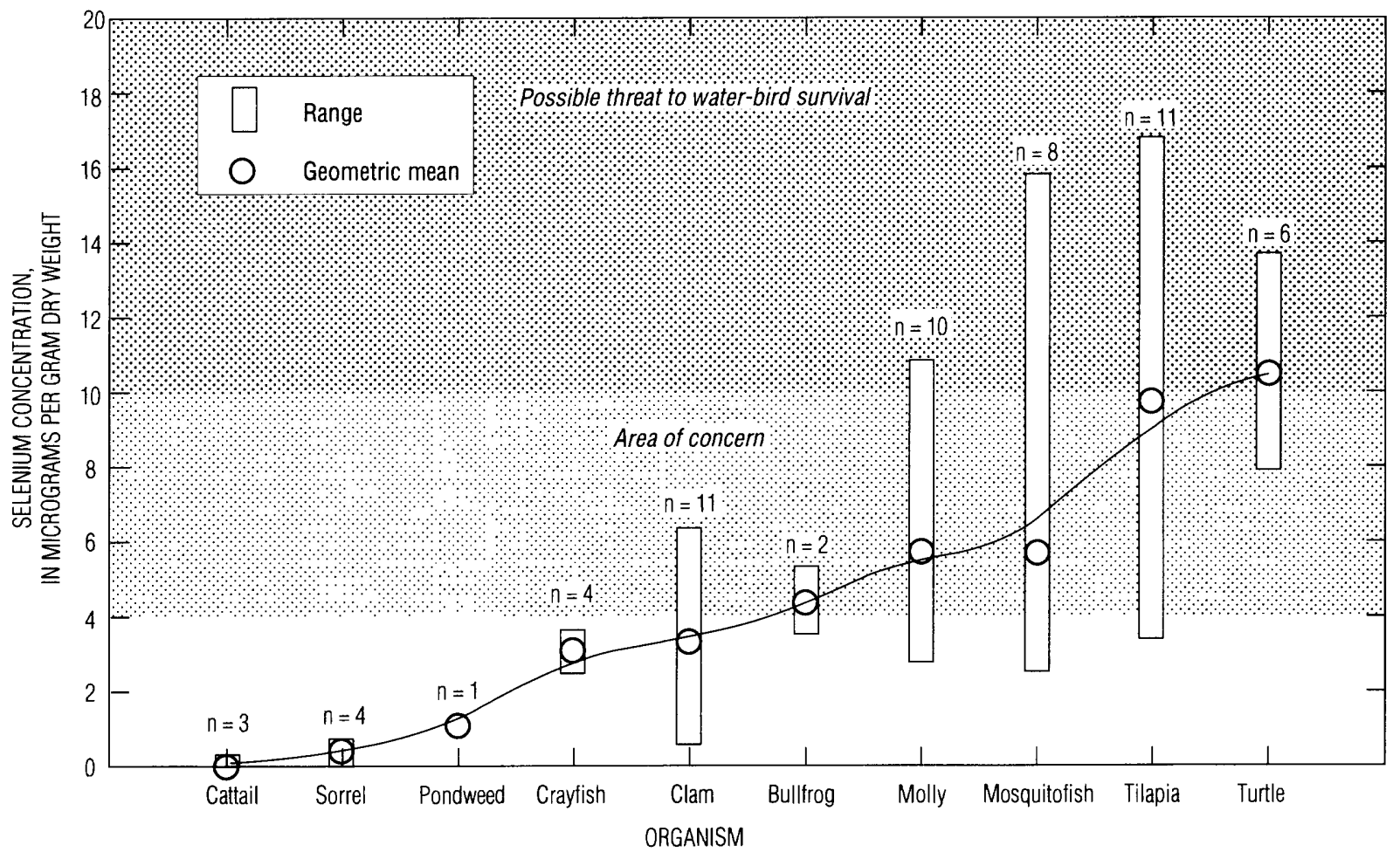

Figure 34. Concentration of selenium in food-chain organisms of rivers and drains in the Imperial Valley, 1988-90, and dietary thresholds for water birds. Thresholds for area of concern and possible threat to survival of water birds from Heinz and others $(1987,1989)$. 
Table 11. Boron concentration in biota from the Salton Sea area, 1986-90

[Concentrations in micrograms per gram, dry weight; <, less than indicated reporting limit; --, no data; $\mathrm{N}$, number of samples collected; DV, number of samples with detectable values; GM, geometric mean (non-detected values calculated using one-half detection limit when data set has more than 50 percent detectable values)]

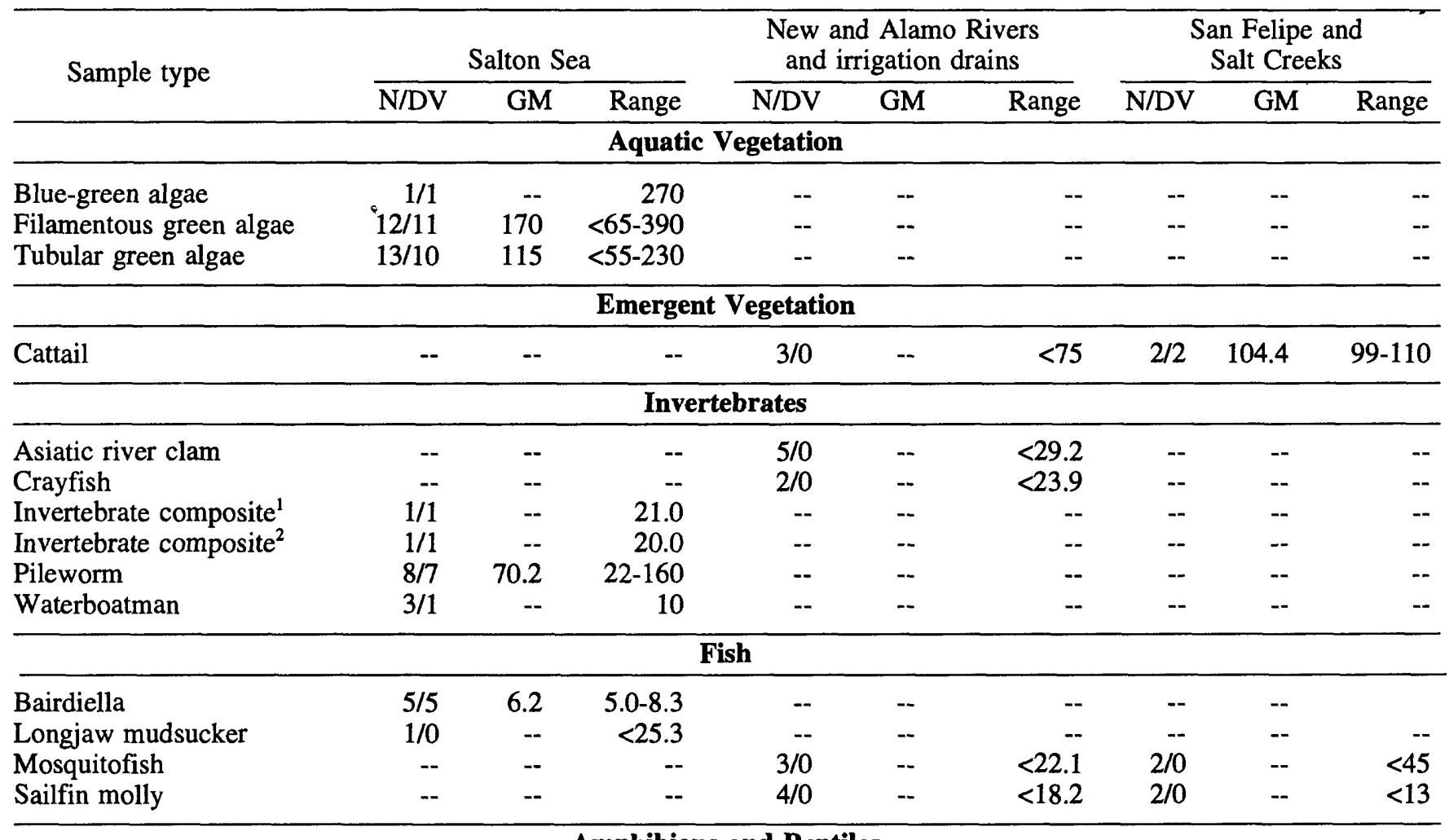

Amphibians and Reptiles

\begin{tabular}{|c|c|c|c|c|c|c|c|c|c|}
\hline $\begin{array}{l}\text { Bullfrog } \\
\text { Spiny softshell turtle }\end{array}$ & -- & -- & -- & $\begin{array}{l}2 / 2 \\
6 / 6\end{array}$ & $\begin{array}{l}3.9 \\
2.7\end{array}$ & $\begin{array}{l}3-5 \\
2-5\end{array}$ & -- & - & -- \\
\hline \multicolumn{10}{|c|}{ Migratory Birds } \\
\hline $\begin{array}{l}\text { Eared grebe } \\
\text { (liver) }\end{array}$ & \multicolumn{4}{|c|}{ Eared grebe } & -- & -- & -- & & -- \\
\hline $\begin{array}{l}\text { Northern shoveler } \\
\text { (liver) } \\
\text { (muscle) }\end{array}$ & $\begin{array}{l}-- \\
--\end{array}$ & $\begin{array}{l}-- \\
--\end{array}$ & $\begin{array}{l}-- \\
--\end{array}$ & $\begin{array}{r}19 / 18 \\
6 / 2\end{array}$ & $\begin{array}{r}3.9 \\
--\end{array}$ & $\begin{array}{l}<2-6.3 \\
<2-3.0\end{array}$ & -- & -- & -- \\
\hline \multicolumn{10}{|l|}{ Ruddy duck } \\
\hline $\begin{array}{l}\text { (liver) } \\
\text { (muscle) }\end{array}$ & $\begin{array}{r}54 / 42 \\
17 / 6\end{array}$ & $\begin{array}{r}2.7 \\
--\end{array}$ & $\begin{array}{l}<2-7.3 \\
<2-4.0\end{array}$ & -- & -- & -- & -- & -- & -- \\
\hline \multicolumn{10}{|l|}{ White-faced ibis } \\
\hline $\begin{array}{l}\text { (liver) } \\
\text { (muscle) }\end{array}$ & -- & -- & -- & $\begin{array}{l}9 / 0 \\
9 / 1\end{array}$ & -- & $\begin{array}{r}<1.7 \\
<3-3.0\end{array}$ & -- & - & -- \\
\hline \multicolumn{10}{|c|}{ Resident Birds } \\
\hline (egg) & $83 / 30$ & 1.8 & $<2-6.0$ & -- & -- & -- & -- & -- & -- \\
\hline (carcass) & $19 / 18$ & 3.0 & $<2-6.6$ & -- & -- & -- & -- & -- & -- \\
\hline
\end{tabular}

Endangered Birds

Yuma clapper rail

$\begin{array}{llll}-- & -- & -- & 1 / 1\end{array}$

- 11

14.0

\footnotetext{
${ }^{1}$ Waterboatman and amphipod.

${ }^{2}$ Waterboatman, amphipod, and pileworm.
} 
Table 12. Boron concentration in filamentous algae and submerged aquatic vegetation from the Salton Sea area and other locations, 1988-90

[Concentrations are in micrograms per gram, dry weight. Values for Stillwater Wildlife Management Area (WMA) reconnaissance investigation (Carson Lake) and background location (Carson Valley) from Hoffman, R.J., and others (1990) and for Kesterson National Wildlife Refuge (NWR) and Volta Wildlife Area from Schuler (1987). N, number of samples analyzed; DV, number of samples with detectable values; <, less than indicated reporting limit; --, not determined]

\begin{tabular}{|c|c|c|c|c|}
\hline Sample type & Location & $\mathrm{N} / \mathrm{DV}$ & $\begin{array}{c}\text { Geometric } \\
\text { mean }\end{array}$ & Range \\
\hline \multirow[t]{5}{*}{ Filamentous algae } & $\begin{array}{l}\text { Salton Sea } \\
\text { Stillwater WMA }\end{array}$ & $12 / 11$ & 170 & $<65-390$ \\
\hline & (Carson Lake) & $13 / 13$ & 199 & $110-410$ \\
\hline & (Carson Valley) & $3 / 0$ & -- & $<81.0$ \\
\hline & Kesterson NWR & $9 / 9$ & 501 & $390-787$ \\
\hline & Volta WA & $6 / 6$ & 85 & $64-140$ \\
\hline \multirow{4}{*}{$\begin{array}{l}\text { Submerged aquatic } \\
\text { vegetation }\end{array}$} & Salton Sea area & $1 / 1$ & -- & 270 \\
\hline & Stillwater WMA & $8 / 7$ & 326 & $<5.6-1,200$ \\
\hline & Carson Lake & $8 / 8$ & 277 & $77-539$ \\
\hline & Kesterson NWR & $21 / 21$ & 371 & $120-780$ \\
\hline
\end{tabular}

through food chains. On the contrary, the data reflect biominification in both saltwater and freshwater food chains. This trend in boron bioaccumulation also is evident in data from Jenkins (1980), Schuler (1987), Schroeder and others (1988), Eisler (1990), and Lemly (1990). The pattern of boron bioaccumulation was similar to the pattern of boron concentration in water (Setmire and others, 1990); bioaccumulation generally was higher for the Salton Sea than for rivers and drains (table 11). Sparse sampling in areas not significantly affected by agricultural drainwater, such as San Felipe and Salt Creeks, indicates that local sources of boron also exist in parts of the Salton Sea Basin.

\section{AQUATIC VEGETATION}

Alga日.--Algae collected from the Salton Sea had the highest concentrations of boron in biological samples (table 11). No adverse effects on algae are known to occur at the maximum concentration, 390 $\mu \mathrm{g} / \mathrm{g}$ dry weight, detected in the Salton Sea samples. In fact, boron concentrations of $11,000 \mu \mathrm{g} / \mathrm{L}$ in water of the Salton Sea (Setmire and others, 1990) are similar to concentrations found to be stimulatory to some marine algae (Anita and Cheng, 1975). In comparison with data reported by Jenkins (1980), Salton Sea algae have boron concentrations as much as three times higher than those of marine algae from areas not affected by contamination. Boron concentrations in filamentous green algae (table 12) from the Salton Sea are similar to those found at Stillwater
WMA (Carson Lake). The Salton Sea concentrations are somewhat lower than concentrations in algae from Kesterson NWR, and higher than concentrations at reference sites of other irrigation-drainage study areas.

Submerged vascular plants.--Submerged aquatic vascular vegetation was collected from Trifolium/Vail Drains during the reconnaissance investigation (Setmire and others, 1990). The boron concentration of the Salton Sea sample, as indicated in table 12, was within the range for other submerged aquatic vegetation collected from drainwater-contaminated areas such as Kesterson NWR, Stillwater WMA, and Carson Lake but was 2.2 to 20.6 times higher than concentrations reported by Jenkins (1980) for plants of the same genus (Potomageton sp.) in uncontaminated areas. Schuler (1987) found boron concentrations in seeds of submerged aquatic vegetation to be considerably higher than whole-plant concentrations and that boron concentrations were higher in the winter months. The pondweed samples from Trifolium/Vail Drains collected in December 1986 (especially the seeds) may represent the highest level of boron encountered by wintering waterfowl feeding in rivers and drains of the Imperial Valley.

Emergent vascuiar piants.--The highest boron concentrations found outside the Salton Sea, in freshwater, were in cattails (99 to $110 \mu \mathrm{g} / \mathrm{g}$ dry weight) collected in San Felipe and Salt Creeks. These samples probably represent bioaccumulation from a source of boron unrelated to drainwater. 
These concentrations are higher than concentrations (15.0 to $30.0 \mu \mathrm{g} / \mathrm{g}$ dry weight) reported by Adams and others (1973). Soil concentrations as low as 15 $\mathrm{mg} / \mathrm{kg}$ (Maas, 1986) were reported to be toxic to agricultural plants; however, tolerances of most aquatic plants are not known.

\section{AQUATIC INVERTEBRATES}

Saltwater invertebrates. --Pileworms collected in the Salton Sea had the highest boron concentrations (as high as $160 \mu \mathrm{g} / \mathrm{g}$ dry weight) of sampled aquatic invertebrates (table 11). A composite sample of pileworms, amphipods, and waterboatmen (representing a typical water-bird diet) yielded a boron concentration of $20 \mu \mathrm{g} / \mathrm{g}$ dry weight, which is elevated in comparison with other food items analyzed, but well below the concentration in pileworms. The waterboatman/amphipod composite had a similar value of $21 \mu \mathrm{g} / \mathrm{g}$ dry weight. A Salton Sea sample of waterboatmen yielded a boron concentration of 10 $\mu \mathrm{g} / \mathrm{g}$ dry weight, which is comparable to concentrations in waterboatmen collected from a reference site (Volta WA; geometric mean 11.8, range 7.4 to 21 $\mu \mathrm{g} / \mathrm{g}$ dry weight; Schuler, 1987).

Freshwater Invertebrates.--In an effort to determine potential bioaccumulation of boron and other drainwater contaminants in invertebrates from river and drain sites, an in situ bioaccumulation test was done. Asiatic river clams that were collected from the Colorado River and transplanted in the Trifolium Drain and the Alamo River showed an initial (first month) increase in boron (fig. 35) followed by depuration (during the next 3 months). The initial increase in boron concentration in early March occurred during increased agricultural activity, which results in increased water use. As drainwater and its sediment load stabilized during the growing season, boron concentrations in the transplanted clams decreased.

According to Eisler (1990), most invertebrates can tolerate boron in the water column at concentrations as high as $10 \mathrm{mg} / \mathrm{L}$ for extended periods without adverse effects. Exposure of the zooplankton Daphnia magna to $13.6 \mathrm{mg} / \mathrm{L}$ of boron over a 21 -day period resulted in reductions in the number of broods, total young produced, mean brood size, and mean size (Lewis and Valentine, 1981; Gersich, 1984). The highest dissolved boron concentration of $11 \mathrm{mg} / \mathrm{L}$ (in the Salton Sea) reported in the Salton Sea-Imperial Valley area (Setmire and others, 1990) was below concentrations shown to cause chronic effects in invertebrates but slightly above the safe concentration of $10 \mathrm{mg} / \mathrm{L}$.

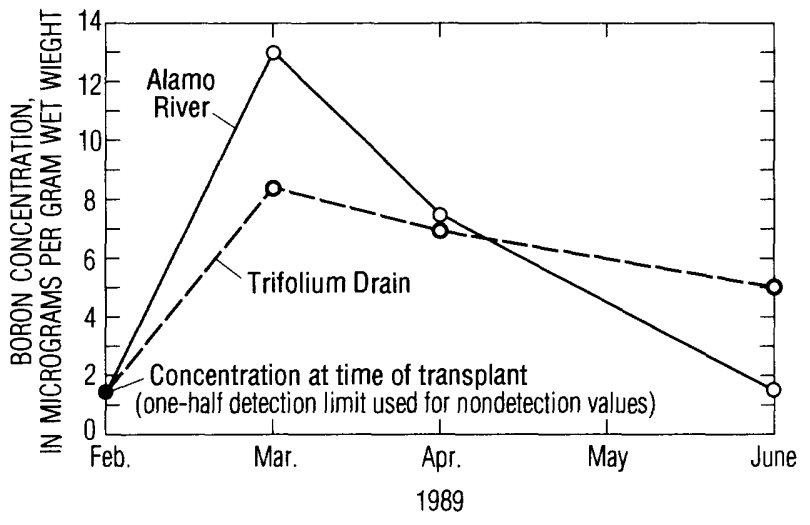

Figure 35. Bioaccumulation of boron in transplanted Asiatic river clams.

FISH

Reporting limits for boron in forage fish from rivers and drains (sailfin mollies and mosquitofish) and one estuarine species (longjaw mudsucker) were as high as $45 \mu \mathrm{g} / \mathrm{g}$ dry weight, and boron was not detected in these species. However, bioaccumulation at levels less than these reporting limits may occur. The boron concentration in mosquitofish (one composite; $25 \mu \mathrm{g} / \mathrm{g}$ dry weight) collected as part of the reconnaissance investigation in 1986 (Setmire and others, 1990) was similar to levels found at Kesterson NWR (16.9 to $25.9 \mu \mathrm{g} / \mathrm{g}$ dry weight) in 1985 (Hothem and Ohlendorf, 1989) - and elevated in comparison with concentrations detected in the Stillwater WMA reconnaissance investigation $(4.0$ to $6.3 \mu \mathrm{g} / \mathrm{g}$, dry weight; Hoffman, R.J., and others, 1990) and the San Joaquin River system (2.2 to $9.8 \mu \mathrm{g} / \mathrm{g}$ dry weight). Boron concentrations in bairdiella (geometric mean 6.2 , range 5.0 to $8.3 \mu \mathrm{g} / \mathrm{g}$ dry weight) were much less than the mean of $25.3 \mu \mathrm{g} / \mathrm{g}$ dry weight found in bairdiella collected earlier from the Salton Sea by Saiki (1990). The reason for this difference is unknown. Boron concentrations in fish collected from freshwater in river and drain sites (Setmire and others, 1990) are similar to those from the Salton Sea (Saiki, 1990; Setmire and others, 1990). Saiki (1990) found that orangemouth corvina had the lowest boron concentrations of fish from the Salton Sea. There are no known standards, criteria, or effect levels for boron in fish.

\section{AMPHIBIANS AND REPTILES}

Boron concentrations in samples of two species of herpetofauna from the river and drain sites (bullfrog and spiny softshell turtle) were low (table 11) and at 


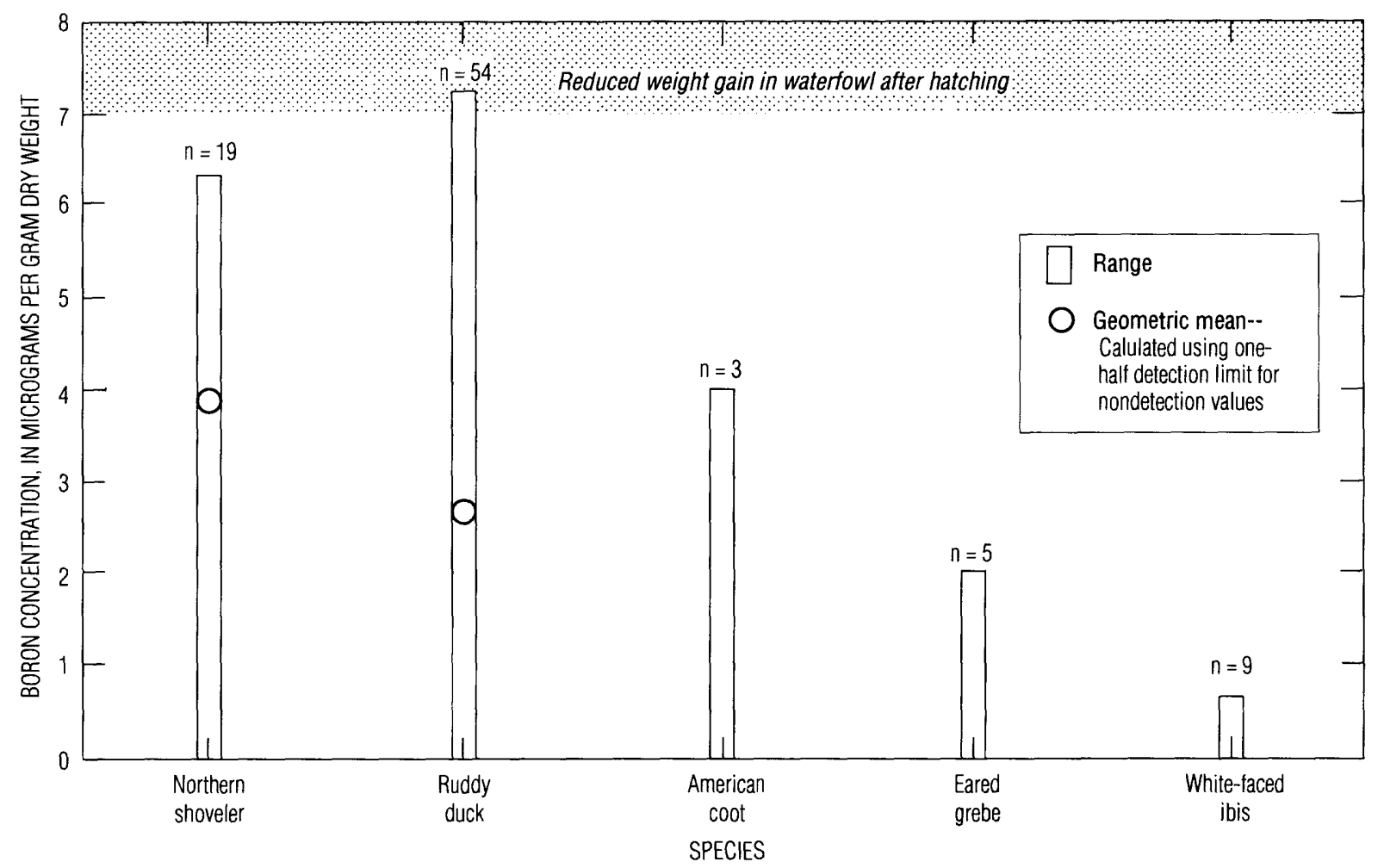

Figure 36. Concentration of boron in livers of waterfowl and water birds from the Salton Sea area, 1988-90, and threshold for reduced weight gain. Threshold for reduced weight gain from Smith and Anders (1989).

levels not known to cause adverse effects in these species (Eisler, 1990). Quantifiable concentrations of boron in prey species of frogs (waterboatman) and turtles (sailfin molly and mosquitofish; Setmire and others, 1990) were as much as five times greater than in the herpetofauna, which indicates that biominification was occurring.

BIRDS

Migratory birds.--Boron concentrations in bird livers (fig. 36) were higher in waterfowl (northern shoveler and ruddy duck) than in water birds (American coot, eared grebe, and white-faced ibis). Boron in bird muscle was low, with most samples being less than reporting limits (table 11). Birds from the Salton Sea and the mouths of rivers (saltwater and estuarine habitats) had higher levels of boron than did birds feeding in the upper river, drains, and agricultural fields (freshwater habitats). Migratory waterfowl (female ruddy ducks) were sampled in November 1988 on arrival at the Salton Sea, 1 month later, and in March 1989 just prior to departure. Boron concentrations in liver samples were nondetectable on arrival and increased to quantifiable levels on departure from the Salton Sea. A simple linear regression was used to determine if the increase in boron concentration from autumn to spring was related to bird weight. No relation between bird weight and liver boron concentration was found $\left(r^{2}=0.03, F=0.869, \mathrm{p}>0.360\right)$.

Ruddy ducks had the greatest range of boron concentrations in livers (less than 2 to $7.3 \mu \mathrm{g} / \mathrm{g}$ ), and northern shovelers sampled in winter 1988 had the highest geometric mean $(3.9 \mu \mathrm{g} / \mathrm{g})$. Ruddy ducks eat primarily pileworms, which are high in boron concentration; whereas, shovelers, in addition, feed on plants, which are much higher in boron concentration. Thus, shovelers would be expected to have higher levels of boron than do ruddy ducks. These species of waterfowl also may incidentally consume algae, which harbor significant invertebrate biomass that had the highest boron concentrations found in biological samples for this study.

Boron concentration in food items of waterfowl at the Salton Sea ranged from 10 to $390 \mu \mathrm{g} / \mathrm{g}$ dry weight (table 11). In a study by Smith and Anders (1989), reduced weight gain was noted in mallard ducklings hatched from eggs laid by females fed diets containing as little as $35 \mu \mathrm{g} / \mathrm{g}$ dry weight of boron. 


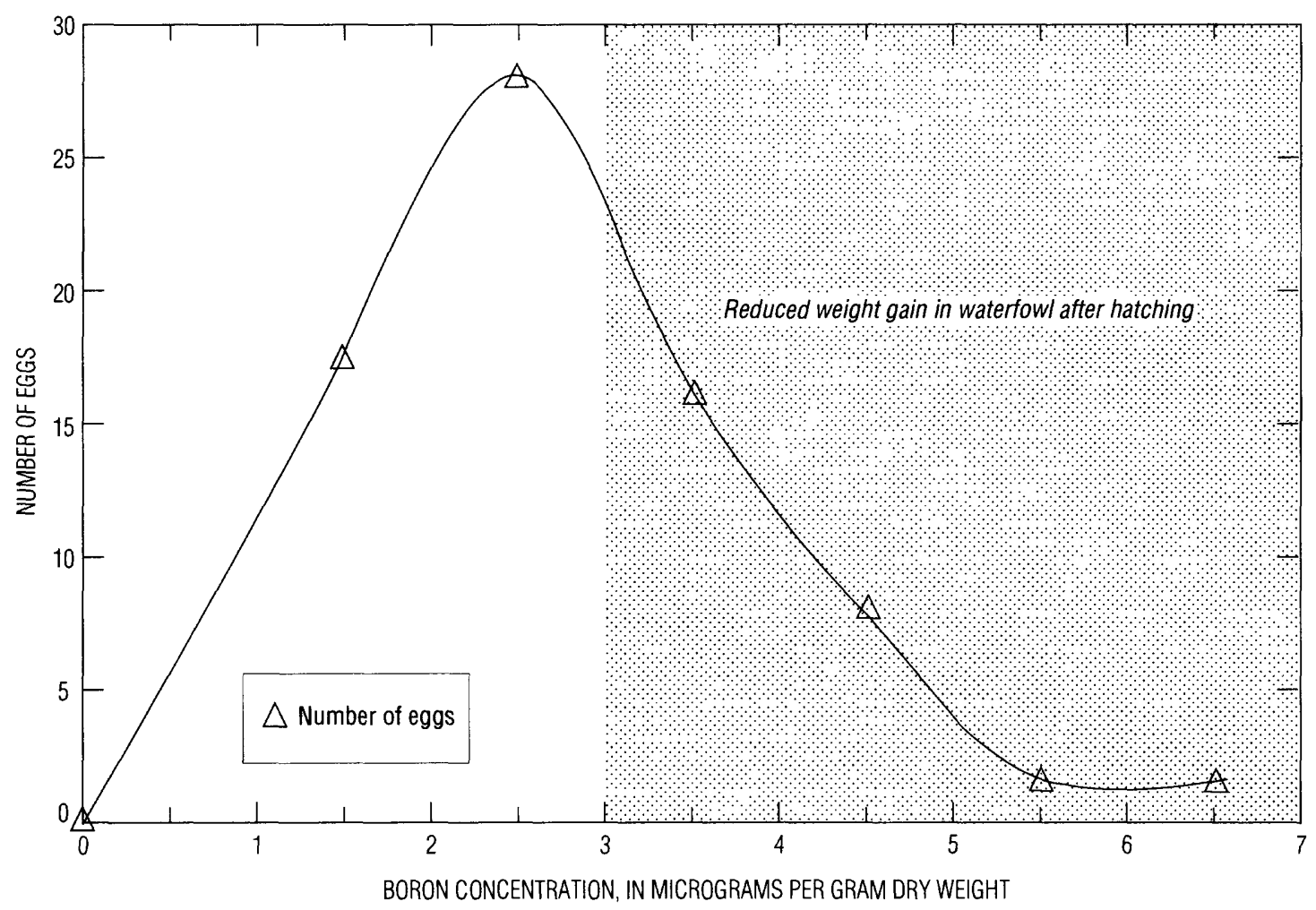

Figure 37. Concentration of boron in black-necked stilt eggs from the Salton Sea area, 1988-90, and threshold for reduced weight gain. Threshold for reduced weight gain from Smith and Anders (1989).

When females from the same study were fed a diet of $388 \mu \mathrm{g} / \mathrm{g}$ dry weight of boron, duckling body weight at hatch was significantly lower, and duckling weight gain was reduced in comparison with controls. Corresponding boron concentrations in livers of these adult mallards were less than 3 to $4 \mu \mathrm{g} / \mathrm{g}$ dry weight for birds fed $35 \mu \mathrm{g} / \mathrm{g}$ dry weight and 7 to $24 \mu \mathrm{g} / \mathrm{g}$ dry weight for birds fed $388 \mu \mathrm{g} / \mathrm{g}$ dry weight. On the basis of these laboratory data and boron concentrations in waterfowl livers from this study, waterfowl at the Salton Sea generally ingested a diet containing less than $388 \mu \mathrm{g} / \mathrm{g}$ dry weight of boron. The data indicate that growth rates of ducklings hatched from wintering waterfowl could be adversely affected. Because most waterfowl at the Salton Sea are migratory and nest elsewhere, however, it is difficult to determine if actual reductions in duckling growth rate or body weight occur as a result of bioaccumulation by adults in the Imperial Valley. As previously discussed, ruddy ducks sampled prior to departure from the Salton Sea had boron concentrations in the liver that were elevated in comparison with levels when they first arrived. When these birds return to breeding grounds, they have boron concentrations that potentially could cause sublethal adverse effects in ducklings.
Resident birds.--The black-necked stilt is the only resident nesting bird that was examined extensively. Carcass concentrations of boron were low (table 11). Stilt food items consist of waterboatmen, amphipods, and pileworms, which have boron concentrations that ranged from 10 to $160 \mu \mathrm{g} / \mathrm{g}$ dry weight (table 11 ). As discussed by Smith and Anders (1989), a diet of $35 \mu \mathrm{g} / \mathrm{g}$ dry weight of boron was found to cause a reduction in duckling weight gain. In the same study, corresponding boron concentrations in eggs of hens fed $35 \mu \mathrm{g} / \mathrm{g}$ dry weight of boron were 3 to $4 \mu \mathrm{g} / \mathrm{g}$ dry weight. Boron concentrations in stilt eggs in this study (fig. 37) were as much as twice as high as the threshold level associated with reduced duckling weight gain.

Growth rates of nestling stilts at the Salton Sea were compared with those of stilts from a site not affected by agricultural drainwater (Bolsa Chica Ecological Reserve, Orange County, California) in 1988-89 (R.A. James, U.S. Fish and Wildlife Service, written commun., 1990). A comparison was made using bird weight in relation to tarsus length and wing length, which are used to predict age, in young stilts. Schew and Collins (1990) have found wing lengths in another water bird, black skimmer, to be an accurate 


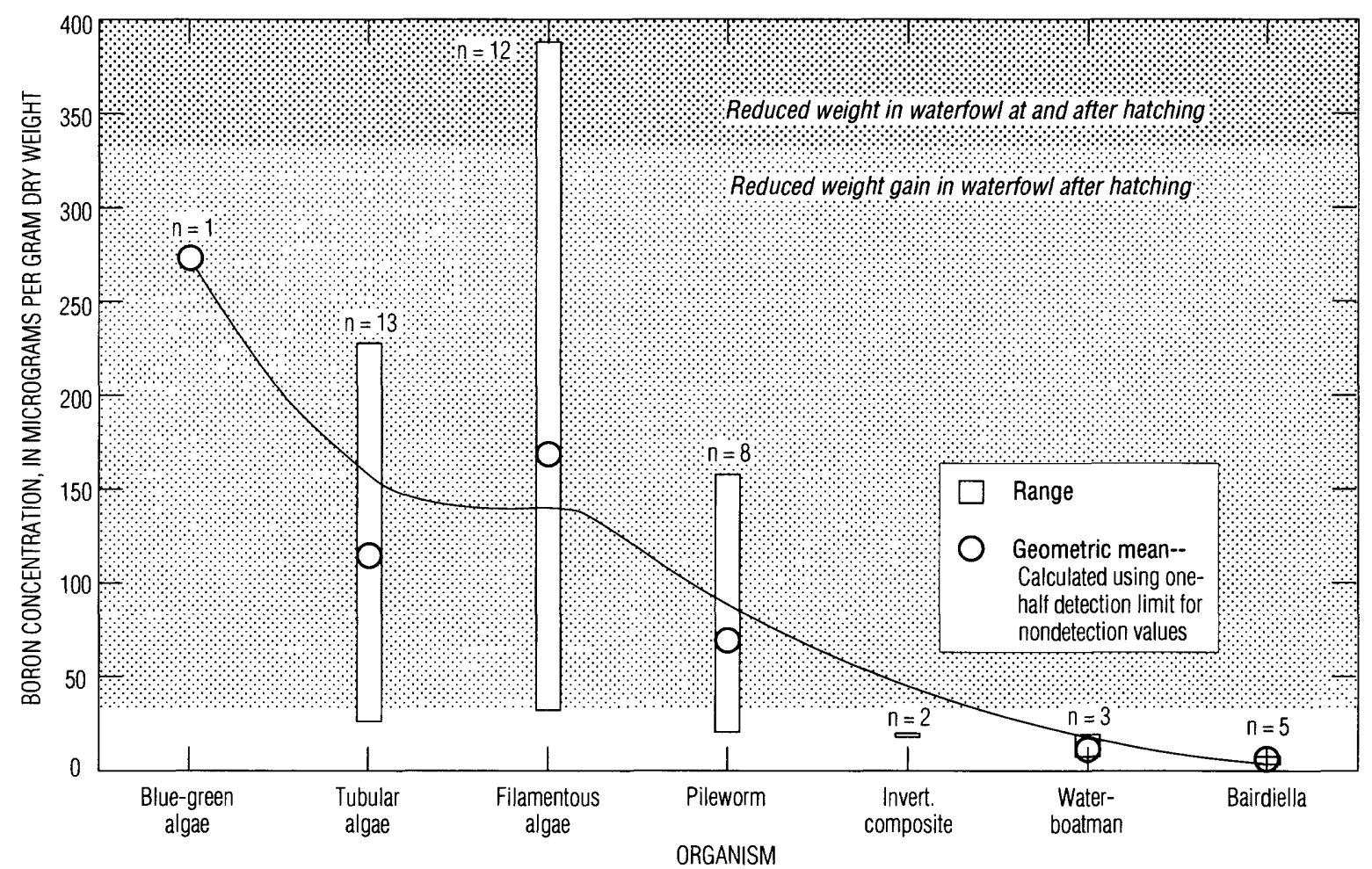

Figure 38. Concentration of boron in food-chain organisms of the Salton Sea, 1986-90, and dietary thresholds for waterfowl. Thresholds for reduced weight gain and reduced weight from Smith and Anders (1989).

and dependable indicator of chick age. Analysis of covariance was used to investigate site differences with respect to the relation between weight and tarsus and wing lengths. The slopes of log weight in relation to $\log$ tarsus were significantly different $\left(r^{2}=\right.$ $0.97, F=8.24, \mathrm{p}=0.0003$ ); therefore, the sites also were significantly different in growth rates of juvenile black-necked stilts. After adjusting for the two covariants (tarsus and wing length), one finds that black-necked stilt young from the Salton Sea apparently are significantly smaller (reduced growth rate) than young from a reference comparison site. Although boron concentrations in stilt food items and eggs are similar to levels known to cause reduced growth in young birds, other variables may be fully or partially responsible for the reduced growth rates observed at the Salton Sea. Grant (1982) extensively studied black-necked stilts at the Salton Sea and found that these birds have modified behaviors for (1) the regulation and maintenance of egg temperatures at below-lethal levels, (2) the prevention of overheating of adult birds on the nest, and (3) the regulation of nest humidity. The effects of these modifications on juvenile stilt growth are unknown.

Endangered blrds.--A Yuma clapper rail from the southeastern part of the Salton Sea at Wister WMA had a whole-body boron concentration of $14.0 \mu \mathrm{g} / \mathrm{g}$ dry weight. The only other available data for boron in Yuma clapper rails show that birds collected on the Colorado River above the Imperial Dam (Radtke and others, 1988) had concentrations less than the reporting limit (less than $5.0 \mu \mathrm{g} / \mathrm{g}$ dry weight). A light-footed clapper rail collected from Seal Beach NWR in coastal Orange County, California, had a boron concentration of $34.4 \mu \mathrm{g} / \mathrm{g}$ dry weight (U.S. Fish and Wildlife Service, 1990b). No baseline or normal levels of boron are known for clapper rails; therefore, the significance of these values is unknown.

\section{FOOD-CHAIN RELATIONS}

Boron is incorporated into the food chain from water and sediment and bioaccumulates to the highest concentrations at low trophic levels (primary producers and primary consumers). In a pattern similar to that at Kesterson NWR (Schuler, 1987) and San Joaquin Valley (Lemly, 1990), aquatic vegetation and invertebrates typically accumulated boron to concentrations higher than those found in surrounding water and sediment. Concentrations in aquatic invertebrates were lower than those in plants. Boron concentrations in food-chain organisms from the Salton Sea and river and drain sites are shown in figures 38 and 


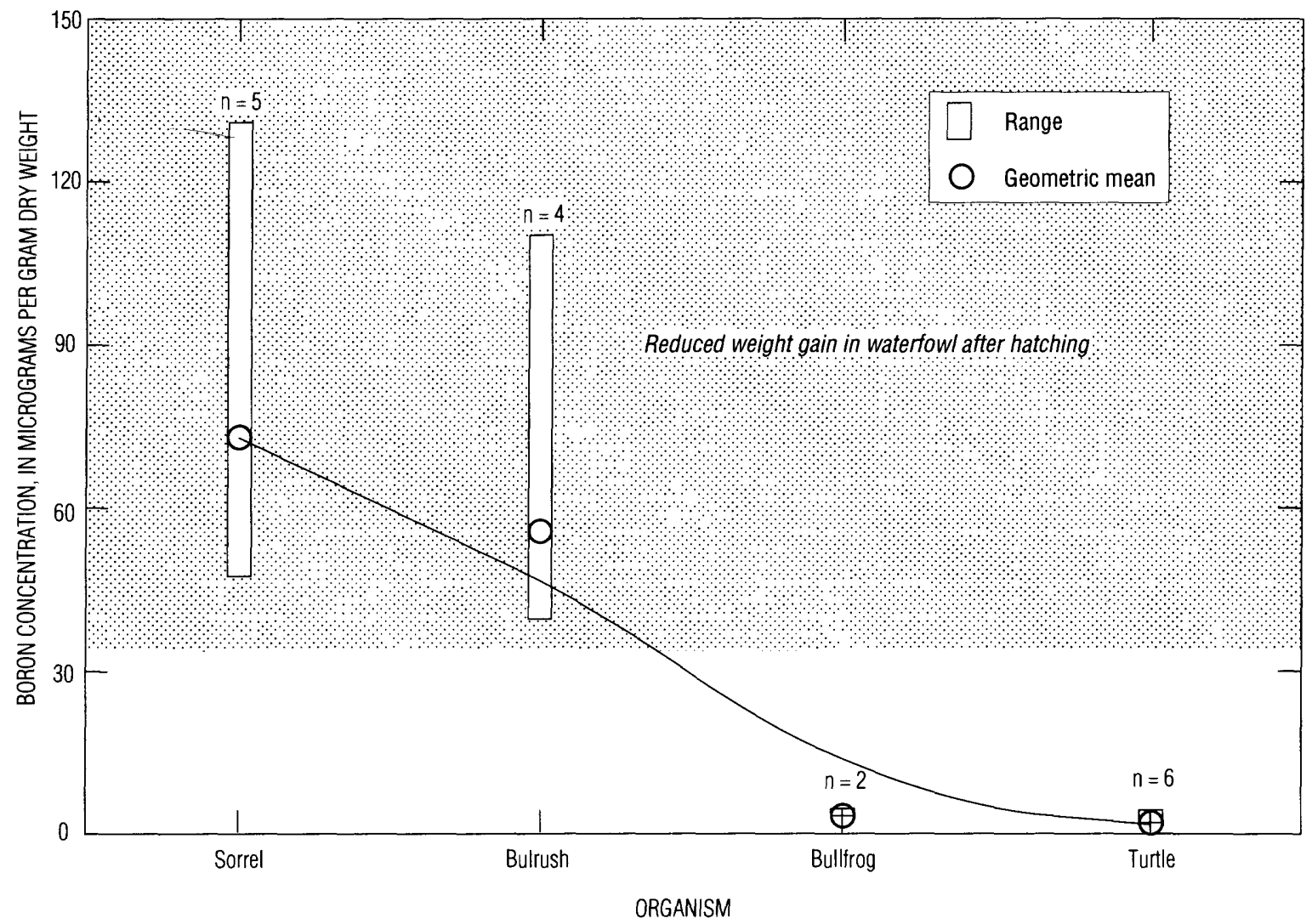

Figure 39. Concentration of boron in food-chain organisms of rivers and drains in the Imperial Valley, 1988-90, and dietary threshold for waterfowl. (Data from this study and Setmire and others, 1990). Threshold for reduced weight gain from Smith and Anders (1989).

39 , respectively, along with appropriate reproductive thresholds (from Smith and Anders, 1989). Organisms were arranged in these figures according to relative trophic levels that are similar to those of Young (1984).

Benthic invertebrates, and the birds that feed on them, had higher boron concentrations than did planktonic invertebrates and birds that consume them (table 11). Data from Klasing and Pilch (1988), Stephens and others (1988), and Wells and others (1988) show a similar trend in boron concentrations for benthic fish in comparison with pelagic fish. Also, birds, including shovelers, that feed on both vegetation and invertebrates had elevated levels of boron in comparison with birds (such as ruddy ducks) that feed mainly on invertebrates. However, at least some individuals of all higher-trophic-level consumers that feed directly on lower-trophic-level organisms bioaccumulated boron at levels known to have chronic reproductive effects on waterfowl, including reduction of weight gain in ducklings and (or) reduced hatchling weight (Smith and Anders, 1989).
Migratory waterfowl had the highest boron concentrations of all bird groups sampled because they feed on a higher proportion of vegetation that has high boron concentrations. Boron data for ruddy ducks in this study indicate that birds arrive at the Salton Sea with moderately low levels (mostly nondetectable) of boron and that some individuals depart with levels known to cause adverse reproductive effects. Although resident shorebirds, such as the black-necked stilt, generally bioaccumulated less boron than waterfowl, accumulation of boron in shorebirds may be sufficient to cause reduced weight gain in young. Fish-eating birds feeding at the Salton Sea also may be bioaccumulating boron at levels known to cause reproductive effects.

Boron is removed through respiration and (or) excretion more rapidly at progressively higher trophic levels in both saltwater and freshwater food chains of the Salton Sea system. This process of biominification, however, does not prevent potential adverse reproductive effects on waterfowl and shorebirds that feed directly on lower-trophic-level food items. especially vegetation. 


\section{ORGANOCHLORINE PESTICIDES}

Organochlorine pesticides were used, particularly during the 1940's and 1950's, to help increase food production through the control of pests (U.S. Environmental Protection Agency, 1980a). This was successfully achieved not only because of the toxicity of these pesticides but also because they were effective for a long period of time. However, because organochlorine pesticides are lipophilic and persistent, and were used extensively throughout the country, widespread bioaccumulation occurred in aquatic and terrestrial food chains (U.S. Environmental Protection Agency, 1980a). Long-lived species at the top of the food chain, such as bald eagles, accumulated body burdens that caused serious reproductive problems (U.S. Environmental Protection Agency, 1980a).

Organochlorine compounds have been extensively used in agriculture in the Imperial and Coachella Valleys. Results of a California Toxic Substances Monitoring Program (1983a) study indicate that fish from the Imperial Valley had some of the highest organochlorine body burdens in the State. Since 1978, total-DDT and toxaphene concentrations in fish in the Imperial Valley routinely have exceeded the National Academy of Sciences, National Academy of Engineering (1973) recommended levels for the protection of aquatic wildlife (total DDT, $1.0 \mathrm{mg} / \mathrm{kg}$ [1.0 $\mu \mathrm{g} / \mathrm{g}]$ wet weight; toxaphene, $0.1 \mu \mathrm{g} / \mathrm{g}$ wet weight) (California Toxic Substances Monitoring Program, 1983a, 1983b). The latest CTSMP data for 1989 show that toxaphene concentrations in fish remain above the NAS threshold level. Other organochlorine pesticides that have exceeded the NAS threshold level in the Imperial Valley are endosulfan and dieldrin (threshold for endosulfan and dieldrin is $0.1 \mathrm{mg} / \mathrm{kg}$ ).

\section{DDT AND METABOLITES}

DDT was used in the Imperial Valley as a lowcost broad-spectrum insecticide (technical DDT) and to a lesser extent as a minor component of dicofol, an acaricide used on cotton, which formerly was a major crop. DDT was banned in the United States in 1972 (in Arizona in 1969) and in Mexico in 1983. Since 1988, DDT also has been regulated in dicofol (now required to contain less than 0.1 percent DDT). Recent concentrations of $\mathrm{p}, \mathrm{p}$ '-DDE, a metabolite of DDT, found in resident fauna in the Southwestern United States (including Texas, New Mexico, Arizona, and the Salton Sea area) were at levels associated with eggshell thinning and reduced repro- ductive success in birds (Clark and Krynitsky, 1983; Fleming and Cain, 1985; White and Krynitsky, 1986; Ohlendorf and Marois, 1990). Clark and Krynitsky (1983) and White and others (1983) have suggested that recent use of DDT may have occurred in the Southwest; however, Schmitt and others $(1985,1990)$ found no evidence of such use on the basis of fish data for the region.

Most recommended environmental concentrations and action levels (National Academy of Sciences, National Academy of Engineering, 1973, for example) for DDT are based on total DDT (DDT + DDE + DDD, including p,p' and o,p' homologs); however, reproductive thresholds and biological effects have been most closely correlated with p,p'-DDE. TotalDDT concentrations are given in table 13 and p,p'DDE concentrations are given in table 14 for all biotic samples collected during both the Salton Sea reconnaissance and this detailed study. Results are similar to those for other recent studies throughout the United States: p,p'-DDE, p,p'-DDT, and p,p'-DDD were found in 99,33 , and 32 percent, respectively, of the Salton Sea samples. The o,p' homologs, which are derived from o,p'-DDT (an impurity of technicalgrade DDT), are less persistent than p,p' homologs and generally are not of concern because they normally are found only in trace amounts.

\section{Aquatic Invertebrates}

Aquatic invertebrates collected from the Salton Sea (waterboatmen and pileworms) had the lowest mean p,p'-DDE concentrations of all biotic samples (table 14). Crayfish and clams collected from freshwater rivers and drains had mean concentrations almost eight times greater than the mean concentration for Salton Sea invertebrates. DDT toxicity to invertebrates is species specific and highly variable (U.S. Environmental Protection Agency, 1980a). On the basis of laboratory toxicity testing, the aquatic invertebrate most sensitive to DDT is crayfish (U.S. Environmental Protection Agency, 1980a). The sensitivity does not allow significant bioaccumulation because of crayfish mortality at low DDT concentrations. Crayfish collected from the Imperial Valley had relatively low levels of $p, p^{\prime}-D D E$ and no detectable p,p'-DDT.

Asiatic river clams had the highest DDE concentrations of all invertebrates. Because of their immobility at the adult stage and their association with sediment, clams are an excellent bioindicator of DDE exposure. An elevated concentration (20 times 
Table 13. Total-DDT concentration in biota from the Salton Sea area, $1986-90$

[Concentrations in micrograms per gram, wet weight; --, no data; $\mathrm{N}$, number of samples collected; DV, number of samples with detectable values; GM, geometric mean (calculated using $1 / 2$ detection limit when data set has more than 50 percent detectable values)]

\begin{tabular}{|c|c|c|c|c|c|c|}
\hline \multirow{2}{*}{ Sample type } & \multicolumn{3}{|c|}{ Salton Sea } & \multicolumn{3}{|c|}{$\begin{array}{l}\text { New and Alamo Rivers } \\
\text { and irrigation drain }\end{array}$} \\
\hline & N/DV & $\mathrm{GM}$ & Range & N/DV & GM & Range \\
\hline \multicolumn{7}{|c|}{ Invertebrates } \\
\hline Asiatic river clam & -- & -- & -- & $12 / 11$ & 0.32 & $0.13-5.74$ \\
\hline Crayfish & -- & -- & -- & $4 / 4$ & .31 & $0.1-0.68$ \\
\hline Pileworm & $2 / 2$ & 0.04 & 0.03-0.04 & -- & -- & -- \\
\hline Waterboatman & $5 / 5$ & .04 & $.01-0.07$ & -- & -- & -- \\
\hline \multicolumn{7}{|c|}{ Fish } \\
\hline Bairdiella & $5 / 5$ & 0.10 & $0.08-0.12$ & -- & -- & -- \\
\hline Corvina (fillet) & $1 / 1$ & -- & 0.09 & -- & -- & -- \\
\hline Mosquitofish & -- & -- & -- & $3 / 3$ & 0.59 & $0.57-0.61$ \\
\hline Redfin shiner & -- & -- & -- & $1 / 1$ & -- & 5.82 \\
\hline Sailfin molly & -- & -. & -- & $5 / 5$ & .22 & $0.14-0.35$ \\
\hline Tilapia & $12 / 12$ & .25 & $0.07-0.41$ & -- & -- & -- \\
\hline \multicolumn{7}{|c|}{ Amphibians and Reptiles } \\
\hline Bullfrog & -- & -- & -- & $2 / 2$ & 0.06 & $0.01-0.38$ \\
\hline Spiny softshell turtle & & & & & & \\
\hline (fat) & - & -- & -- & $6 / 6$ & 15.20 & $11.21-21.89$ \\
\hline (egg) & -- & -- & -- & $1 / 1$ & -- & 7.96 \\
\hline \multicolumn{7}{|c|}{ Migratory Birds } \\
\hline Eared grebe (muscle) & $5 / 5$ & 0.28 & $0.17-1.1$ & - & -- & -- \\
\hline Northern shoveler (muscle) & -- & - & -- & $6 / 6$ & 0.58 & $0.17-2.14$ \\
\hline Ruddy duck (muscle) & $30 / 30$ & .27 & $0.096-1.55$ & -- & -- & -- \\
\hline \multicolumn{7}{|l|}{ White-faced ibis } \\
\hline (fat) & -- & -- & -- & 9/9 & 5.79 & $3.9-11.72$ \\
\hline (liver) & -- & -- & -- & $9 / 9$ & 6.06 & $3.14-9.85$ \\
\hline \multicolumn{7}{|c|}{ Resident Birds } \\
\hline \multicolumn{7}{|l|}{ American coot } \\
\hline (liver) & -- & $\therefore-$ & -- & $3 / 3$ & 0.01 & $0.01-0.03$ \\
\hline (muscle) & -- & -- & -- & $4 / 4$ & .22 & $0.09-0.45$ \\
\hline Barn owl (muscle) & -- & -- & -- & $1 / 1$ & -- & 2.71 \\
\hline \multicolumn{7}{|l|}{ Black-necked stilt } \\
\hline (carcass) & $38 / 38$ & 0.69 & $0.02-2.76$ & -- & -- & -- \\
\hline (egg) & $84 / 84$ & 2.57 & $0.05-12.1$ & -- & -- & -- \\
\hline Cattle egret & -- & -- & -- & $2 / 2$ & 2.32 & $2.21-2.43$ \\
\hline $\begin{array}{l}\text { Double-crested cormorant } \\
\text { (muscle) }\end{array}$ & $3 / 3$ & 1.1 & $0.38-4.92$ & -- & -- & -- \\
\hline Great blue heron (muscle) & -- & -- & -- & $1 / 1$ & -- & 13.03 \\
\hline Herring gull & $1 / 1$ & -- & 2.81 & -- & -- & -- \\
\hline
\end{tabular}


Table 14. $p, p^{\prime}-D D E$ concentration in biota from the Salton Sea area, 1986-90

[Concentrations in micrograms per gram, wet weight; --, no data; $\mathrm{N}$, number of samples collected; DV, number of samples with detectable values; GM, geometric mean (calculated using 1/2 detection limit when data set has more than 50 percent detectable values)]

\begin{tabular}{|c|c|c|c|c|c|c|}
\hline \multirow{2}{*}{ Sample type } & \multicolumn{3}{|c|}{ Salton Sea } & \multicolumn{3}{|c|}{$\begin{array}{c}\text { New, Alamo, and Whitewater Rivers } \\
\text { and irrigation drain }\end{array}$} \\
\hline & N/DV & GM & Range & $\overline{\text { N/DV }}$ & GM & Range \\
\hline \multicolumn{7}{|c|}{ Invertebrates } \\
\hline Asiatic river clam & -- & -- & .- & $12 / 11$ & 0.30 & $0.013-5.5$ \\
\hline Crayfish & -- & -- & -- & $4 / 4$ & .31 & $0.01-0.68$ \\
\hline Pileworm & $2 / 2$ & 0.04 & $0.03-0.04$ & -- & -- & -- \\
\hline Waterboatman & $5 / 5$ & .04 & $0.01-0.07$ & -- & -- & -- \\
\hline \multicolumn{7}{|c|}{ Fish } \\
\hline Bairdiella & $5 / 5$ & 0.10 & $0.08-0.12$ & -- & -- & - \\
\hline Corvina (fillet) & $1 / 1$ & -- & 0.07 & -- & -- & -- \\
\hline Mosquitofish & -- & -- & -- & $3 / 3$ & 0.58 & $0.54-0.61$ \\
\hline Redfin shiner & .- & -- & -- & $1 / 1$ & -. & 5.70 \\
\hline Sailfin molly & -- & -- & -- & $5 / 5$ & .21 & $0.14-0.35$ \\
\hline Tilapia & $12 / 12$ & .23 & $0.07-0.37$ & -- & -- & -- \\
\hline \multicolumn{7}{|c|}{ Amphibians and Reptiles } \\
\hline Bullfrog & -- & -- & -- & $2 / 2$ & 0.06 & $0.01-0.38$ \\
\hline Spiny softshell turtle & & & & & & \\
\hline (fat) & -- & -- & -- & $6 / 6$ & 14.80 & $11.0-21.0$ \\
\hline (egg) & -- & -- & -- & $1 / 1$ & -- & 7.80 \\
\hline \multicolumn{7}{|c|}{ Migratory Birds } \\
\hline Eared grebe (muscle) & $5 / 5$ & 0.28 & $0.17-1.10$ & -- & -- & -- \\
\hline Northern shoveler (muscle) & -- & -- & -- & $6 / 6$ & 0.55 & $0.17-2.10$ \\
\hline Ruddy duck (muscle) & $30 / 30$ & .26 & $0.096-1.50$ & -- & -- & -- \\
\hline White-faced ibis & & & & & & \\
\hline (fat) & -- & .- & -- & 9/9 & 5.57 & $3.70-11.0$ \\
\hline (liver) & -- & -- & -- & $9 / 9$ & 5.93 & $3.10-9.60$ \\
\hline \multicolumn{7}{|c|}{ Resident Birds } \\
\hline American coot & & & & & & \\
\hline (liver) & -- & -- & -- & $3 / 3$ & 0.014 & $0.01-0.03$ \\
\hline (muscle) & & & & $4 / 4$ & .22 & $0.09-0.45$ \\
\hline Barn owl (muscle) & -- & -- & -- & $1 / 1$ & -- & 2.7 \\
\hline \multicolumn{7}{|l|}{ Black-necked stilt } \\
\hline (egg) & $84 / 84$ & 2.54 & $0.05-12.0$ & - & -- & -- \\
\hline (carcass) & $38 / 38$ & .69 & $0.02-2.76$ & -- & -- & -- \\
\hline Cattle egret & - & - & - & $2 / 2$ & 2.3 & $2.20-2.40$ \\
\hline \multicolumn{7}{|l|}{ Double-crested cormorant } \\
\hline (muscle) & $3 / 3$ & 1.13 & $0.38-4.90$ & -- & -- & -- \\
\hline Great blue heron (muscle) & -- & -- & -- & $1 / 1$ & -- & 13.0 \\
\hline Herring gull & $1 / 1$ & -- & 2.80 & - & -- & -- \\
\hline
\end{tabular}




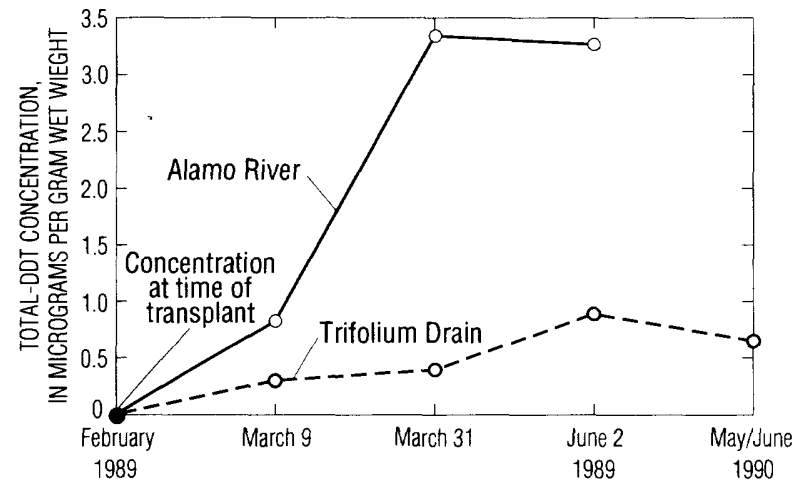

Figure 40. Concentration of total-DDT in transplanted Asiatic river clams.

greater than the geometric mean) was found in a composite clam sample collected from Vail Cutoff Drain. This high DDE concentration may indicate a high DDE load in associated sediment. A composite clam sample from Wister Drain, which receives minimal amounts of drainwater, had no detectable concentrations of any DDT metabolites. Excluding these extreme values, DDT-metabolite concentrations in clams from other river and drain sites (range, 0.16 to $0.47 \mu \mathrm{g} / \mathrm{g}$ wet weight) were similar.

An in situ bioaccumulation test was done to determine if DDT and its metabolites accumulate in clams and, if so, to determine if bioaccumulation varies seasonally. Results of this test, which are presented in figure 40 , show that (in a manner similar to that of boron) concentrations of DDE peaked in late winter to early spring when irrigation activities intensify. During this period, the clams may have been increasingly exposed to DDT metabolites sorbed on soils transported with tailwater runoff and (or) resuspended from sediment in drains (ditches) and rivers. Unlike many other contaminants, $p, p^{\prime}-\mathrm{DDE}$ is highly persistent, which prevents rapid degradation in the environment. Pimental (1971) reported that eastern oysters with about $151 \mathrm{ppm}$ of DDT required approximately 3 months in clean water to eliminate, through depuration, 95 percent of their DDT burden. Other mollusks have been shown to eliminate as much as 75 percent of accumulated DDT after 15 days of flushing. Clams sampled from Trifolium Drain showed a somewhat smaller reduction in their p,p'-DDE burden over a 1-year period-possibly in response to reduced DDE exposure.

DDE concentrations in the transplanted clams collected from the Alamo River were higher than in clams from the Trifolium Drain. This same trend of higher river and lower drain concentrations in biota also was found for selenium and boron. The much
Table 15. p, $p^{\prime}-\mathrm{DDE}$ concentrations in mosquitofish from California drainwater areas and in fish sampled in the National Contaminant Biomonitoring Program

[Concentrations in micrograms per gram, wet weight. CTSMP (California Toxic Substances Monitoring Program) values from California State Water Resources Control Board (1990); Tulare Basin values from Schroeder and others (1988), and values for NCBP (National Contaminant Biomonitoring Program) from Schmitt and others (1985, 1990); ND, not detected]

\begin{tabular}{lrr}
\hline Location & $\begin{array}{c}\text { Geometric } \\
\text { mean }\end{array}$ & Range \\
\hline Salton Sea area & & \\
Detailed study & 0.58 & $0.54-0.61$ \\
CTSMP & $\left(^{1}\right)$ & 1.10 \\
Tulare Basin & .14 & $0.10-0.34$ \\
NCBP 1981 & .20 & $0.01-2.57$ \\
NCBP 1984 & .19 & ND-4.74 \\
\hline
\end{tabular}

${ }^{1}$ One composite.

higher concentration of suspended sediment (Schroeder and others, 1993, table 5) and the somewhat higher DDE concentration in bottom material (Setmire and others, 1990, table 10) from the Alamo River, in comparison with the Trifolium drains, may account for the greater bioaccumulation of contaminants in aquatic invertebrates from the Alamo River. These contaminants can be transferred to higher trophic levels in the food chains and cause adverse effects in higher level consumers.

Fish

Freshwater fish.--The highest mean concentration $(0.58 \mu \mathrm{g} / \mathrm{g}$ wet weight, in mosquitofish) and highest overall concentration $(5.7 \mu \mathrm{g} / \mathrm{g}$ wet weight, in redfin shiner) of p,p'-DDE for whole-fish samples in the Imperial Valley were from river and drain sites (table 14). According to California Toxic Substances Monitoring Program synopses (California Toxic Substances Monitoring Program, 1983a, 1983b), elevated levels of total DDT (among the highest found in the State) persisted in bottom-feeding fish in the Alamo and New Rivers in 1983. Results from 1989 show that total-DDT concentrations in fish (fillet samples) from the Alamo and New Rivers were lower than earlier concentrations, indicating a downward trend.

Mean DDE concentrations in mosquitofish from river and drain sites in the Imperial Valley are higher than in fish collected from other locations in California and nationwide (table 15). The mean DDE 
concentration in mosquitofish from this study, 0.58 $\mu \mathrm{g} / \mathrm{g}$ wet weight, is almost 3 times greater than the National Contaminant Biomonitoring Program (NCBP) mean for both 1981 and 1984. Concentrations of p,p'-DDE in mosquitofish also were higher than concentrations in mosquitofish from the Tulare Basin reported by Schroeder and others (1988). The maximum DDE concentration in Tulare Basin mosquitofish $(0.34 \mu \mathrm{g} / \mathrm{g}$ wet weight) was below the minimum concentration reported for mosquitofish $(0.54 \mu \mathrm{g} / \mathrm{g}$ wet weight) in the Salton Sea area. Similarly high DDE concentrations in mosquitofish were found in 1989 in Warren Drain in the Imperial Valley (California Environmental Protection Agency, 1991).

Mosquitofish from contaminated sites have shown resistance to DDT toxicity (Vinson and others, 1963; Andreasen, 1985). Although p,p'-DDE concentrations in mosquitofish from the Imperial Valley were elevated in comparison with concentrations for mosquitofish from the Tulare Basin (table 15), concentrations were at levels not known to adversely affect fish directly.

An elevated p,p'-DDE concentration of $5.7 \mu \mathrm{g} / \mathrm{g}$ wet weight in a redfin shiner from the Whitewater River, at the north end of the Salton Sea, exceeded the highest concentrations found in nationwide monitoring in 1980-81 (2.57 $\mu \mathrm{g} / \mathrm{g}$ wet weight) and $1984(4.74 \mu \mathrm{g} / \mathrm{g}$ wet weight) (Schmitt and others, $1985,1990)$. These results indicate the presence of highly elevated concentrations of DDT and its metabolites in the Coachella Valley at the north end of the Salton Sea.

Saltwater fish.--Mean concentrations of p,p'-DDE in tilapia from the Salton Sea $(0.23 \mu \mathrm{g} / \mathrm{g}$ wet weight) were slightly higher than in tilapia composites from the lower Rio Grande River $(0.16 \mu \mathrm{g} / \mathrm{g}$ wet weight; Wells and others, 1988). Whole-body mean DDE concentration in bairdiella was less than one-half the levels found in tilapia. Both these concentrations were slightly higher than those (in fillets) for bairdella collected from the Salton Sea as part of the 1989 CTSMP (California Environmental Protection Agency, 1991). Because concentrations were low in wholebody bairdiella samples, DDT and its metabolites probably are not a concern for the health of adult bairdiella.

Total-DDT concentration in a fillet sample of orangemouth corvina, the top aquatic predator of the Salton Sea, was the lowest concentration found in any fish sampled (fig. 41). DDE concentrations in corvina were comparable to 1989 CTSMP bairdiella fillet concentrations (California Environmental Protection Agency, 1991).

Although organochlorine pesticide levels in adult sportfish (corvina, bairdiella, and tilapia) examined in this investigation were low, there is evidence that ichthyoplankton are much more sensitive to environmental contamination than are adults. Ichthyoplankton of sportfish sampled from the Salton Sea by Matsui (1989) had deformity frequencies similar to those reported in areas with known contaminant problems. Matsui (1989) concluded that some form of environmental contamination caused a 6- to 11percent mortality of sportfish eggs. Embryonic aberrations were significantly higher in earlier stages and represent the effect of environmental stress at a critical stage of development (the period between cleavage and gastrulation). The types of malformations reported were not specific to a particular contaminant, but may represent synergistic effects of contaminants and changes in temperature and salinity.

Whether recent use of DDT has occurred in the Imperial Valley and (or) Mexico seems doubtful. Generally, fish collected from areas of historical DDT use have body burdens with a proportional composition of 70 percent DDE, 20 percent DDD, and 10 percent DDT. All fish DDT/DDE/DDD ratios from this study support the conclusion by Schmitt and others $(1985,1990)$ that DDT has not been used recently in the Southwestern United States.

\section{Amphlblans and Reptlles}

DDE concentrations in fat and eggs from spiny softshell turtles greatly exceeded levels found in bullfrogs (table 14). The higher concentration in turtles may be due to differences in food habits or in lipid content between the samples. Little is known about the effects of DDT on amphibians and reptiles. Reptiles have been reported to be more sensitive to pesticide effects than are homotherms (Hall, 1980). Reptile mortality occurred at dose levels as low as 10 $\mu \mathrm{g} / \mathrm{g}$ body weight, a level that generally is safe for birds and mammals (Rudd and Genelly, 1956). DDT applications of 0.3 to $0.7 \mathrm{~kg} / \mathrm{ha}$ to agricultural land caused both sublethal and lethal effects on snakes, turtles, and lizards (Herald, 1949).

DDE-residue concentrations found in Salton Sea spiny softshell turtles are within the range of values for reptiles reported by Hall (1980). Softshell turtles, a high-trophic-level predator in river and drain 


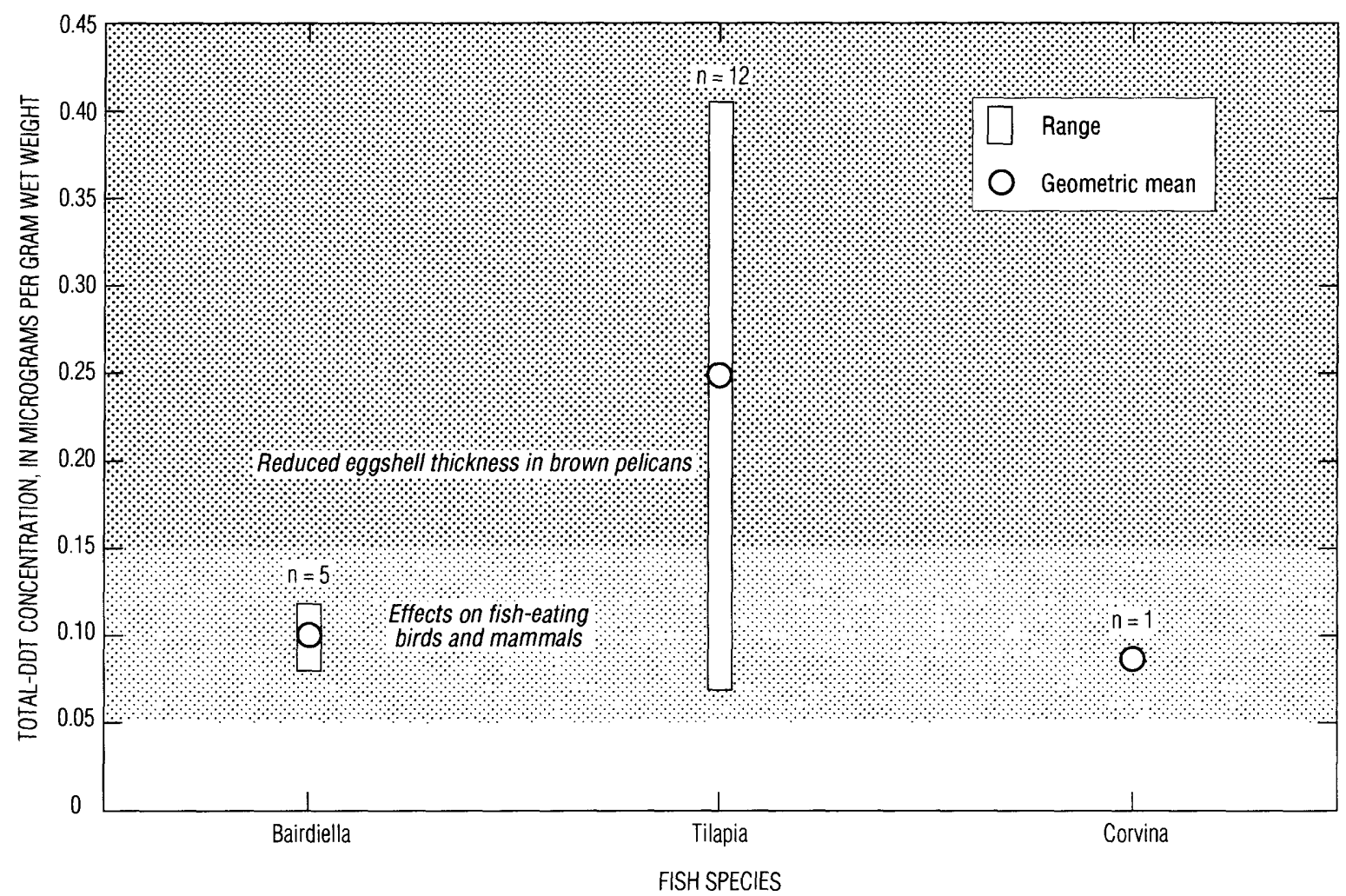

Figure 41. Concentration of total DDT for three species of fish from the Salton Sea, 1988-90, and dietary thresholds for fish-eating birds and mammals. Threshold for effects on fish-eating birds and mammals from National Academy of Sciences, National Academy of Engineering (1973). Threshold for reduced eggshell thickness in brown pelican from Anderson and others (1975).

ecosystems, feed primarily on crayfish, mosquitofish, sailfin mollies, and frogs. DDT-metabolite concentrations in these food items in the Imperial Valley were considerably lower than concentrations found in turtle fat, thus indicating significant biomagnification.

\section{Birds}

Migratory blrds.--DDE concentrations in carcass and muscle samples are important indicators of DDT exposure for individual birds. These tissues also are potential food for birds of prey and other predators. Three migratory species of waterfowl were collected in the Imperial Valley: northern shoveler, ruddy duck, and eared grebe. Northern shoveler from rivers and drains had higher mean and maximum concentrations of DDE in muscle samples (table 14) than did eared grebes and ruddy ducks from the Salton Sea. Similar results were found at other trophic levels; that is, river and drain species had higher DDE-residue levels than species that primarily use the Salton Sea.

DDE concentrations in Imperial Valley waterfowl were comparable to those reported for mallards (not detectable to $1.4 \mu \mathrm{g} / \mathrm{g}$ wet weight) and wood ducks ( 0.20 to $4.0 \mu \mathrm{g} / \mathrm{g}$ wet weight) from the DDEcontaminated Yazoo NWR in Mississippi (White and others, 1988). Blus and others (1987) found that nesting mallards in areas with low (less than 10:1) DDE:DDT ratios (that is, areas of recent DDT use) had p,p'-DDE concentrations, in breast muscle, that ranged from 0.02 to $0.63 \mu \mathrm{g} / \mathrm{g}$ wet weight. DDE concentrations in waterfowl from this study were well above those reported by Blus and others (1987); however, the DDE/DDT ratios (greater than 56:1) were very high, indicating no recent use of DDT.

Current levels of DDT and its metabolites in sediment, water, and biota from the Imperial Valley still may pose a threat to migratory waterfowl. Ohlendorf and Miller (1984) collected northern pintails throughout California and found the highest DDE concentrations, comparable to values from this study, at the Salton Sea. Mora and others (1987) collected pintails seasonally in California and Mexico and also found the highest concentrations at the Salton Sea. In addition, they found that the highest concentrations were in winter birds, which indicated that accumulation occurred on the wintering grounds. 
Waterfowl of the Imperial Valley ingested a diet with DDE concentrations of 0.01 to $5.7 \mu \mathrm{g} / \mathrm{g}$ wet weight, depending on individual food habits and on habitats utilized. A dietary intake of 2.8 to $3.0 \mu \mathrm{g} / \mathrm{g}$ wet weight of DDE has adverse effects on reproduction of waterfowl (Heath and others, 1969; Longcore and Stendell, 1977). Some of the plant material and (or) invertebrates on which waterfowl at the Salton Sea typically feed had DDE concentrations well above the $2.8 \mu \mathrm{g} / \mathrm{g}$ reproductive threshold. Food consumed by fish-eating birds of the Imperial Valley and Salton Sea may exceed not only the $2.8 \mu \mathrm{g} / \mathrm{g}$ threshold, but also the National Academy of Sciences, National Academy of Engineering (1973) levels for the protection of predators (based on whole fish) for freshwater species $(1.0 \mu \mathrm{g} / \mathrm{g}$ wet weight) or for saltwater species $(0.05 \mu \mathrm{g} / \mathrm{g}$ wet weight).

Liver and fat samples of white-faced ibis had some of the highest DDE concentrations in birds found in the Imperial Valley. This migratory bird feeds mainly in agricultural fields on terrestrial invertebrates that are in direct contact with DDEcontaminated soils. For ibis in the Carson Lake area, Henny and Herron (1989) reported a decrease in nesting success when DDE concentrations were greater than $4 \mu \mathrm{g} / \mathrm{g}$ wet weight in eggs, and a decrease in brood size at concentrations greater than $8 \mu \mathrm{g} / \mathrm{g}$. Eggshell thickness was reduced by 23 percent at DDE concentrations of 8 to $16 \mu \mathrm{g} / \mathrm{g}$ and by 27 percent at concentrations greater than $16 \mu \mathrm{g} / \mathrm{g}$ (Henny and Herron, 1989).

White-faced ibis liver and fat samples collected in the Imperial Valley had DDE concentrations (geometric mean: liver, $5.93 \mu \mathrm{g} / \mathrm{g}$ wet weight; fat, 5.57 $\mu \mathrm{g} / \mathrm{g}$ wet weight) similar to concentrations in ibis eggs collected at Carson Lake, where reproductive problems were documented. Egg contaminant levels are determined primarily by contaminant burden of the female (which is mostly in liver and fat tissue) at the wintering ground prior to egg formation and laying (Ohlendorf and others, 1978). It is suspected that many wintering ibis at Salton Sea nest at Carson Lake; therefore, DDE probably is being transferred out of the Salton Sea Basin by ibis.

Pelicans use the Salton Sea throughout the year; however, white pelicans are most numerous during spring and autumn, and California brown pelicans are most numerous $(5,000$, estimated, in 1990) during post-breeding dispersal (U.S. Fish and Wildlife Service, 1987). White pelicans, which historically nested at the Salton Sea, now use it primarily as a major staging area for the spring migration northward.
DDE found at elevated concentrations in white pelican eggs collected from the Klamath Basin, California, is believed to have been accumulated in wintering grounds to the south such as the Salton Sea (Boellstorff and others, 1985).

Anderson and others (1975) found that a dietary intake of $0.15 \mu \mathrm{g} / \mathrm{g}$ total DDT resulted in egg concentration of $97 \mu \mathrm{g} / \mathrm{g}$ (lipid weight), which is above levels associated with reduced eggshell thickness and productivity in the endangered California brown pelican. The increasing late summer population of California brown pelicans at the Salton Sea feed on a variety of fish. A comparison of total-DDT concentrations in fish collected in this study with dietary thresholds set for DDE, and with National Academy of Sciences, National Academy of Engineering (1973) guidelines for predators $(1 \mu \mathrm{g} / \mathrm{g}$ wet weight), indicates that California brown pelicans at the Salton Sea may consume high levels of DDT and its metabolites. These high levels could result in an increase of DDE in eggs - which, in turn, likely would result in reduced eggshell thickness and belownormal productivity.

Three birds of prey-osprey and two federally endangered species, peregrine falcon and bald eagle-that uncommonly are found at the Salton Sea also may be exposed to high concentrations of DDE in food items such as fish, shorebirds, and waterfowl. These species have suffered population declines as a result of eggshell thinning and lowered productivity caused by excessive DDE accumulation.

Resident birds.--DDE concentrations in carcass and muscle samples of resident birds were the most elevated of all samples collected in this study (table 14). This is as expected because resident birds consume DDE-contaminated food throughout the year; whereas, migratory birds are present in the study area only during winters. Black-necked stilts had the highest mean and maximum carcass and muscle concentrations of any resident bird for which more than three samples were collected.

DDE concentrations in Salton Sea resident cormorants (table 16) were comparable to concentrations found by King (1989a) in resident olivaceous and double-crested cormorants from a heavily contaminated location (Houston Shipping Channel) in Texas. However, cormorants collected as part of the lower Colorado River reconnaissance investigation (Radtke and others, 1988) had a mean DDE concentration four times greater than that found at the Salton Sea. Concentrations in cormorant samples from the Salton 
Table 16. $p, p^{\prime}-D D E$ concentrations in cormorant tissues from the Salton Sea area and from contaminated sites in the Southern and Western United States

[Concentrations in micrograms per gram, wet weight. Values for Houston Shipping Channel from King (1989a) and for lower Colorado River from Radtke and others (1988). N, number of samples analyzed; DV, number of samples with detectable values; GM, geometric mean]

\begin{tabular}{llccc}
\hline \multicolumn{1}{c}{ Species } & \multicolumn{1}{c}{ Location } & N/DV & GM & Range \\
\hline Double-crested cormorant & Salton Sea & $3 / 3$ & 1.13 & $0.38-4.9$ \\
Olivaceous cormorant & Houston Shipping Channel & $10 / 10$ & .80 & $0.20-2.5$ \\
Double-crested cormorant & Houston Shipping Channel & $10 / 10$ & .93 & $0.40-2.3$ \\
Double-crested cormorant & Lower Colorado River & $9 / 9$ & 4.3 & $2.10-6.6$ \\
\hline
\end{tabular}

Sea were 5 to 11 times greater than in fish samples (bairdiella, tilapia) from the Salton Sea-a bioaccumulation factor lower than that (27 times) reported by King (1989a). The differences in bioaccumulation factors may be due to species (of cormorant) differences.

DDE concentration in great blue heron muscle was 2 to 80 times greater than the concentration in fish species eaten by herons. However, this may not be significant because DDT toxicity to the great blue heron is low (Fitzner and others, 1988) and DDE concentration in the heron tissue was well below concentrations associated with mortality or reproductive problems in Ardeids (on the basis of studies by Ohlendorf and others, 1979, and Blus and others, 1980).

Egg collection for several species of birds with different feeding strategies and habitat preferences was planned for this investigation. Concentrations of DDE in eggs reflect levels in the female at the time the egg was laid and may influence reproductive success of birds (Ohlendorf and others, 1978). However, because of a recent decline in nesting throughout the Salton Sea area, particularly in fisheating birds (Salton Sea National Wildlife Refuge, 1990), sampling of eggs was confined to a single species (black-necked stilt). The number of active nests of colonial water birds at the Salton Sea (table 17) declined 80 percent during 1986-91. In a south Texas study of black skimmers, Custer and Mitchell (1987) found decreased hatching success to be correlated with DDE concentration. The black skimmer population has decreased an estimated 40 percent since 1987. Although the reason for the decline in nesting at the Salton Sea is not yet understood, contaminants are suspected to have been a major factor.
Monitoring results for active nests of colonial water birds over a period of 6 years (1986-91) are summarized in table 17 . Species showing the sharpest declines are the great blue heron, cattle egret, and double-crested cormorant. Contaminant effects such as eggshell thinning may be partially responsible for these declines.

Black-necked stilts were the only birds for which eggs were collected for chemical analyses. Concentrations of DDE were more than twice as high as those of American avocet eggs (whose levels were not of concern) collected from evaporation ponds in southern San Joaquin Valley (Schroeder and others, 1988). The mean p,p'-DDE concentration in stilt eggs was greater than the $2.0 \mathrm{ppm}$ wet weight DDE threshold associated with 10-percent eggshell thinning in osprey eggs (Wiemeyer and others, 1988), and slightly below the reproductive-impairment threshold concentration (3.0 ppm wet weight for eggs) for brown pelican (Blus, 1982). Stilt-egg DDE concentrations and documented thresholds for other bird species are given in figure 42. A log-log regression of DDE concentration in stilt eggs from the Imperial Valley against eggshell thickness indicates a 7-percent thinning for the highest DDE concentration $(12 \mu \mathrm{g} / \mathrm{g}$ wet weight), in comparison with the lowest reportable concentration $(0.26 \mu \mathrm{g} / \mathrm{g}$ wet weight) (fig. 43). Although the statistical significance of the correlation $\left(r^{2}=0.19, \alpha=0.254\right)$ is not very strong, eggshell thinning has been found, in further investigations by the U.S. Fish and Wildlife Service, in at least five species of colonial nesting birds in the Salton Sea area.

Ohlendorf and Marois (1990) found that the mean concentration of p,p'-DDE in eggs of black-crowned night herons collected at Salton Sea in 1985 exceeded the $8 \mu \mathrm{g} / \mathrm{g}$ wet weight reproductive success threshold for this species. The mean concentration was 
Table 17. Active nests of colonial water birds at major rookeries along the Salton Sea shoreline, 1986-91

[Based on N.D. Hogg, Santa Monica College, Santa Monica, Calif., written commun., 1992, and U.S. Fish and Wildlife Service, written commun., 1992]

\begin{tabular}{lrrrrrr}
\hline \multicolumn{1}{c}{ Species } & \multicolumn{5}{c}{ Number of active nests } \\
\cline { 2 - 7 } & 1986 & 1987 & 1988 & 1989 & 1990 & 1991 \\
\hline Black-crowned night heron & 5 & 12 & 0 & 35 & 98 & 160 \\
Cattle egret & 2,094 & 1,873 & 1,700 & 798 & 42 & 25 \\
Double-crested cormorant & 24 & 63 & 57 & 0 & 0 & 0 \\
Great blue heron & 362 & 261 & 211 & 10 & 19 & 20 \\
Great egret & 49 & 105 & 292 & 93 & 118 & 151 \\
Green-backed heron & 0 & 0 & 2 & 0 & 4 & 1 \\
Snowy egret & 76 & 109 & 49 & 260 & 226 & 160 \\
$\quad$ Total . . . . . . . . . . & 2,610 & 2,423 & 2,311 & 1,196 & 507 & 517 \\
\hline
\end{tabular}

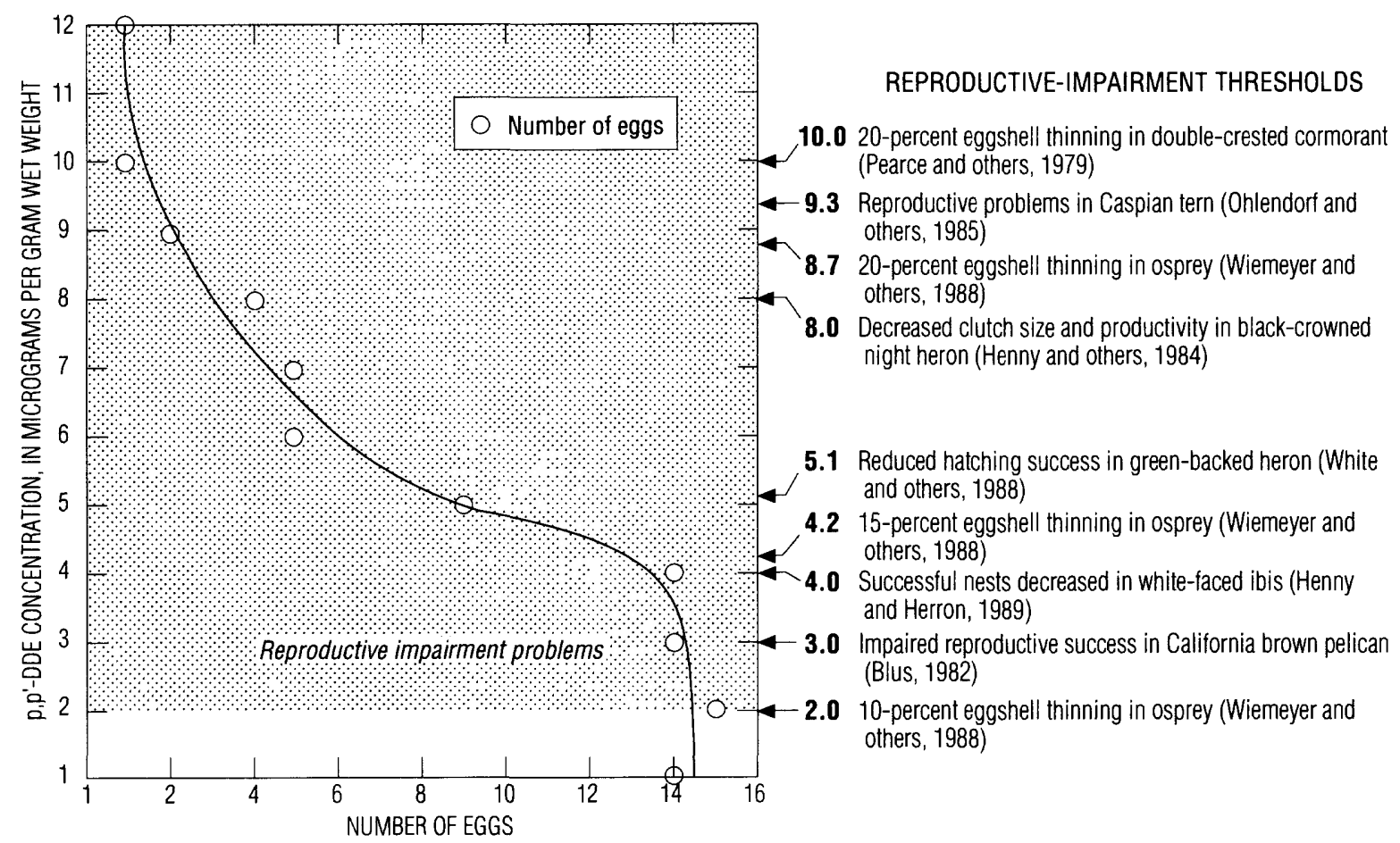

Figure 42. Concentration of $p, p^{\prime}-D D E$, in black-necked stilt eggs from the Imperial Valley, 1988-90, and reproductive-impairment thresholds for selected bird species.

comparable to concentrations (in 1972-73) in Lake Ontario night heron eggs (11 to $12 \mu \mathrm{g} / \mathrm{g}$; Price, 1977) that were associated with a hatching success rate of 36 to 39 percent, which is well below normal. Also, Ohlendorf and Marois (1990), Henny and others (1984), and Henny and Blus (1986) found that night herons nesting at Ruby Lake, Nevada, accumulated DDE while overwintering in southern California and Arizona.
In 1975-when legal use of DDT (as a minor component of dicofol in the United States and as technical DDT in Mexico) still was prevalent in Imperial Valley-snowy egret eggs collected from the Salton Sea had a mean DDE concentration of 1.7 $\mu \mathrm{g} / \mathrm{g}$ wet weight (range 0.8 to $4.2 \mu \mathrm{g} / \mathrm{g}$ wet weight) (Platter, 1976). Platter concluded that DDE concentrations were significantly correlated with eggshell thickness, and that pesticide residues were associated 


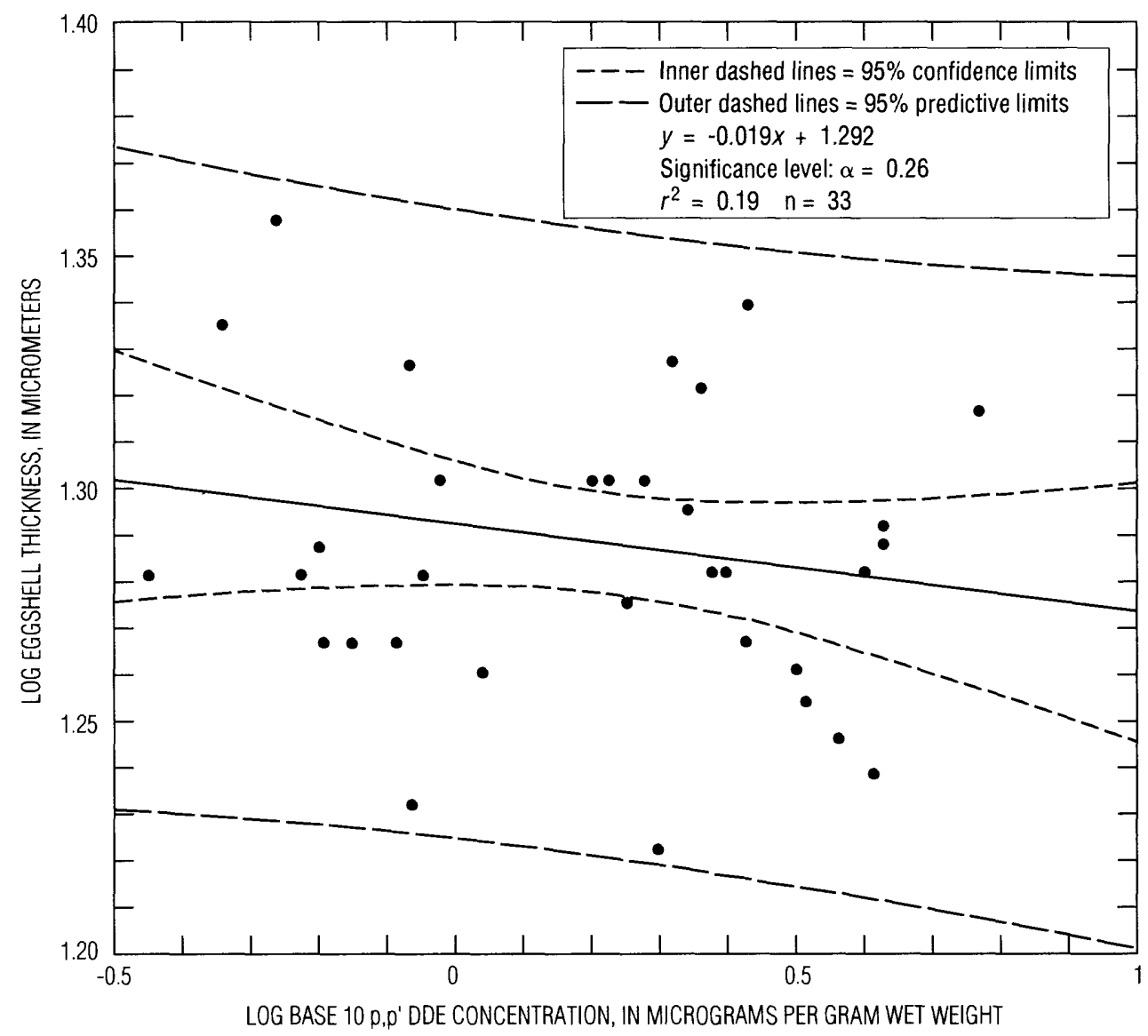

Figure 43. Regression plot of log p,p'-DDE concentration and log eggshell thickness for black-necked stilts in the Imperial Valley, 1988-89.

with reproductive problems that included increased egg mortality at Salton Sea colonial nesting rookeries. Eggshell thinning for snowy egrets and cattle egrets was 18.8 and 17.3 percent, respectively, in comparison with 1953 (pre-DDT) museum eggs. This collective historical evidence shows conclusively that DDE has caused significant reproductive effects in colonial nesting birds throughout the Imperial Valley and Salton Sea area.

This study shows that mean DDE concentrations for black-necked stilt neighborhoods (about 5 acres) within the Imperial Valley were statistically different $(F$ ratio $=5.938, \rho=0.0001)$. The neighborhoods were put into statistically homogeneous groups (table 18) that had some overlap. However, the group with the highest mean concentrations (group F) consisted of manmade ponds ( $\mathrm{RH}$ pond, site B34) that were constructed on land previously used for agriculture. It is very likely that past DDT use resulted in a residual buildup in soil, and that the residues became mobilized as the ponds were created.
Birds of the Salton Sea are ingesting food items with DDE concentrations ranging from 0.01 to 21.0 $\mu \mathrm{g} / \mathrm{g}$ wet weight. Waterfowl and shorebirds feeding on invertebrates are ingesting food items containing (relatively low) DDE concentrations that range from 0.01 to $0.68 \mu \mathrm{g} / \mathrm{g}$ wet weight. In contrast, fish-eating birds are ingesting DDE at higher concentrations, 0.07 to $5.7 \mu \mathrm{g} / \mathrm{g}$ wet weight, and predatory birds are ingesting food items containing concentrations as high as $21.0 \mu \mathrm{g} / \mathrm{g}$ wet weight. Thus, resident fish-eating birds and birds of prey are at the greatest risk of DDE contamination within the Imperial Valley because they are feeding on items which are at the highest part of the food chains and which have the highest DDE concentrations.

Resident shorebirds such as the black-necked stilt had elevated concentrations of DDE in carcass and eggs from an apparently small dietary intake $(0.01$ to $0.07 \mu \mathrm{g} / \mathrm{g}$ wet weight in pileworms and waterboatmen). The resultant bioaccumulation factor in body tissues is as great as 1,200 . There is concern that 
Table 18. p, $p^{\prime}$-DDE concentration in black-necked stilt eggs from neighborhoods in the Imperial Valley, $1988-89$

[Location of sites shown in figure 10. Concentrations in micrograms per gram, wet weight. Group: homogeneous groups determined at 95-percent confidence interval using Tukey's multiple comparison test (Statgraphics, 1988)]

\begin{tabular}{llccl}
\hline Site & \multicolumn{1}{c}{ Location } & $\begin{array}{c}\text { Number of } \\
\text { samples }\end{array}$ & $\begin{array}{c}\text { Mean p-p'-DDE } \\
\text { concentration }\end{array}$ & Group \\
\hline B25 & Vail Cutoff Drain & 5 & 1.00 & A \\
B15 & New River delta & 10 & 1.97 & AB \\
B39 & McKendry Road & 5 & 2.41 & ABC \\
B1,B24 & Salton Sea National Wildlife & & & \\
& $\quad$ Refuge (Unit 1) and & 15 & 2.57 & ABCD \\
& $\quad$ Trifolium 14 Drain & 27 & 3.33 & ABCDE \\
B17 & New River at Rio Bend & 9 & 4.60 & BCDEF \\
B37 & Hazard Pond & 4 & 6.10 & CEF \\
B36 & Reidman Pond & 9 & 6.46 & F \\
B34 & RH Pond & & \\
\hline
\end{tabular}

eggshell thickness of stilts was adversely affected by DDE even though DDE concentrations in their food items were low, and that more environmentally sensitive species such as the endangered Yuma clapper rail may, therefore, also be affected. Significant declines in colonial water-bird populations also may be related to elevated DDE concentrations and other contaminants. In addition, gulls and mammals (such as the raccoon) that eat bird eggs and fish also are exposed to DDE.

\section{Food-Chaln Relations}

Although DDT is a contaminant that does not originate directly from irrigation drainwater, DDT and its metabolites (DDE and DDD) are mobilized by tailwater runoff or by resuspension of sediment in the drains and rivers. The low water solubility and high lipophilicity of DDT and its metabolites have resulted in their bioaccumulation in fish and wildlife throughout the United States (U.S. Environmental Protection Agency, 1980a).

Bioaccumulation of DDE through food chains has been documented in several studies, including Hickey and Anderson (1968) and King (1989a, 1989b). The more complex and longer a food chain is, the more likely it is that toxic effects of DDE will be seen in species at higher trophic levels. Species associated with river and drain (freshwater) habitats typically had higher concentrations of p,p'-DDE and total DDT than similar species associated with the Salton Sea (estuarine and saltwater habitats). This difference in concentrations may be due to closer contact of river and drain species with the main source of
DDT - agricultural fields (through tailwater runoff and resuspended sediments). In addition, birds that feed on invertebrates and other food items in fields (whitefaced ibis and cattle egret, for example) had some of the highest concentrations of DDE found during the study.

Concentrations of p,p'-DDE in food items sampled in the Salton Sea and rivers and drains, and thresholds for adverse effects on the predators within each system, are shown in figures 44 and 45 . On the basis of these data, the risk of DDT contamination in the Salton Sea area is highest for raptors (predatory birds). Also of concern are birds feeding in agricultural fields. Earthworms, a prey item of these birds, reflect the exposure to DDT in soil and are known to accumulate high concentrations of organochlorine insecticides (Byer and Krynitsky, 1989).

The Salton Sea and the Imperial Valley have the highest DDE concentrations recorded in the State of California in fish (California Toxic Substances Monitoring Program, 1983a, 1983b) and birds (Ohlendorf and Miller, 1984; Mora and others, 1987; Ohlendorf and Marois, 1990). Ultimately, birds are at the greatest risk of DDE contamination in the Imperial Valley. Resident bird species typically had higher DDE concentrations than migratory species in the Imperial Valley. A north-south organochlorine pesticide contaminant gradient (increasing from north to south) in migratory waterfowl was found by Ohlendorf and Miller (1984) and Mora and others (1987) along with an opposite pattern farther south in Mexican wintering grounds. On the basis of DDE/DDT ratios and DDT/DDE/DDD proportions, there is little evidence of recent DDT use in the 


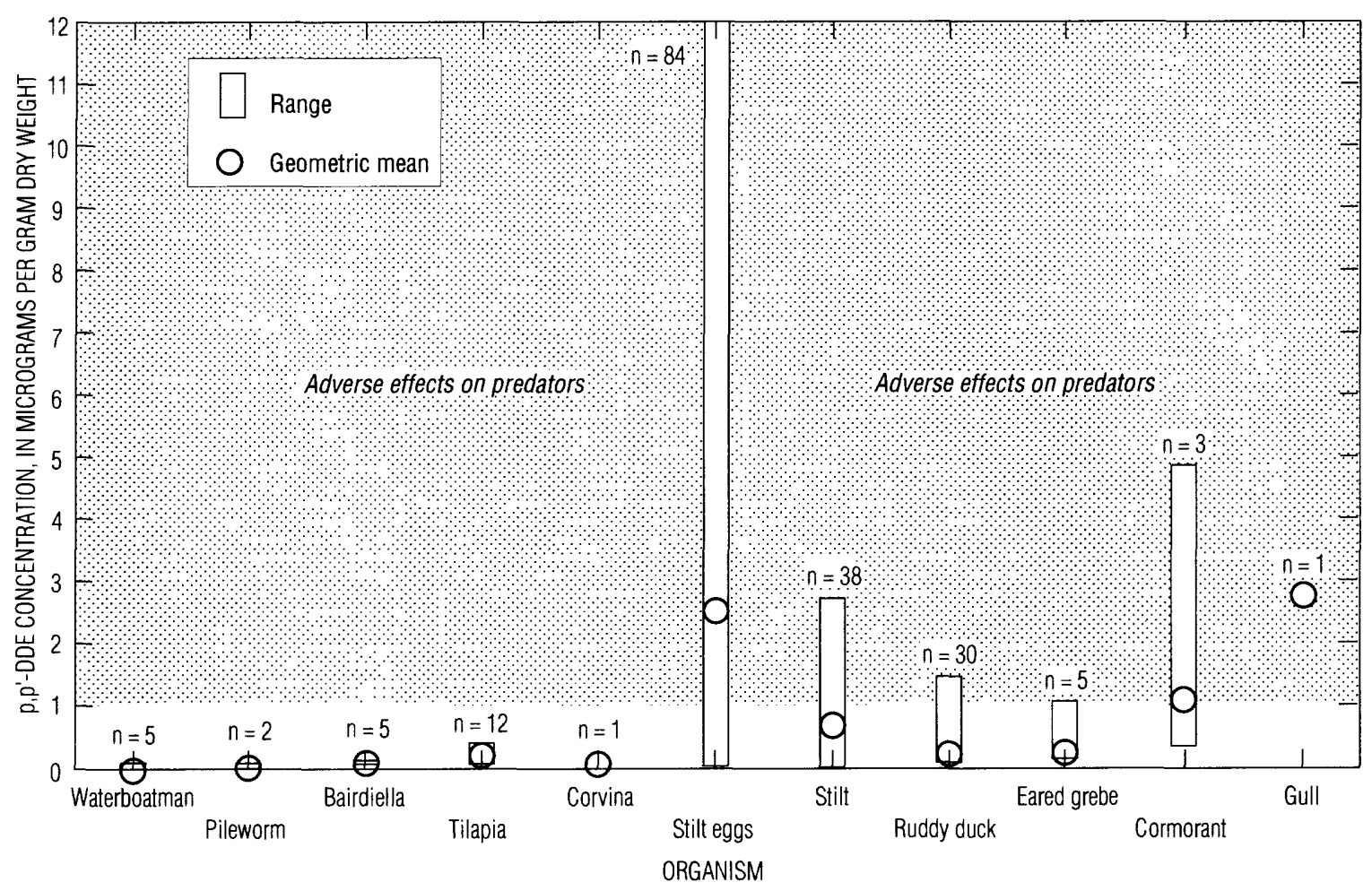

Figure 44. Concentration of $\mathrm{p}, \mathrm{p}^{\prime}-\mathrm{DDE}$ in food-chain organisms of the Salton Sea, 1988-90, and dietary threshold for predators. Adverse-effects threshold from National Academy of Sciences, National Academy of Engineering (1973).

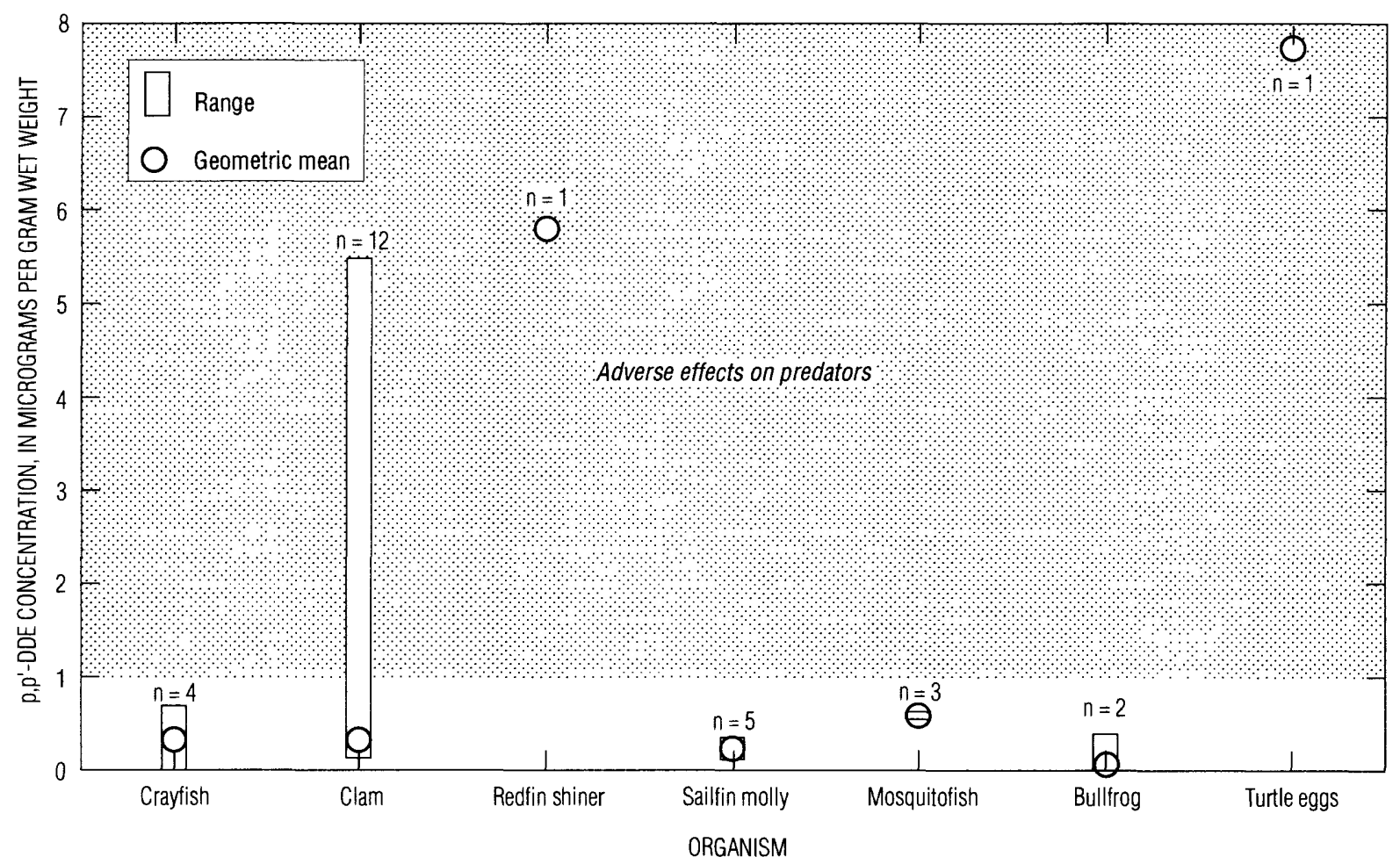

Figure 45. Concentration of $p, p^{\prime}-D D E$ in food-chain organisms of rivers and drains in the Imperial Valley, 1988-90, and dietary threshold for predators. Adverse-effects threshold from National Academy of Sciences, National Academy of Engineering (1973). 
Table 19. Concentrations of selected organochlorine pesticides in biotic samples collected from the Salton Sea area and the Imperial Valley, 1986-90

[Concentrations in micrograms per gram (parts per billion), wet weight. $<$, less than indicated reporting limit]

\begin{tabular}{|c|c|c|c|c|}
\hline \multirow[t]{2}{*}{ Compound } & \multirow{2}{*}{$\begin{array}{c}\text { Number of samples } \\
\text { analyzed }\end{array}$} & \multicolumn{2}{|c|}{$\begin{array}{l}\text { Samples with } \\
\text { detectable residue }\end{array}$} & \multirow{2}{*}{$\begin{array}{l}\text { Concentration } \\
\text { (range) }\end{array}$} \\
\hline & & Number & Percent & \\
\hline Oxychlordane & 269 & 96 & 35.7 & $<0.01-0.64$ \\
\hline alpha-Chlordane & 269 & 39 & 14.5 & $<0.01-0.24$ \\
\hline gamma-Chlordane & 269 & 8 & 3.0 & $<0.01-0.08$ \\
\hline cis-Nonachlor & 269 & 8 & 3.0 & $<0.01-0.11$ \\
\hline trans-Nonachlor & 269 & 55 & 20.4 & $<0.01-0.29$ \\
\hline Heptachlor & 269 & 0 & 0 & $<0.01$ \\
\hline Heptachlor epoxide & 269 & 50 & 18.6 & $<0.01-0.06$ \\
\hline Methoxychlor & 11 & 3 & 27.3 & $<0.01-0.03$ \\
\hline Endrin & 269 & 9 & 3.3 & $<0.01-0.03$ \\
\hline Dieldrin & 269 & 162 & 60.2 & $<0.01-0.85$ \\
\hline Aldrin & 37 & 1 & 2.7 & $<0.01-0.01$ \\
\hline alpha-BHC ${ }^{1}$ & 223 & 0 & 0 & $<0.01$ \\
\hline beta-BHC ${ }^{1}$ & 223 & 80 & 35.9 & $<0.01-0.36$ \\
\hline gamma-BHC (lindane) ${ }^{1}$ & 223 & 0 & 0 & $<0.01$ \\
\hline delta-BHC ${ }^{1}$ & 223 & 2 & .9 & $<0.01-0.05$ \\
\hline Hexachlorobenzene & 223 & 100 & 44.8 & $<0.01-2.9$ \\
\hline Endosulfan I & 11 & 1 & 9.1 & $<0.01-0.01$ \\
\hline Endosulfan II & 11 & 1 & 9.1 & $<0.01-0.02$ \\
\hline Endosulfan sulfate & 11 & 1 & 9.1 & $<0.01-0.02$ \\
\hline Mirex & 223 & 4 & 1.7 & $<0.01-0.04$ \\
\hline DCPA & 11 & 7 & 63.6 & $<0.01-0.32$ \\
\hline Dicofol & 11 & 0 & 0 & $<0.01$ \\
\hline Tetradifon & 11 & 0 & 0 & $<0.01$ \\
\hline Toxaphene & 269 & 21 & 7.8 & $<0.01-7.0$ \\
\hline
\end{tabular}

${ }^{1}$ Various isomers of hexachlorohexane, of which only the gamma isomer (lindane) has insecticidal activity.

Imperial Valley. Although elevated DDE residues found in this study may be attributed, in part, to dicofol use (Hunt and others, 1986), the residues primarily are a result of past heavy use of DDT.

\section{OTHER ORGANOCHLORINE PESTICIDES}

A total of 24 organochlorine pesticides (other than DDT and its metabolites) were analyzed in a variety of biotic samples from the Salton Sea and the Imperial Valley (table 19). Concentrations of 19 (79 percent) of 24 organochlorine compounds were greater than reporting limits in at least one sample. Two of the compounds, toxaphene and hexachlorobenzene, were detected at concentrations greater than $1 \mu \mathrm{g} / \mathrm{g}$ wet weight. The two most frequently detected organochlorine pesticides were dieldrin (60.2 percent of samples), and DCPA (dacthal®) (63.6 percent of samples). Other compounds detected at concentrations greater than $0.1 \mu \mathrm{g} / \mathrm{g}$ include oxychlordane, trans-nonachlor, beta-hexachlorohexane (beta-BHC), and alpha-chlordane. This concentration $(0.1 \mu \mathrm{g} / \mathrm{g})$ is above the $0.05 \mu \mathrm{g} / \mathrm{g}$ threshold (National
Academy of Sciences, National Academy of Engineering, 1973) to protect fish-eating birds and mammals in marine ecosystems.

Toxaphene, a broad-spectrum insecticide, was one of the most heavily used agricultural chemicals on a global scale. It is extremely persistent in soil and water, with a documented half-life as great as 11 years (Eisler and Jacknow, 1985). The highest concentration of toxaphene in this study, $7.0 \mu \mathrm{g} / \mathrm{g}$ wet weight, was from a composite of Asiatic river clams collected from the Vail Cutoff Drain; this drain receives considerable subsurface drainwater flow. The only other toxaphene detected in clams was 1.1 $\mu \mathrm{g} / \mathrm{g}$ wet weight at Johnson Drain in the Coachella Valley. Because Asiatic river clams are nonmobile and benthic, they are excellent bioindicators of pesticide input to the environment.

Six spiny softshell turtles taken from the Vail Drain and from the Hazard Unit of the Salton Sea NWR had accumulated toxaphene in fat at concentrations as high as $6.2 \mu \mathrm{g} / \mathrm{g}$ wet weight, which 
indicates that toxaphene usage has been high in agricultural areas in the Vail drainage system. Toxaphene was banned for any use after 1986 (U.S. Environmental Protection Agency, 1982) in the United States; therefore, the documented concentrations in biota most likely are a result of past use.

All six turtles had significant concentrations of toxaphene (greater than $2.3 \mu \mathrm{g} / \mathrm{g}$ wet weight) in their fat, and one female had $1.0 \mu \mathrm{g} / \mathrm{g}$ wet weight in her eggs. These concentrations are higher than those reported by Hall (1980) for softshell turtles, but considerably lower than the $15.4 \mu \mathrm{g} / \mathrm{g}$ wet weight (assuming 90 percent moisture) found in painted turtles (Chrysemys picta) killed by toxaphene (Finley, 1960).

Toxaphene (as do many other organochlorine pesticides) accumulates in fat and may be safely stored by reptiles in the relatively isolated fat bodies (Hall, 1980). However, during periods of increased fat metabolism, such as reproduction, contaminants may be mobilized to other tissues such as eggs or, more critically, to the brain.

Toxaphene also was found in black-necked stilt eggs, ranging from less than the reporting limit $(0.01$ $\mu \mathrm{g} / \mathrm{g}$ wet weight) to $1.0 \mu \mathrm{g} / \mathrm{g}$. Toxaphene has been shown to cause severe embryotoxic effects, such as dislocated joints and poor growth in mallard ducklings, when used at application rates in excess of 1.12 $\mathrm{kg} / \mathrm{ha}$ (Hoffman and Eastin, 1982). No gross abnormalities were found in Salton Sea black-necked stilt chicks that might be attributable to toxaphene. Although reduced growth (in comparison with birds from a coastal nonagricultural area) was found, its cause had not been determined.

Hexachlorobenzene (HCB) residue in soil has become widespread throughout the environment (Zell and Ballschmiter, 1980) because of the extensive use of HCB as a fungicide and because it is a byproduct of the production of other chlorinated hydrocarbons (Villanueva and others, 1974). In spite of the fact that commercial production of HCB in the United States was discontinued in 1976, waste byproducts have continued to represent a significant source of contamination (U.S. Environmental Protection Agency, 1980b).

In the Imperial Valley, HCB has been detected in fish at concentrations near the $0.05 \mu \mathrm{g} / \mathrm{g}$ wet weight recommended threshold (National Academy of Sciences, National Academy of Engineering, 1973) to protect fish-eating birds and mammals and in pintails wintering at the Salton Sea (Ohlendorf and Miller, 1984; and Mora and others, 1987). However, HCB concentrations in white-faced ibis (geometric mean, $0.7 \mu \mathrm{g} / \mathrm{g}$ wet weight in liver; and geometric mean, 1.1 $\mu \mathrm{g} / \mathrm{g}$ wet weight in muscle), and a barn owl $(1.3 \mu \mathrm{g} / \mathrm{g}$ wet weight) from this study are considerably higher than any previously reported HCB concentrations from the Imperial Valley. The highest concentration of $2.9 \mu \mathrm{g} / \mathrm{g}$ wet weight found in ibis liver is about one-half that found in Japanese quail liver after being fed contaminated food $(5 \mu \mathrm{g} / \mathrm{g}$ ) for 90 days (Vos, 1971). It is not known how much HCB has been contributed to the Imperial Valley either as a result of agricultural activities, including irrigation and drainage practices, or contamination from other sources such as industrial waste byproducts.

Dieldrin historically has been used in agriculture to control pests on corn and citrus crops. Currently, in the United States, it is used only for subsurface soil injection to control termites (U.S. Environmental Protection Agency, 1980c). Although dieldrin and aldrin (the source of most environmental dieldrin residue) have not been used in the Imperial Valley as pesticides since 1975 , more than 60 percent of all biological samples collected for this study had detectable quantities of dieldrin (table 19). This high rate of detection is attributable, in part, to the fact that dieldrin is the most stable member of the chlorinated cyclodiene insecticides (Matsumura and Bousch, 1967) and, therefore, is very persistent in the environment. The National Contaminant Biomonitoring Program (Schmitt and others, 1990) has not documented any appreciable changes in dieldrin concentrations in fish from the Great Lakes and major rivers of the Midwest from 1978-79 to 1984. This persistence indicates that dieldrin residues in agricultural soil represent a continuing long-term potential threat to fish and wildlife.

In spite of the persistence of dieldrin and the high rate of detection, the geometric mean concentration in fish collected in the Imperial Valley for this study was less than the $0.005 \mu \mathrm{g} / \mathrm{g}$ wet weight threshold for the protection of fish-eating birds and mammals (National Academy of Sciences, National Academy of Engineering, 1973). However, recent CTSMP results indicated that mosquitofish from the Warren Drain of the Imperial Valley had dieldrin concentrations $(0.14$ $\mu \mathrm{g} / \mathrm{g}$ wet weight) well above this threshold (California Environmental Protection Agency, 1991). Thus, dieldrin concentrations at local "hot spots" such as the Warren Drain pose a significant threat for fish-eating birds, especially the great egret and other sensitive species (Faber and others, 1972), that nest at the Salton Sea. 
Other food items in the Imperial Valley such as pileworms, waterboatmen, and frogs had either nondetectable or very low dieldrin concentrations. In contrast, concentrations in fat of spiny softshell turtles were high $(0.85 \mu \mathrm{g} / \mathrm{g}$ wet weight $)$, as expected: Because dieldrin is nonpolar, it is lipophilic and bioaccumulates in fatty tissue (Heath and Vandekar, 1964). The highest observed concentration in the Imperial Valley was well below concentrations associated with residues found in turtles killed as a result of field applications of dieldrin (Hall, 1980). It is not known if the Imperial Valley concentrations are high enough to cause sublethal or chronic effects.

Generally, dieldrin concentrations in birds were low (less than $0.1 \mu \mathrm{g} / \mathrm{g}$ wet weight) except for blacknecked stilt, white-faced ibis, and great blue heron. The highest concentration $(0.33 \mu \mathrm{g} / \mathrm{g}$ wet weight $)$ was found in a black-necked stilt. Dieldrin concentrations from northern shovelers (nondetectable to $0.02 \mu \mathrm{g} / \mathrm{g}$ wet weight) and ruddy ducks (nondetectable to 0.02 $\mu \mathrm{g} / \mathrm{g}$ wet weight) were comparable to concentrations in waterfowl collected in 1981-82 from the Imperial Valley by Ohlendorf and Miller (1984) and Mora and others (1987). Pintails sampled from the Salton Sea in autumn 1981 by Ohlendorf and Miller (1984) had no detectable dieldrin, but those collected a few months later in December and January, had concentrations of 0.02 and $0.06 \mu \mathrm{g} / \mathrm{g}$ wet weight for males and females, respectively. These concentrations indicate that the pintails accumulated dieldrin while wintering at the Salton Sea.

White-faced ibis, which feed in agricultural fields, had detectable dieldrin concentrations (ranging from 0.02 to $0.22 \mu \mathrm{g} / \mathrm{g}$ wet weight) in all 18 samples collected. This 100-percent detection rate probably reflects the fact that dieldrin is very persistent in the soil at the point of its application where it can be transferred to earthworms and other soil invertebrates fed on by ibis.

The only bird eggs sampled from the Imperial Valley were from black-necked stilts. Stilts, which are primarily resident birds, likely accumulate dieldrin locally; 80 percent of the 122 eggs analyzed had detectable residues. It is not known what effect these residues (concentrations were as high as $0.15 \mu \mathrm{g} / \mathrm{g}$ wet weight), might have. However, dieldrin has been shown to be substantially more toxic to wildlife than are other organochlorine pesticides (Tucker and Crabtree, 1970).

Dieldrin was documented to be widespread in biological tissue, at low levels, throughout the Imperial Valley. Residues from birds sampled in this study are below levels known to have detrimental ef- fects (Stickel and others, 1969). However, as discussed earlier, in local areas such as Warren Drain, dieldrin concentrations in fish are high enough to pose a potential threat to sensitive species.

\section{ASSESSMENT OF SUSCEPTIBILITY OF BIRDS TO CONTAMINANT EFFECTS}

On the basis of a thorough assessment of available data from the Imperial Valley and the Salton Sea, the agriculture-related contaminants posing the most significant threats to wildlife are selenium, boron, and DDE.

In the preceding sections of this report, effects of contamination are evaluated only for those bird species that were sampled in this study. However, the number of species sampled is only a small fraction of the total number of species present in the study area. Therefore, a supplemental analysis was made for selected additional bird species of the Imperial Valley. Existing information-including documented toxicity thresholds, food habits, feeding strategy, and contaminant exposure-was used in this analysis. Rare, erratic, and accidental species (except endangered species) were not included in the analysis. Also not included are those species for which data were insufficient to determine contaminant effects.

An initial screening of the 375 documented bird species in the Imperial Valley showed that 127 could be subjected to actual or potential adverse effects related to drainwater. Information on status, feeding habits, population estimates, and food items for each species was compiled from reports by the U.S. Fish and Wildlife Service (1987) and the Salton Sea NWR (U.S. Fish and Wildlife Service, oral and written commun., 1990).

A further assessment was made to determine a "level of concern" for each of the 127 species. A high concern was assigned if the contaminant concentration in a major food item of a species was greater than any documented threshold as presented in previous sections of this report. A low concern was assigned if a major food item had a contaminant concentration less than a threshold but above analytical reporting limits, or if a minor food item had a contaminant concentration above a threshold. No concern was assigned if contaminant concentrations in all or most food items were at or near "background" concentrations. Results from this analysis, which are presented in table 20 , show that 92 species actually or potentially are exposed to elevated levels of agriculture-related contaminants and increased risk of adverse effects. 


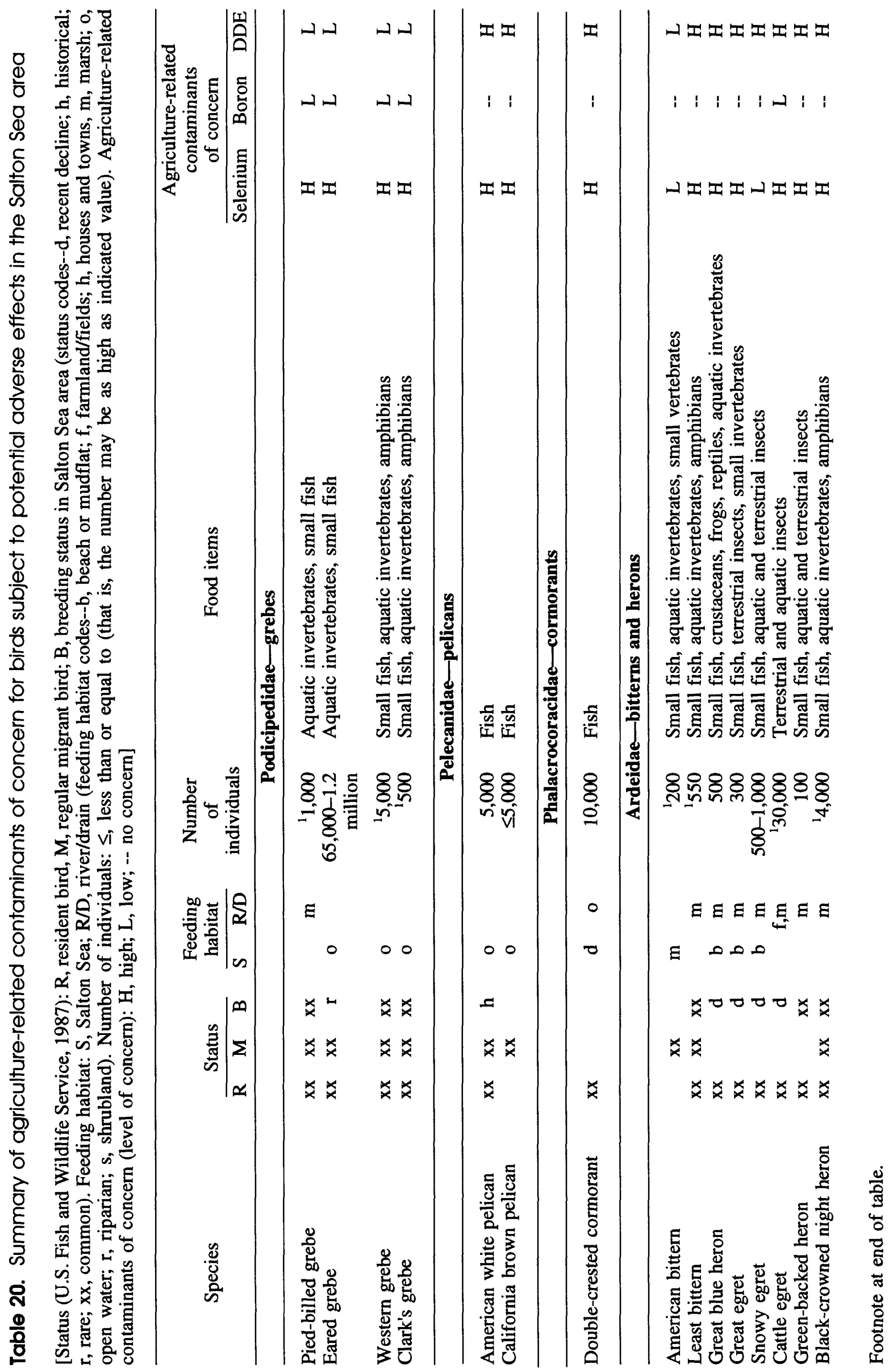




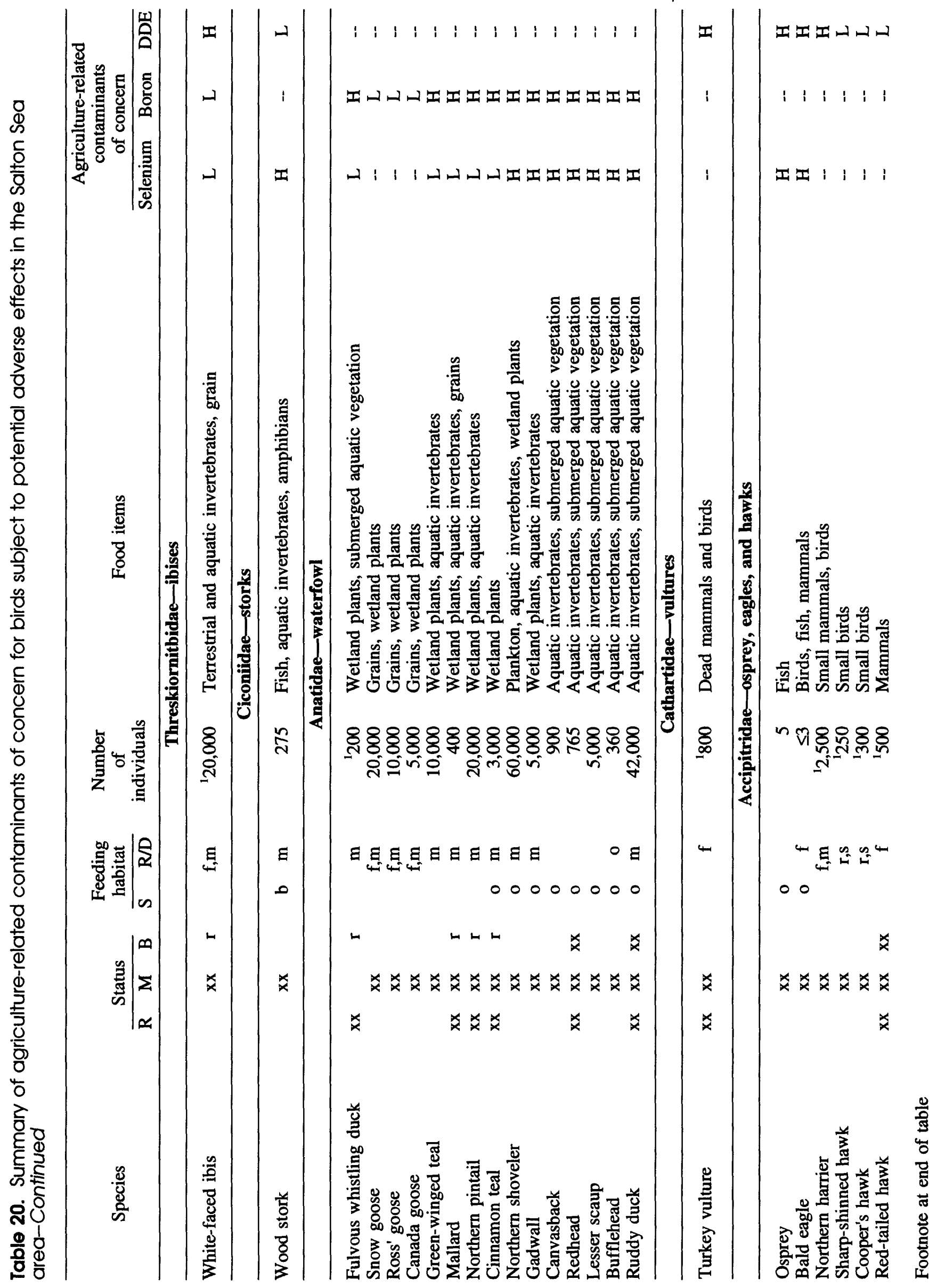




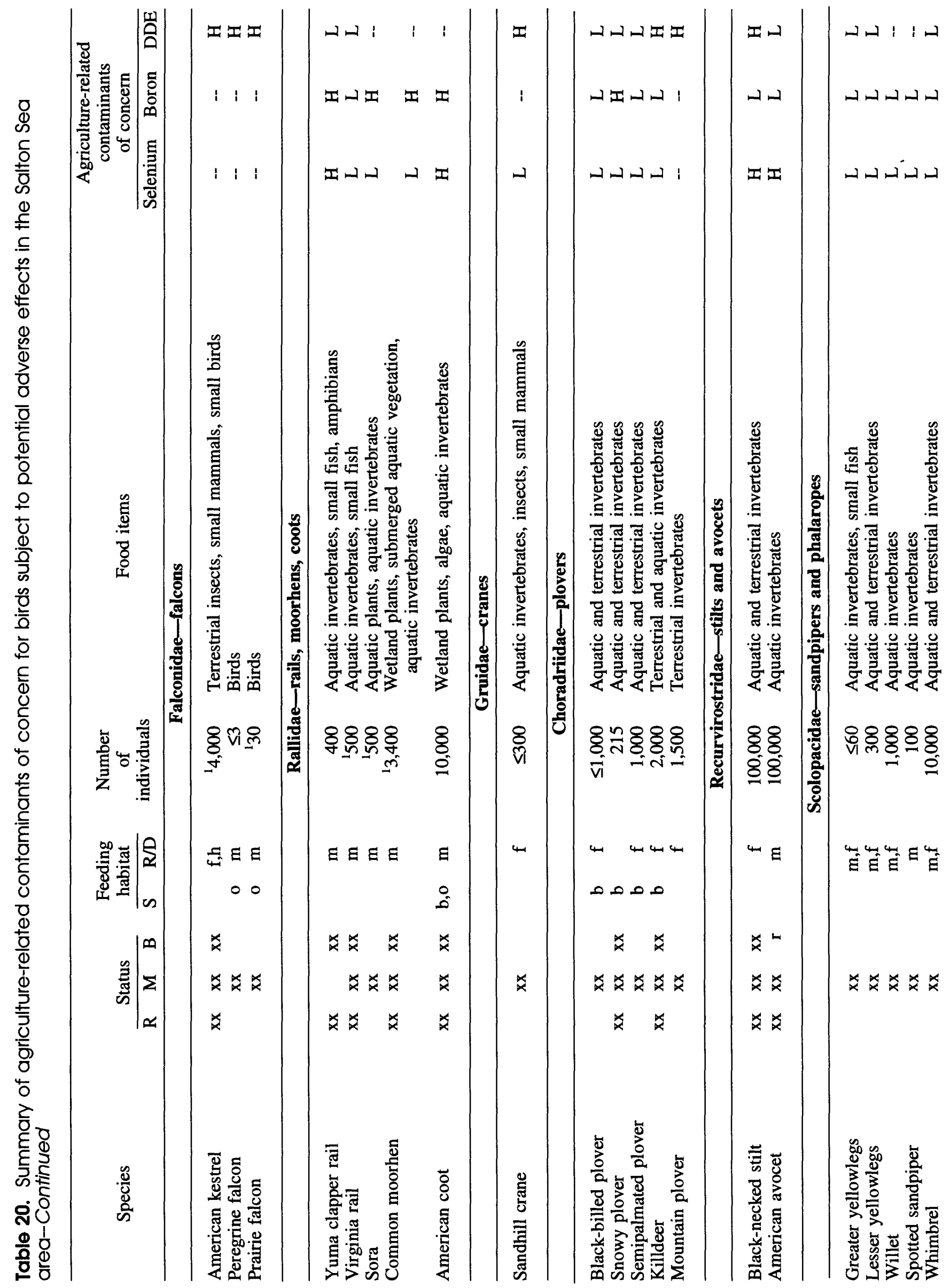




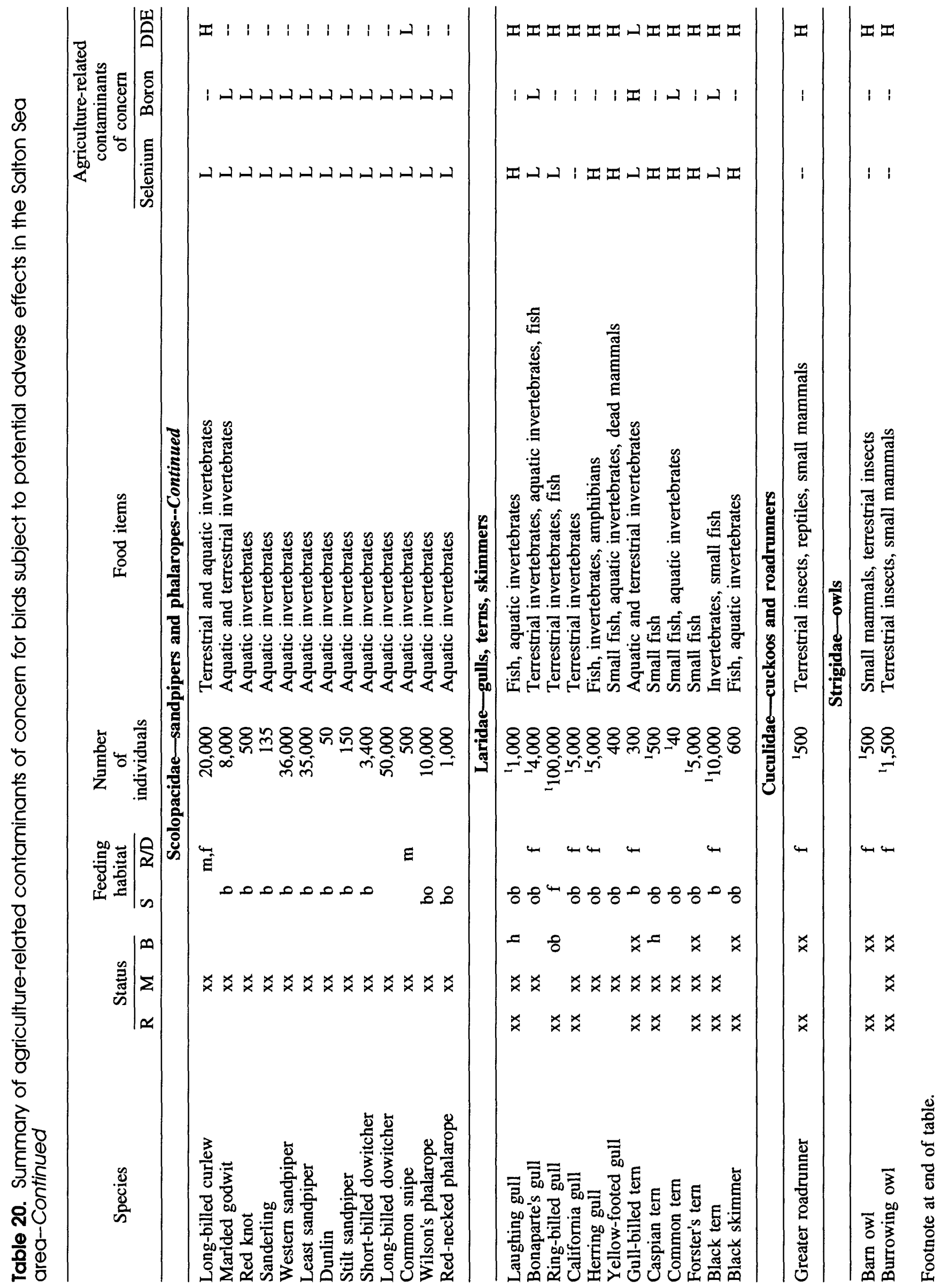




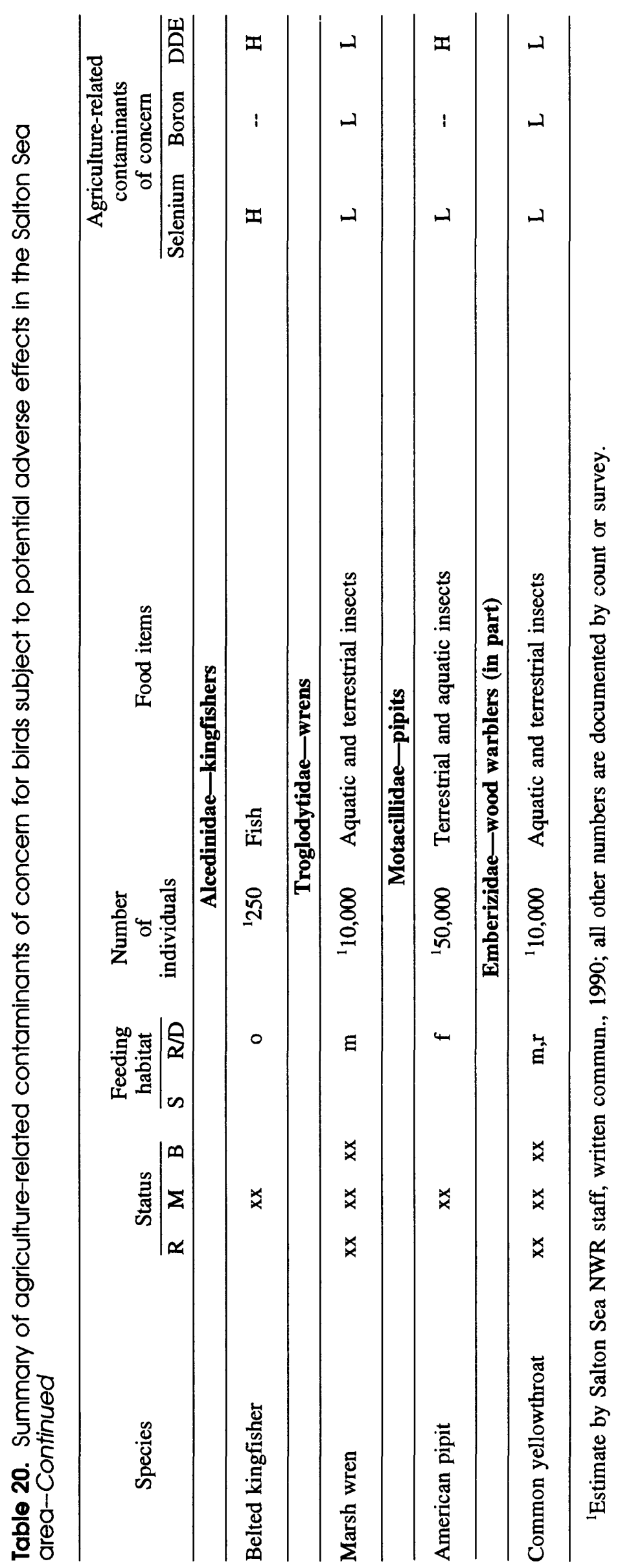

92 Water Quailty, Bottom Sediment, and Blota Associated with irrigation Drainage in the Salton Sea Area, Cailfornia 
Table 21. Number of bird species, by category, in the Salton Sea area actually or potentially adversely affected by selenium, boron, or DDE

[Number before diagonal is number of bird species actually or potentially adversely affected. Number after diagonal is total number of bird species in category]

\begin{tabular}{lrrr}
\hline \multirow{2}{*}{ Category } & \multicolumn{3}{c}{ Drainwater contaminant } \\
\cline { 2 - 4 } & Selenium & Boron & \multicolumn{1}{c}{ DDE } \\
\hline Resident & $35 / 42$ & $23 / 42$ & $34 / 42$ \\
Migratory & $68 / 82$ & $53 / 82$ & $51 / 82$ \\
Federally endangered & $3 / 4$ & $1 / 4$ & $4 / 4$ \\
\hline
\end{tabular}

A summary of the number of species (by category) in the Salton Sea area actually or potentially adversely affected by selenium, boron, or DDE is given in table 21. Overall, selenium is a concern for the greatest number of species and DDE is an especially high concern for endangered species. Selenium effects primarily are aquatic based, and the level of concern is greatest for higher-trophic-level species. The effects of selenium on terrestrial-feeding birds of prey such as the red-tailed hawk and prairie falcon are of little or no concern. Boron effects are a concern primarily for migratory waterfowl and shorebirds, as well as a few birds of prey, fish-eating birds, and many terrestrial feeders. DDE effects for most migratory waterfowl and shorebirds (mainly sandpipers) are of little concern.

In summary, the groups at greatest risk (in order of highest to lowest concern), are (1) fish-eating birds - for which there is a high level of concern for effects of selenium, primarily in the Salton Sea, and DDE throughout all aquatic habitats in the Imperial Valley; (2) waterfowl-for which levels of concern are high for selenium and boron in aquatic habitats; (3) shorebirds-for which levels of concern are variable for selenium and boron in all aquatic habitats and DDE in rivers and drains; and (4) terrestrial birds-for which levels of concern are high for DDE.

\section{SUMMARY AND CONCLUSIONS}

The factors controlling contaminant concentrations in subsurface drainwater in the study area are soil characteristics, hydrology, and agricultural practices. Although no spatial pattern is apparent for the distribution of specific conductance, or of dissolvedsolids, selenium, or boron concentrations in the Imperial Valley, higher concentrations of dissolved constituents commonly are associated with clayey soils. Low infiltration rates in these soils result in increased evaporation and, thus, increased evaporative concentration. These areas of high concentration generally are near the Salton Sea, which is the main topographic depression in the area, although high concentrations also occur in other areas throughout the Imperial Valley. Mesquite Lake, one of these areas of high concentrations, is a localized topographic depression near the city of El Centro.

Regression of hydrogen and oxygen stable-isotope ratios $\left(r^{2}=0.96, \alpha<0.01\right)$ in samples collected from sumps demonstrates that Colorado River water is the sole source of subsurface drainwater in the Imperial Valley. These results, along with concentration data, also indicate that evaporation is the main process controlling dissolved-solids concentration in subsurface drainwater. Further regression analysis shows that concentrations of chloride, boron, and selenium, as well as dissolved solids, in subsurface drainwater also can be attributed to evaporative concentration of Colorado River water.

Element weight ratios of selenium to chloride demonstrate that selenium detected in subsurface drainwater throughout the Imperial Valley originates from the Colorado River. The median $\mathrm{Se} / \mathrm{Cl}$ ratio for subsurface drainwater is similar to the ratio in Colorado River water in the East Highline Canal. Variations in the $\mathrm{Se} / \mathrm{Cl}$ ratio provide indications of either sources or sinks of selenium. In the area bordering the southern end of the Salton Sea, these ratios are significantly lower than in other parts of the Imperial Valley. These lower $\mathrm{Se} / \mathrm{Cl}$ ratios indicate that selenium is being removed from the water and possibly adsorbed to the sediments. This process occurs under reducing conditions such as are present along the southern border of the Salton Sea. Coupled with the presence of reducing conditions, lowselenium and high-chloride.water from the Salton Sea also may influence subsurface drainwater, thus affecting the $\mathrm{Se} / \mathrm{Cl}$ ratios. The Salton Sea is an excellent example of a selenium sink: The $\mathrm{Se} / \mathrm{Cl}$ ratio in the Salton Sea is several orders of magnitude lower than the $\mathrm{Se} / \mathrm{Cl}$ ratio in the fields of the Imperial Valley. Selenium in the inflowing water to the Salton Sea is selectively removed. A likely mechanism of removal, on the basis of published findings from laboratory and field studies in other areas, is concentration of elemental selenium in bottom sediment by selenate-respiring bacteria. No apparent spatial pattern was discerned in the distribution of selenium in the bottom sediment of the Salton Sea in the area adjacent to the Alamo River.

Ground-water samples collected from multipledepth wells and lysimeters at three sites (northern, 
middle, and southern) in the Imperial Valley indicated that depth of infiltration and amount of evaporative concentration varied according to soil type. Analysis of tritium concentrations in these shallow wells and lysimeters indicated that clayey soils, in comparison with sandy soils, significantly retarded the movement of irrigation water through the soil profile. Water at depth in these clayey fields had elevated dissolvedsolids concentrations.

Selenium-loading to the Salton Sea, calculated using the median selenium concentrations in subsurface drainwater and in the Alamo River at the outlet, indicates that about three-fourths of the discharge to the Salton Sea is water (essentially, Colorado River water acting as a diluent) that has very low selenium and dissolved-solids concentrations, and that about one-fourth of the discharge is drainwater (evaporatively concentrated Colorado River water) that has higher selenium concentrations. The low selenium and dissolved-solids water consists of tailwater runoff, rapid-percolation irrigation water, and possibly canal seepage. The estimated annual selenium load discharged to the Salton Sea by the Alamo River is about 6.5 tons, and the boron load is about 460 tons.

Time-series analysis of selenium concentration in subsurface drainwater indicated that the concentration generally varied inversely with volume of flow from individual sumps. For the entire data set, selenium concentrations in May 1986 were similar to selenium concentrations in May 1988 (slope nearly 1.0; $\left.r^{2}=0.785, \alpha<0.01\right)$. Subsurface-drainwater concentrations that were high in 1986 also were high in 1988 , and those that were low remained low.

Drainwater and agriculture-related contaminants, including selenium, boron, and DDE, were found to bioaccumulate in migratory and resident birds in the Imperial Valley. These contaminants are incorporated in bird tissue through the consumption of food. On the basis of in situ bioaccumulation tests in transplanted clams, levels and inputs of selenium, boron, and DDE fluctuated seasonally. Temporal variation in boron concentrations also occurred in ruddy ducks collected during the wintering period at the Salton Sea. In both cases, elevated contaminant concentrations were related to increased drainwater inflow during late winter and early spring agricultural activities.

Synergistic effects of these contaminants in birds were not evaluated because of their complexity. Results of other studies indicate that interactions of selenium and boron with other contaminants may occur. It could not be determined during this study if these contaminants acted synergistically or antagonistically in birds from the Imperial Valley.

Selenium bioaccumulated in food chains at the Salton Sea and in freshwater habitats in the Imperial Valley. A strong relation between higher selenium concentrations and higher trophic levels was found. Also, selenium concentrations were higher in saltwater food chains, at comparable trophic levels, than in freshwater food chains. This increased saltwater bioaccumulation puts fish-eating birds feeding in the Salton Sea at the greatest risk of selenium toxicity. Of resident Salton Sea birds, the double-crested cormorant had the highest liver selenium concentrations (42 $\mu \mathrm{g} / \mathrm{g}$ dry weight) in this study. This species recently has experienced a complete reproductive failure at the Salton Sea: The number of active nests declined from 63 in 1987 to 0 in 1991.

Waterfowl that consume food items containing more than $4 \mu \mathrm{g} / \mathrm{g}$ dry weight of selenium also are at risk. Northern shovelers, which accumulated selenium while wintering in the Imperial Valley, had the highest liver selenium concentrations (as great as $47 \mu \mathrm{g} / \mathrm{g}$ dry weight) of freshwater species collected. Birds with liver selenium concentrations greater than $30 \mu \mathrm{g} / \mathrm{g}$ dry weight are at high risk for reproductive effects. Eared grebes also are at significant risk from selenium toxicity: Concentrations in 60 percent of the liver samples were above the reproductive threshold.

Black-necked stilts, which are resident shorebirds in the Imperial Valley, were exposed to levels of selenium in food items as great as $12 \mu \mathrm{g} / \mathrm{g}$ dry weight (in pileworms). These levels are sufficient to cause a risk of embryotoxicity in 5 percent of the eggs. Selenium concentrations in eggs indicate that the probability of embryotoxicity in some eggs is greater than 20 percent. For the highest concentration of $35 \mu \mathrm{g} / \mathrm{g}$, the probability of embryotoxicity is greater than 60 percent.

Asiatic river clams placed in the Trifolium Drain, a major irrigation drain in the Imperial Valley, bioaccumulated selenium to $7.5 \mu \mathrm{g} / \mathrm{g}$ dry weight (greater than a 25-percent increase) during increased irrigation for late winter and early spring planting. Indigenous clams accumulated selenium in proportion to the inflow of irrigation drainwater, indicating that they can serve as excellent biomonitors.

Mosquitofish from the Trifolium Drain bioaccumulated selenium to 30 percent above the $12 \mu \mathrm{g} / \mathrm{g}$ dry weight reproductive threshold. Such bioaccumulation also may be occurring in other species not 
sampled in this study, including the endangered desert pupfish. Cephalic deformities documented in other studies of Salton Sea ichthyoplankton may be partially or fully caused by selenium and (or) other contaminants.

Boron was found to bioaccumulate at most trophic levels in aquatic ecosystems of the Imperial Valley. Boron concentrations in biota generally were higher in the Salton Sea (saltwater) species than in freshwater species collected in rivers and drains. Sampling in areas minimally affected by agricultural drainwater indicated that minor local boron sources exist in the Salton Sea drainage. Aquatic vegetation and invertebrates in the Imperial Valley had the highest concentrations of boron (as high as $390 \mu \mathrm{g} / \mathrm{g}$ dry weight) in this study. Benthic invertebrates had higher boron concentrations (geometric mean $70.2 \mu \mathrm{g} / \mathrm{g}$ dry weight) than did planktonic invertebrates (13.4 $\mu \mathrm{g} / \mathrm{g}$ dry weight). Migratory waterfowl may be experiencing chronic reproductive effects such as reduction of weight gain in ducklings and reduced hatchling weight as a result of consuming food items containing more than $35 \mu \mathrm{g} / \mathrm{g}$ dry weight of boron.

Resident shorebirds (black-necked stilts) bioaccumulated less boron than migratory waterfowl; however, there is adequate accumulation to cause reduced weight gain in the young. Growth rates of black-necked stilt young at the Salton Sea in 1989 were significantly lower than growth rates of stilts from a site (Bolsa Chica Ecological Reserve, in Orange County) not affected by agricultural drainwater. It is possible, however, that other variables are fully or partially responsible for the observed reduced growth rate.

Organochlorine pesticide residues are mobilized by tailwater runoff and (or) by resuspension of sediment in the rivers and surface drains flowing into the Salton Sea. Elevated concentrations of DDE (as high as $21 \mu \mathrm{g} / \mathrm{g}$ wet weight), toxaphene, and dieldrin were found mainly in higher-trophic-level species such as spiny softshell turtle, fish-eating birds, and birds of prey.

DDE was found in 99 percent of all samples analyzed, and the concentrations in biota were correlated with trophic level; that is, the highest concentrations were in organisms at higher feeding strata in food chains. Species associated with freshwater (rivers and drains) had concentrations that were higher than concentrations in species collected from the Salton Sea. Some of the highest concentrations $(11 \mu \mathrm{g} / \mathrm{g}$ wet weight) were found in white-faced ibis that fed in agricultural fields, consuming mostly invertebrates.
Resident species of birds in the Imperial Valley have likely experienced reproductive impairment as a result of DDE contamination: The number of active nests of cattle egrets declined from more than 2,000 in 1986 to 25 in 1991 (a decline of 99 percent), and a 17-percent thinning in great egret eggs was documented. In black-necked stilts, 7-percent eggshell thinning occurred. In addition, waterfowl and resident birds consume food that may exceed the 2.8 to $3.0 \mu \mathrm{g} / \mathrm{g}$ DDE wet weight dietary intake range shown to have adverse effects on waterfowl, as well as National Academy of Sciences guidelines for fisheating birds and predators $(1.0 \mu \mathrm{g} / \mathrm{g}$ wet weight, freshwater species; $0.05 \mu \mathrm{g} / \mathrm{g}$ wet weight, saltwater species). Birds of prey and fish-eating birds such as the endangered California brown pelican are at greatest risk of eggshell thinning as a result of DDE bioaccumulation. As already noted, double-crested cormorants have recently experienced a complete reproductive failure. Other birds, such as white-faced ibis, that feed in agricultural fields also may be at risk.

Measured DDE concentrations in biota collected as part of this and other studies done in the Imperial Valley are some of the highest concentrations documented in California. On the basis of DDE/DDT ratios and DDT/DDE/DDD proportions, these high concentrations resulted from historical rather than recent DDT use.

A total of 19 organochlorine pesticides other than DDT and its metabolites were found in biota from the Imperial Valley. Of these, only toxaphene and hexachlorobenzene, were detected at concentrations above $1 \mu \mathrm{g} / \mathrm{g}$ dry weight. The most frequently detected organochlorine pesticide residues were dieldrin in 60 percent of samples and DCPA in 64 percent. A dieldrin concentration of $0.14 \mu \mathrm{g} / \mathrm{g}$ wet weight in mosquitofish from Warren Drain was well above the $0.005 \mu \mathrm{g} / \mathrm{g}$ wet weight threshold for protection of fish-eating birds and mammals. Dieldrin concentrations at local "hot spots" such as Warren Drain pose a threat to birds that feed on mosquitofish.

\section{Selected References}

Adams, F.S., Cole, H., and Massie, L.B., 1973, Element constitution of selected aquatic vascular plants from Pennsylvania--submerged and floating leaved species and rooted emergent species: Environmental Pollution, v. 5 , p. 117-147.

Ahlrichs, J.S., and Hossner, L.T., 1987, Selenate and selenite mobility in overburden by saturated flow: Journal of Environmental Quality, v. 16, p. 95-98. 
Albers, P.H., Sileo, L., and Mulhern, B.M., 1986, Effects of environmental contaminants on snapping turtles of a tidal wetland: Archives of Environmental Contamination and Toxicology, v. 15, p. 39-49.

Anderson, D.W., Risebrough, R.W., Woods, L.A., DeWeese, L.R., and Edgecomb, W.G., 1975, Brown pelicans-improved reproduction of the southern California coast: Science, v. 190 , p. 806-808.

Andreasen, J.K., 1985, Insecticide resistance in mosquitofish of the lower Rio Grande Valley of Texas-an ecological hazard?: Archives of Environmental Contamination and Toxicology, v. 14, p. 573577.

Anita, N.J., and Cheng, J.Y., 1975, Culture studies on the effects from borate pollution on the growth of marine phytoplankters: Journal of Fisheries Resources Board of Canada, v. 32, p. 2487-2494.

Barnum, D.A., and Evliss, N.H., Jr., 1991, Impacts of changing irrigation practices on waterfowl habitat use in the southern San Joaquin Valley, California: California Department of Fish and Game, v. 77, no. 1, p. 10-21.

Barnum, D.A., and Gilmer, D.S., 1988, Selenium levels in biota from irrigation drainwater impoundments in the San Joaquin Valley, California: Lake and Reservoir Management, v. 4, no. 2, p. 181-186.

Bayly, I.A.E., 1991, On the concept and nature of athalassic (non-marine) saline waters: SALINET, issue no. 5, May 1991 , p. $76-80$.

Bellrose, F.C., 1976, Ducks, geese, and swans of North America: Harrisburg, Pa., Stackpole Books, 540 p.

Blus, L.J., 1982, Further interpretation of the relation of organochlorine residues in brown pelican eggs: Environmental Pollution, v. 28, p. 15-33.

Blus, L.J., Henny, C.J., and Kaiser, T.E., 1980, Pollution ecology of breeding great blue herons in the Columbia Basin, Oregon and Washington: Murrelet, v. 61, p. 6371.

Blus, L.J., Henny, C.J., Stafford, C.J., and Grove, R.A., 1987, Persistence of DDT and metabolites in wildlife from Washington State orchards: Archives of Environmental Contamination and Toxicology, v. 16, p. $467-476$.

Boellstorff, D.E., Ohlendorf, H.M., Anderson, D.W., O'Neill, E.J., Keith, J.O., and Prouty, R.M., 1985, Organochlorine chemical residues in white pelicans and western grebes from the Klamath Basin, California: Archives of Environmental Contamination and Toxicology, v. 14, p. 485-493.

Bottino, N.R., Banks, C.H., Irgolic, K.J., Micks, P., Wheeler, A.E., and Zingaro, R.A., 1984, Selenium containing amino acids and proteins in algae: Phytochemistry, v. 23, no. 11, p. 2445-2452.

Bowers, J.C., McConaughy, C.E., Polinoski, K.G., and Smith, G.B., 1985, Water resources data-California, water year 1984. Volume 1. Southern Great Basin from Mexican border to Mono Lake basin, and Pacific slope basins from Tijuana River to Santa Maria River: U.S. Geological Survey Water-Data Report CA-84-1, 375 p.
Brook, E.J., and Moore, J.N., 1988, Particle-size and chemical control of $\mathrm{As}, \mathrm{Cd}, \mathrm{Cu}, \mathrm{Fe}, \mathrm{Mn}, \mathrm{Ni}, \mathrm{Pb}$, and $\mathrm{Zn}$ in bed sediment from the Clark Fork River, Montana (USA): Science for the Total Environment, v. 76, p. 247-266.

Brown, J.S., 1920, Routes to desert water places in the Salton Sea region, California: U.S. Geological Survey Water-Supply Paper 490-A, 86 p.

1923, The Salton Sea region, California: A geographic, geologic, and hydrologic reconnaissance with a guide to desert watering places: U.S. Geological Survey Water-Supply Paper 497, 292 p.

Bryant, V., McLusky, D.S., Roddie, K., and Newbery, D.M., 1984, Effect of temperature and salinity on the toxicity of chromium to three estuarine invertebrates. (Corophium volutator, Macoma balthica, Nereis diversicolor): Marine Ecology Progress Series, v. 20, p. 137-149.

Byer, W.N., and Krynitsky, A.J., 1989, Long-term persistence of dieldrin, DDT, and heptachlor epoxide in earthworms: Ambio, v. 18, no. 5, p. 271-273.

California Department of Fish and Game, 1987, DFG update of the Senate Natural Resources Committee's Subcommittee on environmental issues regarding the Salton Sea: Presented at Interim Hearing of the Natural Resources Committee's Subcommittee on Environmental Issues on July 23, 1987, Indio, California, by F. Worthley, California Department of Fish and Game.

California Environmental Protection Agency, 1991, Toxic Substances Monitoring Program 1988-1989: 91-1WQ, June 1991, 103 p. and appendixes.

California State Water Resources Control Board, 1990, Toxic Substances Monitoring Program, ten year summary report, 1978-1987: 90-1WQ, August 1990, $133 \mathrm{p}$. and appendixes.

California Toxic Substances Monitornng Program, 1983a, Synopsis of contaminant body burden levels in Alamo River (Imperial County) fishes, $18 \mathrm{p}$.

$1983 \mathrm{~b}$, Synopsis of contaminant body burden levels in New River (Imperial County) fishes, $15 \mathrm{p}$.

Clark, D.R., Jr., and Krynitsky, A.J., 1983, DDT-recent contamination in New Mexico and Arizona: Environment, v. 25, p. 27-31.

Cline, J.D., 1969, Spectrophotometric determination of hydrogen sulfide in natural water: Limnology and Oceanography, v. 14, p. 454.

Coleman, J.S., and Fraser, J.D., 1990, Age estimation and growth of black and turkey vultures: Journal of Field Ornithology, v. 60 , no. 2, p. 197-208.

Cooke, T.D., and Bruland, K.W., 1987, Aquatic chemistry of selenium: Evidence of biomethylation: Environmental Sciences and Technology, v. 21, no. 12, p. 1214-1219.

Coplen, T.B., 1976, Cooperative geochemical resource assessment of the Mesa geothermal system: Institute of Geophysics and Planetary Physics, University of California, Riverside, paper no. 76-1, 97 p.

Craig, Harmon, 1961, Isotopic variations in meteoric waters: Science, v. 113, p. 1702-1703. 
Craig, Harmon, 1966, Isotopic composition and origin of the Red Sea and Salton Sea geothermal brines: Science, v. 154, p. 1544-1548.

1969, Discussion of source fluids for Salton Sea geothermal system: American Journal of Science, v. 267, p. $249-255$.

Custer, T.W., Hensler, G.L., and Kaiser, T.E., 1983, Clutch size, reproductive success, and organochlorine contaminants in Atlantic coast black-crowned nightherons: Auk, v. 100, p. 699-710.

Custer, T.W., and Mitchell, C.A., 1987, Organochlorine contaminants and reproductive success of black skimmers in south Texas, 1984: Journal of Field Ornithology, v. 58 , no. 4 , p. $480-489$.

Cutter, G.A., 1982, Selenium in reducing waters: Science, v. 217 , p. $829-831$.

Deverel, S.J., and Fujii, Roger, 1987, Processes affecting the distribution of selenium in shallow ground water of agricultural areas, Western San Joaquin Valley, California: U.S. Geological Survey Open-File Report 87-220, $14 \mathrm{p}$.

Deverel, S.J., and Gallanthine, S.K., 1989, Relation of salinity and selenium in shallow ground water to hydrologic and geochemical processes, Western San Joaquin Valley, California: Journal of Hydrology, v. 109 , no. $1-2$, p. $125-149$.

Deverel, S.J., and Millard, S.P., 1988, Distribution and mobility of selenium and other trace elements in shallow ground water of the western San Joaquin Valley, California: Environmental Science and Technology, v. 22, no. 6, p. 697-702.

Eccles, L.A., 1979, Pesticide residues in agricultural drains, southeastern desert area, California: U.S. Geological Survey Water-Resources Investigations Report 79-16, $60 \mathrm{p}$.

Eisler, Ronald, 1985, Selenium hazards to fish, wildlife, and invertebrates--a synoptic review: U.S. Fish and Wildlife Service, Biological Report 85(1.5), 57 p.

1990, Boron hazards to fish, wildlife, and invertebrates--a synoptic review: U.S. Fish and Wildlife Service, Biological Report 85(1.20), 32 p.

Eisler, Ronald, and Jacknow, J., 1985, Toxaphene hazards to fish, wildlife, and invertebrates--A synoptic review: U.S. Fish and Wildlife Service Biological Report 85(1.4), $26 \mathrm{p}$.

Ellis, D.H., DeWeese, L.R., Grubb, T.G., Kiff, L.F., Smith, D.G., Jarman, W.M., and Peakall, D.B., 1989, Pesticide residues in Arizona peregrine falcon eggs and prey: Bulletin of Environmental Contamination and Toxicology, v. 42, p. 57-64.

Elrashidi, M.A., Adriano, D.C., Workman, S.M., and Lindsay, W.L., 1987, Chemical equilibria of selenium in soils: A theoretical development: Soil Science, v. 144 , no. 2, p. 141-152.

Elrick, K.A., and Horowitz, A.J., 1985, Analysis of rocks and sediments for arsenic, antimony, and selenium, by wet digestion and hydride generation atomic absorption: U.S. Geological Survey Open-File Report 85-497, 14 p.

Epstein, S., and Mayeda, T., 1953, Variations of the ${ }^{18} \mathrm{O}$ content of waters from natural sources: Geochimica et Cosmochimica Acta, v. 4, p. 213-224.
Faber, R.A., Risebrough, R.W., and Pratt H.M., 1972, Organochlorines and mercury in common egrets and great blue herons: Environmental Pollution, v. 3, p. 111-122.

Finley, R.B., Jr., 1960, Direct and indirect effects of some insecticides on western wildlife: Proceedings of the Western Association of State Game and Fish Commissions, v. 40, p. 121-129.

Fishman, M.J., and Friedman, L.C., eds., 1989, Methods for determination of inorganic substances in water and fluvial sediments: U.S. Geological Survey Techniques of Water-Resources Investigations, Book 5, Chapter A1, $545 \mathrm{p}$.

Fitzner, R.E., Blus, L.J., Henny, C.J., and Carlile, D.W., 1988, Organochlorine residues in great blue herons from the northwestern United States: Colonial Waterbirds, v. 11 , no. 2 , p. 293-300.

Fleming, W.J., and Cain, B.W., 1985, Areas of localized organochlorine contamination in Arizona and New Mexico: Southwestern Naturalist, v. 30, p. 269-277.

Fontes, J.Ch, 1980, Environmental isotopes in groundwater hydrology in Handbook of Environmental Isotope Geochemistry, edited by P. Fritz and J.Ch. Fontes, v. 1, The Terrestrial Environment, A: New York, Elsevier Scientific, p. 75-1400.

Fox, G.A., 1976, Eggshell quality--its ecological and physiological significance in a DDE-contaminated common tern population: Wilson Bulletin, v. 88, p. $459-477$.

Friedman, L.C., and Erdmann, D.E., 1982, Quality assurance practices for the chemical and biological analyses of water and fluvial sediment: U.S. Geological Survey Techniques of Water-Resources Investigations, Book 5, chap. A6, $181 \mathrm{p}$.

Gersich, F.M., 1984, Evaluation of a static renewal chronic toxicity test method for Daphnia magna Straus using boric acid: Environmental Toxicology and Chemistry, v. 3, p. 89-94.

Grant, G.S., 1982, Avian incubation-egg temperature, nest humidity, and behavioral thermoregulation in a hot environment: Ornithological Monographs, no. 30,75 p.

Hagar, J., and Garcia, J., 1988, A review of the potential biological response to salinity changes in the Salton Sea: Sausalito, California, Biosystems Analysis, Inc.

Hall, R.J., 1980, Effects of environmental contaminants on reptiles--a review: U.S. Fish and Wildlife Service Special Scientific Report, Wildlife no. 228, 12 p.

Heath, D.F., and Vandekar, M., 1964, Toxicity and metabolism of dieldrin in rats: British Journal of Industrial Medicine, v. 21, p. 269, in U.S. EPA, 1980, Ambient water quality criteria for aldrin/dieldrin: EPA 440/5-80-019, $237 \mathrm{p}$.

Heath, R.G., Spann, J.W., and Kreitzer, J.F., 1969, Marked DDE impairment of mallard reproduction in controlled studies: Nature, v. 224, p. 47-78.

Heinz, G.H., Hoffman, D.J., and Gold, L.G., 1989, Impaired reproduction of mallards fed an organic form of selenium: Journal of Wildlife Management, v. 53, no. 2 , p. 418-428. 
Heinz, G.H., Hoffman, D.J., Krynitsky, A.J., and Weller, D.M.G., 1987, Reproduction in mallards fed selenium: Environmental Toxicology and Chemistry, v. 6, p. 423433.

Heinz, G.H., Pendelton, G.W., Krynitsky, A.J., and Gold, L.G., 1990, Selenium accumulation and elimination in mallards: Archives of Environmental Contamination and Toxicology, v. 19, p. 374-379.

Helgeson, H.C., 1968, Geologic and thermodynamic characteristics of the Salton Sea geothermal system: American Journal of Science, v. 266, p. 129-166

Hely, A.G., Hughes, G.H., and Irelan, Burdge, 1966, Hydrologic regimen of Salton Sea: U.S. Geological Survey Professional Paper 486-C, 32 p.

Henny, C.J., and Blus, L.J., 1986, Radiotelemetry locates wintering grounds of DDE-contaminated black-crowned night herons: Wildlife Society Bulletin, v. 14, p. 236241.

Henny, C.J., Blus, L.J., Krynitsky, A.J., and Bunck, C.M., 1984, Current impact of DDE on black-crowned night herons in the intermountain west: Journal of Wildlife Management, v. 48, no. 1, p. 1-13.

Henny, C.J., and Herron, G.B., 1989, DDE, Selenium, mercury, and white-faced ibis reproduction at Carson Lake, Nevada: Journal of Wildlife Management, v. 54, no. 4, p. 1032-1045.

Herald, E.S., 1949, Effects of DDT-oil solutions upon amphibians and reptiles: Herpetologica, v. 5, p. 117-120.

Hickey, J.J., and Anderson, D.W., 1968, Chlorinated hydrocarbons and eggshell changes in raptorial and fish-eating birds: Science, v. 162, p. 271-273.

Hoffman, D.J., Camardese, M.B., LeCaptain, L.J., and Pendleton, G.W., 1990, Effects of boron on growth and physiology in mallard ducklings: Environmental Toxicology and Chemistry, v. 9, p. 335-346.

Hoffman, D.J., and Eastin, W.C., Jr., 1982, Effects of lindane, paraquat, toxaphene, and 2,4,5-trichlorophenoxyacetic acid on mallard embryo development: Archives of Environmental Contamination and Toxicology, v. 11 , p. $79-86$.

Hoffman, D.J., Ohlendorf, H.M., and Aldrich, T.W., 1988, Selenium teratogenesis in natural populations of aquatic birds in central California: Archives of Environmental Contamination and Toxicology, v. 17, p. 519-525.

Hoffman, R.J., Hallock, R.J., Rowe, T.G., Lico, M.S., Burge, H.L., and Thompson, S.P., 1990, Reconnaissance investigation of water quality, bottom sediment, and biota associated with irrigation drainage in and near Stillwater Wildlife Management Area, Churchill County, Nevada, 1986-87: U.S. Geological Survey Water-Resources Investigations Report 89-4105, $150 \mathrm{p}$.

Hogg, N.D., 1973, Chlorinated hydrocarbon pesticide residues, Salton Sea, California: California State Polytechnic University, Pomona, unpublished M.S. thesis, $63 \mathrm{p}$.

Holmes, J.G., and others, 1903, Soil survey of the Imperial area, California: Field Operations of the Bureau of Soils, 1903, p. 1219-1246.
Hothem, R.L., and Ohlendorf, H.M., 1989, Contaminants in food of aquatic birds of Kesterson Reservoir, California, 1985: Archives of Environmental Contamination and Toxicology, v. 18, p. 773-786.

Hunt, W.G., Johnson, B.S., Thelnader, C.G., Walton, B.J., Risebrough, R.W., Jarman, W.M., Springer, A.M., Monk, T.G., and Walker W., II, 1986, Environmental levels of p,p'-DDE indicate multiple sources: Environmental Toxicology and Chemistry, v. 5, p. 2127.

Hwang, R.B., Luthin, J.N., and Taylor, G.S., 1974, Effect of backfill on drain flow in layered soils: American Society of Civil Engineers, Journal of Irrigation and Drainage Division, v. 100, no. IR3, p. 267-276.

Ingles, L.G., 1965, Mammals of the Pacific states: Stanford, California, Stanford University Press, 506 p.

Jenkins, D.W., 1980, Biological monitoring of toxic trace metals, Volume 2, Toxic trace metals in plants and animals of the world, Part I: Environmental Monitoring Systems Laboratory, Office of Research and Development, prepared for U.S. Environmental Protection Agency, p. 150-171.

Kay, S.H., 1984, Potential for biomagnification of contaminants within marine and freshwater food webs. Technical Report. D-84-7-U.S. Army Corps of Engineers, Washington, D.C.

Kendall, Carol, and Coplen, T.B., 1985, Multisample conversion of water to hydrogen by zinc for stable isotope determination: Analytical Chemistry, v. 57, p. 1437-1440.

King, K.A., 1989a, Food habits and organochlorine contaminants in the diet of olivaceous cormorants in Galveston Bay, Texas: The Southwestern Naturalist, v. 34, no. 3, p. 338-343.

$1989 \mathrm{~b}$, Food habits and organochlorine contaminants in the diet of black skimmers, Galveston Bay, Texas, USA: Colonial Waterbirds, v. 12, no. 1, p. 109-112.

King, K.A., Stafford, C.J., Cain, B.W., Mueller, A.J., and Hall, H.D., 1987, Industrial, agricultural, and petroleum contaminants in cormorants wintering near the Houston shipping channel, Texas, USA: Colonial Waterbirds, v. 10 , no. 1 , p. 93-99.

Klasing, S.A., and Pilch, S.M., 1988, Agricultural drainage water contamination in the San Joaquin Valley--a public health perspective for selenium, boron, and molybdenum: San Joaquin Valley Drainage Program, $135 \mathrm{p}$.

Koluvek, P.K., 1971, Design of tile drains in Imperial Valley: Paper No. 71-240, presented to American Society of Agricultural Engineers Annual Meeting, Pullman, Washington.

Koranda, J.D., Stuart, M., Thompson, S., and Conrado, C., 1979 , Biogeochemical studies of wintering waterfowl in the Imperial Valleys: Lawrence Livermore Laboratory report on Department of Energy contract W-7405-Eng48, UCID-18288, $119 \mathrm{p}$.

Kuhl, D.L., and Oglesby, L.C., 1979, Reproduction and survival of the pileworm Nereis succinea in higher Salton Sea salinities: Biological Bulletin, v. 157, p. 153-165. 
Lasker, R., Tenaza, R.H., and Chamberlain, L.L., 1972, The response of Salton Sea fish eggs and larvae to salinity stress: California Department of Fish and Game, v. 58, no. 1, p. 58-66.

Lemly, A.D., 1986, Effects of selenium on fish and other aquatic life, in Summers, J.B., and Anderson, S.S., eds., Toxic substances in agricultural water supply and drainage: defining the problem: U.S. Committee on Irrigation and Drainage, Denver, Colorado, $358 \mathrm{p}$.

Lemly, A.D., 1990, Agricultural irrigation drainwater studies, in support of the San Joaquin Valley drainage program: Final Report to National Fisheries Contaminant Research Center, Columbia, Missouri., p. 309.

Lemly, A.D., and Smith, G.J., 1987, Aquatic cycling of selenium--implications for fish and wildlife: U.S. Fish and Wildlife Service Wildlife Leaflet 12, $10 \mathrm{p}$.

Lewis, M.A., and Valentine, L.C., 1981, Acute and chronic toxicities of boric acid to Daphnia magna Straus: Bulletin of Environmental Contamination and Toxicology, v. 27, p. 309-315.

Loeltz, O.J., Irelan, Burdge, Robison, J.H., and Olmsted, F.H., 1975, Geohydrologic reconnaissance of the Imperial Valley: U.S. Geological Survey Professional Paper 486-K, 54 p.

Longcore, J.R., and Stendell, R.C., 1977, Shell thinning and reproductive impairment in black ducks after cessation of DDE dosage: Archives of Environmental Contamination and Toxicology, v. 6, p. 293-304.

Maas, E.V., 1986, Salt tolerance of plants: Applied Agricultural Research, v. 1, p. 12-16.

Margat, W., and Sell, J.L., 1979, Distribution of mercury and selenium in egg components and egg white protein: Proceedings of the Society of Experimental Biological Medicine, v. 161, p. 458-463.

Matsui, M.L., 1989, The geographical distribution and relative abundance of the eggs and larvae of three Salton Sea sport fish: Report to California Department Fish and Game, project number F-51-R-1, 11 p.

Matsumura, F., and Bousch, G.M., 1967, Dieldrin-degradation by soil microorganisms: Science, v. 156, p. 959-961.

May, R.C., 1976, Effects of Salton Sea water on the eggs and larvae of Bairdiella icistia (Pisces: Sciaenidae): California Fish and Game, v. 62, p. 119-131.

McCleneghan, K., Meinz, M., Crane, D., Seto, W., and Lew, T., 1981, Toxic substances monitoring program 1980: Water Quality Monitoring Report 81-8TS, California State Water Resources Control Board, $56 \mathrm{p}$.

McLane, M.A.R., and Hall, L.C., 1972, DDE thins screech owl eggshells: Bulletin of Environmental Contamination and Toxicology, v. 8, no. 2, p. 65-68.

Menzie, C.A., 1978, Metabolism of pesticides, update II: U.S. Fish and Wildlife Service Special Science Report, Wildlife no. $212,318 \mathrm{p}$.

Milne, L., and Milne, M., 1980, Insects and spiders: Alfred A. Knopf, Inc., New York, 989 p.

Moles, A., and Pella, J.J., 1984, Effects of parasitism and temperature on salinity tolerance of the kelp shrimp Eualus suckleyi: Transactions of the American Fisheries Society, v. 113, p. 354-359.
Mora, M.A., Anderson, D.W., and Mount, M.E., 1987, Seasonal variation of body condition and organochlorines in wild ducks from California and Mexico: Journal of Wildlife Management, v. 5, no. 1, p. 132140.

Morton, P.K., 1966, Geologic map of Imperial County, California, with gravity contours: California Division of Mines and Geology, Imperial County Report 7.

Muffler, L.J., and Doe, B.R., 1968, Composition and mean age of detritus of the Colorado River delta in the Salton Trough, southern California: Journal of Sedimentary Petrology, v. 38, p. 384-399.

Muffler, L.J., and White, D.E., 1968, Origin of $\mathrm{CO}_{2}$ in the Salton Sea geothermal system, southeastern California: USA, Proceedings of 23rd International Geological Congress, Prague, v. 97, p. 185-194.

National Academy of Sciences, National Academy of Engineering, 1973 [1974], Water quality criteria, 1972: U.S. Environmental Protection Agency Report, EPA R3-73-033, $594 \mathrm{p}$.

Naven, C.E., 1983, Compilation of legal limits for hazardous substances in fish and fishery products: Circular No. 764, FIRI/C764, Food and Agricultural Organization of the United Nations.

Neal, R.H., Sposito, G., Holtzclaw, K.M., and Traina, S.J., 1987, Selenite adsorption on alluvial soils: I. Soil composition and $\mathrm{pH}$ effects: Soil Science Society of America Journal, v. 51, p. 1161-1165.

Ogle, R.S., Maier, K.J., Kiffney, P., Williams, M.J., Brasher, A., Melton, L.A., and Knight A.W., 1988, Bioaccumulation of selenium in aquatic ecosystems: Lake and.Reservoir Management, v. 4, no. 2, p. 165173.

Ohlendorf, H.M., 1989, Bioaccumulation and effects of selenium in wildlife, in L.W. Jacobs (ed.), Selenium in agriculture and the environment: Special Publication No. 23, Soil Science of America, p. 133-177.

Ohlendorf, H.M., Hoffman, D.J., Saiki, M.K., and Aldrich, T.W., 1986a, Embryonic mortality and abnormalities of aquatic birds: Apparent impacts of selenium from irrigation drainwater: The Science of the Total Environment, v. 52 p. 49-63.

Ohlendorf, H.M., Hothem, R.L., and Aldrich, T.W., 1988, Bioaccumulation of selenium by snakes and frogs in the San Joaquin Valley, California: Copeia, v. 24, p. 704710.

Ohlendorf, H.M., Hothem, R.L., Aldrich, T.W., and Krynitsky, A.J., 1987, Selenium contamination of the grasslands, a major California waterfowl area: The Science of the Total Environment, v. 66, p. 169-183.

Ohlendorf, H.M., Hothem, R.L., Bunck, C.M., Aldrich, T.W., and Moore, J.F., 1986b, Relationships between selenium concentrations and avian reproduction: Transactions of the North American Wildlife Natural Resource Conference, v. 51, p. 330-342.

Ohlendorf, H.M., Kilness, A.W., Simmons, J.L., Stroud, R.K., Hoffman, D.J., and Moore, J.F., 1988, Selenium toxicosis in wild aquatic birds: Journal of Toxicology and Environmental Health, v. 24, p. 67-92. 
Ohlendorf, H.M., Klass, E.E., and Kaiser, T.E., 1979, Environmental pollutants and eggshell thickness-Anhingas and wading birds in Eastern United States: U.S. Fish and Wildlife Service Special Scientific Report, Wildlife no. 216.

Ohlendorf, H.M., and Marois, K.C., 1990, Organochlorines and selenium in California night-heron and egret eggs: Environmental Monitoring and Assessment, v. 15, p. 91-104.

Ohlendorf, H.M., and Miller, M.R., 1984, Organochlorine contaminants in California waterfowl: Journal of Wildlife Management, v. 48, no. 3, p. 867-877.

Ohlendorf, H.M., Risebrough, R.W., and Vermeer, Kees, 1978, Exposure of marine birds to environmental pollutants: U.S. Fish and Wildlife Service Research Report, no. 9, 40 p.

Ohlendorf, H.M., Schaffner, F.C., Custer, T.W., and Stafford, C.J., 1985, Reproduction and organochlorine contaminants in terns at San Diego Bay: Colonial Waterbirds, v. 8, p. 42-53.

Ohlendorf, H.M, and Skorupa, J.P., 1989, Selenium in relation to wildlife and agricultural drainage water, in Proceedings of the Fourth International Symposium on Uses of Selenium and Tellurium, Carapella, S.C., Jr., ed. Darien, Connecticutt, Selenium-Tellurium Development Association, Inc., 1989, p. 314-338.

Olafsson, P.G., Bryan, A.M., Bush, B., and Stone, W., 1983, Snapping turtles--a biological screen for PCBs: Chemosphere, v. 12, p. 1525-1532.

Oremland, R.S., Hollibaugh, J.T., Maest, A.S., Presser, T.S., Miller, L.G., and Culbertson, C.W., 1989, Selenate reduction to elemental selenium by anaerobic bacteria in sediments and culture: Biogeochemical significance of a novel, sulfate-independent respiration: Applied and Environmental Microbiology, v. 55, no. 9, p. 2333-2343.

Oremland, R.S., Steinberg, N.A, Maest, A.S., Miller, L.G., and Hollibaugh, J.T., 1990, Measurement of in situ rates of selenate removal by dissimilatory bacterial reduction in sediments: Environment Science and Technology, v. 24 , no. 8 , p. 1157-1166.

Ort, J.F., and Latshaw, J.D., 1978, The toxic level of sodium selenite in the diet of laying chickens: Journal of Nutrition, v. 108, p. 1114-1120.

Page, G.W., Stenzel, L.E., Kjelmyr, J.E., and Shuford, W.D., 1990, Shorebird numbers in wetlands of the Pacific Flyway--A summary of spring and fall counts in 1988 and 1989: Point Reyes Bird Observatory, Stinson Beach, California, $11 \mathrm{p}$.

Pearce, P.A., Peakall, D.B., and Reynolds, L.M., 1979, Shell thinning and residues of organochlorines and mercury in seabird eggs, eastern Canada, 1970-1976: Pesticides Monitoring Journal, v. 13, p. 61-68.

Pimental, David, 1971, Ecological effects of pesticides on non-target species: Executive Office of the President, Office of Science and Technology, p. 16-28.

Platter, M.F., 1976, Breeding ecology of cattle egrets and snowy egrets at the Salton Sea, southern California: San Diego State University, unpublished M.S. thesis, $122 \mathrm{p}$.
Presser, T.S., and Ohlendorf, H.M., 1987, Biogeochemical cycling of selenium in the San Joaquin Valley, California U.S.A.: Environmental Management, v. 11, p. 805-821.

Price, I.M., 1977, Environmental contaminants in relation to Canadian wildlife: Transactions of the North American Wildlife Natural Resources Conferences, v. 42, p. 382-396.

Pritt, Jeffrey, and Jones, B.E., eds., 1989, 1990 National Water Quality Laboratory services catalog: U.S. Geological Survey Open-File Report 89-386, variously paged.

Radtke, D.B., Kepner, W.G., and Effertz, R.J., 1988, Reconnaissance investigation of water quality, bottom sediment, and biota associated with irrigation drainage in the lower Colorado River valley, Arizona, California, and Nevada, 1986-87: U.S. Geological Survey WaterResources Investigation Report 88-4002, 77 p.

Rand, G.M. and Petrocelli, S.R., eds., 1985, Fundamentals of aquatic toxicology-Methods and applications: Washington, New York, and London, Hemisphere Publishing Corp. (subsidiary of Harper and Row), $666 \mathrm{p}$.

Ricklefs, R.E., 1973, Ecology: Portland, Oregon, Chiron Press, Inc., 861 p.

Risebrough, R.W., Davis, J., and Anderson, D.W., 1970, Effects of various chlorinated hydrocarbons, in The biological impact of pesticides in the environment, Gillet, J.W., ed., Environmental Health Sciences, Ser. 1, Corvalis, Oregon State University Press, p. 40-53.

Rudd, R.L., and Genelly, R.E., 1956, Pesticides--their use and toxicity in relation to wildlife: California Department of Fish and Game Bulletin 7, 209 p.

Saiki, M.K., 1990, Elemental concentrations in fishes from the Salton Sea, southeastern California: Water, Air, and Soil Pollution, v. 52, p. 41-56.

Salton Sea National Wildlife Refuge, 1990, Colonial nesting bird survey-1990 and summary since 1987, in the files at the refuge.

Schew, W.A., and Collins, C.T., 1990, Age and sex determination in black skimmer chicks: Journal of Field Ornithology, v. 61, no. 2, p. 174-179.

Schlemmer, G., and Welz, B., 1986, Palladium and magnesium nitrates, a more universal modifier for graphite furnace atomic absorption spectrometry: Spectrochimica Acta, v. 41B, no. 11, p. 1157-1165.

Schmitt, C.J., Rubick, M.A., Ludke, J.L, and May, T.W., 1983, Organochlorine residue in freshwater fish, 19761979: National Pesticide Monitoring Program, U.S. Fish and Wildlife Service Resource Publication 152, 62 p.

Schmitt, C.J., Zajicek, J.L., and Peterman, P.H., 1990, National Contaminant Biomonitoring Program--Residues of organochlorine chemicals in U.S. freshwater fish, 1976-1984: Archives of Environmental Contamination and Toxicology, v. 19, p. 748-781.

Schmitt, C.J., Zajicek, J.L., and Ribick, M.A., 1985, National pesticide monitoring program--Residues of organochlorine chemicals in freshwater fish, 1980-81: Archives of Environmental Contamination and Toxicology, v. 14 , p. 225-260. 
Schroeder, R.A., Palawski, D.U., and Skorupa, J.P., 1988, Reconnaissance investigation of water quality, bottom sediment, and biota associated with irrigation drainage in the Tulare Lake bed area, southern San Joaquin Valley, California, 1986-87: U.S. Geological Survey Water-Resources Investigations Report 88-4001, 86 p.

Schroeder, R.A., Rivera, Mick, and others, 1993, Physical, chemical, and biological data for detailed study of irrigation drainage in the Salton Sea area, California, 1988-90: U.S. Geological Survey Open-File Report 93$83,179 \mathrm{p}$.

Schroeder, R.A., Setmire, J.G., and Densmore, J.N., 1991, Use of stable isotopes, tritium, soluble salts, and redoxsensitive elements to distinguish ground water from irrigation water in the Salton Sea basin, in Ritter, W.F., ed., Irrigation and drainage: American Society of Civil Engineers National Irrigation and Drainage Division Conference, Honolulu, Hawaii, July 22-26, Proceedings, p. 524-530.

Schuler, C.A., 1987, Impacts of agricultural drainwater and contaminants on wetlands at Kesterson Reservoir, California: Corvalis, Oregon State University, unpublished M.S. thesis, $136 \mathrm{p}$.

Setmire, J.G., Wolfe, J.C., and Stroud, R.K., 1990, Reconnaissance investigation of water quality, bottom sediment, and biota associated with irrigation drainage in the Salton Sea area, California, 1986-87: U.S. Geological Survey Water-Resources Investigations Report 89-4102, 68 p.

Shacklette, H.T., and Boerngen, J.G., 1984, Element concentrations in soils and other surficial materials of the conterminous United States: U.S. Geological Survey Professional Paper 1270, 105 p.

Sharma, S., and Singh, R., 1983, Selenium in soil, plant, and animal systems: CRC Critical Review and Environmental Control, v. 13, no. 1, p. 23-50.

Singh, M., Singh, N., and Relan, P.S., 1981, Adsorption and desorption of selenate and selenite on different soils: Soil Science, v. 132, p. 134-141.

Skorupa, J.P., and Ohlendorf, H.M., 1991, Contaminants in drainage water and avian risk thresholds, in The economy and management of water and drainage in agriculture, Dinar, A. and Zilberman, D., eds., Norwell, Massachusettes, Kluwer Academic Publishers, p. 345368.

Slavin, W., Carnick, G.R., Manning, D.C., and Pruszkowska, E., 1983, Recent experiences with the stabilized temperature platform furnace and Zeeman background correction. Atomic Spectroscopy, v. 4, no. 3, p. 69-86.

Smith, G.J., and Anders, V.P., 1989, Toxic effects of boron on mallard reproduction: Environmental Toxicology and Chemistry, v. 8, p. 943-950.

Stanley, G.M., 1962, Prehistoric lakes in Salton Sea basin [abs.]: Geological Society of America Annual Meeting, Houston, Texas, p. 149A-150A.

Statgraphics, 1988, Statistical graph system user's guidereference: Rockville, Maryland., Statistical Graphics Corporation, 574 p.
Stebbins, R.C., 1985, A field guide to western reptiles and amphibians: Boston, Houghton Mifflin, 336 p.

Stephens, D.W., Waddell, B., and Miller, J.B., 1988, Reconnaissance investigation of water quality, bottom sediment, and biota associated with irrigation drainage in Middle Green River Basin, Utah, 1986-87: U.S. Geological Survey Water-Resources Investigations Report 88-4011, 70 p.

Stickel, L.F., and Rhodes, L.I., 1970, The thin eggshell problem, in The biological impact of pesticides in the environment, Gillet, J.W., ed., Environmental Health Sciences, Ser. 1, Corvalis, Oregon State University Press, p. 31-35.

Stickel, W.H., Stickel, L.F., and Spann, J.W., 1969, Tissue residues of dieldrin in relation to mortality in birds and mammals: in Miller, M.W., and Berg, G.C., eds., Chemical Fallout: Current research on persistent pesticides, Springfield, Illinois, Charles C. Thomas, p. 174-204.

Sumich, J.L., 1979, Biology of marine life: Dubuque, Iowa, W.C. Brown Co., 348 p.

Switzer, B., Lewin, V., and Wolfe, F.H., 1973, DDE and reproductive success in some Alberta common terns: Canadian Journal of Zoology, v. 51, p. 1081-1086.

Sylvester, M.A., Deason, J.P., Feltz, H.R., and Engberg, R.A., 1989, Preliminary results of the Department of the Interior's irrigation drainage studies: American Society of Civil Engineers, National Irrigation and Drainage Division Conference on Planning Now for Irrigation and Drainage, Lincoln, Nebraska, July 18-21, Proceedings, p. 665-677.

Tinsley, I.J., 1979, Chemical concepts in pollutant behavior: New York, John Wiley, 265 p.

Tod, I.C., and Grismer, M.E., 1988, Drainage efficiency and cracking clay soils: American Society of Agricultural Engineers International Winter Meeting, Chicago, Illinois, December 13-16, 1988, Meeting Presentation Paper 88-2588, $15 \mathrm{p}$.

Tucker, R.K., and Crabtree, D.G., 1970, Handbook of toxicity of pesticides to wildlife: Resource Publication 84, Bureau of Sports Fisheries and Wildlife, Denver Wildlife Research Center: U.S. Government Printing Office, Washington, D.C., 131 p.

Uchida, N., Musachi, T., Katuura, H., Anzai, H., and Nishide, E., 1988, Uptake and fate of p,p'-DDT in carp and tilapia: Nippon Suisaka Gak, v. 54, p. 129-133.

U.S. Department of the Interior and The Resources Agency of California, 1974, Salton Sea project, California: Federal-State Feasibility Report. California Resources Agency, 1985 p.

U.S. Environmental Protection Agency, 1980a, Ambient water quality criteria for DDT: U.S. Environmental Protection Agency 440/5-80-038.

$1980 \mathrm{~b}$, Ambient water quality criteria for chlorinated benzenes: U.S. Environmental Protection Agency 440/5-80-028.

1980c, Ambient water quality criteria for aldrin/ dieldrin: U.S. Environmental Protection Agency 440/580-019. 
U.S. Environmental Protection Agency, 1982, Toxaphene, intent to cancel or restrict registration of pesticides products containing toxaphene; denial of applications for registration of pesticides products containing toxaphene; determination containing the rebuttable presumption against registration; availability of decision document: Federal Register 47(229):53784-53793.

1986, Quality criteria for water: U.S. Environmental Protection Agency 440/5-86-001, 407 p. Update no. 1, 53 p., Update no. 2 (May 1987), approx. 27 p.

1987, Ambient water quality criteria for selenium-1987: U.S. Environmental Protection Agency 440/5-87-006, $39 \mathrm{p}$.

U.S. Fish and Wildlife Service, 1984, Field operations manual for resource contaminant assessment, approx. $495 \mathrm{p}$.

1987, Wildlife of Salton Sea National Wildlife Refuge, California, $14 \mathrm{p}$.

1990a, Patuxent Analytical Control Facility Reference Manual, $119 \mathrm{p}$.

1990b, Final environmental impact statement, endangered species management and protection plan, Naval Weapons Station--Seal Beach, Seal Beach National Wildlife Refuge: U.S. Fish and Wildlife Service and U.S. Navy, 413 p. and appendixes.

1990 c, Effects of irrigation drainwater contaminants on wildlife--summary report: Laurel, Md., Patuxent Wildlife Research Center, July 1990.

Van de Kamp, P.C., 1973, Holocene continental sedimentation in the Salton Basin, California-A reconnaissance: Geological Society of America Bulletin 1984, p. 827 848.

Velinsky, D.J., and Cutter, G.A., 1991, Geochemistry of selenium in a coastal salt marsh, Geochemica et Cosmochimica Acta, v. 55., p. 179-191

Villanueva, E.C., Jennings, R.W., Burse, V.W., and Kimbrough, R.D., 1974, Evidence of chlorodibenzo-pdioxin and chlorodibenzofuran: Journal of Agriculture and Food Chemistry, v. 22, p. 916-917.

Villee, C.A., Walker, W.F., Jr., and Barnes, R.D., 1973, General zoology: Philadelphia, W.B. Saunders Co., $912 \mathrm{p}$.

Vinson, S.B., Boyd, C.E., and Ferguson, D.E., 1963, Resistance to DDT in the mosquitofish, Gambusia affinis: Science, v. 139, p. 217-218.

Vos, J.G., 1971, Toxicity of hexachlorobenzene in Japanese quail with special reference to porphyria, liver damage, reproduction, and tissue residue: Toxicology and Applied Pharmacology, v. 18, 944 p.

Walker, B.W., 1961, The ecology of the Salton Sea, California, in relation to the sportfishery: Fish Bulletin no. 113, State of California, Department of Fish and Game, 204 p.

Welch, A.H., Lico, M.S., and Hughes, J.L., 1988, Arsenic in ground water of the Western United States: Ground Water, v. 26, no. 3, p. 333-347.
Wells, F.C., Jackson, G.A., and Rogers, W.J., 1988, Reconnaissance investigation of water quality, bottom sediment, and biota associated with irrigation drainage in the lower Rio Grande Valley and Laguna Atascosa National Wildlife Refuge, Texas, 1986-87: U.S. Geological Survey Water-Resources Investigations Report 87-4277, 89 p.

Wescot, D.W., 1990, Water and sediment quality survey of selected inland saline lakes: California Regional Water Quality Control Board, Central Valley Region, October 1990, $16 \mathrm{p}$.

White, D.H., Fleming, W.J., and Ensor, K.L., 1988, Pesticide contamination and hatching success of waterbirds in Mississippi: Journal of Wildlife Management, v. 52, no. 4, p. 724-729.

White, D.H., and Krynitsky, A.J., 1986, Wildlife in some areas of New Mexico: Contamination and Toxicology, v. 15, p. $149-157$.

White, D.H., Mitchell, C.A., Kennedy, H.D., Krynitsky, A.J., and Ribick, M.A., 1983, Elevated DDE and toxaphene residues in fishes and birds reflect local contamination in the lower Rio Grande Valley, Texas: Southwest Naturalist, v. 28, p. 325-333.

White, J.R., Hammond, Donald, and Baumgartner, Steve, 1987 , Selenium verification study 1986 , a report to the State Water Resources Control Board: Bay-Delta Project, California Department of Fish and Game, 79 p.

Wiemeyer, S.N., Bunck, C.M., Krynitsky, A.J., 1988, Organochlorine pesticides, polychlorinated biphenyls and mercury in osprey eggs, 1970-79, and their relationships to shell thinning and productivity: Archives of Environmental Contamination and Toxicology, v. 17, p. 767-787.

Wiemeyer, S.N., and Porter, R.D., 1970, DDE thins eggshells of captive American kestrels: Nature, v. 227, p. 737-738.

Wiemeyer, S.N., Spann, J.W., Bunck, C.M., and Krynitsky, A.J., 1989, Effects of Kelthane ${ }^{\circledR}$ on reproduction of captive eastern screech-owls: Environmental Toxicology and Chemistry, v. 8, p. 903-913.

Winger, P.V., Sieckman, C., May, T.W., and Johnson, W.W., 1984, Residues of organochlorine insecticides, polychlorinated biphenyls, and heavy metals in biota from Apalachicola River, Florida, 1978: Journal of Association of Analytical Chemists, v. 67, p. 325-333.

Young, D.R., 1984, Methods of evaluating pollutant biomagnification in marine ecosystems in H.H. White, ed., Concepts in Marine Pollution: College Park, Maryland, Maryland Sea Grant, p. 261-278.

Zell, M., and Ballschmiter, K., 1980, Baseline studies of the global pollution--II. Global occurrence of hexachlorobenzene (HCB) and polychlorocamphenes (toxaphene) (PCC) in biological samples: Fresenius' Zeitschrift för Analytische Chemie, v. 300, p. 387-402.

Zenkevich, L.A., 1951, The seas of the USSR, their fauna and flora: Moscow, Pravda, p. 314-338.

Zimmerman, R.P., 1981, Soil survey of Imperial County, California, Imperial Valley area: U.S. Department of Agriculture, Soil Conservation Service, 112 p. 